\title{
Corporate Social Responsibility within Social Media-Stakeholder Relations Strategies: Case of Turkish Stock Exchange Companies
}

\author{
Ezgi Yildirim Saatci ${ }^{1}$, Işıl Çobanlı Erdönmez ${ }^{2}$ \\ ${ }^{1}$ Department of Management, Okan University, Akfirat İstanbul, Turkey \\ ${ }^{2}$ Social Entrepreneurship Research Center, Okan University, Akfirat İstanbul, Turkey \\ Correspondence: Ezgi Yildirim Saatci, Department of Management, Okan University, Akfirat İstanbul, Turkey
}

$\begin{array}{lc}\text { Received: August 24, } 2015 & \text { Accepted: September 10, } 2015 \text { Online Published: September 18, } 2015 \\ \text { doi:10.11114/bms.v2i1.1092 } & \text { URL: http://dx.doi.org/10.11114/bms.v2i1.1092 }\end{array}$

\begin{abstract}
Emergence and dominance of internet has changed the rules of the business world. Customer centric strategies became customer participated actions with the rise of social networks where all functional strategies of the firms are continuously being reshaped according to customer values. At the same time, concerns of customers as the buyers in terms of cost and quality are also backed up with their concerns as a member of the society where the organizations have direct impact on, which can give a clear explanation for the enhanced corporate social responsibility movement of the last decade. Philanthropic act of organizations are also considered as the fifth $\mathrm{P}$ of marketing which is also channeled through new media such as Face book, YouTube, LinkedIn, Twitter and YouTube. This paper intends to investigate 53 Turkish Holding companies which are register to Turkish Capital Market Board -and therefore, have to declare their social responsibility projects according to corporate governance rules- with an aim to contrast these projects' prevalence in the social media and strategic use of marketing elements accordingly to frame the Turkish perspective.
\end{abstract}

Keywords: CSR, Strategy, Marketing, Social Media, Turkish Holding Companies

\section{Introduction}

In the aggressive and customer centric business arena, companies are incessantly searching for distinctive competitive advantages to ensure their sustainability. The emergence and dominance of internet has also changed the rules of the game underlying the importance of sustainable profitability more than ever. As Porter quoted in his Harvard Business Review article named Strategy and Internet “...Because the Internet tends to weaken industry profitability without providing proprietary operational advantages, it is more important than ever for companies to distinguish themselves through strategy. The winners will be those that view the Internet as a complement to, not a cannibal of, traditional ways of competing" (Porter: 2001 p. 79), internet based marketing activities play a leading role to obtain the strategic superiorities explaining the shift of 4Ps (price, place, product, promotion) of marketing to the 4Cs (cost, convenience, consumer, communication). Moreover, the communication part has also changed with the emergence of social media where social networks create an effective channel of imposing the strategies, having lean feedbacks and reshaping the strategies of organizations.

On the other hand, transparency and elimination of information asymmetry also force organizations to place customer value at the center of all strategic moves and routine activities in which what customer assess crucial becomes the essence of organizational offerings. Apart from the price, quality, prestige and other attributes, customers' own values also began to be considered as a variable of interest for the sake of sustainable profitability of customer centric strategies. According to Schwartz "Values were crucial for explaining social and personal organization and change. Values are used to characterize societies and individuals, to trace change over time, and to explain the motivational bases of attitudes and behavior." (Schwartz 2006). Among the values of customers, benevolence weight a substantial amount of consideration that poses a perspective to explain the amounting importance of "Corporate Social Responsibility (CSR) and "Cause-Related Marketing (CRM)" while other perspectives are escalating pressure to take responsibility for the effects of their corporate conduct on society (Macleod, 2001; Mohr et al., 2001, Maignan and Ralston, 2002).

In this paper, it is aimed to investigate CSR and CRM as a $5^{\text {th }} \mathrm{P}$ of marketing (Philanthropy) in conjunction with the $4^{\text {th }}$ 
C "Communication" through social networks such as Facebook, Twitter, LinkedIn, Twitter and YouTube in the context of Turkish Group Companies enlisted in the stock-exchange and registered in Capital Market Board of Turkey. It aims to contribute to the literature that scrutinize the relation of organizational philanthropic act with consumer choice and decision (Webb and Mohr, 1998; Barone et al., 2000), and consumer perception toward the CSR program in specific and towards the companies that slot in such a marketing agenda (Webb and Mohr, 1998,Lafferty and Goldsmith, 2005).

In the first part, literature review of $5^{\text {th }} \mathrm{P}$ of marketing: philanthropic act of companies and the rise of social media for stakeholder relations are discussed. In the research part, hypothesis, sample and methodology are discussed followed by the results and concluding remarks for future researches.

\section{Literature Review}

\subsection{Fifth P of Marketing: Philanthropic act of Companies-CSR}

As organizations grew larger and larger by the end of 1950, the fundamental questions concerning moral duties and responsibilities of corporations raised also. By 1970s, In USA, Committee for Economic Development published a memorandum in which they have defined responsibilities of organizations with three layered circle. Inner circle was represented as economic functions, duties and responsibilities, whereas the middle circle was seen as responsibility of performing business in accordance with social values and priorities and the utmost circle was outlined as responsibilities concerning the larger-social environment (Edward Mason, 1974).

The awareness created has also shifted attentions from social responsibility to social responsiveness emphasizing corporate proactive obligation, action, as well as the implementation of a social role. (Carroll, Archie B., 1991) Motives behind the organizational social responsiveness of companies have derived from different sources as perceived moral or religious obligations, philanthropic considerations, or economic self-interest and even further as sustainable strategic management act (Parnell 2008; Weber, 2008).

At the early stages, organizational course of responsible act was not mandatory -even to some extent assumed to be cost center- consuming corporate resources. Economist Milton Friedman is most known for his argument "from a purely economic perspective that business' only responsibility referred to the profitable use of resources within the boundaries of the laws of those countries in which they work. Since only people could have social responsibilities, the only social responsibility of business was to increase its profits" (Friedman, 2007 p4) forms the basis of shareholder theory. From the same point of view social responsibility was also viewed as an investment by corporations (Stroup and Neubert 1987) with an ultimate goal of profit maximizing to their shareholders through corporate image.

On the other hand, Shareholder theories of management evolved with property rights theory and contractual theory -based on the pillar works of Frédéric Bastiat, Henry George, Garrett Hardin, John Locke, David Ricardo Jean-Jacques Rousseau, Adam Smith- representing bundle of rights as for the use of good, for the income from the good, and for the transfer of the good to others underlining "others" and "interaction. (Jongwook Kim1,* and Joseph T. Mahoney, 2005) to the modern era concept of Stakeholder theory where- shareholders who once were assumed to be the only interest group for organizations has been replaced with stakeholders including employees, suppliers, customers, investors and any interacting group at large. - (Donald and Preston, 1995) Carroll's pyramid of corporate social responsibility also advocates stakeholder concept and embraces ethical dimensions as presented in Figure 1 and evaluated for the stages of Corporate Social Responsibility in Figure 2.

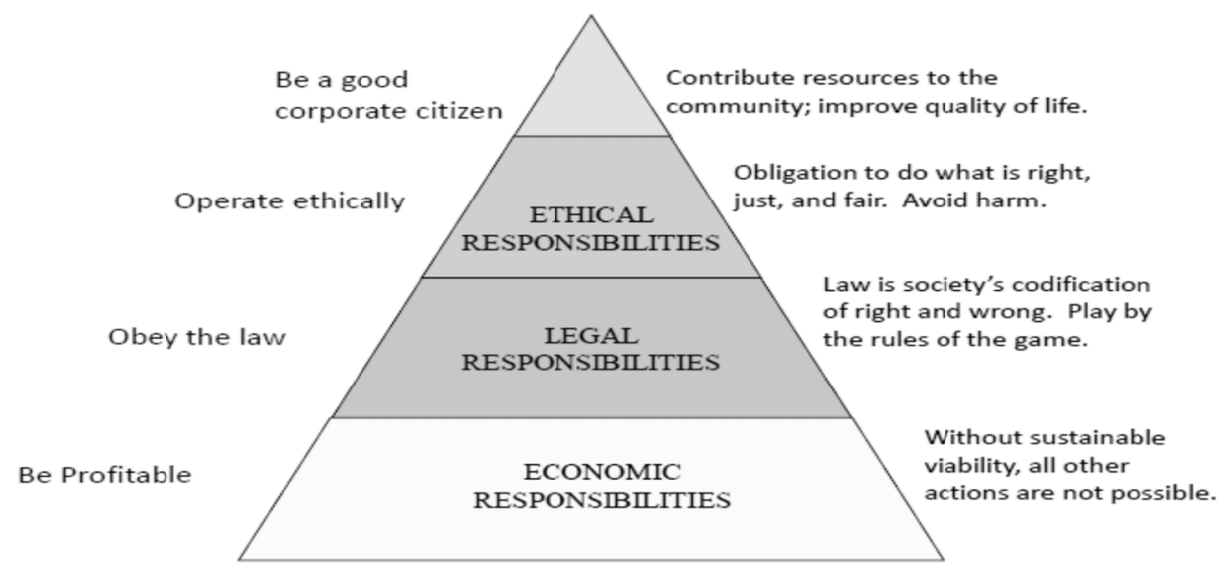

Figure 1. Philanthropic Responsibilities

Source: The Pyramid of Corporate Social Responsibility (Carroll, 1991) 


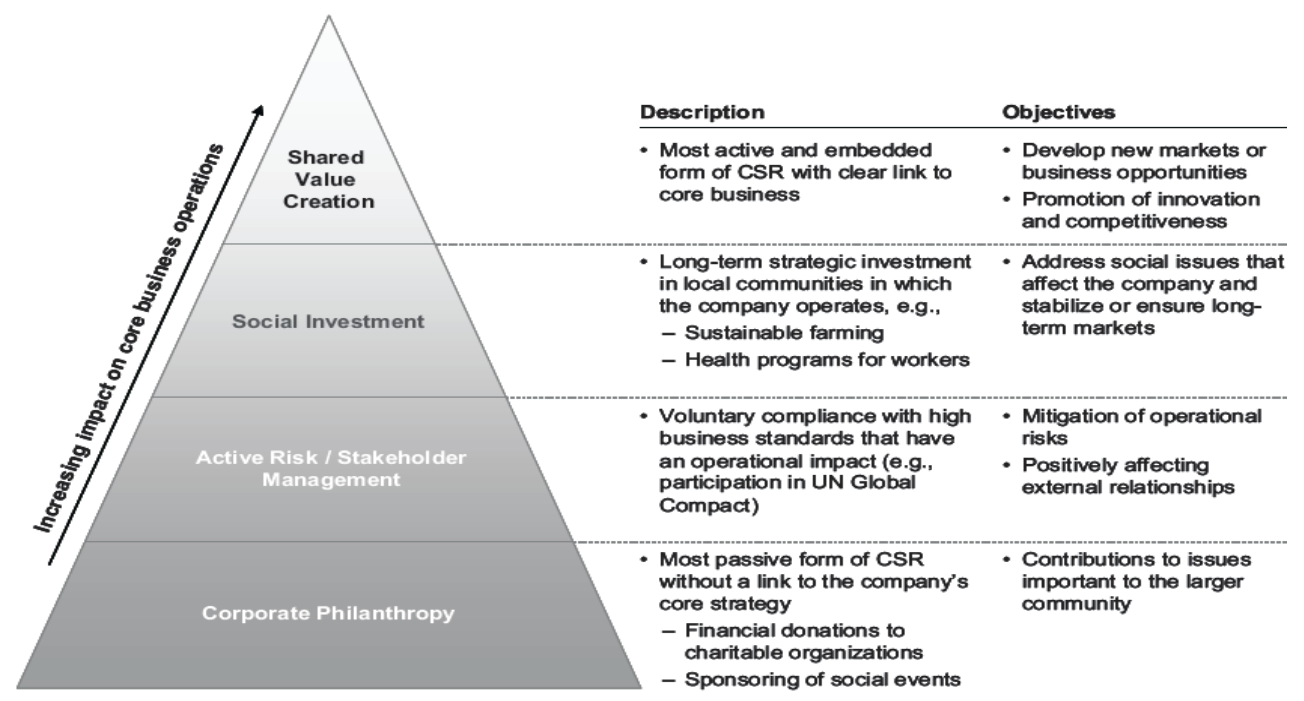

Figure 2. Corporate Social Responsibility Pyramid.

Source: Mapping the Field (Humberg, 2103 p 23)

In 1980s and 1990s, organizations began to comprehend that, for organizational survival and strategic/competitive advantage; they must change their perspectives from doing good to doing good for the good (Rosenthal 1985; Grahn, Hannaford, and Laverty 1987) and as corporate social responsibility became an important source of linkage between core business activities and corporate philanthropy, marketing function of businesses started to play a leading role and alerted the concept for its strategic use such as

- To be visible in a pleasant way to enhanced corporate image (Josephson 1984; Maier 1985)

- To broaden customer base with new market segments and geographic markets, (Higgins 1986; Mescon and Tilson 1987; Chaudhuri and Holbrook, 2001).

- To create brand awareness and recognition (Rosenfeld 1985; Scott 1986; Dick and Basu, 1994; Sen and Bhattacharya, 2001),

- To promote upsell, crossell and repeated sells (Tinsdall, 1982; Wall 1984; Williams, 1986) and

- To enhance brand loyalty with premium prices increased market share (Aaker, 1996; Kapferer, 1997; Chaudhuri and Holbrook, 2001)

In 2000s, Famous marketing expert Philip Kotler proposed societal marketing concept that combines consumers' want and needs with company's want and needs along within a larger framework of society's long-term interest attracted more and more interest. In his Harvard business Review article "What consumerism means for marketers", Kotler (1972) questioned conventional methods of marketing with four Ps (product, price, place, and promotion) and integrated responsible act of organizations into the "product" element. Kotler's concept of societal marketing propose that for the well-being of society at large, the deficient products (which bring neither long-run or short term benefits) should be removed from the market, pleasing (which bring a high level of immediate satisfaction, but can ground negative effect to the society in the long run) and salutary products (which bring low short term satisfaction, but advantageous outcomes for the society in the long run) should be evolved to obtain desirable products that combine immediate and high level satisfaction with long-run societal and environmental benefits.

In conjunction with this concept in 2000s philanthropy and cause related marketing concept has gained importance and considered to be $5^{\text {th }} \mathrm{P}$ of marketing by many experts. This became more significant with the announcements of monetary terms involved in this area. According to the Cone Millennial Cause Study in 2006, 89\% of Americans (aged 13 to 25) would switch from one brand to another brand of a comparable product (and price) if the latter brand was associated with "good cause" (p.52) which enlightens the reason for the increase in corporate spending on cause marketing from \$1.11 billion in 2005 to \$1.57 billion in 2009 (Armstrong, J. Scott; Green, Kesten C., 2012). On the other hand, the rise of social media also boosted the corporate social responsibility and cause related marketing activities as discussed in the next part of the paper.

\subsection{Rise of Social Media for Stakeholder Relations}

After commercialization of Internet Technologies, World Wide Web has also started to affect the society by the extension of the consciousness. For the last decade social media became a follow-up of mass media. First of all, social networks like Friendster, MySpace, and LinkedIn appeared in the beginning of 2000s. Then Facebook and Twitter repeatedly showed themselves in 2004 and 2006. Within these social areas, people started to join groups or pages 
democratically and found mutual sharing facilities. Blogs, video and picture sharing sites, podcasts and e-mailing quickly became and set new standards for the main social media channels. But, the major rule-of-the-game changing advances were obtained with social networks that have a massive interactivity features than can be used by everyone, where the context can change within seconds and they can grow bigger with their follower numbers.

In 2015 the rates and usage of these new media are majorly dominated by Facebook 92\%; Twitter 84\%; LinkedIn 71\%; Blogs 68\%; YouTube 56\%; Forums 24\%; Foursquare 17\%; MySpace: 6\%; Social Bookmarking 26\% and time spent on is shown in Figure 3.

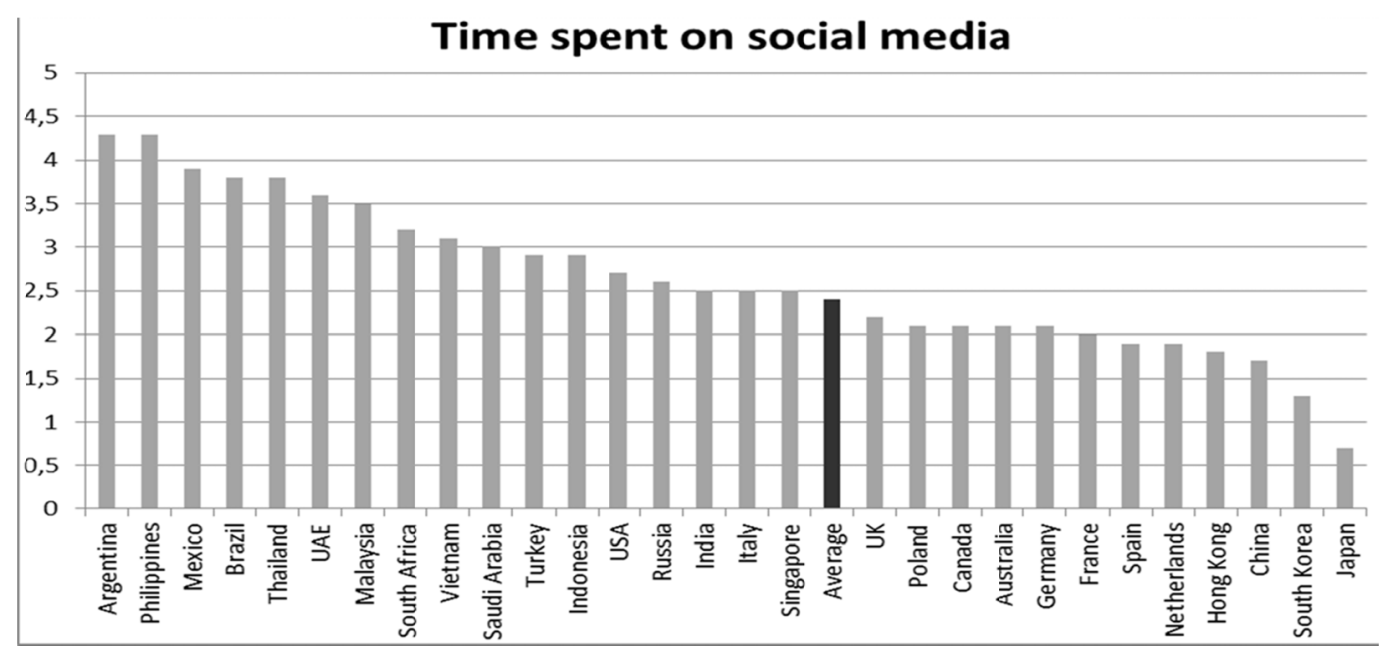

Figure 3. Time spent on social media

\section{Source: Social Media Trends 2015, Research, Rival IQ}

The main difference between traditional media and the new media is the format. The new format is about interactive multimedia. Because they rely on the digital encoding system, it's possible to transfer large amounts of information at the same time and the user have the possibility to be found in the immediate recycling. So that we can say that the information has passed from rectilinear transmission to hyper textuality (Binark: 2015). The new media is a multimedia format with indicators and symbol systems, so the communication types are different types of data in a single tool (Van Dijk, 2004: 146). In addition to this, the high storage capacity of the new media supports user selectivity. These easy uses of practices make the users join the communication circle easily.

Besides; another difference between the audience commodity for traditional mass media and for the internet is that, in the latter case, the users are also content producers who engage in permanent creative activity, communication, community building, and content-production. In the case of Facebook, the audience commodity is an internet consumption related commodity (Fuchs, 146). Facebook surveillance creates detailed user profiles so that advertising clients know and can target the personal interests and online behaviors of the users. The language of social media content has an intimate and reliable language so this looks familiar to non-professional people. At this point, marketers started to learn this new language. These features are:

-Participation: It's democratic for everyone who has Internet

-Clarity: Everyone can see the communication channels

-Colloquy: Dialogues are continuous

-Community: Minimal social groups can appear

-Interconnection: People can reach each other through network services (Stelzner, 2011).

In the light of above stated differences, all parties that surround organizations have shifted their roles in the form of stakeholder relationships in a more interactive manner. As McLuhan (1994) claims "while bringing social and political functions together in a flash blowup, electric speed heightened human awareness of responsibility to an intense degree" (p.6). On the other hand, Kumar (2004) referees from Toffler that, "new information technologies give a form to new life styles. At areas like work, game, education, family relations and in emotional structures; In a nutshell, parallel to new technologies, beyond the changes in communication styles, also people of the society -if they are ready-can also change the rules." (p. 54).

As Manual Castells (2000) argues "networks constitute the new social morphology of our societies; the expansion of a networking logic critically modifies the operation and outcomes in processes of experience, production, culture and 
power" (p.18). As referred from McLuhan; "Increased speed of communication and the ability of people to read about, spread, and react to global news quickly, forces us to become more involved with one another from various social groups and countries around the world and to be more aware of our global responsibilities" (McLuhan: 1994, 6).

\title{
3. Research
}

For the research's aim - to investigate CSR and CRM as a $5^{\text {th }} \mathrm{P}$ of marketing (Philanthropy) in conjunction with the $4^{\text {th }}$ C "Communication" through social networks such as Facebook, Twitter, LinkedIn, Twitter and YouTube in the context of Turkish Group Companies enlisted in the stock-exchange and registered in Capital Market Board of Turkeyintensive secondary data collection was done both online and offline.

\subsection{Sample}

There are 349 companies listed in Istanbul Stock Exchange and regulated under the regulations of Turkish Capital Board. These companies are obliged to handle Corporate Governance Report and according to transparency act, they have to publish it online. For the convenience and coverage of the sampling, convenience sampling was used and holding companies were selected with a total of 202 representing the $57,87 \%$ of the population. 53 holding companies selected have an average of 6 distinctive enterprises each (with a maximum of 25 and minimum of 2 enterprises) and their descriptive statistics are presented below:

Table 1. Sample Holdings Profile

\begin{tabular}{cc}
\hline Total Number of Companies & Number of Holdings \\
\hline 2-5 Companies Under Holding Umbrella & 29 \\
6-10 Companies Under Holding Umbrella & 13 \\
11-15 Companies Under Holding Umbrella & 5 \\
16-20 Companies Under Holding Umbrella & 4 \\
21 and + Companies Under Holding Umbrella & 2 \\
\hline TOTAL & $\mathbf{5 3}$ \\
\hline
\end{tabular}

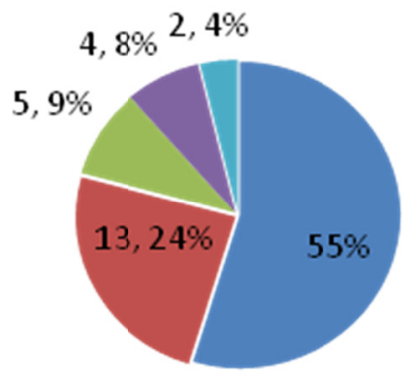

\author{
2-5 Companies Under Holding Umbrella \\ 6-10 Companies Under Holding Umbrella \\ 11-15 Companies Under Holding Umbrella \\ 16-20 Companies Under Holding Umbrella \\ 21 and + Companies Under Holding Umbrella
}

Figure 4. Sample Holdings' Companies Number

Source: Own draft based on Capital Market Board http://www.spk.gov.tr/

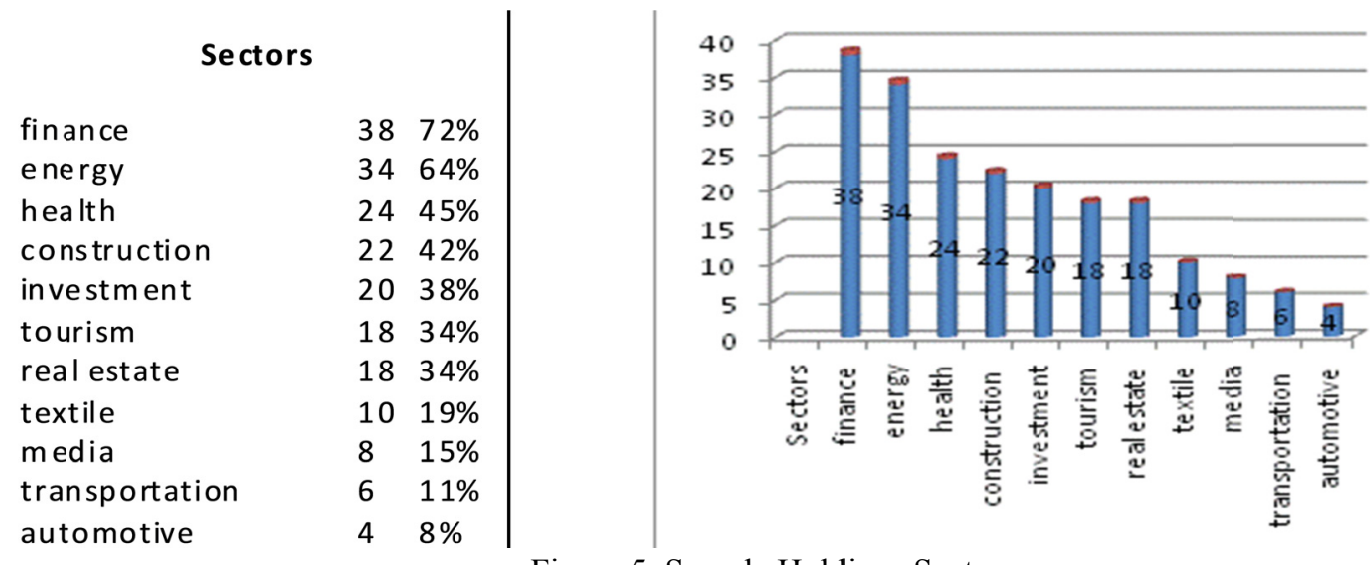

Figure 5. Sample Holdings Sectors

Source: Own draft based on Capital Market Board http:/www.spk.gov.tr/ 


\subsection{Procedure, Measures and Data Analysis}

This research has been handled with a secondary-data collection method to measure the quantitative data available for the public use. A survey sheet has been created in SPPS 21 and marked for each of the items namely: Number of companies, Facebook presence, Twitter presence, LinkedIn presence, YouTube presence, Facebook members, Twitter followers, LinkedIn followers, YouTube members, major sectors of operation, name of the CSR, CSR related problem area, Facebook presence for CSR project, twitter presence for CSR project, LinkedIn presence for CSR project, YouTube for CSR project, Facebook members of CSR project, Twitter followers of CSR project, LinkedIn followers of CSR project, and YouTube followers of CSR project.

The starting point of the analysis was official web sites of all the companies selected in the sample. All of them have been examined by detail and have been checked for any announcement related to CSR activities. For those who have CSR project, major sectors of operation, name of the CSR, and their own working fields and web sites have further investigated thoroughly. Announced projects were further checked for their own web-site presence. Furthermore, the web search with the name of the company and name of the project were conducted separately for the purpose of confirming the information announced and of backing up with additional announcements. Facebook presence, Twitter presence, LinkedIn presence, YouTube presences of each company and each of the projects have further been checked by looking at the formal main pages of these social media areas according to the publicized presence and number of members/followers. For each of the project, member/follower number had also been written down and crosschecked by the page to the working sheet. The analysis took 4 months and procedurally was being updated during that time period and their results are presented in the following part.

\subsection{Results}

The total number of CSR projects that were declared by 53 holding companies and covered in social media is amounted to 234 with an average of 4.03 Among 53 companies, 29 of them have announced 1 to 5 CSR Projects for the last five years. 13 of them with a maximum number of 6 to 10 CSR Projects. Number of companies drop when the CSR Project number reaches 11-15 with 5 holding companies and 15-20 with 4 holding companies. There are only 2 holding companies with more than 20 announced CSR Projects over the last 5 years period with an average of 4.2 CSR project per year as presented below.

Table 2. CSR Projects by Holdings Companies between 2010-2015

\begin{tabular}{cc}
\hline Total Number of CSR Campaign by Organization & Total Number Holding Companies \\
\hline 1-5 CSR Campaigns & 29 \\
5-10 CSR Campaigns & 13 \\
$11-15$ CSR Campaigns & 5 \\
16-20 CSR Campaigns & 4 \\
21 and + CSR Campaigns & 2 \\
\hline
\end{tabular}

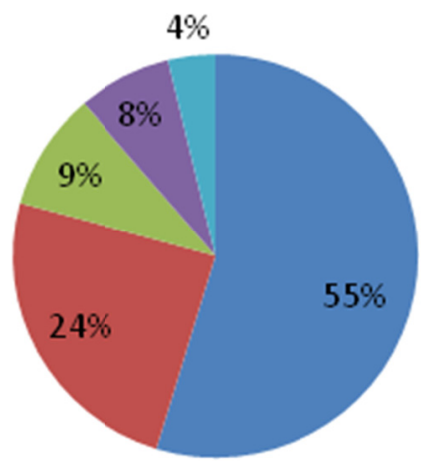

\section{1-5 CSR Campaigns}

5-10 CSR Campaigns

11-15 CSR Campaigns

-16-20 CSR Campaigns

- 21 and + CSR Campaigns

Figure 6. Percentage of Holding Companies with CSR Project Numbers

\section{Source: Own Draft}

In parallel to above stated numbers, the related area of CSR Projects with subsequent total number of projects and organizational involvement is presented below. Out of 234 project, $45 \%$ of companies are involved in 48 Education related CSR activities and projects. The second order goes to environmental projects with a total number of 38 compromising $34 \%$ of the holding companies. Third area is culture and arts CSR projects with a total number of 36 followed by both gender and youth related projects with $25 \%$ involvement of holding companies each. The next areas and relevant numbers are Children with 18 projects, Health with 18 projects, Technology with 14 projects and Sport with 10 projects. 
Table 3. Area of CSR Projects by Holdings Companies Between 2010-2015

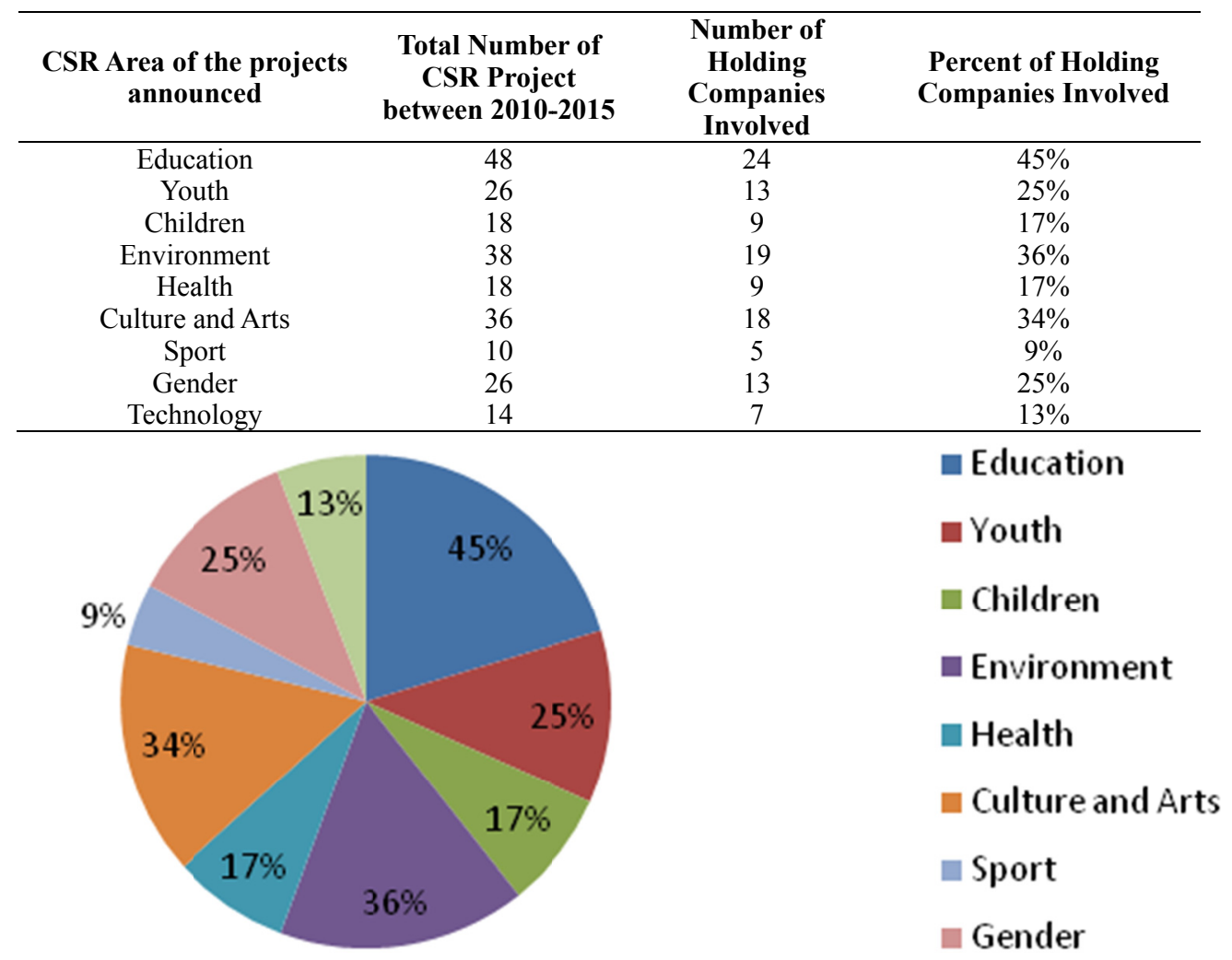

Figure 7. Percentage of Holding Companies with CSR Project Areas

Source: Own Draft

On the other hand, the social media coverage of holdings, their companies and CSR activities show Facebook preference over LinkedIn, twitter and YouTube respectively.

Table 4. Presence of Holdings Companies in Social Media

\begin{tabular}{lcc}
\hline \multicolumn{1}{c}{ Presence } & Number of Holdings & Percent of Presence \\
\hline Twitter & 22 & $41,51 \%$ \\
Facebook & 39 & $73,58 \%$ \\
Linkedin & 35 & $66,04 \%$ \\
Youtube & 14 & $26,42 \%$ \\
\hline \multicolumn{2}{l}{} \\
\hline
\end{tabular}

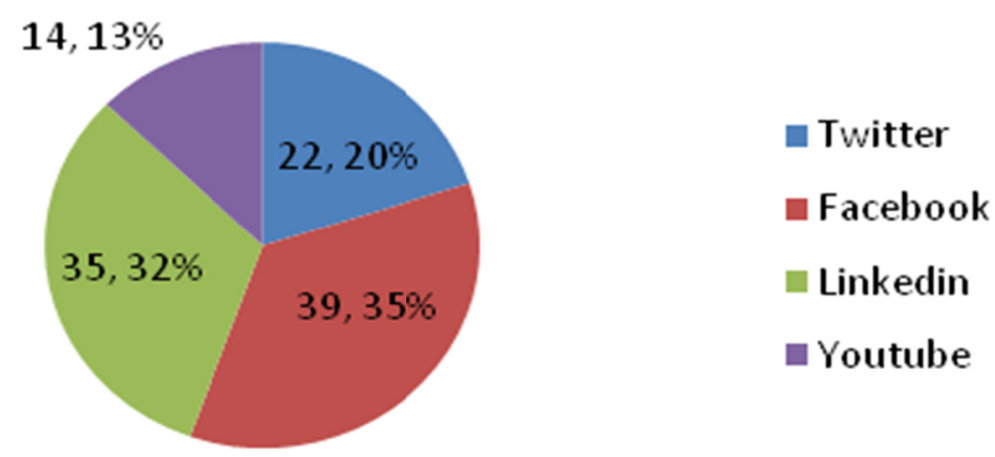

Figure 8. Percent of Holdings' Presence in Social Media

Out of 234 projects, 143 of them are placed in Facebook, 87 of them in Twitter, 72 of them in LinkedIn and only 32 of them in YouTube with maximum coverage in social media is $61 \%$. 
Table 5. Presence of Holdings' CSR Activities in Social Media

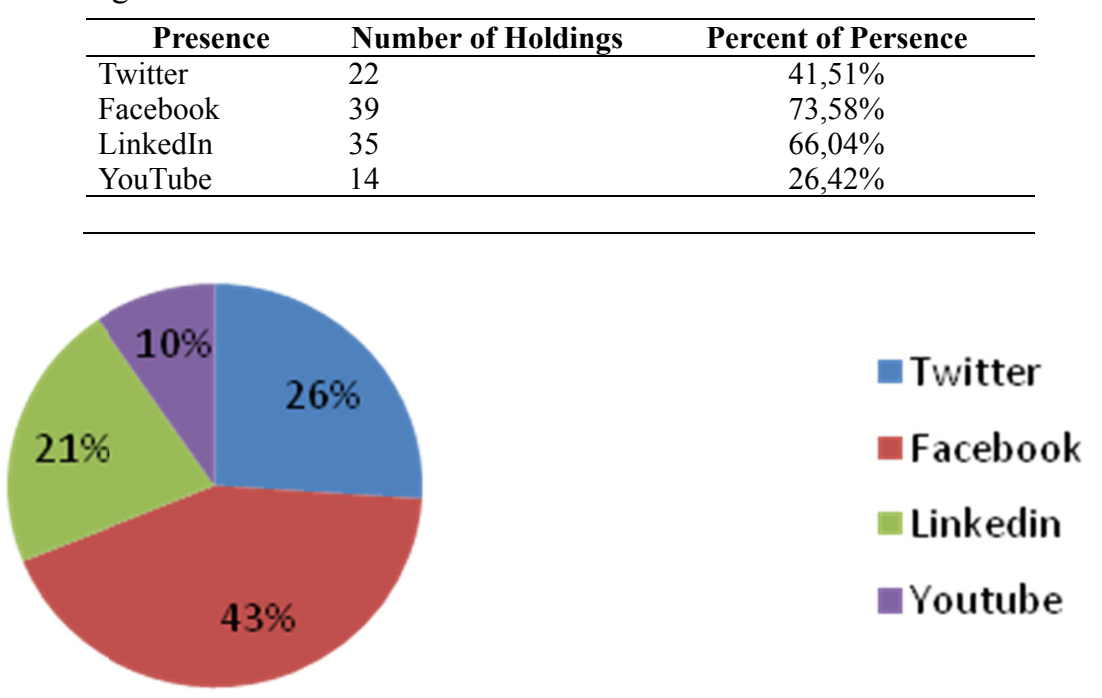

Figure 9. Percent of Holdings' CSR Presence in Social Media

Source: Own Draft

Apart from their presence, the number of followers/members for each of the holdings' companies and CSR projects are as follow to signify the effectiveness of their being within social media and their usage of CSR activities as stakeholder relation medium.

Table 6. Number of Members/Followers of Holdings' in Social Media

\begin{tabular}{cccccccc}
\hline $\begin{array}{c}\text { Number of } \\
\text { Facebook } \\
\text { Members }\end{array}$ & $\begin{array}{c}\text { Number } \\
\text { of } \\
\text { Holdings }\end{array}$ & $\begin{array}{c}\text { Number of } \\
\text { Twitter } \\
\text { Followers }\end{array}$ & $\begin{array}{c}\text { Number } \\
\text { of } \\
\text { Holdings }\end{array}$ & $\begin{array}{c}\text { Number of } \\
\text { LinkedIn } \\
\text { Members }\end{array}$ & $\begin{array}{c}\text { Number of } \\
\text { Holdings }\end{array}$ & $\begin{array}{c}\text { Number } \\
\text { of } \\
\text { Holdings }\end{array}$ \\
\hline $1-999$ & 8 & $1-999$ & 4 & $1-999$ & 10 & $1-99$ & 5 \\
$1000-9999$ & 18 & $1000-9999$ & 7 & $1000-9999$ & 16 & $100-499$ & 4 \\
$10000-99999$ & 7 & $10000-99999$ & 6 & $\begin{array}{c}10000 \text { and } \\
\text { above }\end{array}$ & 9 & $500-999$ & 3 \\
100000 and & 6 & $\begin{array}{c}100000 \text { and } \\
\text { above }\end{array}$ & above & 5 & & & 1000 and \\
above & 2 & 14 \\
\hline
\end{tabular}

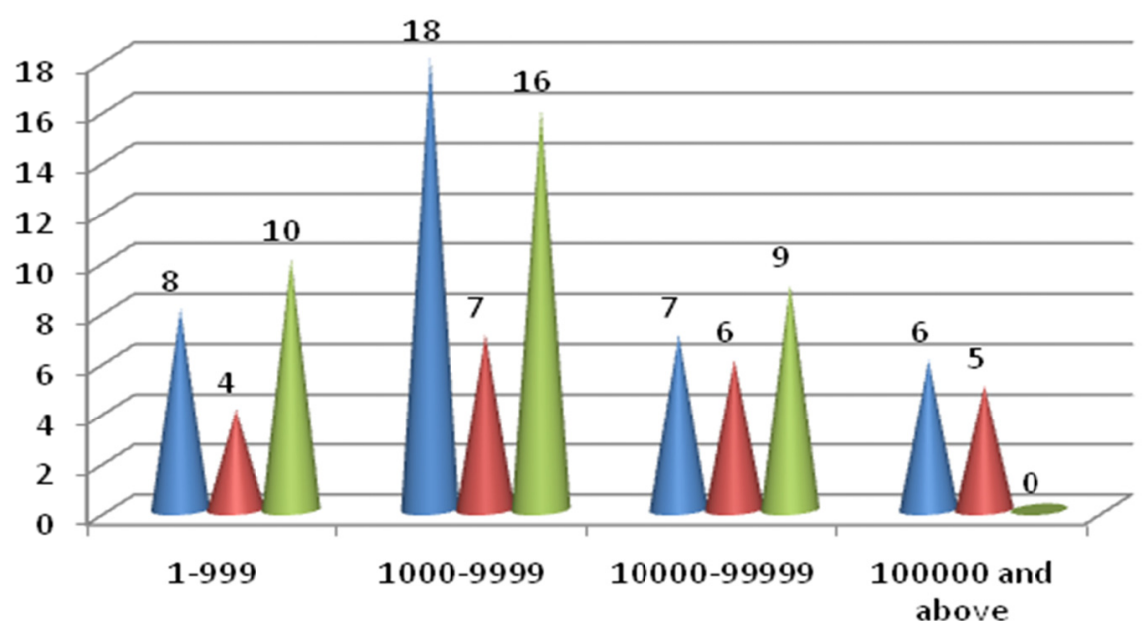

$$
\begin{aligned}
& \text { w Facebook } \\
& \text { w Twitter } \\
& \text { winkedin }
\end{aligned}
$$

Figure 10. Comparative Number of Members/Followers of Holdings' in Social Media

Source: Own Draft

\subsection{Concluding Remarks}

When we look at the results, it shows that $72 \%$ of the 53 companies which are evaluated; are in finance area. $64 \%$ of them are in energy area, $45 \%$ of them are in health area, $42 \%$ of them are in construction, $38 \%$ of them are in investment area. Tourism and real estate occupy place by $34 \%$ and the other ones confect $20 \%$ of the rest. 
There are 234 CSR projects in total. Each company falls in to one. Almost half of them are about education with $45 \%$. After that; $36 \%$ of them are about environment, $34 \%$ of them are about culture and arts, $25 \%$ of them are about youth and gender, $17 \%$ of them are about children and health, 13\% is technology and 9\% is about sports.

If we take a look at North America, most developed policies are in the areas of child labor, supply chain inspections and local community development generally. (Welford, 46) There seem to be more relevant policies in Japan, Korea and Singapore like fair wage, working weeks and overtime structures. (Welford, 45)

In Asia, CSR projects and campaigns seem to follow new movements in the West (Mohan 2001; Moon 2002). "However, while the main concept of environmental management, social responsibility and sustainable development is the same, there are very different priorities in countries where norms, values and economic development differ." (Rock2002; Ruud 2002) In Asia there are serious differences between different countries. Companies reflect what is important among stakeholders in their own countries mostly and can also be affected by local culture. (Welford, 51) In addition to this, at Turkey most efficient CSR projects are seem to be related in the areas of education; this can be the outcome point of a social problem. And for those with the lowest percent are about sports and technology; so that this shows us that; these companies do not work on the projects that society doesn't interested in.

The total number of CSR projects that were declared by 53 holding companies and covered in social media in Turkey is amounted to 234 with an average of 4.03 for the last five years. When we look at the data of 2006 in United States, there were 230 companies that issued CSR reports. While in 1991 only two companies issued CSR reports, so the compound annual growth rate (CAGR) of CSR reporting from 1991 through 2006 is 37\% in USA. (Cecil, 46) The number of companies surveyed in North America, India and Europe is, 450 in total at the year of 2004. So it is obvious that, the number of the CSR projects in Turkey between the years 2010-2015 is at the lower level of the total of these countries which evaluated in 2004.

When we look at the presence of companies in social media, the most popular network type is Facebook with 73,58\%, and after LinkedIn comes with $66,04 \%$. Follows them Twitter comes with $41,51 \%$ and last one is YouTube with $26,42 \%$. So this shows us that companies represent themselves most efficient in Facebook and LinkedIn because these are about official following and have commercial attitudes. Twitter and YouTube can defined as more instantaneous.

The most popular social communication network within these CSR projects; is Facebook with 143 presences. Follow that, Twitter comes with 87 presences. After that with 72 presences within the CSR projects shows LinkedIn. And finally YouTube has 32 presences within these projects. This shows us that when people wants to identify themselves within the CSR projects they are active in Twitter not with LinkedIn after Facebook because LinkedIn is much about the company itself but Twitter is more spurt and easy using.

It is obvious that company strategies can't be discussed without profit. The CSR projects they have been doing are parallel to this. Right now the most popular form to announce these projects; is social media. So they can become visible in a pleasant way to enhance their corporate image. As Gurin (1987) tells, these areas are target popular, risk-free, high visibility causes. So that members can be converted into consumers easily within these visible social presences. The strong image of being valuable for the company; shows itself within these corporate perceptions. And the perception can easily be shaped by communication channels.

The biggest 5 companies in Turkey have the most favorite and popular CSR pages in Turkey. This is a two side relationship because they invested once a lot and now they pull toward the people who have possibility to interest with their projects and investments. So they try to back the right horse. Especially for the most popular project campaigns, it is easy to create and spread/circulate the idea of it, from web channels so that there can doubled in minutes.

Stakeholders can easily connect with their expectant customers, partners or fellows through CSR projects or projects using online connections. Specifying the target groups from the social pages is easy because people's interests and likes/choices are open. What time do they spent on which topics at Facebook or what groups are they belong in LinkedIn pages can easily found. For example, if general percent of the CSR projects focus on education, probably there's a reason about the society in Turkey. Technologic issues are at the lower levels at the project related areas maybe this is because of the idea related with the interest points in Turkey. This can be a discussion point of a new research area for the future.

\section{References}

Aaker, D. (1996). Building Strong Brands. New York: The Free Press

Akar, E. (2010). Sosyal Medya Pazarlamasl: Sosyal Webde Pazarlama Stratejleri. Ankara: Efil Yayınevi.

Armstrong, J. S., \& Green, K. C. (2012). Effects of corporate social responsibility and irresponsibility policies. MPRA Paper. Germany: University Library of Munich, 43007. http://dx.doi.org/10.1016/j.jbusres.2013.02.014 
Barone, M. J., Miyazaki, A. D., \& Taylor, K. A. (2000). The influence of cause-related marketing on consumer choice: does one good turn deserve another? Journal of the Academy of Marketing Science, 28(2), 248-262. http://dx.doi.org/10.1177/0092070300282006

Batı, U. (2013). Stratejik Marka Yönetimi (Strategic Brand Management). İstanbul: The Brand Age

Binark, M. (2015). Yeni Medyayl Nasıl Tanımlarız? January $21^{\text {st }}$, 2015 https://yenimedya.wordpress.com/calismalar/

Breakenridge, D., \& Solis, B. (2009). Putting the Public Back in Public Relations: How Social Media is Reinventing the Aging Business of PR. New Jersey: Pearson Education, Inc. Publishing as FT Press Upper Saddle River

Carroll, A. B. (1991). The Pyramid of Corporate Social Responsibility: Toward the Moral Management of Organizational Stakeholders. Business Horizons, 34(4). http://dx.doi.org/10.1016/0007-6813(91)90005-G

Castells, M. (2000). The Rise of the Network Society: Economy, Society and Culture. UK: Blackwell Publishing Ltd.

Castells, M. (2013). The Network Society: From Knowledge to Policy. Washington, DC: Center for Transatlantic Relations, Jhu-Sais

Cecil, L. (2010). Corporate Social Responsibility Reporting in the United States. McNair Scholars Research Journal, 1(1), Article 6.

Chaudhuri, A., \& Holbrook, M. B. (2001). The chain of Effects from Brand trust and Brand affect to Brand Performance: The role of Brand Royalty. Journal of Marketing, 65(2), ABI/INFORM Global

Dick, A., \& Basu, K. (1994). Customer loyalty: towards an integrated framework. Journal of the Academy of Marketing Science, 22(2), 99-113. http://dx.doi.org/10.1177/0092070394222001

Donaldson, T., \& Preston, L. E. (1995). The Stakeholder theory of the Corporation: Concepts, Evidence, and Implications. Academy of Management Review, 20(1), 65-91.

Friedman, M. (1970). The Social Responsibility of Business is to Increase its Profits. The New York Times Magazine, September 13.

Fuchs, C. (2010). Labor in Informational Capitalism and on the Internet. The Information Society: 26, Taylor \& Francis Group, LLC ISSN: 0197-2243. http://dx.doi.org/10.1080/01972241003712215

Fuchs, C. The Political Economy of Privacy on Facebook.

Grahn, J. L., Hannaford, W. J., \& Laverty, K. J. (1987). Corporate philanthropy and marketing strategy: A review and directions for research. 1987 AMA Summer Marketing Educators' Conference Proceedings: 67-69.

Higgins, K. T. (1986). Cause Related Marketing: Does it pass the bottom line test? Marketing News, 20(10), 1-4

Humberg, K. M. (2001). Mapping the Field: Social business and relevant contexts. München: Oekom

Jongwook, K., \& Joseph, T. M. (2005). Property Rights Theory, Transaction Costs Theory and Agency Theory: An Organizational Economics Approach to Strategic Management. Managerial and Decision Economics, (26), 223-242. http://dx.doi.org/10.1002/mde.1218

Josephson, N. (1984). AmEx Raises Corporate Giving to Market Art. Advertising Age (January 23), M-10

Kapferer, J. N. (1997). Strategic Brand Management: Creating and Sustaining Brand Equity Long Term. 2nd edition. London: Kogan Page

Kotler, P. (1972). A Generic Concept of Marketing. Journal of Marketing, 36(2), 46-54. http://dx.doi.org/10.2307/1250977

Kumar, K. (2004). From Post Industrial to Post-Modern Society. Ankara: Dost Publishing

Lafferty, B. A., \& Goldsmith, R. E. (2005). Cause-brand Alliances: Does the cause help the Brand or Does the Brand Help the Cause? Journal of Business Research, 58, 423-429. http://dx.doi.org/10.1016/j.jbusres.2003.07.001

Lister, M., Dovey, J., Giddings, S., Grant, I., \& Kelly, K. (2009). New Media: A Critical Introduction. (2nd ed.). New York: Routledge

Macleod, S. (2001). Why worry about CSR?. Strategic Communication Management, 5(5), 8-9.

Maier, J. S. (1985). The Big Event and the Sales Promotion Campaign. Handbook of Sales Promotion, Stanley M. Ulanoff, ed. New York: McGraw-Hill Book Company

Maignan, I., \& Ralston, D. A. (2002). Corporate social responsibility in Europe and the US: insights from businesses' self-presentations. Journal of International Business Studies, 33(3).

http://dx.doi.org/10.1057/palgrave.jibs.8491028 
Mason, E. S. (1974). The Corporation in Modern Society. New York: Atheneum

McLuhan, M. (1994). Understanding Media, USA: Massachusetts Institute of Technology

Mescon, T. S., \& Tilson, D. J. (1987). Corporate Philanthropy: A Strategy Approach to the bottom-line. California Management Review, (2), 49-59. http://dx.doi.org/10.2307/41165238

Mohr, L., Webb, D., \& Katherine, H. (2001). Do consumers expect companies to be socially responsible? The impact of corporate social responsibility on buying behavior. The Journal of Consumer Affairs, 35(1)

Parnell, J. A. (2008). Sustainable strategic management: construct, parameters, research directions. International Journal of Sustainable Strategic Management, 1(1). http://dx.doi.org/10.1504/IJSSM.2008.018125

Porter, M. E. (2001). Strategy and the Internet. Harvard Business Review, 79. https://hbr.org/2001/03/strategy-and-the-internet/ar/1

Rosenfeld, J. (1985). Cashing in on a Noble Cause. Marketing Communications, (April)

Rosenthal, N. (1985). The Shrinking Middle Class: Myth or Reality?. Monthly Labor Review, 108(March), 3-10.

Saka, E. (2013). Türkiye'de Yeni Medya Çalışmaları-1. ed. Taş Mektep Yayıncılık: İstanbul

Schwartz, S. H. (2006). Les valeurs de base de la personne: Théorie, mesures et applications [Basic human values: Theory, measurement, and applications]. Revue Française de Sociologie, 47. http://dx.doi.org/10.3917/rfs.474.0929

Scott, T. (1986). Continental to Reinstate Hobby Flights. Houston Chronicle (April 30), Section 3, 1, 4.

Sen, S., \& Bhattacharya, C. B. (2001). Does Doing Good Always Lead to Doing Better? Consumer Reactions to Corporate Social Responsibility. Journal of Marketing Research, 38(May). http://dx.doi.org/10.1509/jmkr.38.2.225.18838

Solis, B. (2007). PR 2.0 is not Web 2.0. February 27. http://www.briansolis.com/2007/02/pr-20-is-not-web-20/

Stelzner, M. A. (2011). Social Media Marketing Industry Report: How Marketers Are Using Social Media to Grow Their Businesses.

Stroup, M. A., \& Ralph, L. N. (1987). The Evolution of Social Responsibility. Business Horizons, 30(March-April), 22-24. http://dx.doi.org/10.1016/0007-6813(87)90004-8

Tinsdall, P. (1982). Mars Makes a Play for Charity. Marketing (September 23), 83-84.

Van Dijk, J. (2004). Digital Media. The Sage Handbook of Media Studies, John D.H. Downing, Denis McQuail, Philip Schlesinger, Ellen Wartella (Ed.). London: Sage. http://dx.doi.org/10.4135/9781412976077.n8

Webb, J. D., \& Mohr, L. A. (1998). A typology of customers: responses to cause related marketing: from skeptics to socially concerned. Journal of Public Policy and Marketing, 17(2), 226-239.

Weber, M. (2008). The business case for corporate social responsibility: A company-level measurement approach for CSR. European Management Journal, 26, 247-261. http://dx.doi.org/10.1016/j.emj.2008.01.006

Welford, R. (2004). Corporate Social Responsibility in Europe, North America and Asia. 2004 Survey Results, JCC 17 Spring. Greenleaf Publishing.

\section{(cc) BY}

This work is licensed under a Creative Commons Attribution 3.0 License. 


\title{
Understanding the Mediating Role of Symptoms of Stress on the Perceived Access to Training and Job Satisfaction Relationship
}

\author{
James Chowhan ${ }^{1}$, Isik U. Zeytinoglu ${ }^{1}$, Margaret Denton ${ }^{1}$, Jennifer Plenderleith ${ }^{1}$ \\ ${ }^{1}$ McMaster University, Hamilton, Ontario, Canada \\ Correspondence: James Chowhan, DeGroote School of Business, McMaster University, Hamilton, Ontario, Canada
}

Received: July 10, 2015 Accepted: July 24, 2015 Online Published: October 8, 2015

doi:10.11114/bms.v2i1.941 URL: http://dx.doi.org/10.11114/bms.v2i1.941

\begin{abstract}
The purpose of this study is to examine the mediating role of symptoms of stress on the relationship between perceived access to training and job satisfaction. The changing nature of work (i.e. workplace and job complexity) has implications for stress and job satisfaction outcomes. Concerns about stress and job satisfaction levels and their link to performance have created interest in training interventions to improve the adequacy of knowledge and skills. A cross-sectional questionnaire survey of 1396 nurses was collected from three large teaching hospitals. The positive relationship between employees' perceived access to training and job satisfaction is increased by the partial mediation of symptoms of stress. Based on the evidence of this study, we recommend human resource staff and managers focus on training as a factor enhancing job satisfaction and mitigating stress.
\end{abstract}

Keywords: perceived access to training, job satisfaction, symptoms of stress, nurses

\section{Introduction}

\subsection{Introducing Study Objectives}

The increasing pace of globalization and technological innovation are generally leading to greater workplace and job complexity, and these are a source of stress for employees (Cappelli et al., 1997). The negative effects of stress on employee outcomes, such as reduced employee performance (i.e. reduced productivity and quality of output) and lower job satisfaction have an established relationship (Tetrick \& Larocco, 1987). However, the interventions that can be taken to mitigate the potential harmful effects are less well established. Interventions, such as training, have been suggested (Cooper \& Cartwright, 1994; Sullivan \& Bhagat, 1992), however, no study has comprehensively explored the path between training, stress, and job satisfaction. Employers in their pursuit of improving their workers' job satisfaction levels often focus on levers within the workplace directly under their control, we suggest that the provision of training is an important practice to consider. Some studies have explored the relationship between training and job satisfaction and found a positive relationship (Georgellis \& Lange, 2007; Jones, Jones, Latreille, \& Sloane, 2009). Nonetheless, the mediating factors affecting the training and job satisfaction relationship are not entirely understood, and in particular, the role of stress as a mediator.

When studying stress and job satisfaction, consideration of workplace and specific job contexts have been advocated for as a way to aid in a better understanding of the theoretical relationships (Fairbrother \& Warn, 2003; Sparks \& Cooper, 1999). The current study adopts this suggestion by focusing on one particular occupation group--nurses. Further, the current study draws on the nursing literature to support the development of a conceptual framework that is more situation specific, both in terms of the workplace and job contexts.

The importance of training in keeping nurses' knowledge and skills up to date, and the positive relationship between training and improvements in patient care is continuing to gaining awareness (West, Mays, Rafferty, Rowan, \& Sanderson, 2009). The link between training and performance is particularly important in the field of health care where up-to-date clinical procedures are essential for providing quality patient care. Recently, evidence has been found for a link between both professional development and the availability of information provided to nurses and their satisfaction with the care provided to patients (Roulin, Boul'ch, \& Merlani, 2012), and for a link between competency satisfaction and job performance satisfaction (Tzeng, 2004).

Job satisfaction is important because of its positive and moderate association with employee job performance (Judge, 
Thoresen, Bono, \& Patton, 2001). In the context of nurses, job satisfaction is important because job performance includes patient care (Tzeng, Ketefian, \& Redman, 2002). The need to maintain a high standard of care for patients creates the potential for on-going stress because deficiencies in knowledge and skill due to a lack of training can have serious consequences for patients (Paige, 2010). Adverse events for patients have been linked to increasing stress levels among health care workers (Wrenn, Lorenzen, Jones, Zhou, \& Aronsky, 2010). Thus, it is important to understand factors that can help mitigate stress and improve job satisfaction. This relationship is important for nurses but it also applies generally for all employees; however, research has tended to focus on higher stress occupations (Fairbrother \& Warn, 2003; Sparks \& Cooper, 1999).

The effects of perceived access to training on job satisfaction and the possible mediating effect of stress on this relationship has not been explored in the training and development, human resource management, or nursing literatures. The objective of this study is to examine the association between employees' perceived access to training and job satisfaction, and whether or not stress mediates the perceived access to training and job satisfaction relationship.

This topic is important for both managers and human resource managers because training enables employees to maintain and enhance their knowledge and skills within a workplace that is becoming increasingly complex. This is particularly the case in the nursing profession; thus, training is imperative for nurses to adequately perform the tasks of their jobs. Nurses deal with sick and potentially vulnerable individuals who need care, and the patients look upon nurses to receive the good quality care they need. Nurses know that the knowledge they gain through training is essential for patient care and any deficiencies in their training may have serious consequences for patients' health. Thus, a perceived lack of access to training can affect their stress levels contributing to lowered job satisfaction. Exploring these relationships within the situational-context of the nursing occupation contributes to knowledge by identifying the nuances of these relationships within a particular workplace and job specific context. Findings from our study can assist managers and human resource managers by informing and contributing to human resource policy development in organizations. Findings can also inform decision-makers at national and intergovernmental organizations on the importance of access to training for employees' stress and job satisfaction. More generally, the findings can inform the decisions of managers whose employees operate in similar situational contexts and environments as nurses and that may have similar stress levels.

\subsection{Conceptual Model}

Job satisfaction is often thought of as an attitudinal concept that captures how people feel about their job and aspects of their job (Spector, 1997). Spector identifies workload, job control, perspective of roles, job stress, pay, work schedules, and support as common job characteristic and environmental factors that affect job satisfaction. Many of these factors are among the most frequently identified factors associated with nurses' job satisfaction, including stress, supervisor and co-worker support, and control over their job (Blegen, 1993). Recent studies focusing on nurses' job satisfaction have included many additional factors (i.e. workload, shifts and scheduling, job demands, professional training, and remuneration) that have contributed to greater understanding of the key relationships ( $\mathrm{Lu}$, Barriball, Zhang, \& While, 2012; Zeytinoglu et al., 2007).

The present study builds on this growing literature by developing a conceptual model for understanding the relationship between perceived access to training, symptoms of stress, and job satisfaction--with symptoms of stress examined as a mediator. Further, we include the key antecedents of job satisfaction identified in the human resource management and nursing literatures to allow for alternate explanations in the analyses.

We suggest that training is essential for employees, and in particular nurses, to adequately perform their duties. As a regular part of their tasks and work, nurses care for individuals, by providing services that range from health promotion to caring for those with illness, disease, or disability. Families and patients expect good quality care from nurses when they need it. Nurses know that the skills and expertise they acquire through training is vital for patient care. The importance of training for performance is well established in the human resource management literature (Dysvik \& Kuvaas, 2008; Jones et al., 2009). Further, nurses understand that any gaps in their training may have grave consequences for patients. Thus, we argue that a perceived lack of access to training can affect nurses' stress levels, and that higher stress levels are contributors to lowered job satisfaction. The conceptual model of the interrelationships between these factors is schematically presented in Figure 1. In the remainder of this section some key concepts are defined, then support from the literature for each of the key relationships are presented. 


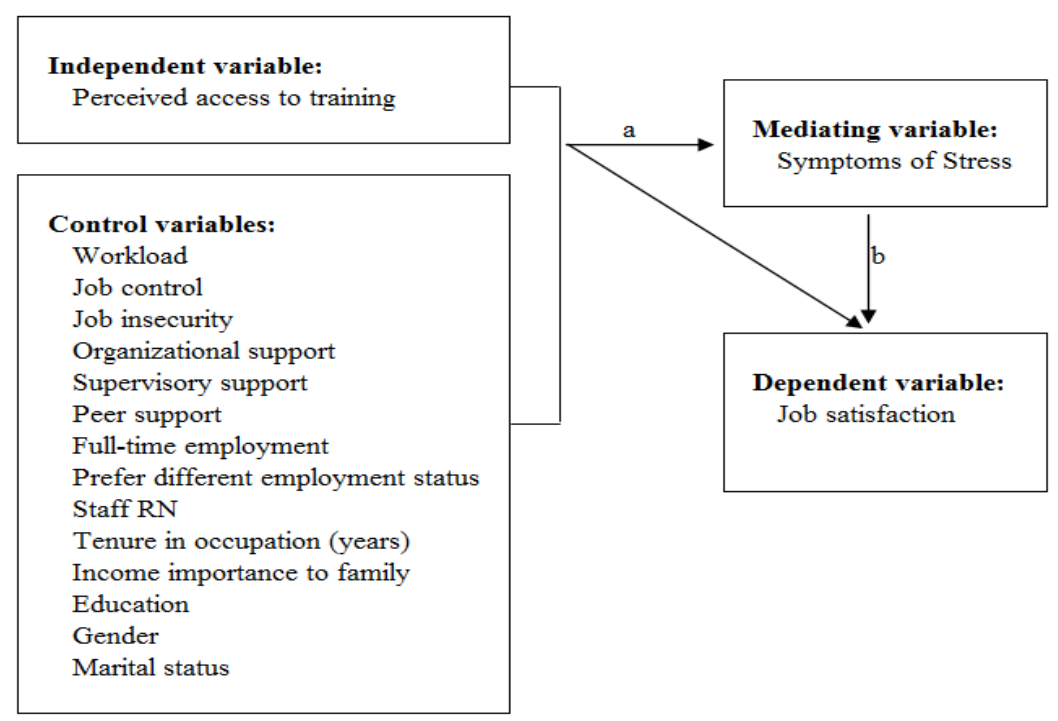

Figure 1. The conceptual model of the associations between perceived access to training, symptoms of stress, and job satisfaction.

\subsection{Definitions}

We focus on the concept of perceived access to training because unlike traditional conceptualizations of training in the human resource literature--that focus on objective measures of incident (whether training was received) or intensity (number of courses, number of hours, number of days of training, or number of years (Cooke, Chowhan, \& Brown, 2011; Georgellis \& Lange, 2007; Jones et al., 2009), for example)--the perceived access to training scale measures perceived employer-support and employee need for training and avoids implicitly assuming these exist because training was observed. In one study that looks at perceived access to training, Bartlett (2001, p. 339) identifies two main elements: 1) employees' belief that they have access to needed job-related knowledge and skills training, and 2) employees' perception that there are limited organizational constraints on employee participation in training. We contribute to the training and development sub-field of the human resource management literature by adopting Bartlett's definition and these two elements for our study. Further, we argue that these are critical elements of training that have not been addressed sufficiently in earlier studies.

Many studies, when investigating stress, do not clearly distinguish the dimensions of stress. For the current study, we make a distinction between sources of stress and types of stress (such as symptoms of stress) (Denton, Zeytinoglu, Davies, \& Lian, 2002; Zeytinoglu, Denton, Plenderleith, \& Chowhan, 2015), and focus on symptoms of stress conceptually and empirically (definitions for the main variables of interest are discussed in more detail in the methods section below). Thus, in the current study, the focus is not on job stressors (i.e. an event or workplace condition that requires an adaptive response, such as workload, job control, job insecurity, pay, and work schedules--although we control for these relevant variables in the analysis), but on the response to stressors (i.e. job strain) and specifically physical and psychological reactions, which we refer to as symptoms of stress (Denton et al., 2002; Fairbrother \& Warn, 2003; Spector, 1997).

\subsection{Key Relationships}

The empirical relationship between objective measures of training and job satisfaction shows that employer-sponsored training has a significant positive relationship with job satisfaction (Georgellis \& Lange, 2007; Jones et al., 2009). This relationship is not only robust in the human resource management literature, which tends to use national samples in these types of analyses, but it persists in the nursing literature (Chen, Chen, Tsai, \& Lo, 2007; Ramirez, Graham, Richards, Cull, \& Gregory, 1996). There is one study in the human resource development literature, that the authors are aware of, that finds a positive significant correlation between perceived access to training and job satisfaction (Bartlett, 2001); however, this relationship was not explored in a multivariate analyses. A related vein of human resource training and development literature looks at perceived access to training's positive effect on employee outcomes including commitment, intrinsic motivation, task performance, organizational citizenship, and turnover intention (Bartlett, 2001; Dysvik \& Kuvaas, 2008). This literature suggests that employee beliefs about the employment relationship and real or perceived entitlements contribute to shaping reciprocal attitudes and behaviors; and that perceived access to training has significant moderate positive correlations with employee outcomes (Bartlett, 2001; 
Dysvik \& Kuvaas, 2008). These consistent findings across the various measures of training, and in particular for perceived access to training, leads to the expectation that perceived access to training will be positively associated with job satisfaction. In our analyses below, we first establish this well-known association between perceived access to training and job satisfaction before continuing with the test for mediation.

The beneficial effect of training on stress has received some attention over the last two decades (Cooper \& Cartwright, 1994). In particular, a decline in the emphasis by employers on workplace learning and the availability of training opportunities puts increasing stress on employees to "manage their own development and careers" (Cappelli et al., 1997, p. 10). The shift away from an internal labour market focus has made it increasingly difficult for employees to maintain skill levels (Cappelli et al., 1997). Frameworks looking at occupational stress interventions have included career development and training as an important intervention to build knowledge, skill, and occupational competence (Cooper \& Cartwright, 1994; Sullivan \& Bhagat, 1992). One study that the authors are aware of has looked at the perceived access to training and stress relationship; specifically, Teo and Waters (2002) look at the relationship between human resource practices (including the opportunity for training and development) on both vocational strain and interpersonal strain. These authors found that, other than stress management intervention practices, the opportunity for training was a main significant and substantial contributor to reduce both vocational and interpersonal strain (Teo \& Waters, 2002, p. 219).

With regard to health care personnel, some studies identify a link between insufficient or perceived inadequacy of training and stress (Graham, Ramirez, Finlay, Hoy, \& Richards, 1996; Ramirez et al., 1996), and also highlight the need for training to mitigate these risks (Graham et al., 1996). A meta-analysis by Ruotsalainen et al. (2008) looked at the effectiveness of interventions on symptoms of stress and found that stress management interventions such as developing knowledge and skills can have positive effects for nurses. These findings, taken together, suggest that when training focuses on job knowledge and skills it has an integral role to play in helping to reduce stress levels. Applying this knowledge, we argue that any gaps in knowledge and skills can affect perceived performance contributing to employee stress, and when employees perceive they have access to training that can assist them, in adequately performing their tasks they will be less stressed. Similarly, but with respect to nurses, competency gaps can affect perceived patient care contributing to nurses' stress; however, we argue that when nurses perceive they have access to training that enables them to adequately provide patient care, they will be less stressed. In our study, we also establish the well-known association between training and stress, focusing on perceived access to training and symptoms of stress.

The negative relationship between psychological and physical symptoms of stress and job satisfaction has been robust in the human resource management literature (Judge, Ilies, \& Zhang, 2012; Sullivan \& Bhagat, 1992); however, the relationship is not always significant in all job and environmental contexts (Judge et al., 2012). Thus, the literature supports the negative relationship between stress and job satisfaction, but it suggests an importance in investigating the significance of the relationship across different job and workplace contexts. Different occupations and environments may have salient features that potentially lead to differing stressors and symptoms of stress outcomes (Fairbrother \& Warn, 2003; Sparks \& Cooper, 1999).

Empirical research that focuses on nurses has also shown a significant negative relationship between stress and job satisfaction (Lu et al., 2012; Ramirez et al., 1996; Tetrick \& Larocco, 1987). For example, Zeytinoglu et al. (2005) find that as symptoms of stress increase job satisfaction decreases for nurses. Further, a study by Chen et al. (2007) looking at nurse specialists found that role stress accounted for the majority of the variation in job satisfaction. It is important to note that Chen et al. (2007) also included nurse specialist training in their analyses and found that training is a substantial positive contributor to job satisfaction.

Considering the research on the relationship between training and stress (discussed above) and stress and job satisfaction, the combination of these results suggest that perceived access to training (i.e. belief that they have access to needed job-related training and limited organizational restrictions on training participation) can diminish symptoms of stress and that lower stress levels contribute to higher job satisfaction leads to the following hypothesis (see figure 1):

Hypothesis 1: Symptoms of stress mediates the relationship between perceived access to training and job satisfaction for nurses.

\section{Method}

\subsection{Data and Survey Participant Characteristics}

The survey sample was drawn from three large teaching hospitals in Southern Ontario. All nurses employed at the hospitals were included in the study target population. After an initial pilot questionnaire was tested, the survey was sent by mail to 2,684 nurses in the participating hospitals. The total response rate was $52 \%$ (individual hospital response rates ranged from 40 to 59\%) with a final sample size of 1,396. The survey was conducted between April 
2002 and July 2002. For key demographic characteristics, such as age, gender, and occupation (i.e. percentage of registered nurses and registered practical nurses), our data are substantially similar to comparisons between 2003 and 2012 for Ontario (College of Nurses of Ontario, 2012).

\subsection{Variables and Measurement}

For the measurement model underlying Figure 1, confirmatory factor analysis was conducted using all of the items for the scales used in the path analysis. All items for all scales were measured on a five point Likert scale; for example, $1=$ strongly disagree, $2=$ disagree, $3=$ neither agree nor disagree, $4=$ agree, and $5=$ strongly agree. $\quad$ All factor loadings were significant $(\mathrm{p}<0.01)$ and the model exhibited an acceptable fit, detailed results are available upon request from the first author. With regard to scale reliability Cronbach's alphas are presented below (see Table 1 diagonal). Further, to test for common method variance (CMV) we added a first-order factor to the measurement model underlying Figure 1-this is equivalent to the single-method-factor approach (Podsakoff, MacKenzie, Lee, \& Podsakoff, 2003). For the CMV latent factor, none of the factor loadings for all items (for all scales included in the model) were significant. This is an indication that CMV is not likely a concern (additional details are available upon request).

Spector's 1985 Job Satisfaction Survey (JSS) (Spector, 1997, pp. 75-76) was adapted for the dependent variable job satisfaction measure. The questions assess nine facets of job satisfaction including pay, benefits, contingent rewards, promotion opportunities, immediate supervisor, rules and procedures, co-workers, type of work, and communication within the organization. The overall job satisfaction scale includes all 36 items summed. The overall job satisfaction scale had a Cronbach's alpha of .89 indicating a high reliability (and mean $=110.3$, standard deviation $=15.3$, and a range from 36 to 180 indicating a moderate level of satisfaction).

Perceived access to training was measured with items developed by Zeytinoglu, Denton, Davies, Higgins, Blythe, and Baumann (2002). Exploratory factor analysis, using an iterated principal factors extraction method, resulted in one single factor being revealed consisting of eight items and that accounted for $86 \%$ of the variance. The items used are as follows: "a) my schedule prevents me from taking courses/furthering my education, b) access to education varies across units in this hospital, c) support for education is subject to favouritism, d) support for education is inequitable, f) there is a lack of funding for education in my unit, g) there is a lack of funding for education in this hospital, h) there is not sufficient training for new technologies and procedures, and i) I don't feel I am adequately trained in some technologies and procedures" (Zeytinoglu et al., 2002, p. 20). These items all had acceptably high factor loadings. The item "e) I would like to further my education" is not included because of its low communality below the commonly used 0.2 threshold. The perceived access to training scale can be described as a measure of an employees ' perception of employer-support and employee need for training. The retrospective nature of this variable also provides some support for its use in a mediation model. The perceived access to training scale has a Cronbach's alpha of .77 indicating an adequate internal consistency reliability, and the mean was 22.0 (std. dev. $=4.7$ and range 8 to 40 ) indicating moderate feelings with regard to levels of training access.

Stress measures vary from focusing on sources of stress (stressors such as work intensification, workload, feeling overloaded, dealing with suffering, having managerial responsibilities, and feeling poorly managed and resourced) (Graham et al., 1996; Zeytinoglu et al., 2007), role stress (including dimensions such as role conflict, ambiguity, overload, incompetence, over-qualification, and incongruity) (Chen et al., 2007; Tetrick \& Larocco, 1987) to overall measures of stress ("overall how stressful do you find your work?") (Ramirez et al., 1996, p. 726). The present study focuses on symptoms of stress, and we clearly delineate the dimensions of stress by separately measuring the dimensions of sources and types of stress (i.e. we include workload, job control, and job insecurity in the models, see details below).

The symptoms of stress scale is a 14-item symptom measure based on previous work by Denton, Zeytinoglu, Webb, and Lian (2002). Items were used to collect reflections on each statement about how often they felt in the past month: (1) exhausted at the end of the day, (2) headaches or migraines, (3) unable to sleep through the night, (4) felt like crying, (5) lack of energy on the job, (6) burnt out, (7) felt like yelling at people, (8) felt like there is nothing more to give, (9) difficulty concentrating, (10) angry, (11) helpless, (12) not in control of my life, (13) irritable and tense, and (14) dizzy (Denton et al., 2002). Because these items are retrospective over the past month their use in a cause and effect mediation model has some support. The aggregate symptoms of stress scale had a Cronbach's alpha of .87 indicating high internal reliability and a mean of 32.4 (std. dev. = 7.9 and range from 14 to 70 ) indicating moderate levels of stress symptoms being felt by nurses.

In addition to demographic variables, control variables related to the employee's job and employment relationships have been included in the analysis to account for alternative explanations of job satisfaction outcomes identified in the literature ( $\mathrm{Lu}$ et al., 2012). Six items measuring work demands were used to create a workload scale (alpha $=.85)$, see Denton, Zeytinoglu, Davies, and Lian for details (2002, p. 337). A seven item job insecurity scale (alpha $=.88$ ) was 
adopted from Zeytinoglu et al. (2007, p. 210). For brevity items from previously validated scales are not listed here and their source has been referenced.

Exploratory factor analysis was used to develop a job control scale for inclusion in the path analysis regression. A series of eight items covering job decision latitude and discretion were included in the exploration, detailed output are available from the first author upon request. The Cronbach's alpha for the job control scale indicates an acceptable reliability (alpha $=.70)$. Workload and job control are included in the path analysis regression to account for the long established relationship with symptoms of mental strain (i.e. psychological strain including exhaustion and depression) and subsequent job satisfaction (Schmidt \& Diestel, 2011; Tetrick \& Larocco, 1987). Finally, organizational support, supervisory support, and peer support were also included (alphas equal to $.74, .94, .80$, respectively). Organizational support has six items, supervisory support has six items and peer support has four items. These variables are discussed in more detail in Zeytinoglu et al. (2007). Organizational, supervisory, and peer support have been identified as having moderate positive correlations with job satisfaction in the literature (Blegen, 1993; Utriainen \& Kyngas, 2009).

Several variables measuring employment characteristics are included: type of employment, nursing position, and importance of income. There were three types of employment status measured: Full-time employment status is coded full-time (59\%) equal to one and zero otherwise; and part-time $(33 \%)$ and casual employees $(8 \%)$ are combined to comprise the reference group. The prefer different employment status variable is coded as equal to one if nurses preferred a different employment status than the one they are currently in and zero otherwise. Nurses were asked to indicate their primary position in nursing at the hospital, the variable Staff $R N$ was coded as equal to one if the nurse's primary position was as a Staff Registered Nurse and zero otherwise--84\% were Staff RNs. The tenure in occupation variable is the number of years in the nursing profession. The average tenure was 18 years $(\mathrm{SD}=10.3)$. Age is not included in the analysis to avoid collinearity with tenure; however, the average age is 42 years $(\mathrm{SD}=9.5)$. Nurses were asked to rate the importance of income to the family's economic well-being (income importance to family), 59\% rated their income as very important on the scale " $1=$ not at all important to $5=$ very important", very important responses were coded as equal to one and all other responses were coded as zero. Additional demographic control variables include gender (female), education, and marital status. For the education variable, University degree (22\%) is coded as equal to one if the nurse had completed a Bachelor's degree, post-graduate degree MA, or PhD and all other levels of education were coded as zero. Gender is coded as female equal to one and male equal to zero. Most of the survey participants (96\%) were female. With regard to marital status, $72 \%$ were married or living with a partner, coded as equal to one if the nurse was married or living with a partner and zero otherwise. Missing values were imputed for all variables included in the analysis and as a result the final sample used in the analysis was $\mathrm{n}=1396$.

\subsection{Statistical Analysis}

All scale variables were standardized (z-scores) for the path analysis regression, with the exception of tenure in occupation measured in years, so that all multivariate analysis generally uses only standardized continuous variables or binary variables. Standardizing scale variables aids in the interpretability of the output. For example, the regression coefficients represent the amount the standardized dependent variable will change in units of its own standard deviation with respect to a one standard deviation change in the standardized independent variable. This is very useful because the results can be understood in the context of the distribution of the variables of interest (i.e. units of standard deviation). In contrast, unstandardized results are difficult to interpret given scales' ranges vary and no context for comparison across scales exists in unstandardized measures for a one unit change.

Stata 13 was used for all analyses. With regard to the path analysis regression (using maximum likelihood), the equivalent of Baron and Kenny's (1986) three-stage regression analysis was used to test for mediation: (1) the independent variable needs to affect the mediator when the mediator is regressed on the independent variable (Model 1), (2) the independent variable needs to also affect the dependent variable (Model 2), and (3) in a fully specified regression the mediator needs to affect the dependent variable and the independent variable's effect should be less (Model 3), where "less", in the case of strong mediation, implies a non-significant zero parameter estimate (Baron \& Kenny, 1986). If all of the above models have significant relationships then it can be said that the linkages of the mediational model have been confirmed. Adjusted R-squared was used to show the additional variance explained while moving toward the full mediation model. It is important to note that the mediation relationship being empirically tested is not causal, but rather the modelled paths suggest associations. Our cross-section data do not enable a proper test of cause and effect.

\section{Results}

Mean and standard deviation estimates for all variables used in the analyses are presented in Table 1. For each of the scale variables, the Cronbach's alpha reliability estimate is above the commonly accepted 0.70 threshold, see Table 1 . For the correlations, all relationships are in the expected direction. It is important to note that the correlation 
relationships necessary for mediation are present. The correlation between perceived access to training and symptoms of stress is $r=-0.31 \quad(p<0.01)$. Further the correlations between job satisfaction and symptoms of stress and job satisfaction and perceived access to training are $r=-0.49(p<0.01)$ and $r=0.54(p<0.01)$, respectively.

Table 1. Descriptive, Reliability and Correlation Estimates of Scale Variables ${ }^{\text {a }}$

\begin{tabular}{|c|c|c|c|c|c|c|c|c|c|c|c|c|}
\hline & & Mean & Std. Dev. & 1 & 2 & 3 & 4 & 5 & 6 & 7 & 8 & 9 \\
\hline 1 & Job satisfaction & 110.3 & 15.33 & 0.89 & & & & & & & & \\
\hline 2 & Perceived access to training & 22.0 & 4.74 & 0.54 & 0.77 & & & & & & & \\
\hline 3 & Symptoms of stress & 32.4 & 7.93 & -0.49 & -0.31 & 0.87 & & & & & & \\
\hline 4 & Workload & 20.6 & 4.44 & -0.47 & -0.27 & 0.41 & 0.85 & & & & & \\
\hline 5 & Job control & 14.4 & 3.24 & 0.52 & 0.34 & -0.31 & -0.30 & 0.70 & & & & \\
\hline 6 & Job insecurity & 15.5 & 4.96 & -0.20 & -0.17 & 0.13 & 0.00 & -0.07 & 0.88 & & & \\
\hline 7 & Organizational support & 16.5 & 3.83 & 0.65 & 0.58 & -0.38 & -0.32 & 0.52 & -0.20 & 0.74 & & \\
\hline 8 & Supervisory support & 19.1 & 5.55 & 0.60 & 0.39 & -0.25 & -0.18 & 0.42 & -0.11 & 0.53 & 0.94 & \\
\hline 9 & Peer support & 15.5 & 2.49 & 0.31 & 0.18 & -0.19 & -0.14 & 0.25 & -0.18 & 0.22 & 0.26 & 0.80 \\
\hline
\end{tabular}

${ }^{a} \mathrm{n}=1396$, the diagonal reports each scale's Cronbach's alpha to aid in the assessment of reliability (in italics). All variables are continuous. Correlations whose absolute values are greater than .03 are significant at the 0.05 level (2-tailed).

Table 2 presents the path analysis regression models for all the steps of the mediation analysis. The continuous variable coefficients are in standard deviation units, so a one standard deviation change, in for example Model 1's perceived access to training variable decreases stress by .08 standard deviations. Model 1 presents the first step of the mediation test of perceived access to training on stress. Models 2 and 3 test the second and third steps of the mediation. F-tests indicate that all models are significant at the $1 \%$ level of significance. Further, the mediation models ( 2 to 3 ) show that a significant incremental amount of variance is explained from the addition of the mediator variable symptoms of stress--the adjusted $R$-squared increased about $2 \%$ from $R^{2}=0.638(F=164.8, p<0.001)$ to $R^{2}=$ $0.654(\mathrm{~F}=166.1, \mathrm{p}<0.001)$.

Table 2. Perceived Access to Training and Control Factors Associated with Job Satisfaction, with Symptoms of Stress as a Mediator ${ }^{\text {a }}$

\begin{tabular}{|c|c|c|c|c|c|c|c|c|c|}
\hline \multirow[b]{2}{*}{ Dependent Variable } & \multicolumn{3}{|c|}{$\begin{array}{c}\text { Model } 1 \\
\text { Symptoms of Stress }\end{array}$} & \multicolumn{3}{|c|}{$\begin{array}{c}\text { Model } 2 \\
\text { Job Satisfaction }\end{array}$} & \multicolumn{3}{|c|}{$\begin{array}{c}\text { Model } 3 \\
\text { Job Satisfaction with stress } \\
\text { included }\end{array}$} \\
\hline & $\mathrm{B}$ & & S.E. & $\mathrm{B}$ & & S.E. & $\mathrm{B}$ & & S.E. \\
\hline Constant & -0.19 & & 0.152 & -0.43 & $* * *$ & 0.107 & -0.46 & $* * *$ & 0.105 \\
\hline \multicolumn{10}{|l|}{ Independent variable } \\
\hline Perceived access to training & -0.08 & $* *$ & 0.029 & 0.15 & $* * *$ & 0.020 & 0.14 & $* * *$ & 0.020 \\
\hline \multicolumn{10}{|l|}{ Control variables } \\
\hline Workload & 0.29 & $* * *$ & 0.025 & -0.24 & $* * *$ & 0.018 & -0.19 & $* * *$ & 0.018 \\
\hline Job control & -0.08 & $* *$ & 0.028 & 0.13 & $* * *$ & 0.020 & 0.11 & $* * *$ & 0.019 \\
\hline Job insecurity & 0.07 & $* *$ & 0.024 & -0.05 & $* *$ & 0.017 & -0.04 & $*$ & 0.017 \\
\hline Organizational support & -0.15 & $* * *$ & 0.033 & 0.23 & $* * *$ & 0.024 & 0.21 & $* * *$ & 0.023 \\
\hline Supervisory support & -0.03 & & 0.028 & 0.28 & $* * *$ & 0.020 & 0.28 & $* * *$ & 0.019 \\
\hline Peer support & -0.06 & $*$ & 0.024 & 0.09 & $* * *$ & 0.017 & 0.08 & $* * *$ & 0.017 \\
\hline Full-time employment & 0.18 & $* * *$ & 0.049 & -0.03 & & 0.034 & 0.00 & & 0.034 \\
\hline Prefer different employment status & 0.15 & $* *$ & 0.057 & -0.07 & & 0.040 & -0.05 & & 0.039 \\
\hline Staff RN & -0.02 & & 0.065 & 0.23 & $* * *$ & 0.046 & 0.23 & $* * *$ & 0.045 \\
\hline Tenure in occupation (years) & -0.01 & $* * *$ & 0.002 & 0.01 & $* * *$ & 0.002 & 0.01 & $* * *$ & 0.002 \\
\hline Income importance to family & 0.08 & & 0.049 & -0.06 & & 0.035 & -0.05 & & 0.034 \\
\hline University & -0.01 & & 0.056 & 0.01 & & 0.039 & 0.01 & & 0.039 \\
\hline Gender (female) & 0.18 & & 0.122 & 0.15 & & 0.086 & 0.17 & $*$ & 0.084 \\
\hline Married or living with a partner & -0.01 & & 0.053 & 0.04 & & 0.037 & 0.04 & & 0.036 \\
\hline \multicolumn{10}{|l|}{ Mediation variable } \\
\hline Symptoms of Stress & -- & & -- & -- & & -- & -0.15 & $* * *$ & 0.019 \\
\hline $\mathrm{F}$ & 36.0 & $* * *$ & & 164.8 & $* * *$ & & 166.1 & $* * *$ & \\
\hline Adjusted R-Square & 0.274 & & & 0.638 & & & 0.654 & & \\
\hline
\end{tabular}


Model 2 shows strong support that perceived access to training positively affects job satisfaction. Perceived access to training has one of the largest positive effects $(B=0.15, p<0.001)$ preceded by organizational support $(B=0.23, p<$ $0.001)$ and supervisory support $(B=0.28, p<0.001)$, and staff $R N(B=0.23, p<0.001)$. Tenure in nursing occupation also had a substantive positive significant effect. For example, for every one year increase in occupation tenure the job satisfaction coefficient increased by .01 standard deviations (or .1 for every ten years). Workload and job insecurity have significant negative effects on job satisfaction.

The analysis in Model 1 shows perceived access to training is significantly and negatively related to symptoms of stress $(B=-0.08, p<0.01)$. Job control, organizational support, peer support and occupational tenure also had significant negative associations with symptoms of stress, whereas workload, job insecurity, having full-time employment, and preferring different employment status were all positively and significantly related to symptoms of stress.

Model 3, shows the third stage in the mediation test, both the mediator symptoms of stress $(B=-0.15, p<0.001)$ and the independent variable perceived access to training $(B=0.14, p<0.001)$ have substantial significant effects on job satisfaction. The positive effect of perceived access to training is partially mediated by the negative effect of stress in that the perceived access to training effect is smaller. Thus, there is support for Hypothesis 1. Further, the indirect effect, the product of the effects of perceived access to training on stress (path a, in model $1, B=-.08, p<0.01$ ) and the effect of symptoms of stress on job satisfaction (path $\mathrm{b}$ in model $3, \mathrm{~B}=-.15, \mathrm{p}<0.01$ ) is $\mathrm{B}=0.012$ and significant at the $1 \%$ level. Both the Sobel $z$-value test $\left(z\right.$-value $=a * b / S Q R T\left(b^{2}{ }^{2} s_{a}{ }^{2}+a^{2} * s_{b}{ }^{2}\right)$ ) and the Baron and Kenny (1986) modified Sobel test equation, which is equivalent to the Aroian test ( $\mathrm{z}$-value $=\mathrm{a} * \mathrm{~b} / \operatorname{SQRT}\left(\mathrm{b}^{2} \mathrm{~s}_{\mathrm{a}}{ }^{2}+\mathrm{a}^{2 *} \mathrm{~s}_{\mathrm{b}}{ }^{2}+\mathrm{s}_{\mathrm{a}}{ }^{2 *} \mathrm{~s}_{\mathrm{b}}{ }^{2}\right)$ ) are used to calculate the standard errors, where the $\mathrm{z}$ test statistics are 2.75 and 2.73 , respectively, and where $\mathrm{a}$ and $\mathrm{b}$ are path coefficients and $s_{a}$ and $s_{b}$ are their standard errors, see figure 1 for the paths. This indicates that perceived access to training has a positive effect on job satisfaction via reduced symptoms of stress--accounting for $8 \%$ of the total effect (i.e. $8 \%=0.012 / 0.15$, where the total effect equals the direct plus the indirect effects, $0.14+0.012=0.15$ ). The magnitude of this mediation relationship can be described as relatively weak. This implies symptoms of stress is not a dominant mediator, and that there may be multiple factors mediating the perceived access to training and job satisfaction relationship.

\section{Discussion}

The findings for mediation indicated that symptoms of stress is a mediator, though weak, accounting for only $8 \%$ of the total relationship between perceived access to training and job satisfaction. This suggests that most of the benefits from higher perceived access to training on job satisfaction come from the direct association rather than indirect relationship through symptoms of stress. The level of variance explained by our models is at the higher end of the range of models looking at a similar set of variables (Bartlett, 2001; Lu et al., 2012).

We contribute to the literature by showing the partial mediating role of symptoms of stress in the relationship between perceived access to training and job satisfaction, while controlling for alternative explanations. Our findings extend previous studies that only looked at components of the comprehensive model we present. In particular, previous studies have found that training is negatively related to stress (Ruotsalainen et al., 2008) and perceived access to training is positively related to job satisfaction (Bartlett, 2001; Chen et al., 2007; Gazioglu \& Tansel, 2006); and symptoms of stress is negatively associated with job satisfaction (Denton et al., 2002; Zeytinoglu et al., 2005). Further, with regard to our conceptualizations of training and stress, we argue that our emphasis on perceived access to training and symptoms of stress focus on dimensions (of training and stress respectively) that have not been given adequate attention in the human resource management literature. When studying stress, we believe it is important to clearly delineate and separate the dimensions of stress being explored. For training, we argue that the use of a measure of perceived access to training, which encompasses employer-support and employee need, includes two critical elements of training that have not been addressed sufficiently in previous studies.

Similar to Teo and Waters' (2002) findings, our results suggest that among the possible human resource practices employers can choose from, access to training and development have an important role to play in contributing to employee outcomes. Thus, in addition to being concerned with human resource practices that contribute to workload, job control, job insecurity, and support for employees, managers need to be concerned with the access of training and development for all workers. From a strategic human resource management perspective, access to training can be seen as a workplace practice that reduces stress and increases job satisfaction. Training opportunities enable employees to adjust to changes, including not just the learning of tasks and skills in their current job, but also learning that focuses on broadening the employee's view of the organization (i.e. cross-training and development) (Traut, Larsen, \& Feimer, 2000 , p. 348).

In the context of health staff, our results suggest that hospital administrators and nurse managers need to be concerned with nurses' access to training and development because it can reduce stress and increase job satisfaction. By 
prioritizing and promoting access to training, nurse managers can attain training outcomes that include nurses receiving appropriate training and development, and being able to maintain and update their skills and knowledge. Training is one of the key levers available to hospital administrators and nurse managers to improve upon the state of current outcomes. Training opportunities enable nurses to adjust to changes in evidence-based practice and clinical procedures. Thus, when nurses have the knowledge and skills to be able to adequately perform the tasks of their jobs (i.e. dealing with sick patients in need of care), they are more likely to be able to provide a high level of patient care free from deficiencies and lacking serious consequences for patients.

With regard to organization level effects, if the improvements in reduced symptoms of stress and higher job satisfaction at the individual level can be generalized to the unit or organization level then training may contribute to managing stress levels and improving job satisfaction across the organization. In other words, in the context of health staff, hospital level outcomes can be improved through the demonstration of (additional) hospital management support and enabling nurses to satisfy their training needs. The benefits of training should not be overlooked or under-appreciated.

\subsection{Limitations and Future Research Directions}

The current study is not without limitations. With regard to generalizability, the sample only focused on three large hospitals, so the degree to which the nurses in these hospitals are representative of the nursing occupation, or the health care industry more generally, impacts the generalizability of the results. Beyond nursing as an occupation, Sparks and Cooper's (1999) finding of similar magnitude correlations between mental and physical health and occupational stressors (such as workload, pay, hours of work, control, support, and opportunities for personal development) across a variety of occupations (from civil servants, manual workers, telecommunications engineers to nursing staff) indicates that these findings may extent to other occupations.

The relationships found in the current study cannot be considered causal. The use of data from a single time period (i.e. a cross-sectional research design and not a longitudinal design) implies the data will not be able to assess directional causality between the identified relationships.

With regard to future research, a focus on other mediators is possible. Our results indicate that addressing issues of workload and organizational support may be potential alternative interventions. However, workload and organizational support may also be potential mediators of the perceived access to training and job satisfaction relationship. For example, workload is moderately correlated with perceived access to training. Management's support for training and addressing employees' skill needs may be key elements that enable employees to better manage the demands of their jobs. By creating a better understanding of technologies and procedures, productivity efficiencies are more likely to emerge leading to reduced workload demands. Thus, given the partial mediating role of stress, a focus on other mediators of the training and job satisfaction relationship, such as workload, may prove valuable. Further, given the partial mediation results presented above, the evidence suggests that the role of training should be considered additive to the possible actions that could be taken by managers.

\subsection{Conclusion}

Access to training is one way for managers to reduce employees' stress and increase job satisfaction--through skill maintenance and enrichment. These interventions also address issues of skill gaps among employees and skill obsolescence, and the need for employees to update or acquire new knowledge and skills to be effective at their tasks and duties. These types of interventions are critical to indicating support for and access to training that encourages job satisfaction. Understanding the utility or effectiveness of varying human resource practices and interventions on mitigating stress is critical for managers with limited resources to devote to reducing or controlling the effects of stress.

\section{Acknowledgements}

We thank the research project team members, S. Davies and A. Higgins for their assistance at various stages of this research. This study is supported by a grant from the Social and Economic Dimensions of an Aging Population II Research Program funded by the Social Sciences and Humanities Research Council of Canada. Survey data were collected under Dr. Zeytinoglu and Dr. Denton's management with funding from the Canadian Institutes of Health Research and Ontario Ministry of Health and Long-term Care operating grant to Dr. A. Bauman as the Principal Investigator and Drs. J. Blythe, I.U. Zeytinoglu, M. Denton and L. O'Brien-Pallas as Co-Investigators. Views expressed in this article are the authors' and do not necessarily reflect the views of the granting organizations.

\section{References}

Baron, R. M., \& Kenny, D. A. (1986). The Moderator-Mediator Variable Distinction in Social Psychological Research: Conceptual, Strategic, and Statistical Considerations. Journal of Personality and Social Psychology, 51(6), 1173-1182. http://dx.doi.org/10.1037/0022-3514.51.6.1173 
Bartlett, K. R. (2001). The Relationship Between Training and Organizational Commitment: A study in the Health Care Field. Human Resource Development Quarterly, 12(4), 335-352. http://dx.doi.org/10.1002/hrdq.1001

Blegen, M. A. (1993). Nurses' Job Satisfaction: A Meta-Analysis of Related Variables. Nursing Research, 42(1), 36-41. http://dx.doi.org/10.1097/00006199-199301000-00007

Cappelli, P., Bassi, L., Katz, H., Knoke, D., Osterman, P., \& Useem, M. (1997). Change at Work. New York: Oxford University Press, 198 Madison Avenue, New York, NY 10016.

Chen, Y. M., Chen, S. H., Tsai, C. Y., \& Lo, L. Y. (2007). Role Stress and Job Satisfaction for Nurse Specialists. Journal of Advanced Nursing, 59(5), 497-509. http://dx.doi.org/10.1111/j.1365-2648.2007.04339.x

College of Nurses of Ontario. (2012). Membership Statistics Highlights 2012. www.cno.org.

Cooke, G. B., Chowhan, J., \& Brown, T. (2011). Declining versus Participating in Employer-Supported Training in Canada*. International Journal of Training and Development, 15(4), 271-289. http://dx.doi.org/10.1111/j.1468-2419.2011.00386.x

Cooper, C. L., \& Cartwright, S. (1994). Healthy Mind; Healthy Organization: A Proactive Approach to Occupational Stress. Human Relations, 47(4), 455-471. http://dx.doi.org/10.1177/001872679404700405

Denton, M., Zeytinoglu, I. U., Davies, S., \& Lian, J. (2002). Job Stress and Job Dissatisfaction of Home Care Workers in the Context of Health Care Restructuring. International Journal of Health Services, 32(2), 327-357. http://dx.doi.org/10.2190/VYN8-6NKY-RKUM-L0XW

Dysvik, A., \& Kuvaas, B. (2008). The Relationship between Perceived Training Opportunities, Work Motivation and Employee Outcomes. International Journal of Training and Development, 12(3), 138-157. http://dx.doi.org/10.1111/j.1468-2419.2008.00301.x

Fairbrother, K., \& Warn, J. (2003). Workplace Dimensions, Stress and Job Satisfaction. Journal of managerial psychology, 18(1), 8-21. http://dx.doi.org/10.1108/02683940310459565

Gazioglu, S., \& Tansel, A. (2006). Job satisfaction in Britain: individual and job related factors. Applied Economics, 38(10), 1163-1171. http://dx.doi.org/10.1080/00036840500392987

Georgellis, Y., \& Lange, T. (2007). Participation in Continuous, On-the-Job Training and the Impart on Job Satisfaction: Longitudinal Evidence from the German Labour Market. International Journal of Human Resource Management, 18(6), 969-985. http://dx.doi.org/10.1080/09585190701321112

Graham, J., Ramirez, A. J., Finlay, I., Hoy, A., \& Richards, M. A. (1996). Job stress and satisfaction among palliative physicians. Palliative Medicine, 10(3), 185-194.

Jones, M. K., Jones, R. J., Latreille, P. L., \& Sloane, P. J. (2009). Training, Job Satisfaction, and Workplace Performance in Britain: Evidence from WERS 2004. LABOUR, 23, 139-175. http://dx.doi.org/10.1111/j.1467-9914.2008.00434.x

Judge, T. A., Ilies, R., \& Zhang, Z. (2012). Genetic Influences on Core Self-evaluations, Job Satisfaction, and Work Stress: A Behavioral Genetics Mediated Model. Organizational Behavior and Human Decision Processes, 117(1), 208-220. http://dx.doi.org/10.1016/j.obhdp.2011.08.005

Judge, T. A., Thoresen, C. J., Bono, J. E., \& Patton, G. K. (2001). The Job Satisfaction-Job Performance Relationship: A Qualitative and Quantitative Review. Psychological Bulletin, 127(3), 376-407. http://dx.doi.org/10.1037/0033-2909.127.3.376

Lu, H., Barriball, K. L., Zhang, X., \& While, A. E. (2012). Job satisfaction among hospital nurses revisited: A systematic review. International Journal of Nursing Studies, 49(8), 1017-1038. http://dx.doi.org/10.1016/j.jinurstu.2011.11.009

Paige, J. T. (2010). Surgical Team Training: Promoting High Reliability with Nontechnical Skills. Surgical Clinics of North America, 90(3), 569-581. http://dx.doi.org/10.1016/j.suc.2010.02.007

Podsakoff, P. M., MacKenzie, S. B., Lee, J. Y., \& Podsakoff, N. P. (2003). Common Method Biases in Behavioral Research: A Critical Review of the Literature and Recommended Remedies. Journal of Applied Psychology, 88(5), 879-903.

Ramirez, A. J., Graham, J., Richards, M. A., Cull, A., \& Gregory, W. M. (1996). Mental health of hospital consultants: The effects of stress and satisfaction at work. Lancet, 347(9003), 724-728. http://dx.doi.org/10.1016/S0140-6736(96)90077-X

Roulin, M. J., Boul'ch, M. F., \& Merlani, P. (2012). Staff satisfaction between 2 models of care for the chronically critically ill. Journal of Critical Care, 27(4), 8. http://dx.doi.org/10.1016/j.jcrc.2011.12.019 
Ruotsalainen, J., Serra, C., Marine, A., \& Verbeek, J. (2008). Systematic review of interventions for reducing occupational stress in health care workers. Scandinavian Journal of Work Environment \& Health, 34(3), 169-178. http://dx.doi.org/10.5271/sjweh.1240

Schmidt, K. H., \& Diestel, S. (2011). Differential effects of decision latitude and control on the job demands-strain relationship: A cross-sectional survey study among elderly care nursing staff. International Journal of Nursing Studies, 48(3), 307-317. http://dx.doi.org/10.1016/j.ijnurstu.2010.04.003

Sparks, K., \& Cooper, C. L. (1999). Occupational Differences in the Work-Strain Relationship: Towards the Use of Situation-Specific Models. Journal of Occupational and Organizational Psychology, 72(2), 219-229. http://dx.doi.org/10.1348/096317999166617

Spector, P. E. (1997). Job Satisfaction: Application, Assessment, Cause and Consequences. London, UK: Sage Publications.

Sullivan, S. E., \& Bhagat, R. S. (1992). Organizational Stress, Job Satisfaction and Job Performance: Where Do We Go From Here? Journal of Management, 18(2), 353-374. http://dx.doi.org/10.1177/014920639201800207

Teo, C., \& Waters, L. (2002). The Role of Human Resource Practices in Reducing Occupational Stress and Strain. International Journal of Stress Management, 9(3), 207-226. http://dx.doi.org/10.1023/A:1015575910080

Tetrick, L. E., \& Larocco, J. M. (1987). Understanding, Prediciton, and Control as Moderators of the Relationship Between Perceived Stress, Satisfaction, and Psychological Well-being. Journal of Applied Psychology, 72(4), 538-543. http://dx.doi.org/10.1037/0021-9010.72.4.538

Traut, C. A., Larsen, R., \& Feimer, S. H. (2000). Hanging on or fading out? Job satisfaction and the long-term worker. Public Personnel Management, 29(3), 343-351. http://dx.doi.org/10.1177/009102600002900304

Tzeng, H. M. (2004). Nurses' self-assessment of their nursing competencies, job demands and job performance in the Taiwan hospital system. International Journal of Nursing Studies, 41(5), 487-496. http://dx.doi.org/10.1016/j.jinurstu.2003.12.002

Tzeng, H. M., Ketefian, S., \& Redman, R. W. (2002). Relationship of nurses' assessment of organizational culture, job satisfaction, and patient satisfaction with nursing care. International Journal of Nursing Studies, 39(1), 79-84. http://dx.doi.org/10.1016/S0020-7489(00)00121-8

Utriainen, K., \& Kyngas, H. (2009). Hospital Nurses' Job Satisfaction: A Literature Review. Journal of Nursing Management, 17(8), 1002-1010.

West, E., Mays, N., Rafferty, A. M., Rowan, K., \& Sanderson, C. (2009). Nursing resources and patient outcomes in intensive care: A systematic review of the literature. International Journal of Nursing Studies, 46(7), 993-1011. http://dx.doi.org/10.1016/j.ijnurstu.2007.07.011

Wrenn, K., Lorenzen, B., Jones, I., Zhou, C., \& Aronsky, D. (2010). Factors affecting stress in emergency medicine residents while working in the ED. American Journal of Emergency Medicine, 28(8), 897-902. http://dx.doi.org/10.1016/j.ajem.2009.05.001

Zeytinoglu, I. U., Denton, M., Davies, S., Baumann, A., Blythe, J., \& Boos, L. (2007). Associations between Work Intensification, Stress and Job Satisfaction: The Case of Nurses in Ontario. Relations Industrielles-Industrial Relations, 62(2), 201-225. http://dx.doi.org/10.7202/016086ar

Zeytinoglu, I. U., Denton, M., Davies, S., Baumann, A., Blythe, J., \& Higgins, A. (2005). Survey Results of the New Health Care Worker Study: Implications of Changing Employment Patterns (Social and Economic Dimensions of an Aging Population (SEDAP) ed.): Research Paper No. 129, http://socserv2.mcmaster.ca/sedap (assessed May 25, 2013).

Zeytinoglu, I. U., Denton, M., Davies, S., Higgins, A., Blythe, J., \& Baumann, A. (2002). The New Health Care Worker Questionnaire. Andrea Baumann as the PI, funded by the CIHR under the New Health Care Worker research project.

Zeytinoglu, I. U., Denton, M., Plenderleith, J., \& Chowhan, J. (2015). Associations between workers' health, and non-standard hours and insecurity: the case of home care workers in Ontario, Canada. The International Journal of Human Resource Management, 1-20. http://dx.doi.org/10.1080/09585192.2014.1003082

\section{(cc) BY}

This work is licensed under a Creative Commons Attribution 3.0 License. 


\title{
The Influence of Leadership Styles on Organizational Commitment: The Moderating Effect of Emotional Intelligence
}

\author{
Ali Hussein Alkahtani \\ Correspondence: Ali Hussein Alkahtani, King Abdul Aziz University, P.O. Box 80201, Jeddah, 21589 Saudi Arabia
}

Received: September 15, 2015 Accepted: September 28, 2015 Online Published: October 10, 2015

doi:10.11114/bms.v2i1.1091

URL: http://dx.doi.org/10.11114/bms.v2i1.1091

\begin{abstract}
Organizations need employees who are committed in their work so that they can contribute to the survival of the organization in the marketplace competition. Organizational commitment can be divided into three components; normative, affective and continuance commitment. There are various factors that influence employees' commitment. These factors can be categorized into four groups; organizational factors, including leadership, culture, structure and processes; individual factors, including personality traits, emotional quotient, intellectual quotient, and spiritual quotient; job factors, including job characteristics, and remuneration systems; and environment factors, including social relationships and physical environment. This paper is meant to discuss on the influence of the most dominant organizational factor; leadership styles, on employees' organizational commitment by concentrating on the effect of leaders' emotional intelligence. Leadership styles are hypothesized to significantly influence the three types of employees' organizational commitment. Besides, leaders' emotional intelligence is hypothesized to enhance the relationship between leadership styles and employees' organizational commitment. The practical and research implications of the paper are also discussed.
\end{abstract}

Keywords: leadership styles, organizational commitment, emotional intelligence

\section{Introduction}

\subsection{Background of the Study}

Organizational commitment is a common phenomenon which has been extensively addressed by many researchers worldwide due to its importance to the organization (e.g. Angle \& Perry, 1981; Kim, 2001; Lio \& Nyhan, 1994; Lo, Ramayah, \& Min, 2009). Organizational commitment has been linked to the performance of organizational constituents, their loyalty, organizational citizenship behavior, counterproductive behavior, employees' aggression, job satisfaction, and other individual and group constructs. Committed employees are expected to perform at a greater level than their uncommitted counterparts (Meyer, Paunonen, Gellatly, Goffin, \& Jackson, 1989). They are willing to work extra hours when the job requires them to do so. They are also willing to promote the organization as a favorable place to work at. Due to its diverse accrued benefits to the organization, some researchers have devoted their effort to investigate the antecedents of organizational commitment (e.g. Bateman \& Strasser, 1984; Lok \& Crawford, 2004; Meyer, Allen, \& Smith, 1993). These factors can be categorized into four groups; organizational factors, including leadership, culture, structure and processes; individual factors, including personality traits, emotional quotient, intellectual quotient, and spiritual quotient; job factors, including job characteristics, and remuneration systems; and environment factors, including social relationships and physical environment. The focus of this paper is on the influence of leadership styles on employees' organizational commitment.

Leadership style is the most prevalent factors that influence employees' attitudes and behaviors including organizational commitment. Leaders have adopted various styles when they lead others in the organization (Brown, 2003; Cheong, 2008; Chiang \& Wang, 2012; Clark, Hartline, \& Jones, 2009; Cox, 2001). Some are using democratic, people or relationship centered approach and others prefer autocratic, production centered method in order to achieve a similar goal, which is organizational effectiveness. The choice of a style is contingent on diverse factors such as personality traits of leaders, followers' acceptance of the leaders, their readiness, task complexity and the norms and values embraced by the organizational members. Therefore, leaders must possess special ability to diagnose the organizational environment, accurately identify the contingent factors and subsequently make a sound decision in leading the organization towards success. Here, emotional intelligence ability offers great help to guide a leader in choosing the 
right leadership styles.

Emotional intelligence is a set of abilities to accurately assess the emotions of self and others, regulate the emotions to achieve the desired state and use the emotions towards achieving the expected performance (Mayer \& Salovey, 1997). Emotional intelligence has been defined differently by different authors but the objective of having this intelligence is similar; to achieve the desired emotional state so that the employees are able to attain their expected performance. Leaders with high emotional intelligence are able to correctly scan the organizational environment, weigh the possible consequences of their actions and select the most appropriate leadership styles acceptable by the followers. This paper is meant to highlight the critical role of emotional intelligence in influencing leaders' choice of styles and its relationship with employees' organizational commitment, which comprises normative, affective and continuance commitment. Existing work in this area is discussed and relevant propositions are formulated to facilitate the future effort towards the enrichment of the related knowledge.

\subsection{Organizational Commitment}

The common definition of commitment does not really exist (Morris \& Steers, 1993) because different authors provide different definitions for the construct. Mowday, Porter and Steers (1982) defined commitment as the relative strength of an individual's identification with an organization and involvement in the organization. In some cases a distinction is made between organizational commitment and task commitment (Peeters \& Meijer, 1995). Gallie and White (1993) asserted that the term "organizational commitment" refers to the acceptance of organizational values and the willingness to stay. Task commitment, on the other hand, reflects the effort one puts into his or her work. Porter, Steers, Mowday, \& Boulian (1974) and Mowday, Steers and Porter (1979) defined organizational commitment as a strong belief in the organization and willingness to exert significant effort towards the organization. Commitment to organization is linked to very important work-related factors such as employee absenteeism, employee turnover and employee job performance (Mowday, Porter, \& Dubin, 1974; Mowday, Steers \& Porter, 1979; Romzek, 1990; Ward \& Davis, 1995).

Organizational commitment is categorized into three components; affective, continuance and normative commitments (Allen \& Meyer, 1990; 1996). Affective commitment concerns the employee's emotional attachment to, identification with and involvement in the organization. Affective commitment involves three aspects: (1) the formation of an emotional connection to an organization, (2) identification with an organization (3) and the desire to maintain and become loyal with organizational membership. Affective commitment exists when an employee identifies with an organization and its goals (Mowday, et al., 1979). Allen and Meyer (1997) said that employees retain to be members of the organization and try to increase their productivity.

Continuance commitment, on the other hand, refers to employees' assessment of whether the costs of leaving the organization are greater than the costs of staying. Employees who perceive that the costs of leaving the organization are greater than the costs of staying will remain with the organization. In contrast to the other two components of organizational commitment, continuance commitment does not relate to emotion. It mostly relates to the investments the employees make in an organization such as job effort, time and development with work friendships, skills and political deals (Jaros, Jermier, Koehler, \& Sincich, 1993). Allen and Meyer (1990) enumerated the concept of continuance commitment as a form of psychological attachment to an employing organization that reflects the degree to which an individual experiences a sense of being locked in place because of high cost of leaving.

Normative commitment refers to employees' feelings of responsibility to the organization. Employees with high levels of normative commitment stay with the organization because they feel that they have to. In arguing for their framework, Meyer and Allen (1991) contended that affective, continuance, and normative commitment were components rather than types because employees could have varying degrees of all three. They exemplified the three types of commitment by saying that one employee might feel both a strong attachment to an organization and a sense of responsibility to remain. A second employee might enjoy working for the organization but also recognize that leaving would be very difficult from an economic perspective. Finally, a third employee might experience a considerable degree of desire, need, and responsibility to remain with the current employer (Allen \& Meyer, 1997). According to Randall and O'driscoll (1997), normative commitment is an employees' moral commitment that is present when an organization provides moral value and financial support for its employees' development and requirement.

\subsection{Leadership Styles}

Leadership style is the approach of providing direction, implementing plans, and motivating people (Northouse, 2015). Leaders should identify the best leadership style to manage their employees in the organization. Harry S. Truman, $33^{\text {rd }}$ President of the United States once said, "A leader is a man who can persuade people to do what they do not want to do, or do what they are too lazy to do". Leadership is a process, involves influence, occurs within a group contact, and involves goal attainment. Using this claim, leadership is defined as a process where an individual influences a group of other individuals to achieve a common goal. In other words, the leader is the inspiration and director of the action. He 
or she is the person in the group that possesses the combination of personality and skills that make others want to follow his or her direction. In business, leadership is strongly linked to performance. Effective leaders are those who are able to increase their company's bottom lines.

Leadership is very important in order to manage and control employees and organizations. The suitability of leadership styles to be used in an organization is based on the sector of business in which they are operating. An effective leader is someone who knows how to inspire and relate to subordinates, knows how to increase the employees' motivation and make employees loyal to the organization. The most universal leadership styles concerns transactional, transformational and laissez-faire. These three styles are commonly applied in various organizations nowadays. Transactional leadership is about power to perform certain tasks and reward or punish according to employees' performance. If employees perform well, the leader will reward them, but if their performance is not as expected, they will be punished. In transformational leadership, leaders show the value of workers concentrating on what benefits their work team can achieve rather than on individual interests, they know how to motivate employees, know how to read them and know how to handle them. In laissez-faire leadership style, leaders have minimum involvement in decision making. They allow employees to make their own decisions but they are still responsible for the outcome. Laissez-faire works best when people are capable and motivated in making their own decision and opinion. The employees are confident and there is no requirement for central coordination.

\subsubsection{Transformational versus Transactional Leadership Styles}

Previous studies have established that transformational leadership is the most preferred by employees in organizations. According to Burns (1978), transformational leadership links the power of a position to respond to the needs of the followers. In this style, the vision of the leader must be conveyed to the follower. This vision sometimes requires change in the organization. This style is becoming increasingly important because of the demand for the organization to change in today's world of globalization. It is important for transformational leaders to motivate the followers regarding their vision.

Transformational leaders motivate followers to be better in many ways (Avolio \& Bass, 1988; Burns, 1978). The leaders concentrate on teamwork rather than individual interests. Transformational leadership clearly defines the roles of the leader and followers but also includes the followers in the leadership process. Effective leadership requires leading others to think innovatively and promoting the continual discovery of new solutions to the problems that they are facing. To get people to work toward a common goal is not easy. Research suggests that leaders need to have qualities that facilitate followers to transform from one situation to another and they are transformational (Shamir, House, \& Arthur, 1993; Yukl, 1999). Transformational leadership can motivate employees to go beyond their own self-interest and pursue goals and encourage employees to become more productive. Transformational leadership encourages followers to accomplish more than what would normally be expected of them and they are motivated to relinquish their own interest for the good of employees or organization (Barnett, McCormick, \& Conners, 2001; Bass \& Avolio, 1997; Northhouse, 2015).

Transformational leadership is also defined in terms of how the leader affects followers, who are intended to trust, admire and respect the leader (Bass \& Steidlmeier, 1998). But for laissez-faire style, the involvement of leaders in decision-making is minimal and hence allows people to make their own decisions, although the leaders are still responsible for the outcome. The transactional leadership style was first described by Max Weber in 1947, and again by Bernard M. Bass in 1985. Transformational leadership is the one end of leadership spectrum and transactional leadership is its opposite end. There is no single method which has been found to be successful in all situations (Bass, $1985 ; 1997 ; 1998)$. However, the focus of leadership has shifted from transactional models of leadership to new genre of leadership theories by highlighting on transformational leadership (Bass, 1985). Transformational leadership can be divided into four factors;

\section{1) Idealized Influence}

Idealized influence is the behavior that encourages the followers to use their leaders as role models. Idealized influence leaders have high moral and ethical values and are able to provide their followers with a sense of vision and mission. In most situations, followers greatly respect the idealized influence leader (Northouse, 2001).

\section{2) Individualized Consideration}

Individualized consideration is shown by the transformational leader by creating a supportive climate, listening to their employees, and acts as a coach and mentor which the leaders show consideration for their employees' needs. Leaders pay close attention to individual differences and treat their employees in the most caring way. Leaders also help individuals to achieve goals and personal development. This type of leaders also uses delegation to get their employee to grow through personal challenges (Northouse, 2015). 


\section{3) Inspirational Motivation}

Inspirational motivation is about raising the consciousness of the employees by motivating and inspiring them to demonstrate commitment to the vision and mission of the group in the organization. The inspirational motivational leaders engage in clearly communicating high expectations to followers and increase team spirit and enthusiasm (Northouse, 2015).

\section{4) Intellectual Stimulation}

Intellectual stimulation is demonstrated by the leaders when they support their employees to be creative and innovative and to try new approaches and challenge their own beliefs and values. This type of leaders promotes problem solving to find creative solutions (Northouse, 2015).

Transactional leadership concerns the power to perform certain tasks and reward or punish for employees' performance (Burns, 1978). It gives the opportunity to leaders to lead the employees and they agree to follow their leaders to accomplish the goals. Power is given to the leaders to evaluate, train and correct and handle the employees when productivity is below the expectation level and reward appropriately when the expected outcome is reached. However, findings of the previous studies on transactional leadership show mixed results. Reward leadership has been found in many cases to be highly correlated to transformational leadership (Avolio, Bass, \& Jung, 1999). In general, active leadership is found to be more effective than passive leadership. However, Howell and Avolio (1993) argued that if the predominant style of the leader is to take corrective action, such behavior is expected to have a negative impact on followers' performance. There are three factors in transactional leadership style which are;

\section{1) Contingent Reward}

Managers who use the contingent reward leadership show the standards, and encourage their employees to perform well because the leaders will let their employees know the rewards they will receive if their performance level is high. Subordinates are promised rewards for good performance but if the performance is bad they will receive the punishment (Bass, 1985; Avolio, et al., 1999).

\section{2) Management by Exception (Active)}

Management-by-Exception (active) occurs when leaders make corrective criticisms or use negative reinforcement. This leadership behavior monitors employees closely in order to identify mistakes and errors. Leaders with Management-byException with "active" behaviors are characterized as monitoring followers' performances and taking corrective action if deviations from the set standards occur. These leaders enforce rules to avoid mistakes.

3) Management by Exception (passive)

In this leadership style, leaders use Management-by-Exception (passive), only intervene when goals have not been met or a problem arises. The Management-by-Exception leader with a "passive" behavior would not get involved until problems become serious. The Management-by-Exception (passive) leaders wait to take action until mistakes are brought to their attention. Laissez-faire behaviors normally involve the postponement of decisions and capitulation of responsibility. Laissez-faire leaders offer no feedback or support to the follower. Laissez-faire leadership is a "hands-off" approach to leadership (Northouse, 2015).

\subsection{The Relationship between Transformational Leadership Styles and Organizational Commitment}

Previous research has devoted a great deal of attention to the relationship between leadership behavior and employees' commitment. Several studies found a positive relationship between the two variables (Kent \& Chelladurai, 2001; Leach, 2005; Pearce \& Herbik, 2004). According to Stum (1999), employees' commitment reflects the quality of the leaderships styles used in the organization. Thus, it is logical to think that leadership behavior would have a significant correlation or relationship with employees' commitment. Previous research suggests a positive direct relationship between leadership behaviors and employees' commitment.

Morris and Steers (1993) Ananthi and Subramaniam (2011) have established the link between leadership behavior and employees' commitment. Brief, Aldag and Wallden, (1976), investigated police officers' commitment and found high positive relationship between respect for their supervisors and organizational structuring level. Den Hartog and Belschak (2012), Hill, Seo, Kang, and Taylor (2012) and Mowday, et al. (1982) also found that there was a positive relationship between leader's behavior and employees' commitment. Lee (2008) found out that transformational leadership significantly correlates with employees' commitment with the sample of professionals in Singapore. On the other hand, Hayward, Goss and Tolmay (2004) noted that transformational leadership has moderate positive correlation with affective commitment. Besides, the researcher also found that there is a lower correlation between transformational leadership, normative and continuance commitment.

Billingsley and Cross (1992) reported a positive relationship between leader support and commitment. In three separate 
studies, Popper, Mayseless and Castelnovo (2000) found evidence supporting a positive correlation between transformational leadership and attachment. Podsakoff, MacKenzie and Bommer (1996) found that leadership behaviors explained $48 \%$ of the variance in organizational commitment. Kent and Chelladurai (2001) found that individualized consideration has positive correlation with both affective commitment and normative commitment. Besides, the researchers also found positive correlations between intellectual stimulation and both affective commitment and normative commitment.

Shamir, House and Arthur (1993) and Shamir, Zakay, Breinin and Popper (1998) suggest that transformational leaders are able to influence followers' organizational commitment by promoting higher levels of intrinsic value associated with goal accomplishment, emphasizing the linkages between followers' effort and goal achievement, and by creating a higher level of personal commitment on the part of the leader and followers to a common vision, mission and organizational goals. Transformational leaders influence followers' organizational commitment by encouraging them to think critically by using novel approaches, involving followers in decision-making processes and inspiring loyalty while recognizing and appreciating the different needs of each follower to develop his or her personal potential (Bass \& Avolio, 1994; 1997; Yammarino, Spangler \& Bass, 1993). By encouraging followers to seek new ways to approach problems and challenges and identifying with followers' needs, transformational leaders are able to motivate their followers to get more involved in their work, resulting in higher levels of organizational commitment (Walumbwa \& Lawler, 2003). This view was supported by prior research showing that organizational commitment was higher for employees whose leaders encouraged participation in decision-making (Jones \& Rudd, 2008; Scott-Ladd, Travaglione, \& Marshall, 2006), emphasized on consideration (Bycio, Hackett \& Allen, 1995) and were supportive and concerned for their followers' development (Allen \& Meyer, 1990; 1996; 1997)

Other researchers, Kent and Chelladurai (2001) stated that individualized consideration has positive relationship with both affective commitment and normative commitment. Other than that, the researcher also found that there is positive correlation between intellectual stimulation and both affective commitment and normative commitment. Bass and Avolio (1994) discovered that transformational leaders who encourage their followers to think critically and creatively have an influence on their followers' commitment. This is further supported by Walumbwa and Lawler (2003) that transformational leaders can motivate and increase followers' motivation and organizational commitment by getting them to solve problems creatively and also understanding their needs. Ko, Price and Mueller (1997) further suggested that employees are far more likely to be committed to the organization if they have confidence in their leaders. Hence, the appropriate propositions are formulated as follow:

P1 Idealized influence leaders have positive influence on employees' affective commitment

P2 Individualized consideration leaders have positive influence on employees' affective commitment

P3 Inspirational motivational leaders have positive influence on employees' affective commitment

P4 Intellectual stimulation leaders have positive influence on employees' affective commitment

P5 Idealized influence leaders have positive influence on employees' continuance commitment

P6 Individual consideration leaders have positive influence on employees' continuance commitment

P7 Intellectual stimulation leaders have positive influence on employees' continuance commitment

P8 Inspirational motivational leaders have positive influence on employees' continuance commitment

P9 Idealized influence leaders have positive influence on employees' normative commitment

P10 Individual consideration leaders have positive influence on employees' normative commitment

P11 Intellectual stimulation leaders have positive influence on employees' normative commitment

P12 Inspirational motivational leaders have positive influence on employees' normative commitment

\subsection{The Relationship between Transactional Leadership Style and Organizational Commitment}

Transactional leadership has been found to have significant relationship with organizational commitment but it is a weak relationship (Alqudah, 2011). Brown and Dodd (1999) earlier claimed that transactional leadership has a negative association with affective, normative and continuance commitment. Based on this premise, the following propositions are constructed:

P13 Contingent reward leaders have negative influence on employees' affective commitment

P14 Management-by-Exception leaders have negative influence on employees' affective commitment

P15 Contingent reward leaders have negative influence on employees' continuance commitment

P16 Management-by-Exception leaders have negative influence on employees' continuance commitment 
P17 Contingent reward leaders have negative influence on employees' normative commitment

P18 Management-by-Exception leaders have negative influence on employees' normative commitment

\subsection{Definitions of Emotional Intelligence}

An early definition of Emotional Intelligence (EI) by Salovey and Mayer (1990, p. 189) describes it as the subset of social intelligence that involves the ability to monitor one's own and others' feelings and emotions to discriminate among them and to use this information to guide one's thinking and actions. Building on Salovey and Mayer's work, Goleman (2000) identified the abilities that EI involves and categorized these EI competencies into five areas; self-awareness, self-regulation, self-motivation, empathy and social competencies. EI is demonstrated when a person uses competencies that constitute self-awareness, self-management, social-awareness, and social skills at the right times, in the correct ways and in sufficient frequency to be effective in the situation (Boyatzis, Goleman, \& Rhee, 2000). The emotional competence inventory (ECI), developed by Boyatzis, Goleman and others, uses four clusters; self-awareness, social awareness, self-management and social skills.

Emotional Intelligence reflects people's or leaders' ability to do their jobs well, the degree of employees' flexibility in doing their jobs, ability to innovate and ownership of and responsibility for their work and the level of the performance standards. Emotionally intelligent leaders have been found to contribute to increased individual and organizational performance (Carmeli, 2003; Nikolaou \& Tsaousis, 2002; Parasuraman \& Nachman, 1987; Weinberger, 2003; Wong \& Law, 2002). It also has been linked with increased organizational effectiveness performance (Cherniss \& Goleman, 2001). Prati, Douglas, Ferris, Ammeter and Buckley (2003) developed a model connecting emotional intelligence with leadership, team process and outcomes. The model highlights emotional intelligence abilities as the key for effective team leadership and successful team outcomes. The relationship between leadership styles used by leaders and employees' organizational commitment can be moderated by the extent of emotional intelligence the leaders have. According to Mohamadkhani and Nasiri Lalardi (2012), there is a highly significant relationship between emotional intelligence and organizational commitment where emotional intelligence of leaders increases employees' organizational commitment.

\subsection{Emotional Intelligence (EI) and Leadership Styles}

A significant relationship between emotional intelligence competencies and individual performance has been established for some time (Boyatzis, 1982). Emotionally intelligent managers or leaders have been found to contribute to increased individual and organizational performance (Carmeli, 2003; Nikolaou \& Tsaousis, 2002; Parasuraman \& Nachman, 1987; Weinberger, 2003; Wong \& Law, 2002). Emotional intelligence has been linked to increased organizational effectiveness across a broad range of areas (Cherniss \& Goleman, 2001). Those with high emotional intelligence are more likely to be able to become effective leaders (Goleman, 2000). Goleman, Boyatzis and McKee (2002) have demonstrated a clear link between emotional intelligence, leadership style and organizational performance. The importance of the leadership style has been researched and discussed widely, including the link between leadership style and emotional intelligence (Mandell \& Pherwani, 2003; Turner \& Müller, 2005; Turner \& Lloyd-Walker, 2008). Mandell and Pherwani (2003) found a significant relationship between transformational leadership style and emotional intelligence of leaders. Prati, et al. (2003) developed a model linking emotional intelligence, leadership, team processes and outcomes. Prati, et al. (2003) claimed that emotional intelligence abilities are critical for effective team leadership and successful team outcomes.

\subsubsection{Emotional Intelligence and Transformational Leadership}

Emotional Intelligence supports the improvement of a transformational leadership style, and the combination of transformational leadership style and emotional intelligence abilities have the potential to improve project outcome (Leban \& Zulauf, 2004). Butler and Chinowsky (2006) studied the relationship between emotional intelligence and transformational leadership styles of project managers in the construction industry. They found that interpersonal skills and empathy are key emotional intelligence behaviors required by construction industry executives if the industry is to achieve more successful project outcomes in the future. The positive relationship between emotional intelligence and transformational leadership has also been established by other researchers (Barbuto \& Burbach, 2006).

Goleman, et al. (2002) introduced the concept that emotional intelligence is not only a power enhancer, but it is also an essential component of successful leadership. Goleman, et al.'s (2002) model of emotional intelligence identifies four critical domains, which are broken down into 18 competencies. The model demonstrates that the leadership skills which contribute to leader success require the inclusion of emotional intelligence abilities. Leader attributes include a range of interpersonal skills are closely linked to emotional intelligence abilities; listening, empathy and awareness (Greenleaf, 2003); influencing skills, developing, coaching and nurturing (Maccoby, 2000) developing plans, setting goals and demonstrating strong emotional self-management (Humphrey, 2002) and self-control (Goleman, et al., 2002). 
To sum up the discussion, the following propositions are emphasized:

P19 Emotional Intelligence enhances the influence of idealized influence leaders on employees' affective commitment

P20 Emotional Intelligence enhances the influence of inspirational motivational leaders on employees' affective commitment

P21 Emotional Intelligence enhances the influence of intellectual stimulation leaders on employees' affective commitment

P22 Emotional Intelligence enhances the influence of individualized consideration leaders on employees' affective commitment

P23 Emotional Intelligence enhances the influence of idealized influence leaders on employees' continuance commitment

P24 Emotional Intelligence enhances the influence of inspirational motivational leaders on employees' continuance commitment

P25 Emotional Intelligence enhances the influence of intellectual stimulation leaders on employees' continuance commitment

P26 Emotional Intelligence enhances the influence of individualized consideration leaders on employees' continuance commitment

P27 Emotional Intelligence enhances the influence of idealized influence leaders on employees' normative commitment

P28 Emotional Intelligence enhances the influence of inspirational motivational leaders on employees' normative commitment

P29 Emotional Intelligence enhances the influence of intellectual stimulation leaders on employees' normative commitment

P30 Emotional Intelligence enhances the influence of individualized consideration leaders on employees' normative commitment

\subsubsection{Emotional Intelligence and Transactional Leadership}

Emotional Intelligence supports certain transactional leadership when the leaders use the contingent reward characteristic in order to inspire and motivate employees to perform well. According to Bass (1985) and Bass and Avolio (1997), transactional leadership can be described in terms of two characteristics: the use of contingent rewards and management by exception. They described contingent reward as the reward that the leader will present to the employees once the latter have achieved goals that were agreed upon. Contingent reward is therefore the exchange of rewards for meeting agreed-upon objectives. By combining the transactional leadership and emotional intelligence, the employees will be more committed to their job and increase their job performance. With emotional intelligence abilities, transactional leaders are more able to make and fulfill promises by rewarding employees appropriately and relate the reward given to the employees' performance.

Bass (1985) argues that by providing the contingent rewards, a transactional leader might inspire a reasonable degree of involvement, loyalty, commitment and performance from subordinates. Transactional leaders may also rely on active management by exception which occurs when the leader monitors followers to ensure mistakes are not made, but otherwise, allows the status quo to exist without being addressed (Bass \& Avolio, 1995). In passive management by exception, the leader intervenes only when things go wrong. Coupled with emotional intelligence abilities, transactional leaders are able to make better decisions as to when and how to intervene, to what extent and with whom the intervention should be exercised. It is because the leaders become more sensible to the situations and the needs and readiness of the employees.

Based on the above discussion, the following propositions are highlighted:

P31 Emotional intelligence enhances the positive influence of contingent reward leaders on employees' affective commitment

P32 Emotional intelligence enhances the positive influence of management by exception leaders on employees' affective commitment

P34 Emotional intelligence enhances the positive influence of contingent reward leaders on employees' continuance commitment

P35 Emotional intelligence enhances the positive influence of management by exception leaders on employees' 
continuance commitment

P36 Emotional intelligence enhances the positive influence of contingent reward leaders on employees' normative commitment

P38 Emotional intelligence enhances the positive influence of management by exception leaders on employees' normative commitment

\section{Conclusion}

The review of the existing studies on leadership found that all dimensions of transformational leadership styles; idealized influence, inspirational motivation, intellectual stimulation and individualized consideration, are significantly related to employees' organizational commitment dimensions; continuance, affective and normative. Transactional leadership styles that consist of contingent reward, management by exception (passive) and management by exception (active) are weakly related to the three dimensions of organizational commitment. However, leaders with high emotional intelligence abilities are hypothesized to enhance the relationship between transformational leadership styles and organizational commitment and change the direction of the relationship between transactional leadership styles and organizational commitment of employees in the organization.

\subsection{Managerial Implications}

Leaders in today's globalized business environment characterized by rapid change should be equipped with emotional intelligence abilities so that they are able to effectively exercise their leadership roles. Leadership styles are very much contingent on the organizational environment, thus, rendering none of the leadership style as superior than the other. The emotional intelligent ability of the leaders is crucial to ensure that the leadership styles chosen by the leaders can be executed effectively to enhance the employees' organizational commitment. Emotional intelligence of leaders can be gradually developed through individual reflective exercises where the leaders assess their emotional states as a result of various emotional stimulating events. It can also be developed through frequent observation and assessment of others' emotional states. Besides, it can also be nurtured by continuously applying appropriate strategies to deal with negative as well as positive emotions. These strategies can range from suppressing to amplifying the desired emotions so that the energy emerged from these emotions can be manipulated to stimulate leaders to engage in productive activities. To sum up, emotional intelligence is crucial for leaders to effectively lead others in the organization to achieve the organizational objectives.

\subsection{Suggestions for Future Research}

This paper attempts to integrate the concept of emotional intelligence into the relationship between leadership styles and employees' organizational commitment. The suggested conceptual framework is worthless without the effort to confirm the highlighted propositions using empirical evidence. Thus, future research in this area is highly warranted using the most reliable and valid research instruments and utilizing rigorous methodology and data analysis. It is worth noted that there are abundant of available research instruments relating to the discussed constructs, thus, researchers' discretion is highly required in the selection of the correct ones considering the costs and benefits accrued from using each of them. With correct methodology and data analysis the findings can be generalized across different settings and the existing model can be further enhanced.

\section{References}

Allen, N. J., \& Meyer, J. P. (1990). The measurement and antecedents of affective, continuance and normative commitment to the organization. Journal of Occupational Psychology, 63(1), 1-18. http://dx.doi.org/10.1111/j.2044-8325.1990.tb00506.x

Allen, N. J., \& Meyer, J. P. (1996). Affective, continuance, and normative commitment to the organization: An examination of construct validity. Journal of Vocational Behavior, 49(3), 252-276. http://dx.doi.org/10.1006/jvbe.1996.0043

Allen, N. J., \& Meyer, J. P. (1997). Commitment in the workplace: Theory, research and application. Thousand Oaks, CA: Sage Publications.

Alqudah, T. G. (2011). Leadership styles and organizational commitment. (Master of Business Administration Dissertation, Open University Malaysia).

Ananthi, P., \& Subramaniam, B. (2011). The influence of leadership styles on organizational commitment. (Master Thesis, University Utara Malaysia).

Angle, H. L., \& Perry, J. L. (1981). An empirical assessment of organizational commitment and organizational effectiveness. Administrative Science Quarterly, 26(1), 1-14. http://dx.doi.org/10.2307/2392596 
Avolio, B. J., \& Bass, B. M. (1988). Transformational leadership, charisma, and beyond. In Gerald, H. J., Rajaram, B. B., Peter, D. H., \& Chester A. S. (Eds.). Emerging leadership vistas. International leadership symposia series, (pp. 29-49). Lexington, MA, England: Lexington Books.

Avolio, B. J., Bass, B. M., \& Jung, D. I. (1999). Re-examining the components of transformational and transactional leadership using the Multifactor Leadership. Journal of Occupational and Organizational Psychology, 72(4), 441-462. http://dx.doi.org/10.1348/096317999166789

Barbuto, J. E., \& Burbach, M. E. (2006). The emotional intelligence of transformational leaders: A field study of elected officials. The Journal of Social Psychology, 146(1), 51-64. http://dx.doi.org/10.3200/SOCP.146.1.51-64

Barnett, K., McCormick, J., \& Conners, R. (2001). Transformational leadership in schools-panacea, placebo or problem?. Journal of Educational Administration, 39(1), 24-46. http://dx.doi.org/10.1108/09578230110366892

Bass, B. M. (1985). Leadership and performance beyond expectations. New York, NY: Free Press.

Bass, B. M. (1997). Does the transactional-transformational leadership paradigm transcend organizational and national boundaries?. American Psychologist, 52(2), 130-139. http://dx.doi.org/10.1037/0003-066X.52.2.130

Bass, B. M. (1998). Transformational leadership: Industry, military, and educational impact. Mahwah, NJ: Erlbaum Associates.

Bass, B. M., \& Avolio, B. J. (1994). Transformational leadership and organizational culture. The International Journal of Public Administration, 17(3-4), 541-554.

Bass, B. M., \& Avolio, B. J. (1995). MLQ multifactor leadership questionnaire. Redwood City. CA: Mind Garden.

Bass, B. M., \& Avolio, B. J. (1997). Full range leadership development: Manual for the Multifactor Leadership Questionnaire (pp. 43-44). Palo Alto, CA: Mind Garden.

Bass, B. M., \& Steidlmeier, P. (1999). Ethics, character, and authentic transformational leadership behavior. The Leadership Quarterly, 10(2), 181-217. http://dx.doi.org/10.1016/S1048-9843(99)00016-8

Bateman, T. S., \& Strasser, S. (1984). A longitudinal analysis of the antecedents of organizational commitment. Academy of Management Journal, 27(1), 95-112. http://dx.doi.org/10.2307/255959

Billingsley, B. S., \& Cross, L. H. (1992). Predictors of commitment, job satisfaction, and intent to stay in teaching: A comparison of general and special educators. The Journal of Special Education, 25(4), 453-471. http://dx.doi.org/10.1177/002246699202500404

Boyatzis, R. E. (1982). The competent manager: A model for effective performance. England: John Wiley \& Sons.

Boyatzis, R. E., Goleman, D., \& Rhee, K. (2000). Clustering competence in emotional intelligence: Insights from the Emotional Competence Inventory (ECI). Handbook of Emotional Intelligence, 343-362.

Brief, A. P., Aldag, R. J., \& Wallden, R. A. (1976). Correlates of supervisory style among policemen. Criminal Justice and Behavior, 3(3), 263-271. http://dx.doi.org/10.1177/009385487600300304

Brown, B. B. (2003). Employees' organizational commitment and their perception of supervisors' relations-oriented and task-oriented leadership behaviors (Doctoral dissertation, Virginia Polytechnic Institute and State University).

Brown, F. W., \& Dodd, N. G. (1999). Rally the troops or make the trains run on time: The relative importance and interaction of contingent reward and transformational leadership. Leadership \& Organization Development Journal, 20(6), 291-299. http://dx.doi.org/10.1108/01437739910292607

Burns, J. M. (1978). Leadership. New York, NY: The Free Press.

Butler, C. J., \& Chinowsky, P. S. (2006). Emotional intelligence and leadership behavior in construction executives. $\begin{array}{llll}\text { Journal of } & \text { Management }\end{array}$ http://dx.doi.org/10.1061/(ASCE)0742-597X(2006)22:3(119)

Bycio, P., Hackett, R. D., \& Allen, J. S. (1995). Further assessments of Bass's (1985) conceptualization of transactional and transformational leadership. Journal of Applied Psychology, 80(4), 468-478. http://dx.doi.org/10.1037/0021-9010.80.4.468

Carmeli, A. (2003). The relationship between emotional intelligence and work attitudes, behavior and outcomes: An examination among senior managers. Journal of Managerial Psychology, 18(8), 788-813. http://dx.doi.org/10.1108/02683940310511881

Cheong, L. H. (2008). Investigating the impact of managerial coaching on employees' organizational commitment and turnover intention in Malaysia. (Master Dissertation, University of Malaya, Malaysia). 
Cherniss, C., \& Goleman, D. (2001). Training for emotional intelligence: A model. The emotionally intelligent workplace (209-233). San Francisco, CA: Jossey-Bass.

Chiang, C. F., \& Wang, Y. Y. (2012). The effects of transactional leadership and transformational leadership on organizational commitment in Hotels: The mediating effect of trust. Journal of Hotel and Business Management, $1(1)$.

Clark, R. A., Hartline, M. D., \& Jones, K. C. (2009). The effects of leadership style on hotel employees' commitment to service quality. Cornell Hospitality Quarterly, 50(2), 209-231. http://dx.doi.org/10.1177/1938965508315371

Cox, P. L. (2001). Transformational leadership: A success story at Cornell University. In Proceedings of the ATEM/aappa 2001 conference. Retrieved March (Vol. 17, p. 2004).

Den Hartog, D. N., \& Belschak, F. D. (2012). When does transformational leadership enhance employee proactive behavior? The role of autonomy and role breadth self-efficacy. Journal of Applied Psychology, 97(1), 194-202. http://dx.doi.org/10.1037/a0024903

Gallie, D., \& White, M. (1993). Employee commitment and the skills revolution: First findings from the Employment in Britain Survey. London: Policy Studies Institute.

Goleman, D. (2000). An EI-based theory of performance. In D. Goleman, \& C. Cherniss (Eds).The emotionally intelligent workplace: How to select for, measure, and improve emotional intelligence in individuals, groups, and organizations. San Francisco, CA: Jossey-Bass.

Goleman, D., Boyatzis, R. E., \& McKee, A. (2002). The new leaders: Transforming the art of leadership into the science of results. London: Little, Brown.

Greenleaf, R. K. (2003). Motion and emotion. Principal Leadership, 3(9), 14-19.

Hayward, Q., Goss, M., \& Tolmay, R. (2004). The relationship between transformational and transactional leadership and employee commitment. Grahamstown, Rhodes University: Business Report.

Hill, N. S., Seo, M. G., Kang, J. H., \& Taylor, M. S. (2012). Building employee commitment to change across organizational levels: The influence of hierarchical distance and direct managers' transformational leadership. Organization Science, 23(3), 758-777. http://dx.doi.org/10.1287/orsc.1110.0662

Howell, J. M., \& Avolio, B. J. (1993). Transformational leadership, transactional leadership, locus of control, and support for innovation: Key predictors of consolidated-business-unit performance. Journal of Applied Psychology, 78(6), 891-902.

Humphrey, R. H. (2002). The many faces of emotional leadership. The Leadership Quarterly, 13(5), 493-504. http://dx.doi.org/10.1016/S1048-9843(02)00140-6

Jaros, S. J., Jermier, J. M., Koehler, J. W., \& Sincich, T. (1993). Effects of continuance, affective, and moral commitment on the withdrawal process: An evaluation of eight structural equation models. Academy of Management Journal, 36(5), 951-995. http://dx.doi.org/10.2307/256642

Jones, D., \& Rudd, R. (2008). Transactional, Transformational, or Laissez-Faire Leadership: An Assessment of College of Agriculture Academic Program Leaders'(Deans) Leadership Styles. Journal of Agricultural Education, 49(2), 88-97.

Kent, A., \& Chelladurai, P. (2001). Perceived transformational leadership, organizational commitment, and citizenship behavior: A case study in intercollegiate athletics. Journal of Sport Management, 15(2), 135-159.

Kim, B. S. (2001). Commitment of Malaysian workers in Korean multinational enterprises. Malaysian Management Review, 36(1), 63-75.

Ko, J. W., Price, J. L., \& Mueller, C. W. (1997). Assessment of Meyer and Allen's three-component model of organizational commitment in South Korea. Journal of Applied Psychology, 82(6), 961-973. http://dx.doi.org/10.1037/0021-9010.82.6.961

Leach, L. S. (2005). Nurse executive transformational leadership and organizational commitment. Journal of Nursing Administration, 35(5), 228-237.

Leban, W., \& Zulauf, C. (2004). Linking emotional intelligence abilities and transformational leadership styles. Leadership \& Organization Development Journal, 25(7), 554-564. http://dx.doi.org/10.1108/01437730410561440

Lee, J. (2008). Effects of leadership and leader-member exchange on innovativeness. Journal of Managerial Psychology, 23(6), 670-687. http://dx.doi.org/10.1108/02683940810894747 
Liou, K. T., \& Nyhan, R. C. (1994). Dimensions of organizational commitment in the public sector: An empirical assessment. Public Administration Quarterly, 18(1), 99-118. http://www.jstor.org/stable/40861613

Lo, M. C., Ramayah, T., \& Min, H. W. (2009). Leadership styles and organizational commitment: A test on Malaysia manufacturing industry. African Journal of Marketing Management, 1(6), 133-139.

Lok, P., \& Crawford, J. (2004). The effect of organizational culture and leadership style on job satisfaction and organizational commitment: A cross-national comparison. Journal of Management Development, 23(4), 321-338. http://dx.doi.org/10.1108/02621710410529785

Maccoby, M. (2000). Understanding the difference between management and leadership. Research Technology Management, 43(1), 57-59.

Mandell, B., \& Pherwani, S. (2003). Relationship between emotional intelligence and transformational leadership style: A gender comparison. Journal of Business and Psychology, 17(3), 387-404. http://dx.doi.org/10.1023/A:1022816409059

Mayer, J. D. \& Salovey, P. (1997). What is emotional intelligence? In P. Salovey \& D. Sluyter (Eds.). Emotional development and emotional intelligence: Implications for educators (pp. 3-31). New York: Basic Books.

Meyer, J. P., \& Allen, N. J. (1991). A three-component conceptualization of organizational commitment. Human Resource Management Review, 1(1), 61-89. http://dx.doi.org/10.1016/1053-4822(91)90011-Z

Meyer, J. P., Allen, N. J., \& Smith, C. A. (1993). Commitment to organizations and occupations: Extension and test of a three-component conceptualization. Journal of Applied Psychology, 78(4), 538-551. http://dx.doi.org/10.1037/0021-9010.78.4.538

Meyer, J. P., Paunonen, S. V., Gellatly, I. R., Goffin, R. D., \& Jackson, D. N. (1989). Organizational commitment and job performance: It's the nature of the commitment that counts. Journal of Applied Psychology, 74(1), 152-156. http://dx.doi.org/10.1037/0021-9010.74.1.152

Mohamadkhani, K., \& Nasiri Lalardi, M. (2012). Emotional intelligence and organizational commitment between the hotel staff in Tehran, Iran. American Journal of Business and Management, 1(2), 54-59.

Morris, J. H., \& Steers, R. M. (1993). Structural Influences on Organizational Commitment. Journal of Vocational Behavior, 17(1), 50-57.

Mowday, R. T., Porter, L. W., \& Dubin, R. (1974). Unit performance, situational factors, and employee attitudes in spatially separated work units. Organizational Behavior and Human Performance, 12(2), 231-248. http://dx.doi.org/10.1016/0030-5073(74)90048-8

Mowday, R. T., Porter, L. W., \& Steers, R. M. (1982). Employee-organization linkage. The Psychology of Commitment Absenteism, and Turnover. London: Academic Press Inc.

Mowday, R. T., Steers, R. M., \& Porter, L. W. (1979). The measurement of organizational commitment. Journal of Vocational Behavior, 14(2), 224-247.

Nikolaou, I., \& Tsaousis, I. (2002). Emotional intelligence in the workplace: Exploring its effects on occupational stress and organizational commitment. The International Journal of Organizational Analysis, 10(4), 327-342. http://dx.doi.org/10.1108/eb028956

Northouse, P. G. (2015). Leadership: Theory and practice. Thousand Oaks, CA: Sage publications.

Parasuraman, S., \& Nachman, S. A. (1987). Correlates of Organizational and Professional Commitment The Case of Musicians in Symphony Orchestras. Group \& Organization Management, 12(3), 287-303. http://dx.doi.org/10.1177/105960118701200305

Pearce, C. L., \& Herbik, P. A. (2004). Citizenship behavior at the team level of analysis: The effects of team leadership, team commitment, perceived team support, and team size. The Journal of Social Psychology, 144(3), 293-310. http://dx.doi.org/10.3200/SOCP.144.3.293-310

Peeters, M. C. W., \& Meijer, S. (1995). Commitment in organizations, divisions and the job: A meaningful distinction. Gedrag en Organisatie, 8, 13-164.

Podsakoff, P. M., MacKenzie, S. B., \& Bommer, W. H. (1996). Transformational leader behaviors and substitutes for leadership as determinants of employee satisfaction, commitment, trust, and organizational citizenship behaviors. Journal of Management, 22(2), 259-298. http://dx.doi.org/10.1177/014920639602200204

Popper, M., Mayseless, O., \& Castelnovo, O. (2000). Transformational leadership and attachment. The Leadership Quarterly, 11(2), 267-289. http://dx.doi.org/10.1016/S1048-9843(00)00038-2 
Porter, L. W., Steers, R. M., Mowday, R. T., \& Boulian, P. V. (1974). Organizational commitment, job satisfaction, and turnover among psychiatric technicians. Journal of Applied Psychology, 59(5), 603-609. http://dx.doi.org/10.1037/h0037335

Prati, M. L., Douglas, C., Ferris, G. R., Ammeter, A. P., \& Buckley, M. R. (2003). Emotional intelligence, leadership effectiveness, and team outcomes. The International Journal of Organizational Analysis, 11(1), 21-40. http://dx.doi.org/10.1108/eb028961

Randall, D. M., \& O'driscoll, M. P. (1997). Affective versus calculative commitment: Human resource implications. The Journal of Social Psychology, 137(5), 606-617. http://dx.doi.org/10.1080/00224549709595482

Romzek, B. S. (1990). Employee investment and commitment: The ties that bind. Public Administration Review, 50(3), 374-382.

Salovey, P., \& Mayer, J. D. (1990). Emotional intelligence. Imagination, Cognition and Personality, 9(3), 185-211. http://dx.doi.org/10.2190/DUGG-P24E-52WK-6CDG

Scott-Ladd, B., Travaglione, A., \& Marshall, V. (2006). Causal inferences between participation in decision making, task attributes, work effort, rewards, job satisfaction and commitment. Leadership \& Organization Development Journal, 27(5), 399-414. http://dx.doi.org/10.1108/01437730610677990

Shamir, B., House, R. J., \& Arthur, M. B. (1993). The motivational effects of charismatic leadership: A self-concept based theory. Organization Science, 4(4), 577-594. http://dx.doi.org/10.1287/orsc.4.4.577

Shamir, B., Zakay, E., Breinin, E., \& Popper, M. (1998). Correlates of charismatic leader behavior in military units: Subordinates' attitudes, unit characteristics, and superiors' appraisals of leader performance. Academy of Management Journal, 41(4), 387-409. http://dx.doi.org/10.2307/257080

Stum, D. L. (1999). Workforce commitment: Strategies for the new work order. Strategy \& Leadership, 27(1), 4-7. http://dx.doi.org/10.1108/eb054623

Turner, J. R., \& Lloyd-Walker, B. (2008). Emotional intelligence (EI) capabilities training: Can it develop EI in project teams?. International Journal of Managing Projects in Business, 1(4), 512-534. http://dx.doi.org/10.1108/17538370810906237

Turner, J. R., \& Müller, R. (2005, June). The project manager's leadership style as a success factor on projects: A literature review. Project Management Institute.

Walumbwa, F. O., \& Lawler, J. J. (2003). Building effective organizations: transformational leadership, collectivist orientation, work-related attitudes and withdrawal behaviours in three emerging economies. International Journal of Human Resource Management, 14(7), 1083-1101. http://dx.doi.org/10.1080/0958519032000114219

Ward, E. A., \& Davis, E. (1995). The effect of benefit satisfaction on organizational commitment. Compensation and Benefits Management, 11, 35-35.

Weinberger, L. A. (2003). An examination of the relationship between emotional intelligence, leadership style and perceived leadership effectiveness. Dissertation Abstracts International, 64(11), 5828.

Wong, C. S., \& Law, K. S. (2002). The effects of leader and follower emotional intelligence on performance and attitude: An exploratory study. The Leadership Quarterly, 13(3), 243-274. http://dx.doi.org/10.1016/S1048-9843(02)00099-1

Yammarino, F. J., Spangler, W. D., \& Bass, B. M. (1993). Transformational leadership and performance: A longitudinal investigation. The Leadership Quarterly, 4(1), 81-102. http://dx.doi.org/10.1016/1048-9843(93)90005-E

Yukl, G. A. (1989). Leadership in organizations. India: Pearson Education.

Yukl, G. A. (1999). An evaluation of conceptual weaknesses in transformational and charismatic leadership theories. The Leadership Quarterly, 10(2), 285-305. http://dx.doi.org/10.1016/S1048-9843(99)00013-2

This work is licensed under a Creative Commons Attribution 3.0 License. 


\title{
Robustness of Price Perception: How Strong are Anchoring, Left-Digit- and Framing-Effects when Promoting Sales Offers?
}

\author{
Andreas Krämer \\ Correspondence: Andreas Krämer, BiTS-Business and Information Technology School GmbH, University of Applied \\ Sciences, Iserlohn, Germany and exeo Strategic Consulting AG, Bonn, Germany
}

Received: September 22, 2015 Accepted: October 10, 2015 Online Published: October 13, 2015

doi:10.11114/bms.v2i1.1137

URL: http://dx.doi.org/10.11114/bms.v2i1.1137

\begin{abstract}
While the large number of publications on behavioral pricing and partly spectacular results suggest that it is easily possible to influence parameters in the consumers' price perception (for example, by providing price anchors as competitive prices, 99-price endings, information on a relative or absolute saving or information on availability of the prices by the suppliers), this empirical study based on experimental designs comes to a contrary conclusion: it turns out that the assessment of perceived value for money and cheapness for different sales promotion campaigns in Germany (train ticket, smartphone flat rate, filter coffee) is amazingly robust and that psychological factors tested in different experiments have a relatively low impact. The theoretical, practical and research implications of these findings are discussed.
\end{abstract}

Keywords: behavioral pricing, framing, "left-digit-effect", odd ending pricing, anchoring and framing effects

\section{Introduction}

A decision to make a purchase can be influenced by many factors. One of the most powerful influences on purchase decisions is price. The classic price theory assumes that reducing the price of a product will lead to an increase in demand. A series of experiments with focus on behavioral economics could demonstrate in recent years that relationships between price and demand can be unexpected. One study took a look at comparable price points for items like women's clothing, using options such as $\$ 34$ vs. $\$ 39$, only to find that the higher $\$ 39$ price shockingly outsold the cheaper price point by $24 \%$. The same product sold more units with a price of $\$ 39$ then with a price of $\$ 34$ (Anderson \& Simester, 2003). The study results seem to support the proliferation of odd-ending prices (9-endings) in practice. Published studies report that from 30\% (Anderson \& Simester, 2003) up to $65 \%$ (Bray \& Harris, 2006; Simon, 2013) of retail prices end in 9 . The preponderance of 9-ending prices is not a new phenomenon and has been the subject of much comments and discussions over the past 70 years or even longer.

Other studies show that minor changes in price can have a strong impact on price perception. In other words, $\$ 3.99$ is perceived as much lower than $\$ 4.00$ but $\$ 3.69$ is not perceived as much lower than $\$ 3.70$. The reason for this: we look at numbers, we translate and map them onto a mental number line and essentially ignore the right-most digits (Schindler \& Kibarian, 1993).

However, odd ending prices are just one facet of psychological pricing. Other study results show that the presentation of the price, its length, color and font size can influence how consumers perceive the price. In his overview article Larson (2014) presented no less than 50 different tools for behavioral pricing.

\subsection{Particular Psychological Effects with Expected Strong Impact on Price Perception}

Subsequently, the focus should be on 3 areas of psychological pricing, which are particularly relevant in practice:

(1) Anchoring effect: When consumers receive objective information about a product, they tend to translate it into subjective values indicating whether this is expensive or inexpensive. This translation requires that they compare it to an internal standard that is based on prices of similar stimuli encountered in the past. This standard is typically referred to as a reference price and its effects are construed in terms of adaptation level theory (Helson 1964). As Janiszewski and Lichtenstein (1999) state, it is well accepted in the behavioral pricing literature that a consumer's perception of the attractiveness of a market price depends on a comparison of the market price to an internal reference price. At the same time an external reference price could be relevant for the consumer, for example where the price of a competitor's 
product is known.

(2) Price-ending-effect: If a price is $\$ 9.99$ whereas another is $\$ 10$, although the real difference is only one Cent, the fact that the number 10 has two digits, its perceived value is a lot higher than it really is. Therefore, the consumers think they are receiving great savings by going for the $\$ 9.99$. It is often described as the "left-digit-effect" (Thomas \& Morwitz, 2005), when the leftmost digit of the compared prices differ. However, there is evidence that the use of 99 in the right-most two digits of a retail price may create a low-price image in the minds of consumers (Schindler \& Kibarian 2001).

(3) Further pricing tactics often used as framing-effect like limited availability ("Scarcity effect") and notices of absolute and relative savings. Suggesting that quantities are limited due to market conditions (e.g. "only while supplies last") can influence product perception. If consumers are promotion-focused (either from product attributes or marketing messages), supply-based scarcity (e.g. purchase limits) can motivate more purchases (Ku, Kuo \& Kuo, 2012).

\subsection{Study Background and Objectives}

Advertising with a focus on price plays a relatively strong role in current media campaigns in Germany. For example, Deutsche Bahn (German railway) advertised an exclusive offer: "The best special fare (Sparpreis) there has ever been." (July 2015). This offer is tied to a specific train, has a limited availability and costs $€ 19$ for any ride within Germany. In order to emphasize the real availability (no scarcity) of this offer, actual sales figures were published on the railway's homepage. At the end of the campaign approximately 2.4 million tickets were sold.

At the same time $1 \& 1$, a leading telecommunication company, offered a new smart phone flat rate in the center of its advertising message: "The price is $€ 9.99$ per month for a 3 -fold flat rate (landline, mobile and internet)". The advertisement with the price took place as part of a nationwide print campaign.

For supermarkets, the strong focus on price is not new. Typically, for the so-called anchor products whose normal price level each consumer has in mind, it is common to reduce the prices temporarily. Especially coffee is an "action-driven business" (Fichtel, 2010). In a sales campaign in August 2015 the discounter Penny offered filter coffee "Dallmayer Prodomo" for $€ 3.99$ with a 38 Percent savings claim (the original price was stated as $€ 6.49$ ).

\subsection{Research Questions}

As these examples illustrate, there is no clear structure in what form and with what kind of framing prices are communicated. With regard to these actual price campaigns it is questionable what influence psychological factors have on the perception of prices from the perspective of consumers. Therefore, the following questions should be answered:

1. Does the price perception of sales promotions significantly change, when (a) consumers have competitor's price information available, (b) price variations are minor (1 Cent) or (c) additional framing elements (such as savings or limited availability) are used for price promotions?

2. Are the results concerning different framing techniques robust across different types of products?

3. How strong is the influence of framing techniques on price perception (mainly price cheapness and perceived value for money) compared with other factors like product involvement or price sensitivity?

4. Are the results of the experimental study consistent with the state of art wisdom concerning behavioral economics and behavioral pricing?

\section{Method}

\subsection{Procedures and Methodology}

In order to answer the research questions, an empirical study was developed and carried out, based on online interviews with $\mathrm{n}=547$ respondents (16+ years) in Germany. The recruitment was handled via online access panel. A screening part at the beginning made sure that the relevant age groups as well as an adequate regional coverage was given. The interviews were conducted in September 2015 and lasted an average of about 10 minutes. For an experimental design, the online study has several advantages. First, the questionnaire software enables to introduce graphical elements (advertisements) during the interview. Second, using a randomized selection process of respondents ensures that the different experimental groups are equally distributed in terms of relevant characteristics. ${ }^{1}$ Third, the relatively large sample size allows that the individual experimental groups are staffed by more than 100 cases and thus random fluctuation is significantly reduced.

1 For the data set was examined whether in fact no correlation between relevant parameters for assessing the price image and the classification of the subjects into different experimental groups has occurred. As part of a chi-square distribution test, the null hypothesis could not be refuted. 


\subsection{Experimental Design}

The experimental design includes three different experiments (train tickets, internet flat rate, filter coffee). In each product category a systematic variation was conducted by influencing factors. In the first group in addition to the original display the subjects received more information about the prices of the competitor (price advertising with lower absolute price point was shown first). To the second group only the original price advertising was presented. In group 3 and 4 the prices and details were changed to the original display (see Table 1).

Table 1. Experimental design

\begin{tabular}{|c|c|c|c|c|}
\hline $\begin{array}{l}\text { Product } \\
\text { category }\end{array}$ & $\begin{array}{l}\text { (1) Base sales offer }+ \\
\text { offer of competitor }\end{array}$ & (2) Base sales offer & $\begin{array}{l}\text { (3) Sales offer } \\
\text { variation } \# 1\end{array}$ & $\begin{array}{l}\text { (4) Sales offer } \\
\text { variation \#2 }\end{array}$ \\
\hline \multirow{4}{*}{$\begin{array}{l}\text { (A) Train } \\
\text { Ticket }\end{array}$} & Sales offer bus journey $€ 5$ & --- & --- & -- \\
\hline & one way & & & \multirow{3}{*}{ From $€ 19$} \\
\hline & From $€ 19$ & From $€ 19$ & From $€ 18.99$ & \\
\hline & 2.4 mill. tickets sold & 2.4 mill. tickets sold & 2.4 mill. tickets sold & \\
\hline \multirow{2}{*}{$\begin{array}{l}\text { (B) Smart } \\
\text { Phone flat } \\
\text { rate }\end{array}$} & $\begin{array}{r}\text { Sales offer } € 4.99 \\
\text { per month (Brand B) }\end{array}$ & --- & --- & --- \\
\hline & $\begin{array}{r}\text { Sales offer } € 9.99 \\
\text { per month } \\
\text { (before } € 14.99 \text { ) }\end{array}$ & $\begin{array}{r}\text { Sales offer } € 9.99 \\
\text { per month } \\
\text { (before } € 14.99 \text { ) }\end{array}$ & $\begin{array}{r}\text { Sales offer } € 10.00 \\
\text { per month } \\
\text { (before } € 14.99 \text { ) }\end{array}$ & $\begin{array}{r}\text { Sales offer } € 9.99 \\
\text { per month }\end{array}$ \\
\hline \multirow{4}{*}{$\begin{array}{l}\text { (C) Filter } \\
\text { coffee }\end{array}$} & Sales offer $€ 3.69$ & \multirow[t]{2}{*}{--} & \multirow[t]{2}{*}{---} & \multirow[t]{2}{*}{---} \\
\hline & Brand C & & & \\
\hline & Sales offer $€ 3.99$ & Sales offer $€ 3.99$ & Sales offer $€ 4.00$ & Sales offer $€ 3.99$ \\
\hline & $\begin{array}{r}\text { Brand A (before } \\
€ 6.49,-38 \%)\end{array}$ & $\begin{array}{r}\text { Brand A (before } \\
€ 6.49,-38 \%)\end{array}$ & $\begin{array}{r}\text { Brand A (before } \\
€ 6.49,-38 \%)\end{array}$ & $\begin{array}{r}\text { Brand A (max. } 3 \text { items } \\
\text { per purchase) }\end{array}$ \\
\hline
\end{tabular}

The graphics used in the interview were campaigns of competing companies in the market. As train journeys currently compete with long-distance busses, a promotional campaign of the best-known provider was selected as a competitor information (Krämer \& Jung, 2014). The additional advertisements for the smartphone tariff and filter coffee are real advertisements (with very low prices) of a main competitor. In order to cover all relevant price image dimensions 7 image statements (for detailed description see Table 3) had to be evaluated (scale from $1=$ strongly agree to $6=$ strongly disagree) after the advertisements were shown.

\subsection{Data Analysis}

To examine the significance within the three sample groups and to statistically evaluate background characteristics, the repeated measures ANOVA for overall comparisons, as well Chi-Square tests were used. In order to examine differences of mean values across experimental groups a pairwise t-test for independent samples was conducted. To analyze the data SPSS version 22 was used.

\section{Results}

\subsection{Buying Decision of Consumers: Focus on Price or Brand}

Before the individual experiments were carried out, there was a brief sequence of questions covering the typical buying habits of respondents. The interviewees should indicate for different product categories whether their purchase decisions are based on price or rather on the brand/seller. As expected, these results differ across product categories ${ }^{2}$. Since it has been suggested in recent studies that price sensitivity of consumers has a strong influence on the price perception (Anderson \& Simester, 2003), it should be examined in this section, whether the sample contains typical distribution with respect to the price or brand orientation. As reference data, the study "Best for Planning" was used"; it contains representative data on shopping behavior for Germany.

While the price of beer plays a subordinate role in the purchase decision and the orientation is strongly focused on the brand, the situation is the other way around when deciding on smartphone tariffs. Here the price plays a predominant role (51\% of interviewees indicate that they mainly focus on the price). Concerning filter coffee, the distribution between price and brand-oriented consumers is rather balanced. About a quarter of respondents see the price as a decisive factor within the purchase decision, another quarter of respondents is focused on brand.

2 The aim of this procedure was to generally test, whether respondents are more price or brand sensitive in terms of general purchase behavior. Therefore, product categories such as beer or coffee machines were also shown, although they have no specific relevance for the experimental design appearing later during the interview.

3 Best for planning (b4p) is a market-media study of several German publishing houses (Axel Springer, Bauer Media Group, Gruner + Jahr and Hubert Burda Media). Overall, 30,000 interviews are conducted per year. The results are publicly available. 
Table 2. Relevance of price and brand within the purchase decision (\% of respondents)

\begin{tabular}{lcccc}
\hline $\begin{array}{l}\text { Product } \\
\text { category* }\end{array}$ & $\begin{array}{c}\text { Price } \\
\text { focus** }\end{array}$ & $\begin{array}{c}\text { Price \& } \\
\text { brand }\end{array}$ & $\begin{array}{l}\text { Brand } \\
\text { focus }\end{array}$ & $\begin{array}{c}\text { Do not buy / Do not } \\
\text { know }\end{array}$ \\
\hline Beer & $11 \%(11 \%)$ & $25 \%(25 \%)$ & $42 \%(32 \%)$ & $22 \%(33 \%)$ \\
Filter coffee & $24 \%(18 \%)$ & $32 \%(36 \%)$ & $24 \%(34 \%)$ & $20 \%(12 \%)$ \\
Coffee machine & $28 \%(28 \%)$ & $40 \%(42 \%)$ & $19 \%(18 \%)$ & $13 \%(13 \%)$ \\
Flat rate (cellphone) & $51 \%(--\%)$ & $26 \%(---\%)$ & $13 \%(--\%)$ & $33 \%(--\%)$ \\
\hline
\end{tabular}

* Question: When you think of the following products, do you pay attention rather to brand or to price? Categories: (1) mainly price, (2) rather price, (3) both price and brand, (4) rather brand, (5) mainly brand, (6) I do not buy this product, (7) No answer.

** Results of own study (reference study b4p 2014).

\subsection{Experiment (A) with Train Tickets}

As shown in Table 3, the evaluation of price image statements is robust across experimental groups. While significant differences occur in terms of evaluating the ad as decoy or as raising clear expectations, important image sub dimensions such as cheapness ("is cheap") or price-performance-ratio ("is good value for money") do not significantly differ. Whether there is additional information on prices of competitors (potential anchor-effect), or whether the price is "From $€ 18.99$ " instead of "From $€ 19$ " or whether there is additional information on tickets already sold (potential additional framing), there is no measureable effect concerning mean values. ${ }^{4}$ Overall, the sub dimension transparency and clarity of expectation are assessed particularly critical.

Table 3. Price image evaluation sales offer train tickets

\begin{tabular}{|c|c|c|c|c|}
\hline Sales offer* & $\begin{array}{c}\text { (1) Base sales offer }+ \\
\text { offer of competitor } \\
n=140\end{array}$ & $\begin{array}{c}\text { (2) Base sales } \\
\text { offer } \\
n=137 \\
\end{array}$ & $\begin{array}{l}\text { (3) Sales offer } \\
\text { variation \#1 } \\
n=143 \\
\end{array}$ & $\begin{array}{l}\text { (4) Sales offer } \\
\text { variation \#2 } \\
n=127 \\
\end{array}$ \\
\hline$\ldots$ is cheap & $2.7(-0.1) \mathrm{p}=0.75$ & $2.8(--)$ & $3.0(0.2) \mathrm{p}=0.28$ & $2.8(-0.1) \mathrm{p}=0.24$ \\
\hline$\ldots$ is transparent & $3.8(-0.2) \mathrm{p}=0.31$ & $4,0(--)$ & $4.0(0.0) p=0.97$ & $3.8(-0.1) p=0.28$ \\
\hline ... good value for money & $3.0(-0.2) p=0.27$ & $3.2(--)$ & $3.2(0.0) \mathrm{p}=0.95$ & $3.1(0.1) \mathrm{p}=0.59$ \\
\hline$\ldots$ is fair & $3.0(-0.1) p=0.64$ & $3.1(--)$ & $3.3(0.2) \mathrm{p}=0.32$ & $3.3(0.4) \mathrm{p}=0.22$ \\
\hline ... clear expectation & $3.5(-0.3) p=0.07$ & $3.8(--)$ & $3.9(0.1) \mathrm{p}=0.50$ & $3.7(0.0) \mathrm{p}=0.55$ \\
\hline$\ldots$ is a decoy & $2.5(0.5) p=0.08$ & $2.0(--)$ & $2.3(0.3) p=0.09$ & $2.4(0.5) p=0.02$ \\
\hline Supplier is & $3.4(0.3) \mathrm{p}=0.11$ & $3.1(--)$ & $3.4(0.3) \mathrm{p}=0.15$ & $3.1(0.2) \mathrm{p}=0.72$ \\
\hline
\end{tabular}

inexpensive

* Question: Please rate the following statements to this ad: Please use a scale from $1=$ I completely agree to $6=\mathrm{I}$ completely disagree. Values presented in order of occurrence: Mean (absolute deviation from base sales offer), significance.

While no significant results are revealed between the experimental groups at the price-image factors such as cheapness and price-performance-ratio, this is the case with the factors age and product usage, respectively. Here clear dependencies arise with a high significance (for both attributes $\mathrm{p}<0.00$ ). These results are consistent with other empirical findings (Krämer, 2015a) that also confirm that in particular non-users and younger consumers assess the German railway relatively critically (see Table 4 ).

Table 4. Perceived cheapness of promoted train ticket prices depending on rail usage and age

\begin{tabular}{lccc}
\hline \multirow{2}{*}{ Perceived cheapness* } & Heavy-Users & Low-/Medium-Users & Non-Users \\
& Rail & Rail & $36.5 \%$ \\
\hline Top-2 (agreement) & $59.9 \%$ & $50.2 \%$ & $41.1 \%$ \\
Indifferent & $39.3 \%$ & $39.8 \%$ & $22.4 \%$ \\
Low-2 (disagreement) & $6.8 \%$ & $10.0 \%$ & Age: $60+$ years \\
\hline Perceived cheapness & Age: $<30$ years & Age: $30-59$ years & $49.2 \%$ \\
\hline Top-2 (agreement) & $36.5 \%$ & $45.5 \%$ & $34.1 \%$ \\
Indifferent & $57.7 \%$ & $41.0 \%$ & $16.7 \%$ \\
Low-2 (disagreement) & $5.8 \%$ & $13.5 \%$ & \\
\hline
\end{tabular}

* Question: Please rate the following statements to this ad: Please use a scale from $1=$ I completely agree to $6=\mathrm{I}$ completely disagree.

\subsection{Experiment (B) with Smart Phone Flat Rate}

As shown in Table 5, the evaluation of price image statements is even more robust across experimental groups concerning price ads for smartphone flat rates. Again, results for image sub dimensions such as cheapness ("is cheap") or price-performance-ratio ("is good value for money") do not significantly differ. Whether there is additional information on prices of competitors (potential anchor-effect), which is almost 50\% lower, or whether the price is $€ 10.00$ instead of $€ 9.99$ (potential "left-digit-effect") or whether there is additional information on savings compared

4 It should be noted that German rail typically communicated anchor prices like "From €29" indicating the lowest possible price point for consumers without discount card. Effective prices paid by travellers may vary according to their booking profile. 
with usual sales prices (potential additional framing), there is no measureable effect concerning mean values. Overall, the level of assessment is lower (less critical) compared with experiment A (train tickets).

Table 5. Price image evaluation sales offer smart phone flat rate

\begin{tabular}{|c|c|c|c|c|}
\hline Sales offer* & $\begin{array}{c}\text { (1) Base sales offer }+ \\
\text { offer of competitor } \\
n=150\end{array}$ & $\begin{array}{c}\text { (2) Base sales } \\
\text { offer } \\
n=137\end{array}$ & $\begin{array}{l}\text { (3) Sales offer } \\
\text { variation } \# 1 \\
n=125 \\
\end{array}$ & $\begin{array}{l}\text { (4) Sales offer } \\
\text { variation \#2 } \\
n=135 \\
\end{array}$ \\
\hline$\ldots$ is cheap & $2.5(0.1) \mathrm{p}=0.65$ & $2.4(--)$ & $2.2(-0.2) \mathrm{p}=0.72$ & $2.4(0.0) \mathrm{p}=0.87$ \\
\hline$\ldots$ is transparent & $3.0(-0.2) \mathrm{p}=0.23$ & $3.2(--)$ & $3.2(0.0) \mathrm{p}=0.78$ & $3.2(0.0) \mathrm{p}=0.69$ \\
\hline ... good value for money & $2.6(0.0) \mathrm{p}=0.61$ & $2.6(--)$ & $2.5(-0.1) p=0.50$ & $2.6(0.0) \mathrm{p}=0.98$ \\
\hline$\ldots$ is fair & $2.7(-0.1) \mathrm{p}=0.50$ & $2.8(--)$ & $2.8(0.0) \mathrm{p}=0.87$ & $2.7(-0.1) p=0.78$ \\
\hline ... clear expectation & $3.1(0.1) \mathrm{p}=0.78$ & $3.2(--)$ & $3.1(-0.1) \mathrm{p}=0.73$ & $3.1(-0.1) p=0.54$ \\
\hline$\ldots$ is a decoy & $2.7(0.3) \mathrm{p}=0.10$ & $2.4(--)$ & $2.3(-0.1) \mathrm{p}=0.47$ & $2.6(0.2) \mathrm{p}=0.26$ \\
\hline $\begin{array}{l}\text { Supplier is } \\
\text { inexpensive }\end{array}$ & $2.4(0.0) \mathrm{p}=0.58$ & $2.4(--)$ & $2.4(0.0) \mathrm{p}=0.63$ & $2.5(0.1) \mathrm{p}=0.29$ \\
\hline
\end{tabular}

* Question: Please rate the following statements to this ad: Please use a scale from $1=$ I completely agree to $6=\mathrm{I}$ completely disagree. Values presented in order of occurrence: Mean (absolute deviation from base sales offer), significance.

In addition to measuring the impact of experimental factors on the price perception, further dependencies were analyzed. Respondents who described themselves as rather brand-oriented showed a particularly positive evaluation (Chi-Square: $\mathrm{p}<0.00$ ). Top-2 evaluations concerning cheapness reach $74 \%$, while the corresponding share in the group of price-oriented consumers amounts to $54 \%$ (Table 6). A similar dependency can be found for the perceived value for money, although with a lower level of agreement ${ }^{5}$.

Table 6. Perceived cheapness of promoted smartphone flat rate depending consumer focus

\begin{tabular}{lccc}
\hline Perceived cheapness & $\begin{array}{c}\text { Price focus } \\
(\mathrm{n}=232)\end{array}$ & $\begin{array}{c}\text { Price \& brand } \\
(\mathrm{n}=171)\end{array}$ & $\begin{array}{c}\text { Brand focus } \\
(\mathrm{n}=82)\end{array}$ \\
\hline Top-2 (agreement) & $53.9 \%$ & $63.2 \%$ & $74.4 \%$ \\
Indifferent & $38.4 \%$ & $30.4 \%$ & $19.5 \%$ \\
Low-2 (disagreement) & $7.7 \%$ & $6.4 \%$ & $6.1 \%$ \\
\hline & Question: Please rate the following statements to this ad: Please use a scale from 1= I completely agree to 6= I completely disagree.
\end{tabular}

One explanation for the particularly positive assessment of cheapness in the group of brand-oriented consumers could be that the surprise-effect of the aggressive price promotion is particularly strong here. Since the seller is a reseller of network capacity, the displayed price level of about $10 €$ per month for the smartphone flat price offer is at least $50 \%$ below the typical prices offered by branded German network companies (Telekom, Vodafone, O2). It should be noted that $1 \& 1$ 's special offer was embedded in an overarching brand campaign.

\subsection{Experiment (C) with Filter Coffee}

Unlike the previous two experiments, the third experiment (price advertising for filter coffee) at least partially shows expected results. While presenting a competitor's ad (promotional ad of another discount market with a price of $€ 3.69$ per 500 grams filter coffee) has no significant effect on the assessment of perceived cheapness and value for money of the base product, there are clear differences when the filter coffee (original "base" offer) is offered for slightly higher price of $€ 4.00$ instead of $€ 3.99$. Clearly, small changes in price lead to a significantly worse assessment of price cheapness and value for money (see Table 7). Therefore, at least one experimental design shows results, which are consistent with the "left-digit-effect", frequently promoted in the academic literature. The differences can be explained by the theory of price threshold (Simon, 2013). When consumers get used to prices as $€ 3.99$, this can lead to strong reactions when exceeding this threshold.

Also a framing of the offer by limiting the purchasable quantity per buyer does not lead to changes in price image values compared to the base offer. One could expect that a limited availability would communicate a shortage of the product and thus a higher value from the customer's perspective.

A strong dependency between age of the interviewees and the assessment of the perceived cheapness is measured. Approval (\% top-2) is highest in the age group of seniors with $67 \%$, lowest in the age group of respondents younger than 30 years. This might be explained by a lower involvement of younger consumers towards filter coffee (affinity for coffee capsules, etc.).

\footnotetext{
5 For all 3 Product categories it can be stated that there is a strong $(r>0.5)$ and significant $(p<0.00)$ correlation between the first five statements.
} This does not apply to the last two statements. 
Table 7. Price image evaluation sales offer filter coffee

\begin{tabular}{|c|c|c|c|c|}
\hline Sales offer* & $\begin{array}{l}\text { (1) Base sales offer }+ \\
\text { offer of competitor } \\
n=147\end{array}$ & $\begin{array}{c}\text { (2) Base sales } \\
\text { offer } \\
n=135\end{array}$ & $\begin{array}{l}\text { (3) Sales offer } \\
\text { variation \#1 } \\
n=133\end{array}$ & $\begin{array}{l}\text { (4) Sales offer } \\
\text { variation } \# 2 \\
n=132\end{array}$ \\
\hline$\ldots$ is cheap & $2.3(0.0) \mathrm{p}=0.72$ & $2.3(--)$ & $2.7(-0.4) p=0.01$ & $2.5(0.2) \mathrm{p}=0.14$ \\
\hline$\ldots$ is transparent & $2.4(0.2) \mathrm{p}=0.22$ & $2.2(--)$ & $2.2(0.0) \mathrm{p}=0.83$ & $2.3(0.1) \mathrm{p}=0.49$ \\
\hline$\ldots$ good value for money & $2.3(0.1) \mathrm{p}=0.75$ & $2.2(--)$ & $2.5(0.3) p=0.07$ & $2.3(0.1) \mathrm{p}=0.52$ \\
\hline$\ldots$ is fair & $2.4(0.0) \mathrm{p}=0.97$ & $2.4(--)$ & $2.5(0.1) \mathrm{p}=0.58$ & $2.5(0.1) p=0.65$ \\
\hline ... clear expectation & $2.1(0.0) \mathrm{p}=0.88$ & $2.1(--)$ & $2.0(-0.1) \mathrm{p}=0.27$ & $2.0(-0.1) \mathrm{p}=0.25$ \\
\hline$\ldots$ is a decoy & $3.2(0.0) \mathrm{p}=0.85$ & $3.2(--)$ & $3.7(0.5) p=0.03$ & $3.3(0.1) p=0.70$ \\
\hline $\begin{array}{l}\text { Supplier is } \\
\text { inexpensive }\end{array}$ & $3.2(-0.5) p=0.07$ & $3.7(--)$ & $3.7(0.0) \mathrm{p}=0.88$ & $3.4(-0.3) \mathrm{p}=0.19$ \\
\hline
\end{tabular}

* Question: Please rate the following statements to this ad: Please use a scale from $1=\mathrm{I}$ completely agree to $6=\mathrm{I}$ completely disagree. Values presented in order of occurrence: Mean (absolute deviation from base sales offer), significance.

\subsection{Overall Results and Conclusions}

Against the background of the discussion about behavioral pricing, often dominated by the impression, influencing consumers' price perception is possible through seemingly minor changes in the presentation of prices the results of the present experimental study are very robust.

Only for the product category filter coffee significant influences on important price image dimensions like perceived cheapness and value for money are detected. In the experiments with train tickets or smartphone flat rates no significant influences due to experimental factors like competitive prices, anchor prices, "left-digit-effects" or availability constraints can be identified.

The "left-digit-effect" was displayed by changes between groups 2 and 3 (€9.99 vs. $€ 10.00$ for smartphone flat rate and $€ 3.99$ vs. $€ 4.00$ for filter coffee) and can only be confirmed in one experiment. This suggests that it is not a fundamental effect, but depends on the product. As Choi, J. et al. (2014) stated, "people are more likely to choose hedonic over utilitarian products when they have odd-ending prices". This gives a hint that conventional understanding of psychological pricing has to be adjusted. Since there is no evidence of a clear structure to optimize price signaling, a more pragmatic approach to pricing is recommended.

Overall, the degree of price image level increases from experiment A to C. Consumers' evaluation of railway special fares is positive, but more critical compared with smart phone tariffs and filter coffee sales promotions as presented in this study. However, it has to be considered that the product complexity and need for explanation of the products is different: highest for the train tickets and lowest for the filter coffee.

As illustrated, unique drivers for the price perception can be determined, which act stronger than the psychological factors that varied across experimental groups: age, product affinity and price sensitivity of consumers. The effects of these drivers, however, have a strong variance by product category.

\section{Discussion}

An irritating result arises from the train tickets experiment between the versions from $€ 19$ (group 2) and from $€ 18.99$ (group 3). Not only that the lower price has no positive impact on the perceived cheapness, as it might be expected, the price reduction even leads to a significant deterioration in the perception of the price (see Figure 1). While the agreement on cheapness for the price of $€ 19$ was $48 \%$, the corresponding figure drops to $37 \%$ at the comparatively lower price of $€ 18.99$. Here, possibly the transcription of the pricing information works differently. Hence, one could assume that it is easier for the consumers to transcript $€ 19$ as inexpensive compared to the price of $€ 18.99$ (for rail prices in Germany price endings with 99 are rather uncommon). The weak evaluation of the $€ 18.99$ priced train ticket compared to the base offer of $€ 19$ might also be explained due to a different quality perception (Balan, 2013).

Coulter, Choi, \& Monroe (2012) demonstrate that including commas (e.g. \$1.599 vs. \$1599) and cents (e.g., $\$ 1599.85$ vs. \$1599) in Arabic written form (i.e. how it is perceived visually) can change how the price is encoded and represented verbally in a consumer's memory. Other studies suggest consumers appear to favor round numbers when paying for goods and services (Lynn, Flynn \& Helion, 2013) and adopting round-pound prices may be more effective (Bray \& Harris, 2006).

Finally, the relationship between the perceived cheapness of the investigated product and the general inexpensiveness of the provider should be emphasized. For both product categories, train tickets as well as filter coffee, clear differences between the two parameters are determined. The favorability of the product is assessed significantly more positively than the inexpensiveness of the provider. This is reasonable in case of train tickets, as 
in Germany the price image of the national rail carrier is relatively poor. Concerning coffee this result is sobering, since coffee is regarded as anchor product and it is expected that consumers transfer their product price evaluation over to the general product portfolio of the supermarket. In contrast, in case of the smartphone flat rate both parameters are relatively close: the sales offer is perceived inexpensive, so is the seller. This is probably explained by the fact that the supplier has a relatively limited portfolio of products.

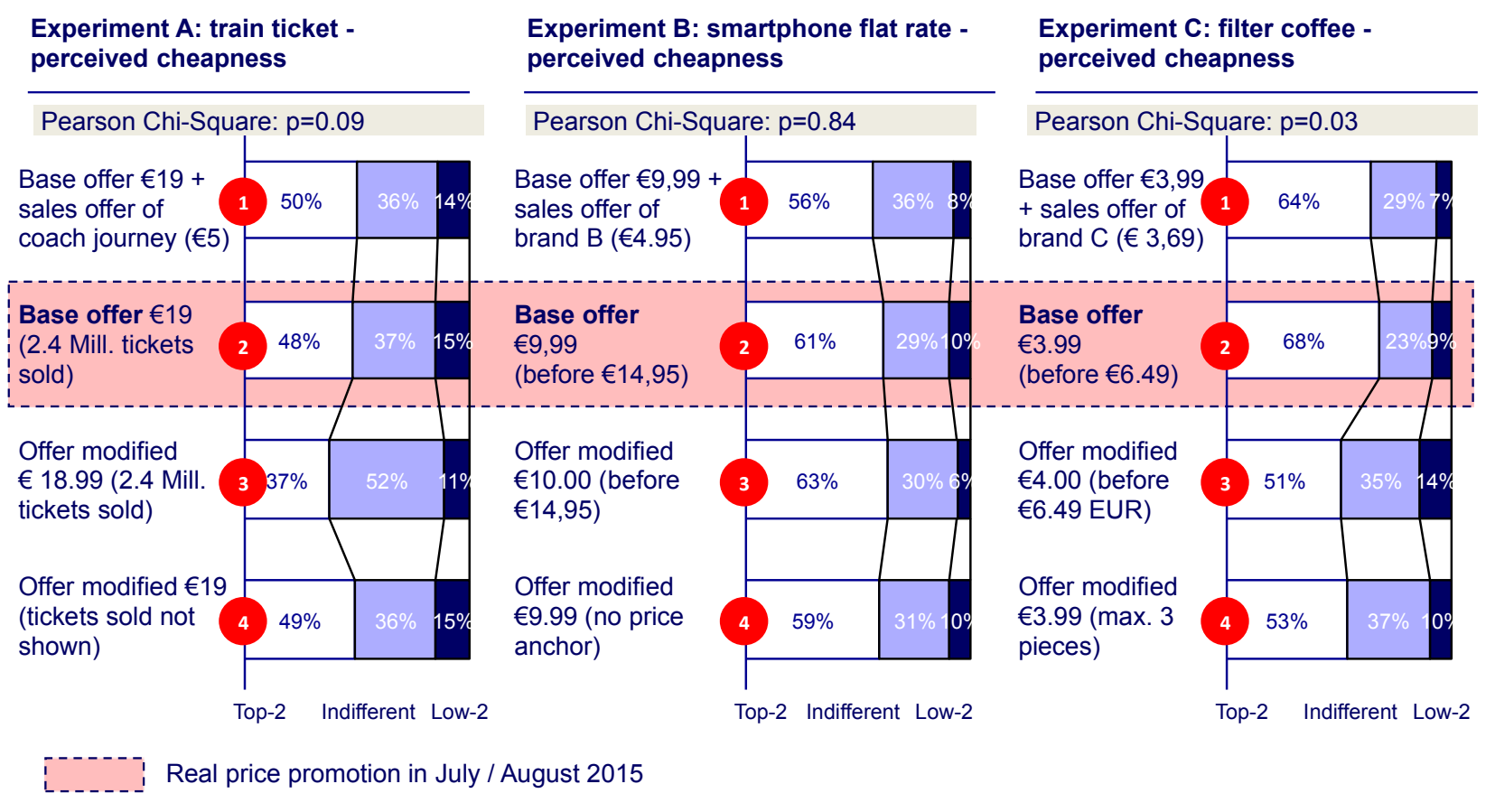

Figure 1. Consumers' perceived cheapness (3 categories, 4 experimental groups)

The present study confirms what well-known pricing researchers have already expressed: the effect price changes have on purchase behavior are still unknown (Adaval, 2013) or strongly influenced by contextual factors (Cheng \& Monroe, 2013). The large number of publications does not result in a uniform theory of behavioral pricing.

\section{Outlook and Final Remarks}

While the proliferation of studies ${ }^{6}$ on behavioral pricing and thereby partly spectacular results suggest that it is easily possible to influence parameters in the consumers' price perceptions, there are also critics to behavioral pricing: One criticism is directed at the sometimes contradictory results of often cited "theories" (such as the endowment effect). This shows that the implementation of conducted experiments has a strong influence on the study results, so that the reliability in total is low (Plott \& Zeiler, 2005). The high elasticity of interpretation of results leads to another problem that Beck (2015) describes as follows: "What is the benefit of a theory which predicts no clear results?"

When Choi, J. et al. (2014) stated, that "... there is evidence, that there is no clear structure to optimize price signaling" one might ask for recommendations on a more pragmatic approach to pricing. Considering the following guideline might help (Krämer, 2015b):

(1) Continuous segmentation: the increasing speed of market changes requires a modified segmentation of the market in two directions: First, apply continuous customer segmentation instead of an ad-hoc approach. Second, avoid multiple, concurrent and potentially contradictory segmentations (Williams, 2014). To ensure that the segmentation can be efficiently used for pricing decisions, the segmentation should also be based on the price sensitivity and willingness to pay of customers (Krämer \& Burgartz, 2015).

(2) No blind faith for results of market simulation models: elaborate survey methods such as conjoint measurement not only provide utility values for different features and their attributes. Moreover, these can be used as input data for simulation models. However, the quality of the results strongly depends on the inputs and the survey design (used attributes and levels). Therefore, market simulation models can be helpful, as long as the users are aware of the limitations (they will not fully reflect the price psychological effects).

6 Simon (2013) notes that since the award of the Nobel Prize to Kahneman and Tversky for their work on Prospect Theory "the number of authors and publications dedicated to behavioral economic problems explosively swells." 
(3) Testing under real market conditions: if possible, hypotheses should first be developed regarding the expected price elasticity and price-demand relationship and then reviewed in a subsequent targeted market testing under real purchasing conditions. As Thomke \& Manzi (2014) described in a business case: "when... executives investigated a new pricing for a product sold by weight, the results were unequivocal. By far, the best price was for a quarter pound of the product, and that price was for an amount that ended in $\$ .25$. That result went sharply against the grain of conventional wisdom, which typically calls for prices ending in 9 , such as $\$ 4.99$ or $\$ 2.49$."

\section{Acknowledgements}

The author is grateful to Rogator AG, Nuremberg, for the provision of survey software, the programming of the questionnaire and the complete data management including access to the online panel. Many thanks also Dr. Gerd Wilger and Dr. Robert Bongaerts (exeo) as well as Martin Jung for valuable suggestions and substantive input to the study.

\section{References}

Adaval, R. (2013). The utility of an information processing approach for behavioral price research. AMS Rev, 3, 120-134. http://dx.doi.org/10.1007/s13162-013-0045-x

Anderson, E. T., \& Simester, D. I. (2003). Effects of $\$ 9$ Price Endings on Retail Sales: Evidence from Field Experiments, Quantitative Marketing and Economics, 1, 93-110. http://dx.doi.org/10.1023/A:1023581927405

B4P: best for planning Data set 2014. Retrived from https://online.mds6.de/mdso6/b4p.php

Balan, C. (2013). Research on Odd Prices. In: Hinterhuber, A., Liozu, S. (eds.), Innovation in Pricing. Abingdon, 376-392.

Beck, H. (2015). Zeit für die Euphoriebremse: Zur Theorie, Empirie, Ethik und Politik der Behavioral Economics. http://www.marktforschung.de/hintergruende/themendossiers/behavioral-economics/dossier/?tx_news_pi1[news]= 425738\&cHash $=5 \mathrm{~d} 341 \mathrm{de} 6 \mathrm{bcaf} 6481292 \mathrm{~d} 504 \mathrm{c} 37 \mathrm{a} 234 \mathrm{a} 1$

Bray, J. P., \& Harris, C. (2006). The Effect of 9-Ending Prices on Retail Sales: A Quantitative UK Based Field Study. Journal of Marketing Management, 22(5-6), 601-617, http://dx.doi.org/10.1362/026725706777978631

Choi, J. et al. (2014). The odd-ending price justification effect: The influence of price-endings on hedonic and utilitarian consumption. Journal of the Academy of Marketing Science, 42(5), 1-13, September. http://dx.doi.org/ $10.1007 / \mathrm{s} 11747-014-0369-6$

Coulter, K. S., Choi, P., \& Monroe, K. B. (2012). Comma N' cents in pricing: The effects of auditory representation encoding on price magnitude perceptions. Journal of Consumer Psychology, 22(3), 395-407. Http://dx.doi.org/10.1016/j.jcps.2011.11.005

Fichtel, K. (2010). Billiger Kaffee als Lockangebot beim Discounter. http://www.abendblatt.de/wirtschaft/article108530206/Billiger-Kaffee-als-Lockangebot-beim-Discounter.html

Gaston, B. C. (2011). Consumer Preferences for 99-ending prices: The mediating role of price consciousness”, Working Paper, Universidad Carlos III de Madrid, http://portal.uc3m.es/portal/page/portal/dpto_economia_empresa/home/research/Research\%20documents/working _papers/ewp2011/1105.pdf

Helson, H. (1964). Adaptation-level theory. New York: Harper \& Row.

Janiszewski, C., \& Lichtenstein, D. R. (1999). A Range Theory Account of Price Perception. Journal of Consumer Research, 25 (4), 353-368. http://dx.doi.org/10.1086/209544

Krämer, A. (2015a). Rabatt- und Kundenbindungskarten im Personenverkehr - Länderübergreifende Analyse zu den Bahn-Rabattkarten in der DACH-Region, ZEVrail, 139(9), 341-347.

Krämer, A. (2015b). Pricing in a VUCA World - How to Optimize Prices, if the Economic, Social and Legal Framework Changes Rapidly. In: Mack et al. (eds.), Managing in a VUCA World. Springer, New York, 115-128. http://dx.doi.org/10.1007/978-3-319-16889-0

Krämer, A., \& Burgartz, T. (2015). Customer Value Controlling - Combining Different Value Perspectives. Business and Management Studies, 1(2), 11-19, http://dx.doi.org/10.11114/bms.v1i2.814

Krämer, A., \& Jung, M. (2014). Zwischen Preiswettbewerb und Preiskampf-Das Spannungsfeld zwischen Nachfrageboom und Preiserosion bei Reisen mit Fernlinienbussen. Internationales Verkehrswesen, 66(4), 58-60.

Ku, H., Kuo, C., \& Kuo, T. (2012). The Effect of Scarcity on the Purchase Intentions of Prevention and Promotion Motivated Consumers. Psychology and Marketing, 29(8), 541-548. http://dx.doi.org/10.1002/mar.20541 
Larson, R. B. (2014). Psychological Pricing Principles for Organizations with Market Power. Journal of Applied Business and Economics, 16(1), 11-25.

Lynn, M., Flynn S. M., \& Helion, C. (2013). Do consumers prefer round prices? Evidence from pay-what-you-want decisions and self-pumped gasoline purchases. Journal of Economic Psychology, 36(June), 96-102, http://dx.doi.org/10.1016/j.joep.2013.01.010

Plott, C. R., \& Zeiler, K. (2005). The Willingness to Pay-Willingness to Accept Gap, the "Endowment Effect" Subject Misconceptions, and Experimental Procedures for Eliciting Valuations. The American Economic Review, 95(3) 530-545. http://dx.doi.org/10.1257/0002828054201387

Schindler, R. M., \& Kibarian, T. M. (2001). Image Communicated by the Use of 99 Endings in Advertised Prices. Journal of Advertising, 30(Winter), 95-99. http://dx.doi.org/10.1080/00913367.2001.10673654

Simon, H. (2013). Preisheiten - Alles, was Sie über Preise wissen müssen. Campus, Frankfurt.

Thomas, M., \& Morwitz, V. (2005). Penny Wise and Pound Foolish: The Left-Digit Effect in Price Cognition, Journal of Consumer Research 32(1), 54-64. http://dx.doi.org/10.1086/429600

Thomke, S., \& Manzi, J. (2014). The Discipline of Business Experimentation, HBR. December 2014, 71-79.

Williams, D. S. (2014): Connected CRM - Implementing a Data-Driven, Customer-Centric Business Strategy, Wiley, Hoboken.

\section{$(\mathrm{cc})$ EY}

This work is licensed under a Creative Commons Attribution 3.0 License. 


\title{
Mindfulness and Leadership: A Critical Reflection
}

\author{
Servaas van Beekum, drs \\ Correspondence: Servaas van Beekum, 158 Wellington Street, Bondi Beach 2026, NSW, Australia. Tel: +61400460429
}

\author{
Received: October 29, 2015 Accepted: November 2, 2015 Online Published: November 5, 2015 \\ doi:10.11114/bms.v2i1.1190 URL: http://dx.doi.org/10.11114/bms.v2i1.1190
}

\begin{abstract}
This paper critically highlights the history and the current use of the concept of mindfulness, from its Buddhist roots via medical application and organizational consulting into its application as a management tool. The paper puts the concept of mindfulness in its historical context, mentions some of the controversies the 'brand of mindfulness' has stirred and prefers the term 'being mindful' over 'mindfulness'. However, as Stolarov (1992) argued: the mind in isolation is a myth. The mind itself is social and relational in such a way that the intrapsychic inner world is directly related to the relational context in which it is embedded. In consulting and management, being mindful is, beyond an individual process of growth and development, also relational, recognizing that there are two or more entities working in a mutual and reciprocal process.

Once we apply 'being mindful' on professionals in organizations it is clear that this can improve the wellbeing of leaders, managers and staff and the overall effectiveness of an organization. In the organizational literature the concept of 'deep thinking' is explored in marketing and sales. The paper promotes, explores and elaborates the concept of being mindful, including deep thinking, as essential for practical and spiritual aspects of organizational and corporate life, in particular for the transformational tasks of leaders and managers. Eight characteristics of mindful leadership are elaborated.
\end{abstract}

Finally the potential parallel process of the rise of mindfulness and transactional analysis, stands out as a warning.

Keywords: mindfulness, mindful consulting, relational, deep thinking, transformation, leadership

\section{Mindfulness}

Mindfulness, as meant in the original Sanskrit word 'sati', is an essential part of Buddhist practice and promotes an attentive awareness of the reality of things in the here and now. Mindfulness is one of many translations of the word sati. Others include: awareness, inspection, recollection or retention. Mindfulness is pre-symbolic as Gunaratana explains in his famous 'Mindfulness in plain English': "Mindfulness can be experienced and it can be described, but keep in mind that the words are only fingers pointing at the moon. They are not the thing itself" (Gunaratana, 2011, p.131). Mindfulness is the center of and key to the process of Vipassana meditation. It is both the goal of this meditation and the means to that end. One can reach mindfulness by being ever more mindful.

In every day life, mindfulness stands for "the active, watchful mind" (Rhys Davids, 1881, p.107), which means not only, "moment to moment awareness of present events," but also, "remembering to be aware of something or to do something at a designated time in the future" (Mind \& Life Institute, 2014).

In medicine, in particular in psychiatry, mindfulness practice is used as an antidote to delusion, supposedly alleviating a variety of mental and physical conditions, such as obsessive-compulsive disorder, anxiety, depression and drug addiction. Stress reduction programs have sparked the application of mindfulness ideas and practices (Brown, Ryan \& Creswell 2007). Neuroscience claims that mindfulness practice rewires the brain (Siegel, 2007). Mindfulness training increases activity in the left prefrontal cortex - a predictor of happiness and well-being. And it boosts the immune response, helping to defend against illness (Davison \& Kabat-Zinn, 2003).

Here and now mindfulness and awareness is not a prerogative of Buddhism or medicine. Gestalt psychology is based on the concept of here and now contact rooted in here and now awareness. This includes body sensations, awareness of self and others, of figure and ground and of the active dynamic between these dichotomies. Awareness is a short lived split second flowing phase just as one focuses one's eyes and mind on an object. It takes place before one starts thinking about it, before one's mind says: "Oh, it is." In terms of practice, Gestalt psychology promotes that being in contact with self and other creates change. Simply being open to self and other, changes us (Polster \& Polster, 1974; Orange, 2012). 
Transactional analysis connects its concept of autonomy with relational script-free awareness of the way of making contact with self and other (Berne, 1967; van Beekum \& Krijgsman, 2000). Berne (1972) uses the image of the Martian who comes down to earth, observing without any preconceived notions, only to see and experience the world exactly as it is. Personal construct psychology, a cognitive approach, discriminates between levels of awareness. A high level of awareness shows itself in being aware of what is going on, as and when it is happening. A lower level of awareness shows up when for example one reads something disturbing which makes one feel angry but in the moment one is not sure why (Kelly, 1955/1991).

Psychoanalysis has taught that while we can be fully aware of what is going on in our conscious minds, we have no idea of what information and processes are stored in the pre-conscious and unconscious mind. The pre-conscious contains thoughts and feelings that we are not currently aware of, but which can be brought to consciousness through reflection, therapy and analysis. It exists just below the level of consciousness. The unconscious contains all sorts of disturbing, though significant material, which we often want to keep out of awareness because it is too threatening to acknowledge in full (Freud, 1915).

Based on Buddhist meditation and its application in medicine and clinical psychology, mindfulness is obviously enjoying a growing popularity as a practice for daily life. Over time, the meaning of mindfulness has become more pragmatic than philosophical, varying from mindfulness as a mental state, to mindfulness as a set of skills and techniques. Mindfulness is increasingly seen as a mode of being which can be practiced anywhere, including the workplace. Mindfulness meditation involves using one's senses to help focus one's attention on the present. It focuses on the intentional, accepting and non-judgmental attention to one's emotions, thoughts and sensations occurring in the here and now. Skilful psychotherapy helps to explore the thinking patterns and emotions that emerge during mindfulness exercises so that the source of one's problems can be exposed and new insights can be created.

The Mindfulness Journal, a quarterly academic journal since 2010, publishes peer-reviewed papers that examine the latest research findings and best practices in mindfulness. Its viewpoints include "psychology, psychiatry, medicine, neurobiology, psychoneuroendocrinology, cognitive, behavioural, cultural, philosophy, spirituality, and wisdom traditions" (Mindfulness, 2014). This seems to be a far cry from its original Buddhist's roots but it shows clearly what contemporary mindfulness stands for. And as a result, the business of mindfulness attracts criticism: "The modern description and practice of mindfulness are certainly valuable, as thousands of people have discovered for themselves through their own practice. But this doesn't take away from the fact that the modern understanding of mindfulness departs significantly from the Buddha's own account of sati" (Wallace, 2006). Karnaze writes about the 'mindfulness construct' as a-political, escapist and illusory meditation, used by Westerners to tinker with the next Eastern 'toy', be it yoga or mindfulness. Yet she defends that "mindfulness paves the way for our future. And meditation is a powerful tool that I wouldn't try to replace" (Karnaze, 2014).

Mindfulness has become a trendy movement, a brand, some would argue "an industry, mocked McMindfulness" (Whitaker, 2013), by creating a modern looking, sellable product, modifying old wine in a new bag, integrating philosophical, religious, medical and psychological elements and using Buddha for the goodwill factor.

When 'mindfulness' in its current popularity becomes a movement, we may enter into the dangers of what Jung called mass-mindedness (Jung, 1970). When classical containers of society, like church, family or community loose their influence, people are loosing their roots, become increasingly instable, suggestible and insecure and look for the containment of larger movements for making meaning of their lives. Jung felt that the larger the size of the movement, the greater are the dangers of people being moved by impersonal and overwhelming forces and by herd psychology, because the overall level of consciousness in mass movements is lower. To protect from these external forces, Jung promoted a fundamental inner mind change, which he called metanoia, to be reached by dreamwork.

Regular practice of working with their dreams allows people to discover their inner world. Watching the psyche's creativity and unfolding insights every night in our dreams, helps to lead the "responsible life" that Jung saw as a consequence of individuation, in cohesion with becoming increasingly conscious of our duties to our communities. This metanoia, the fundamental inner mind change, does not take us into isolation or cut off from society, but rather makes us aware of how we all are one in a complexity of interdependence.

\section{Mindful Consulting}

Jung would be the first to focus on a missing aspect in mindfulness, the presence of 'other'. In all of the above mentioned applications, mindfulness is mainly used as a tool for individual health, personal development and spiritual healing, applicable in almost every context but in social isolation as if there is no other. Mindfulness is not seen as a relational quality, nor seen as rooted in early relational patterns. When there is some other it is someone who will benefit later from the cleansing done by the mindful one. Although mindfulness courses include a trainer or a guru, mindfulness operates often as an individual quality, out of context with others, as a baby without a mother. The relational aspect is 
not focused on and hardly mentioned.

Intrapsychic life is driven by thoughts, feelings and all what regulates inner life, on conscious and unconscious levels. Heller (2010) argues that the intrapsychic is embedded in a dynamic intersubjective field. Embedded relational mindful therapy focuses on the therapeutic dyad which is used to understand one's present moment experience of connectedness with the therapist, in the history of one's of early attachment issues. Stolorow adds that the isolated mind is a myth. Intrapsychic material is derived from interpersonal, environmental, linguistic and cultural experiences (Stolorow, 1992). Sullivan adds that "a personality can never be isolated from the complex of interpersonal relationship in which the person lives" (Sullivan, 1940, p.90). The mind is social, the intrapsychic inner world is directly related to its relational context. In a reciprocal evolving process, culture and mind are also emergent from each other. Laing argues that isolated selves are at the core of psychotic and schizoid individuals. In his description of ontological insecurity he describes how isolated individuals do not experience themselves as real or alive, because of lack of relational cohesiveness and consistency, which makes them preoccupied with preserving their own existence (Laing, 1959).

A more relational approach of mindfulness can be found in the literature and practice of consultancy. The client consultant dyad frames mindfulness from the start as a mutual, relational and reciprocal process, in which consultants and clients engage in an ongoing learning process. In other words: the baby hás a mother and both learn in the process. The consultant does not apply a specific mindset to an organisational issue, but enters with the client into the void of an unknown outcome, where unformulated client experience (Stern, 2003) emerges, through a relational experience of curiosity and acceptance or disgust and rejection.

In her introduction of "Mindful Consulting" (White \& Izod, 2009), White uses the wardrobe metaphor to differentiate mindfulness from using different prefabricated mindsets. White equates the consultant using different mindsets for different tasks (e.g. Mintzberg, 2004), with pulling the right costume out of the wardrobe when supposed to be necessary, mostly recreating the same categories for which the wardrobe has supply. In contrast, "mindfulness is about putting together a wardrobe that has the requisite variety for the roles required of a consultant and then making sure that you do not just wear the items that are comfortable" (White \& Izod, 2009, p. XXIX).

In mindful consulting, the consultant and client give up what is familiar and break with known routine, which is exciting, challenging and threatening for both. As such, mindful consulting leans closely to psychoanalytically informed approaches, which extends the work into uncontrollable areas.

Based on the myth of controllability, however, organizations often demand to get quick answers on how-to-manage-things-better-tomorrow questions. They want a well-structured plan, predictable outcomes, and measurable performance indicators. Mindful consultants, especially the more analytically minded, take on the challenge of relating with the deeper complexity and don't succumb to their own and their client's anxieties. On the contrary, they consider it part of their professional ethos to provide the containment for organizations to deal mindfully with complexity and anxiety.

\section{Deep Thinking}

The concept of mindfulness covers a spectrum from an ancient Buddhist meditational attitude via intrapsychic life and relational consulting to a commercial product. To avoid being caught in a fight for the right understanding of mindfulness or for politically correct conceptualization, this paper uses the concept 'mindful' in a generic way, not particularly bound to a school, an approach, a brand or a movement.

Being mindful in essence comes down to allow the experience of deeper thinking, promoted by philosophers, poets and psychologists, even long before Freud. By deeper thinking in the here and now, one is in contact with oneself and other, with one's own and other' deeper sensations, emotions, drives, thoughts, motivations and shadows, including the context in which all this takes place. Deeper thinking as an expression of being mindful is a state of awareness "that enables us to be flexible and receptive and to have presence" (Siegel, 2010).

As a broad generalisation, corporates, executives and senior managers are not easily associated with in depth learning or reflection. This is not a comment by an observant social scientist but is acknowledged in the corporate sector itself. In their book Marketing Metaphoria, Harvard lecturers Gerald and Lindsay Zaltman (2008) discuss the lack of what they call deeper thinking among leaders and managers.

Most contemporary research about organizational behaviour, addresses the conscious level, they write, the visible $10 \%$ of the iceberg. And they argue that deeper insight can only come from making a mindful connection with the more hidden layers of our existence. That more unconscious layer eventually determines our behaviour, it explains why people don't do what they promised to do, why teams sabotage their own jointly taken decisions and why organizations perform under par, despite all good intentions.

There is an anecdote about the late Harvard professor Anthony Athos. When the weather was good, he was often spotted 
sitting under a tree on the campus at the Harvard Business School, with a vague expression on his face. Asked what he did there, his answer was: "Nothing". His Harvard colleagues rolled their eyes and walked away from him, wondering if he was still compos mentis. However, this man was known for his deep insights, thoughts and questions during staff and management meetings. He just took time to think deeper and to be more mindful.

Executive coaches are used to see highflying leaders, managers and ceo's from a variety of industries, who are under daily pressure to make clear, simple, unilateral and fast decisions. In the process of mindful coaching, a meta-level of thinking is introduced as a first step to being more mindful. A second step is allowing more complexity, a third step more time, a fourth step more intrapersonal reflection. In this process the leaders buy time to think, they buy time to be more mindful, in a way that they can interconnect all the four quadrants described by Wilber (1996), the self, the self in relationship, the culture and the collective outcomes. The higher up in the organization this is practiced, the more the whole organization benefits.

The Zaltmans, who are marketing experts, expand this by calling on managers to learn to listen to internal sources of information as 'deep metaphors'. They claim that seven metaphors such as balance (as in work-life balance), transformation (as in sustainable change), travel (as in the travel of life), containment (as in what belongs and what doesn't), connectivity (as in feeling of belonging or being excluded), resources (for survival) and control (have control or let go of control) describe $70 \%$ of our internal emotions and that these are relevant for working in a corporation. Being mindful of them adds value to the work. Other related reading from within the business world can be found in Zaltman (2003) and Sawyer (2006).

\section{Transformation and Leadership}

Wilfried Bion (1961), known for promoting to study unconscious process in social systems, stressed the importance of taking time for reflection. He advised leaders and managers to create emotional space by taking time outs, by making space for relaxation or daydreaming and to eschew memory. He would encourage that professionals engage in activities such as yoga, meditation or tai chi. One could think that a mindfulness training fits in there very well. It is Bion's thinking that leaders and managers need to develop a capacity to contain the anxieties connected to their roles and that they can only do so from a mindful place.

Leaders and managers are in in charge of processes of change and transformation. They often are familiar with the following scenario: the organization has gone through a 'change management process'. This included the definition of goals, extended training days for staff and coaching of management. But, many days and dollars later, everything is still the same. Or they have sent some staff members to a training course from which they returned with new enthusiasm, one could even say that they were 'changed', but in the shortest of times these staff members were back to their previous selves from before the training. Obviously there was some change but then it reverted back to what was before, which in effect meant that nothing had changed.

This is not remarkable because this sort of process is inherent in change: change can be made unchanged and it will happen when the stimulusof the change, like the trainer, the powerpoint presentation or the article, disappears. The used metaphor is the water kettle in the kitchen, heated up to 100 degrees, the water has changed, then turn off the heater and the water will cool down till what is was at the start. Change is temporarily and depending on an outside resource.

In contrast, a consulting process, which focuses on permanent and sustainable change, needs to mobilize internal resources of the organization. This type of change is transformational and essential for every organization that wants to be in the business of continuing innovation. When change can be compared with boiling water, the metaphor for transformation is making an omelette. One mixes eggs and veggies with herbs, adds oil and heat. When the omelette is there, one will never be able to revert the parts back to where it all came from. New connections are made, a new construction, even a new taste. The ingredients have transformed into something new: the omelette. And there is more: to make this new outcome one had to break the eggs, cut the vegies and grind the herbs, and add elements as oil and heat.

When leaders are in charge of a process of transformation, being mindful is the conditio sine qua non. Gutman and Pierre (2000) suggest that in a process of transformation not only conscious but also preconscious and unconscious elements need to be taken into account. Being mindful opens the door for them, it adds practical, mental, emotional and spiritual awareness. This creates a challenge in itself: these unknown elements, which leaders need to be mindful of are always floating, never crystal clear and never finished. Being mindful starts a process which is per definition non-linear, but models a zig-zag path, often uphill.

\section{Characteristics of Mindful Leadership}

A process of transformation needs a high level of awareness and an active mind and once started, it triggers the anxieties that belong to it. When leaders are the executives who carry this process, what makes them successful? Gutman and 
Pierre (2000) have listed characteristics of leadership which are needed to make emerging awareness and anxieties part of their process of reflection and not split them off and project them onto others like the staff, the government or the competitors.

- Good leadership is visionary and shows a desired direction. By having a vision a leader can create an organization that is willing to go an unknown road. Though the vision may be clear, the exact outcome may not be known and that is exactly the reason to follow the path towards that vision. Picasso is supposed to have said: "When you know exactly what the outcome will be, why would you go there it in the first place". The unknown is of interest and creates anxieties, of which leadership has to be mindful.

- Good leadership combines vision with discernment of staying with one's desire with a sharp view. A leader must be able to explain the vision again and again, while taking social, political, economic and spiritual resistance from inside and outside the organization into account. The central question for every leader is: how do I deal with resistance that is created by the fact of me having a vision in the first place. Staying the course demands high relational mindfulness and reflection..

- Good leadership creates good followership. Followers play an active role in the vision of the leader. This sort of following does not come through dictatorial or totalitarian demands but allows the followers to become co-authors of the vision by free will, valued by the main author, the leader. To have and create a followership demands from leaders compassion and love: the leader must be able and mindful to love people, a process that often becomes reciprocal.

- Good leadership is generative and generous. By actively stimulating the own responsibilities of those who follow, leaders give the implicit message that succession is possible and valued. The leader who is conscious about his/her own succession, cares for the staff and shows generosity in thinking of the next generation. Too often we see leaders with highly inflated egos, maintaining the myth that it is all about them and that they are all mighty and in fact immortal. Generosity is an attitude, which demands being mindful.

- Good leadership creates good management and results in a healthy pairing of leader and manager as a working couple. It is the manager's task to organize the means and resources in the organization in such a way that they implement the vision of the leader. It is a shared relationship that can be very powerful en mutually enforcing. To create and sustain such a relationship needs a high level of relational mindfulness.

- Good leadership is the quality to deal with the destructive aspect of anxieties in the organization, expressed by members not being happy. That process needs psychological containment from the leader. It implies that the leader is capable to carry destruction, fear, frustrations and aggressive impulses in the organization, sometime also his own. It needs a high level of being mindful to hold others and oneself in this process while accepting that there will unavoidably be an element of destruction.

- Good leadership, finally, is to be mindful to accept that for the process of transformation, next to the working couple a third is often necessary: the consultant.

The three of them together: leader, manager and consultant, form a sustainable triangle in a transformation process. The consultant is necessary as a bridge between the external world and the internal world, because the consultant represents 'the other', the third eye, the one who brings diversity, newness and difference.

As such the consultant complements and enriches the one-on-one relationship between leader and manager. The consultant can give voice to what cannot be spoken about within the organization. The consultant also brings context, the external, to help shape the understanding within the organization. Therefor the consultant's role is conflictuous by nature and offers a healthy challenge for the tendencies of leaders to see themselves as omnipotent and all knowing. The consultant supports the working couple, to take time and think and...to be mindful.

\section{Implementation}

There seems to be enough reasons for executives to promote and develop the mental state of being mindful with themselves and in relationship with their managers and staff. Following the Zaltman's recommendations (Zaltman, 2008), learning to think deeper and learning mindful techniques is initially easier than what people often think. With focused attention and time one can make a good start. Coyle uses the term "Deep practice [which] feels a bit like exploring a dark and unfamiliar room. You start slowly; you bump into furniture, stop, think and start again. Slowly and a little painfully, you explore the space over and over, attending to errors, extending your reach into the room a bit farther each time, building a mental map until you can move through it quickly and intuitively" (Coyle, 2009 p.78). The difficulty and the challenge is to stay the course, when the process becomes harder, creates frustrations, confronts one with their own shadows or asks for more time. 
When an organization as a whole wants to introduce more time to think deeper and be mindful, an invitation to a mindful consultant to help start the process, is a first step. The consultant's role is indispensable to support and contain the emotional process of deeper thinking and deep practice. The consultant is always under pressure to make fast conclusions or interventions that are designed to make everybody feel better but s/he will not enact on that seduction. A challenge for the consultant is also to be mindful when the company uses mindfulness by stripping it from its (Buddhist) ethical foundations and simply uses it to reinforce corporate greed, aversion, and delusion, which are exactly the three roots of suffering that Buddhists seek to eliminate (Titmus, 2013).

Mindfulness is so popular, that mindfulness trainers (note that a trainer is often not a consultant) are currently asked to hold 45 minutes lunch talks for a groups of corporates to explain what mindfulness is. The invitation manifests the growing interest in mindfulness as a state of mind and its popularity, which can be considered a positive. The risk here is the expectation in the audience of being entertained for 45 minutes and that after 45 minutes everybody 'knows' what mindfulness is. The complementary risk is that the trainer colludes with those expectations. Learning to be mindful is not about slick entertainment, sexy one-liners or so called elevator statements. After all, the value of a process of learning about oneself and oneself in relation to other can only be experienced and not taught, let alone in 45 minutes. It reminds of transactional analysis in its heydays in the 1960s, when founder and top selling author Eric Berne (Games People Play, 1964/1967) was asked to do exactly that: explain in 45 minutes what transactional analysis is. It became the start of a temporary downturn for transactional analysis, because Berne had to make it simple and quickly digestible. It took away the depth and the profoundness of its theory and methodology. What else could Berne present in 45 minutes, other than a watered down version of the theory, philosophy and methodology! It took transactional analysis 20 years to grow out of the then created image of a pop- psychology and reclaim acknowledgement as the respected psychological modality it is.

Purser and Loy likened the current popular implementation of mindfulness techniques in the corporate setting to 'cow psychology,' because contented and docile cows give more milk. "One hopes that the mindfulness movement will not follow the usual trajectory of most corporate fads-unbridled enthusiasm, uncritical acceptance of the status quo, and eventual disillusionment" (Purser \& Loy, 2013).

\section{References}

Berne, E. (1964/1967). Games people play: The psychology of human relationships. London: Penguin Books.

Berne, E. (1972). What do you say after you say Hello? London: Corgi Books

Bion, W. (1961). Experiences in Groups. New York: Basic Books. http://dx.doi.org/10.4324/9780203359075

Brown, K., Ryan, R., \& Creswell, J. (2007). Mindfulness: Theoretical Foundations and Evidence for its Salutary Effects. Psychological Inquiry, 18, 211-237. http://dx.doi.org/10.1080/10478400701598298

Coyle, D. (2009). The Talent Code: Greatness isn't born. It's Grown. Here's how. New York Bantam Books

Davison, R., \& Kabat-Zinn, J. (2003). Alterations in brain and immune function produced by mindfulness meditation. Psychosomatic Medicine, 65, 564-570. http://dx.doi.org/10.1097/01.PSY.0000077505.67574.E3

Freud, S. (1915). The unconscious. Collective works. 14, 159-204.

Gunaratana, B. (2011). Mindfulness in plain English. Boston: Wisdom Publications

Gutman, D., \& Pierre, R. (2000). Consultation and Transformation: Between Shared Management and Generative Leadership. Klein, E., Gabelnick, F. \& Herr, P. (Eds) Dynamic Consultation in a Changing Workplace. Madison: Psychosocial Press p. 3-32.

Heller, M. (2010). Working in Psychological space, using the intersubjective field to access, decode and understand what lies beneath. Inside Out. http://www.insideoutjournal.com

Jung, C. (1970). Civilization in Transition. Bollingen Foundation, Collective works, 10.

Karnaze, M. (2014). The dark side of mindfulness meditation. Mindful Construct. http://mindfulconstruct.com

Kelly, G. (1955/1991). The Psychology of Personal Constructs, 1\&2. London: Routledge. First published by New York: Norton

Laing, R. D. (1959). The Divided Self, and existential Study in Sanity and Madness. London: Tavistock

Mind and Life Institute (2014). http://www.mindandlife.org/dialogues/past-conferences/ml18/

Mindfulness (2014). http://www.springer.com/psychology/cognitive+psychology/journal/12671?detailsPage=aboutThis

Mintzberg, H. (2004). Third generation management development. Training and Development, 158, 28-37. 
Orange, D. (2012). Clinical hospitality: Welcoming the face of the devastated Other. Keynote speech to the New Zealand Association of Psychotherapists' Annual Conference 2012, Wellington, Aotearoa New Zealand

Polster, E., \& Polster, M. (1974). Gestalt therapy integrated. New York, NY: Vintage Books.

Purser, R., \& Loy, D. (2013). Beyond McMindfulness. The Huffington Post. http://www.huffingtonpost.com

Rhys, D. T. (1881). Buddhist Suttas, Clarendon Press.

Sawyer, K. (Ed) (2006). The Cambridge handbook of the learning sciences. New York: Cambridge University Press

Siegel, D. (2007). The Mindful Brain. New York: Norton

Siegel, D. (2010). The Mindful Therapist. New York: Norton

Stern, D. (2003). Unformulated Experience: From Dissociation to Imagination in Psychoanalysis. Hillsdale: The Analytic Press.

Stolorow, R. (1992). The Myth of the Isolate Mind. Contexts of Being, The Intersubjective Foundations of Psychological Life. Hillsdale: The Analytic Press.

Sullivan, H. S. (1940). Conceptions of Modern Psychiatry. New York: Norton

Titus, C. (2013). The Buddha of Mindfulness. A Stress Destruction Program. http://christophertitmuss.org/blog

Van Beekum. S., \& Krijgsman, B. (2000). From Autonomy to Contact. Transactional Analysis Journal, $30,52-57$. http://dx.doi.org/10.1177/036215370003000106

Wallace, B. (2006). The attention revolution: Unlocking the power of the focused mind. Boston: Wisdom Publications

Whitaker, J. (2013). 2013 as the Year of Mindfulness: Critics and Defenders. American Buddhist Perspective. http://www.patheos.com/blogs/americanbuddhist/2013/12

White, S., \& Izod, K. (2009). Mindful Consulting. London: Karnac

Wilber, K. (1996). A Brief History of Everything. Melbourne: Hill of Content Publishing

Zaltman, G. (2003). How Customers Think: Essential Insights into the Mind of the Market. Boston: Harvard Business School Press

Zaltman, G., \& Zaltman, L. (2008). Marketing Metaphoria: What Deep Metaphors Reveal about the Minds of Consumers. Boston: Harvard Business School Press

\section{(cc) $\mathrm{EY}$}

This work is licensed under a Creative Commons Attribution 3.0 License. 


\title{
Reverse Capitalism
}

\author{
Baruch Mevorach \\ Correspondence: Public Policy Department, Tel Aviv University, Israel \\ Received: December 14, 2015 Accepted: December 21, 2015 Online Published: December 25, 2015 \\ doi:10.11114/bms.v2i1.1267 \\ URL: http://dx.doi.org/10.11114/bms.v2i1.1267
}

\begin{abstract}
A rather strange end of history, in Fukuyama's terms (Fukuyama, 1992), is presented in the paper. Backed by the following six paradoxes, the entrepreneur and tycoon are beginning to return to the cozy lap of socialist ideology, while leaving behind their faithful worker, an unwilling prisoner of a cruel and alienated capitalistic ideology.

Entrepreneurs are living in a "No Risk Society", while faithful workers are prisoners of a "Full Risk Society" (Aharoni, 1981).

The six paradoxes, presented hereafter, are as follows:

1. "A negative correlation exists between the amount of time and energy devoted to an organization and the degree of ownership thereof".

2. "A negative correlation exists between the degree of identification with, involvement in, commitment to and loyalty to an organization and the degree of ownership thereof".

3. "Ownership of organizations is not acquired by one's own means. Owners are not really owners in the traditional sense of making purchases using their own money".

4. "The loss of the workplace is devastating for a worker, whereas the direct damage to the owners as a result of going out of business can sometimes be relatively marginal".

5. "In times of affluence, valuations are made on the stock exchange itself, which puts a high value on the companies traded in it; in times of depression, valuations are commissioned from outsiders, and they too traditionally put a high figure on the value of the company ordering the valuation".

6. "The price of a product is particularly high when sold up the hierarchy, from the private to the public company (upward generosity); the price of the same product is particularly low when sold down the hierarchy, from the public to the private company (downward stinginess)".
\end{abstract}

Keywords: full risk society, no risk society, reverse capitalism

\section{Introduction}

One of the fascinating phenomena taking shape before our eyes in recent years is, without a doubt, the transformation of owners into purely virtual figures in their own organizations.

Having found no systematic scientific explanation for this phenomenon in the academic management literature, it has occurred to me that the more appropriate source to have searched from the outset might have been the psychological literature, more particularly the kind that concerns itself with the personality of leaders and figures of illustrious accomplishments.

In the past, owners of the large business organizations in the western world took care to ensure that admiring biographers of their head-spinning success portrayed them as individuals actively involved in running their businesses. Further still, they were described as obsessive, even to the point where their centralistic management and hefty involvement were sometimes seriously detrimental to the very existence of their organizations (March \& Sutton, 1997; Mevorach, 2014).

The entrepreneurial organizational design, taught in every lecture on organizational design, described the business entrepreneur as an individual with a finger in every pie. The entrepreneur was involved in practically every business decision, and it was hard to convince him to confine himself to some area of specialization of his choosing and focus only on that. 
Owners' massive involvement in the active management of their businesses represents the "first wave" in the modern industrial organizational world.

Every MBA student is familiar with Henry Ford and Fredrick Taylor stories (Taylor, 1911, Hutchison, 2005). Taylor, inventor of the functional organizational design, worked hand in hand with his number one client Henry Ford.

In 1918, Ford handed over the presidency of Ford Motor Company to his son, Edsel Ford, even though he retained the final decision authority as chairman of Ford's board of directors.

The "move upstairs" and the control over a board of directors, whose roles comprised of: policy-setting, strategic planning, planning of control and supervision, executives' appointment and pay, the approval of financial statements, structural changes (takeovers and acquisitions, joint ventures, tender offers, etc.) and other matters considered fundamental to a company's business existence, marked the "second wave" in entrepreneurs' degree of daily involvement with their businesses.

As the owners went up to the "second floor", salaried professional managers with a distinguished track record in their respective functional management fields (finances, operations, marketing, human resources, etc.) were nominated in their stead. Each professional manager was given charge of a functional unit manned, in turn, by professionals in the relevant field.

The move "upstairs" allowed owners to relieve themselves of tedious, centralistic, everyday management tasks and free time for running the core of their business in the board's meeting rooms and advance other interests (Henry Ford's Senatorial race in 1918 for example). This represents the "second wave" in the modern industrial organizational world.

The move "upstairs" did not compromise performance in large organizations in any way. Rather, as it turns out, the salaried manager was often able to replicate and even surpass the owners' performance. This finding can be explained in several ways. In functional terms, the specialized manager can be argued to have professional advantages over the owners. In psychological terms, the professional manager, who is not an owner, has the advantage of being emotionally detached, allowing him to remain more cool-headed and financially-minded in making his moves. Another basic and relevant psychological explanation is, without a doubt, the employee's "hunger" and the simple fact that he is fighting for his and his family's economic survival, unlike the owner, who is striving for handsome ROI's and the ability to translate holdings into some level of profitability or another.

As is most commonly the case, it is the explanation combining the above and some other possible causes that is likely to be the one that comes closer to accounting for the phenomenon of the business success achieved by salaried managers.

The appetite of the salaried manager has been satiated by owners with the use of creative reward mechanisms: reward for cost savings, profit sharing, options and ownership shares. All were designed to fulfil the owners' desire to take home larger chunks of profits and drive up the prices of their market holdings in preparation for that much-awaited cash-in day.

The success of hired managers seems to have whetted owners' appetite for free time to such an extent that, in the "third wave", they have started to try removing themselves completely from the organizations they own.

\section{Suggested Paradoxes}

It is not a rarity today to see owners of big banks and holding companies who are not the least involved in managing their businesses. Instead, they hang out in cafes and trendy restaurants, manifesting their involvement in their holdings, at best, with a daily or weekly peek at the newspaper's stock page, to see the value of their holdings, which are traded in different stock exchanges worldwide.

See if you can convince the spirited MBA student to accept the following law of organizational behavior:

1. "A negative correlation exists between the amount of time and energy devoted to an organization and the degree of ownership thereof".

Put differently, of the three major stakeholders in organizations - owners, managers and workers-it is the workers who spend most of their time in the organization, thankful to their bosses for each extra hour of overtime the latter are willing to throw their way, whereas the owners will sometimes omit to even mention one or two holdings they possess, because, with so many of them under their belts, they cannot be bothered with individual holdings.

The new, "third wave" owners are getting close to God: Their spirit frequently pervades the organization, while their person seldom enters its territory, if at all. The "third wave" is characterized by the virtual presence of owners in particularly big organizations, in contrast to the physical presence that had characterized the "first wave" and the intellectual presence typical of the "second wave". 
Table 1. Characteristics of the three ownership waves in the organizational world

\begin{tabular}{lccc}
\hline \multicolumn{1}{c}{ Wave } & First & Second & Third \\
\cline { 1 - 3 } Owners' characteristic & & & \\
\hline Owners' presence & Physical & intellectual & virtual \\
\hline Owners' role & Active CEO & Director / Chairman & holdings trader \\
\hline Owners' involvement & Emotional & rational & speculative \\
\hline Owners' financing & Full & partial & none \\
\hline
\end{tabular}

Now, imagine the toughest, most estranged "first wave" owner. In his everyday work, he frequently rubbed shoulders with his workers, knew them by name and, willy-nilly, would naturally get closer to them and start developing friendly relationships with them at some level or other. The emotional involvement of "first-wave" owners made layoff procedures, justified as they may have been from a managerial and rational standpoint, relatively hard.

"Third wave" owners mainly rub shoulders with the employees and waiters of the cafes and restaurants in which they spend their time swapping, selling and buying all manner of holdings. They do not know their workers, and in some cases are even unable to state the exact number of people they employ in their cumulative holdings. When the name of the game is speculation rather than emotions, what is to prevent owners from completely ignoring their employees' well-being when faced with a lucrative offer to exchange, sell or buy a given holding?

Another interesting paradox relates to the degree of emotional involvement and of organizational commitment and loyalty. While workers and managers are held to emotional involvement in the organization on their part, the organization itself does not undertake, for its part, to be sensitive, committed and loyal towards them. Moreover, come the first "exit" opportunity, the owner is bound to exercise his holdings and abandon the fate of his loyal workers to the new owners, who resemble him in character.

This paradox can be formulated in another interesting law:

2. "A negative correlation exists between the degree of identification with, involvement in, commitment to and loyalty to an organization and the degree of ownership thereof".

It is not rare to see the photos change every few months in the meeting rooms of boards of directors in big holding companies, to reflect frequently changing holdings. Neither is it rare to find directors who have a hard time keeping up with the pace of changes in their holding company.

The workers down the echelon only have a single organization to relate to, whose name and location are very hard to forget, as are the physical and psychological energies it sucks out of them daily.

What occasioned the transition from the "first wave" to the "third wave" in the organizational world and the disappearance of owners of the largest organizations from their premises, the ones they once were so proud to own and to which they dedicated themselves body and soul, the ones they left for their heirs and spent every ounce of energy on?

One explanation could be their recognition of the fact that physical presence ("first wave") and intellectual presence ("second wave") presented no clearly proven advantages. Ownership of an organization in no way testifies to an ability to manage it, set its policies or plan its strategy.

Ownership of organizations has become its own profession. The transition made by tycoons into multiple holdings and diversification of holdings proves this argument. Keeping their distance from the organization is more useful to them than being physically and intellectually close to it.

Owners of organizations need to be distanced, alienated and alert; distanced and alienated from the organizations they own and alert to the noises and opportunities around them. Their energies need to be focused on the next purchase or sale.

Owners are supposed to be oriented towards their environment rather than their organization. The environment is where they will find their next business opportunity. Raising the value of their organization has become a task relegated to salaried directors, managers and employees.

The "third wave" is attended by another interesting phenomenon, which supports the argument that owners are alienated from and not involved in their organizations while being environment-oriented.

The "third wave" is characterized by owners not "bringing cash from home" or not "spending money out of pocket". Diluting an owner's private sources of capital might undermine further acquisitions and holdings, which is why he often looks for external credit. 
It is not uncommon to hear about owners of public companies who used generous bank credit to acquire huge companies, paying no more than five per cent of the purchase value itself out of pocket.

"Outside money" adds paradox to paradox:

3. "Ownership of organizations is not acquired by one's own means. Owners are not really owners in the traditional sense of making purchases using their own money".

We all know the joke about the small-time bank client who cannot sleep at night for fear of not being able to repay the bank his small overdraft. Unlike him, the debtor who has taken out a big loan from the bank sleeps like a baby, leaving the worries to his banker, who remains anxious day and night regarding his solvency.

The money is provided by others, the policy is determined by others, and the work is carried out by others. What remains for the owners to do? Just to be owners!

The damage caused to a worker as a result of managerial failure in his organization, going as far as bankruptcy, is often much greater than the damage sustained by the owner. Since ownership is acquired with generous credit and financial leveraging, the creditors, sometimes even governments, will see to it that the owner does not collapse completely.

Downsizing and layoffs of some of the workers will therefore be tolerated, all in the name of rescuing the capital of the owners and their creditors. As far as governments are concerned, partial efficiency measures, even if they mean letting some of the workers go, are preferable to the total liquidation of an organization, mass dismissals and bankruptcy of the owners, with serious damage to creditors entailed.

A worker's job is often the sole means available to him to fulfil his and his family's existential need. Losing it is often a threat to his physical existence and that of his nuclear family.

The damage to the owners is primarily to their image, but this too, owing to their many holdings, will not usually be particularly significant. If the liquidation of the organization was not attended by criminal offences, such as emptying the company of its assets, the owners are likely to be able to operate in the financial markets with just a little stain to their reputation.

Hence the next interesting paradox:

4. "The loss of the workplace is devastating for a worker, whereas the direct damage to the owners as a result of going out of business can sometimes be relatively marginal".

Business entrepreneurship, one of whose most prominent marks, at least according to conventional thinking, was the love of risk, is increasingly losing this unique trait, judging at least by actual results on the ground. The outcome of failed business entrepreneurship poses much more of a threat to the very existence of the worker employed therein in comparison to the owner, who had seemingly assumed the risk of establishing it to start with.

The business-financial risk assumed is loaded by owners of the large holding companies onto governments and various credit providers, who are concerned for the fate of the business entrepreneurs maybe even more than they are.

It would be interesting to examine, if this has not yet been done by various banking specialists, the amount of or lost or doubtful debt— - debt with a zero or low probability of being repaid —in both absolute and relative terms on the total amounts of credit extended to entrepreneurs as a whole on the one hand and employees as a whole on the other hand.

It can be reasonably assumed that the recent years of global economic recession have raised the relative rate of entrepreneurs' doubtful or lost debts to a great extent, but there is no doubt that the salaried worker's ability to repay debts, especially housing mortgages previously entered into, has also gone down considerably.

In times of affluence, the rising market capitalization of traded companies makes it possible to dilute owners' holdings slightly and pay back the generous bank loans. With companies making handsome profits, it is possible to take out generous dividends, which can also be used to recycle the debt and roll it over for the next acquisition.

Even in times of depression, though, there are many diverse mechanisms protecting owners. Many have the owners' best interest at heart, and would do anything to shield them from business and personal bankruptcy alike: (1) the government, with its fear of having more jobless added to the existing unemployment figures it sees in the economy; (2) the various creditors, who would do anything not to have the credit they had provided declared doubtful or lost debt, such that cannot be repaid and whose very size threatens the existence of the financial institution, the creditor itself; (3) professionals, such as auditors and various financing experts, are also quick to offer their help with beefed-up valuations, for the right money of course, which allow owners to avoid writing off losses on their holdings in different assets.

An auditor who fails to deliver the desired valuations seriously undermines his chances of being commissioned for other valuations. In doing so he is undermining his survivability, since demand for his services drops low anyway during times of economic depression compared to better times. 
The observer of valuation-work orders sees the next interesting paradox:

5. "In times of affluence, valuations are made on the stock exchange itself, which puts a high value on the companies traded in it; in times of depression, valuations are commissioned from outsiders, and they too traditionally put a high figure on the value of the company ordering the valuation".

Additional defense mechanisms that contribute to the survival of owners are the tender offer and the "the bottom-up sale" (e.g. from a private to a public company).

A tender offer allows owners, under certain legal conditions, to change their company's legal status from public to private. The tender offer tries to lure the small shareholder with some premium above the share's current market price in return for his willingness to sell the shares he holds.

While the tender offer means that owners must pay generous sums of money in buying back those percentages of shares they had previously sold to the public, in financial terms they are better off for it at the expense of the small shareholder. The reason for this is that the owners are probably aware of objective reasons that justify a relatively high value for the company they own, and which the public, due to the depression, is afraid to factor into the share price, or right out knows nothing about.

Needless to say, periods of plenty in the economy and the stock exchange are typically replete with public issues, usually overpriced by the owner, while periods of slump therein are replete with tender offers, which pull companies away from the public domain back into private anonymity.

The "bottom-up sale" is likewise mostly prevalent in times of depression. It involves the selling, at a premium, of (1) an owner's private assets to public companies belonging to same owner, or (2) assets belonging to one of the owners' public companies to another of his public companies.

Owners of public companies know how to exhibit a sense of fraternity and camaraderie during recessions and sell assets from one group to the other at prices higher than the going market rates.

Such generous exchanges are rather surprising in view of their toughness and ability to drive a hard bargain during normal times.

In normal times, lo and behold, the opposite phenomenon takes place, which we shall call "top-down sale". This phenomenon is accompanied by over-generosity on the part of public company owners towards private companies they own.

This leads to the sale of relatively high-priced assets at cheap prices and particularly convenient terms of payment by the owners of public companies to the private companies they own, to relatives and to themselves as private individuals.

The trivial and most illustrative example of a "top-down sale" is the sale of a public-company car to its owner after its leasing period at a very easy price. On the other hand, the sale of a private car from the owner to the company will almost always command an appropriate price, if not upwards.

The aforementioned, together with the "downward stinginess and upward generosity" can be encapsulated in the following interesting paradox:

6. "The price of a product is particularly high when sold up the hierarchy, from the private to the public company (upward generosity); the price of the same product is particularly low when sold down the hierarchy, from the public to the private company (downward stinginess)".

These transactions can also be done laterally between stakeholders in different companies who reach especially creative exchange, purchase and sale agreements, in particular during times of depression in the economy and the absence of real economic opportunities. Such roundabout transactions allow them to achieve handsome returns on their capital, all thanks to the camaraderie of their "bros" and on no justified economic grounds.

The defense mechanisms protecting the property and capital of the big holdings owner are diversified. Some are tax-based, others credit-based, and some speculative-amical.

\section{And White-Collar Workers Too}

White-collar workers were quick to respond to the development of the "third wave" mentioned above (their response is hereinafter referred to as the "second work wave"). The white-collar worker possessing skills that are in demand in the labor market nowadays tends to spread risks of his own initiative and diversify his sources of employment in "patchwork" mode, allowing him to better deal with the possible risks of frequent layoffs in an extremely competitive and speculative world.

The work week of the white-collar worker in the "second work wave" is divided between a number of employers, 
employments and different methods of employment.

The white-collar worker in "the second work wave" reduces his dependence on a single employer. He acts as an independent advisor for various organizations, as a part-time worker for one number of hours or another for other organizations.

The "patchwork" method has many tax advantages, allowing the worker to plan the tax levels he pays on the work he does in a way that is more intelligent and worthwhile for him.

Most importantly, the white-collar worker's dependence on the arbitrariness of the owners, whom he often does not know, is diminishing. As owners reduced their level of emotional involvement and increased their level of speculation in their various holdings, the white-collar worker became less emotionally involved in one single workplace, the individual "patch" in the "patchwork" he has sewn for himself. The white-collar worker "trades" his various jobs just as the owners do with their various holdings.

Computer and telecommunication technology allows a very loose physical link to exist between organizations and their employees and compensates, to some extent, the more vulnerable worker for arbitrary layoffs by the owners of the organization in which he is employed.

Table 2. Characteristics of both waves of white-collar/professional work in the organizational world

\begin{tabular}{|c|c|c|}
\hline Wave & First & Second \\
\hline \multicolumn{3}{|l|}{ Work characteristic } \\
\hline Scope of job & full & part-time \\
\hline Physical location & organization & home / office \\
\hline Movement between organizations & forced & mainly voluntary \\
\hline Employee involvement & emotional & rational / speculative \\
\hline Employment status & employee & employee and/or independent \\
\hline
\end{tabular}

The competitive white-collar worker in the "second work wave" in many cases arranges his occupational "patchwork" in descending order of extrinsic and intrinsic rewards available in his various places of employment, deciding whether to leave or stay accordingly.

The most extreme example of "second work wave" characteristics is inherent in chairmen of public companies' boards of directors who are not in-house salaried workers of the companies they head.

They are defined, for income-tax purposes, as consultants to the companies they head, using invoices to charge these companies their fees, as would any external consultant.

This kind of employment of the most senior non-owner managers and directors in organizations represents a mutual interest. The owners are keen to save themselves the social contributions required under other modalities of employment, while the worker or professional manager prefer billing the company expensive hours while managing themselves their contributions towards pensions and various insurances through independent consultancies they own.

The "hot desking" employment method, which once referred to flexible and part-time employment of salaried workers in various organizations, is currently shifting to the homes of white-collar workers.

If the term "hot desking" once referred to a number of employees working around one table, today it is becoming increasingly characteristic of a different format: white-collar professionals seated at the home "hot desk"- a single desk from which they work for several organizations they serve.

The white-collar worker, perhaps in imitation of the big holding owners, is also becoming, like them and to a large extent, an entirely virtual and emotionally-detached figure in the organizations to which he provides consulting services in different areas.

Various tax reforms privileged professional freelance work over salaried professional work in two respects. One was the ability to withdraw low tax dividends from a company without paying any personal income tax on them. The other was the substantial tax differential between corporate and personal taxes, in favor of corporate taxes of course.

The white-collar professional is in fact turning into a holding company, except that his holdings are his attention and intellect as divided between different companies for which he works and acts as consultant to.

The considerations made by the white-collar worker in deciding whether to stay or leave, and whether to reduce or increase his contribution to a given organization, are somewhat similar the those made by owners of big holding companies, except that instead of relating to returns on capital, they have to do with returns on the intellectual capital he 
provides to his various holdings.

The white-collar professional and the owner of a big holding company are a relatively rare breed of people possessing financial capital and intellectual capital that are in demand. The first is protected by the potential intellectual damage that his departure would cause to the company in which he is employed; the second is protected by the potential damage of his departure to the company, to creditors, and to the state in general.

\section{Epilogue}

The truly defenseless and the true risk takers are, ultimately, the line and service workers, whose work is not unique or particularly critical for their organization. They can be quite easily replaced, and this can be done relatively fast without much investment in training and development.

This kind of employee is increasingly losing the state's protection, on which he used to rely, in an alienated capitalistic world geared now, more than ever, towards protecting owners of substantial capital. It is during the very period when real unemployment figures in the western world are and will probably be on the rise that the salaried worker is losing significant insurance components that once protected him, and all this in favor of the tycoon who is harnessing ever greater state resources in favor of his own financial protection.

The end of ideology is to a great extent the end of the legitimacy given to the masses to enjoy various insurance mechanisms and the strengthening of the same legitimacy for the few initially well to do, whose attachments to and availability in the organizations they own are diminishing (Paradoxes 1 and 2 above).

A stranger observing the capitalistic western culture will witness an interesting phenomenon with far-reaching implications. The tycoon is the new wretch, who receives all manner of state and other protections while leaving his loyal worker more or less devoid of state protections, and significantly so compared to the past.

This is, undoubtedly, an upside-down world. Owners are getting closer to God. They have left their organizations, lost touch with their employees, and are willing, today more than ever, to consider downsizing as an initial and primary tool for dealing with economic crises. Their loyal employees invest more and more in trying to cope with the global financial crisis, while losing layers of defense and insurance such as salary levels, adequate social benefits, the protection of worker committees and trade unions and suffering from reduced caution in massive and rushed dismissals.

The owners, being entirely virtual figures in their organizations, will be able to devote more and more free time to governmental interfaces, in order to acquire increasingly more defenses and insurances. The junior employee will give up increasingly more time and money resources to ensure his employment while increasingly losing different kinds of defenses and insurances.

It is the strange end of history indeed. The entrepreneur and tycoon is beginning to return to the cozy lap of socialist ideology, while leaving behind his faithful worker an unwilling prisoner of a cruel and alienated capitalistic ideology that robs him of intellectual, time and money resources in his efforts to survive in a world of employment that is possibly more ruthless and competitive than the world of organizations and their ownership.

\section{Bibliography}

Aharoni, Y. (1981). The No-Risk Society, Chatam House. ISBN 10:0934540063/ISBN 13:9780934540063

Fukuyama, F. (1992). The End of History and the Last Man, Free Press. ISBN: 0-02-910975-2

Hutchison, M. (2005). Big Ideas in US History. Kerry Gordonson, Editor; Dr. Aaron Willis, Project Coordinator, Culver City, California: Social Studies School Service. ISBN: 1-56004-206-0

March, J. G., \& Robert, I. S. (1997). Organizational Performance as a Dependent Variable. Organizational Science, 8(6), 698-706. http://dx.doi.org/10.1287/orsc.8.6.698

Mevorach B. (2014). Soldiers and Priests in Business Administration. Quality and Quantity, 6, 2649-2654. http://dx.doi.org/10.1007/s11135-014-0133-5

Taylor, F. W. (1911). Principles of Scientific Management, Harper \& Brothers publishers. ISBN 0-415-27982-8 (set) ISBN 0-415-27983-6 (Vol. 1) 


\title{
Time Error in Project Management: A Case Study in Yanbu, Saudi Arabia
}

\author{
Umar Ammar Altahtooh \\ Correspondence: Umar Ammar Altahtooh, Taibah University, Yanbu, Saudi Arabia
}

\author{
Received: November 30, 2015 Accepted: December 16, 2015 Online Published: January 4, 2016 \\ doi:10.11114/bms.v2i1.1277 \\ URL: http://dx.doi.org/10.11114/bms.v2i1.1277
}

\begin{abstract}
Time error is a reality in the majority of projects. This paper presents empirical research which investigates the influence of time error during project life cycle. Data were collected using interviews with project managers and analyzed using content analysis. The findings explore the causes of time error in projects in Yanbu, Saudi Arabia. This study gives an introductory insight into the influence of time error. It finds that time error affects the triple constraints of project management.
\end{abstract}

Keywords: project, Saudi Arabia, time error

\section{Introduction}

Saudi Arabia is one of the richest countries in the Gulf Cooperation Council (GCC). It has invested a lot of money in projects in Yanbu, which is an industrial city and a petroleum shipping site by the Red Sea. Most of these projects have overrun in terms of timescale. This paper is exploratory and qualitative in nature, and the case study data were collected through interviews. The aim of the study is to provide an overall perspective on the impact of time error on projects by exploring the following question:

- What is the influence of time error on projects?

According to Altahtooh and Emsley (2014), time error can happen throughout the project execution phase. In order to answer the above question, the researcher gathered data from interviews. Then, a content analysis was used to analyze the data from 13 project managers.

The next section of the paper gives an overview of project life cycle and time management. Following this, the research method is described, and then the results are discussed. Finally, the findings are summarized.

\section{Literature Review}

It is not easy to conduct a literature review of time error because it is still a new concept in the project management field. However, time error can occur during project life cycle and time management.

\subsection{Project Life Cycle}

One of the most important elements of project life cycle is time. Thus, the definition of 'project' is mainly centered around time. According to PMBOK ${ }^{\circledR}$ Guide (Project Management Institute, 2008), a project is "a temporary endeavor undertaken to create a unique product, service or result" (p.5). "Temporary" means a project has a definite beginning and a definite end. Project life is constrained by "a fixed schedule" (Ramakrishnan, 2009). Regarding construction, project life cycle means "the period spanning from project formulation to construction completion" (Gransberg, 1999, p.9). In project management, it is defined as a collection of project phases (Project Management Institute, 2008). There are four phases of project life cycle:
1. initiating
2. planning
3. executing
4. closing

According to Boyde (2015), there are two standard project life cycles:

- Linear/Waterfall Model (Figure 1) 


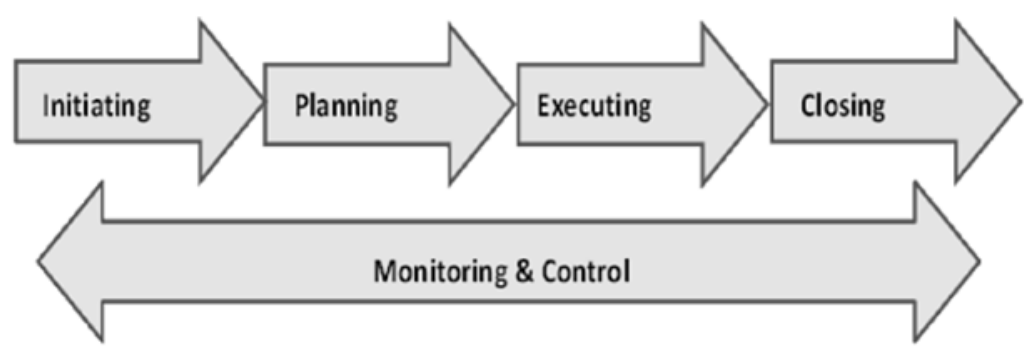

Figure 1. Waterfall Model (Source: Boyde, 2015)

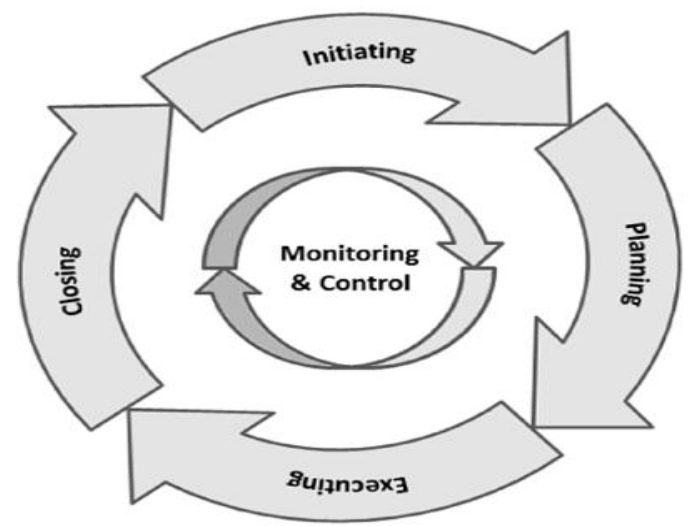

Figure 2. Agile Modelling (Source: Boyde, 2015)

The Waterfall Model is a linear process that moves from one phase to the next while Agile Modelling is an iterative process. Simply, a project life cycle is described as project phases relative to time. Thus, time management is required in project management.

\subsection{Time Management}

The guide of PMBOK has a chapter about time management which is related to:

- Defining the activities

- Sequencing the activities

- Estimating the activities resources

- Estimating the duration of the activities

- Developing the schedule

- Controlling the schedule

The above six elements are related to "Activities Chain Management" or "Activities Management", but it is named "Time Management". This indicates the importance of time in project life cycle. Time is the first element of the triple constraints, so time management is not easy for the project team, and indeed it is a very challenging task. Altahtooh and Emsley (2014) introduce some terms that are related to time management:

- Accepted Time Project Delay

- Accepted Time Project Advance

- Time Error Project Correction

- Authorized Project Duration

- Actual Project Duration

Time error is the difference between the actual project duration and the authorized project duration. This term is recently developed by Altahtooh and Emsley to determine the outcomes of a project.

\section{Method}

The aim of interviewing project managers was to collect rich qualitative data about the influence of time error on projects. The interviews were conducted with 13 project managers in Yanbu, Saudi Arabia. In this qualitative case study, 
data were collected through structured interviews. A pilot study was done to test the reliability of the interview questions and the feasibility of the case study. The goal of conducting the pilot study was to improve the questions so that they were clear and concise. None of the interview questions required the disclosure of confidential information.

The project managers were interviewed for between 50 and 60 minutes between 7th July and 12th August 2015. The interviews were carried out in their offices. To overcome any form of constraints in this case study, each participant was asked the same questions. With the prior consent of the interviewee, the structured interviews were recorded and transcribed. The Arabic interviews were transcribed and translated into English.

Thus, the outcomes of these interviews examined using as content analysis and presented in the form of themes by identifying the most frequent responses and analyzing narrative data to explore the influence of time error on projects as described below.

\section{Results}

Content analysis is used for exploratory and explanatory research; however, it is most often used in descriptive research (Neuman, 1997). Qualitative content analysis is defined as "the systematic and objective procedure used to identify and analyze significant written, verbal or visual data in order to tabulate, classify, summarize and compare the contents" (Seamen, 1987). The transcripts were analyzed using content analysis to answer the research question. The design of the data analysis process is as follows: a) analysis, b) interpretation, c) synthesis, d) documentation (Ptacek, 2009).

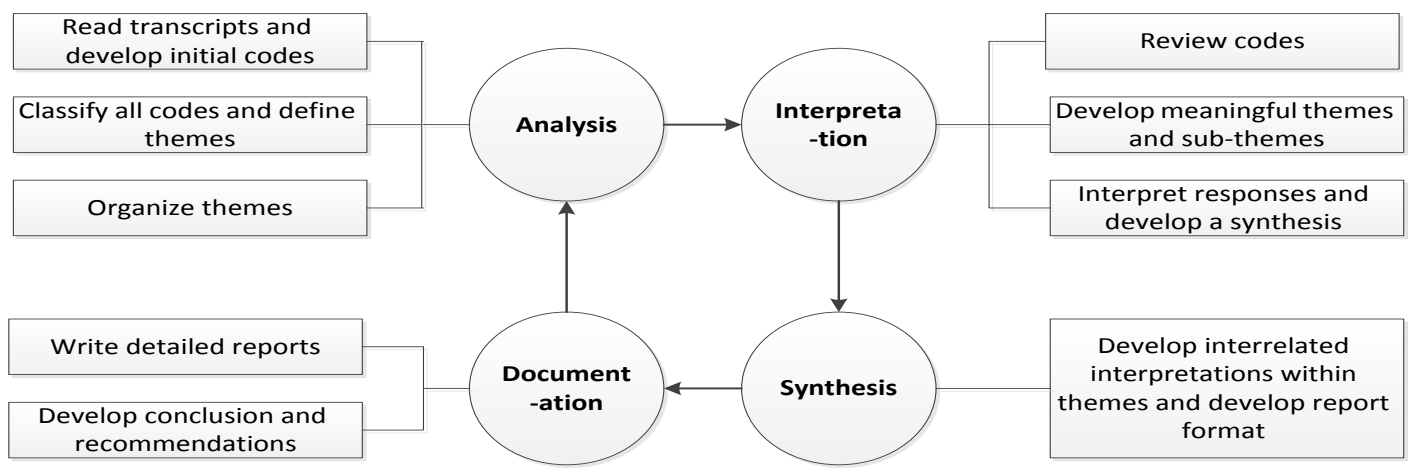

Figure 3. Data Analysis Process (Adapted from: Ptacek, 2009)

\subsection{Profile of Project Managers}

In terms of nationality, four of the project managers were Saudi while nine were non-Saudi. As seen in Table 1, eight of the interviewees were in their forties while five were in their thirties. Eleven of the participants in the interview sample had completed a bachelor's degree, while two had completed a master's degree. In terms of industrial field, four of the participants were from the construction field, three were from the petrochemical field, three were from government, two were from the IT industrial field and one was from the telecommunication field. Two of the project managers had more than 10 years' experience in supervising projects, eight had between 5 and 10 years' experience and three had less than 5 years' experience. The range of the number of projects that the interviewees had been involved in as a project manager was between one and six.

Table 1. Project Managers' Profiles

\begin{tabular}{ccccccc}
\hline $\begin{array}{c}\text { Project } \\
\text { Manager }\end{array}$ & Nationality & Age & $\begin{array}{c}\text { Education } \\
\text { Level }\end{array}$ & Industrial Field & $\begin{array}{c}\text { Number of Years' } \\
\text { Experience in the Field }\end{array}$ & $\begin{array}{c}\text { Number of Projects } \\
\text { as PM }\end{array}$ \\
\hline PM01 & Non-Saudi & 47 & Bachelor & Construction (C) & 11 & 5 \\
PM02 & Non-Saudi & 42 & Master & Petrochemical (P) & 8 & 4 \\
PM03 & Saudi & 40 & Bachelor & Petrochemical (P) & 8 & 3 \\
PM04 & Non-Saudi & 38 & Bachelor & Construction (C) & 4 & 2 \\
PM05 & Non-Saudi & 44 & Bachelor & Construction (C) & 8 & 7 \\
PM06 & Non-Saudi & 39 & Bachelor & Telecommunication (T) & 13 & 4 \\
PM07 & Non-Saudi & 48 & Bachelor & Petrochemical (P) & 4 & \\
PM08 & Saudi & 35 & Bachelor & IT (IT) & 3 & 4 \\
PM09 & Saudi & 31 & Bachelor & Government (G) & 8 & 4 \\
PM10 & Saudi & 40 & Master & Government (G) & 9 & 4 \\
PM11 & Non-Saudi & 43 & Bachelor & Construction (C) & 5 & 4 \\
PM12 & Non-Saudi & 38 & Bachelor & IT (IT) & 9 & 4 \\
PM13 & Non-Saudi & 49 & Bachelor & Construction (C) & \\
\hline
\end{tabular}




\subsection{Time Error in Project Management}

In this section of the analysis, the interview questions were asked in order to explore time error in projects from the perspective of project managers, focusing on the following aspects:

- definition of time error in project management

- causes of time error in project management

- influence of time error on projects

The next section shows the responses of participants to all of the above elements regarding time error.

\subsubsection{Definition of Time Error}

This study seeks to introduce a practical definition of time error in project management. The researcher asked the participants - as the first question of the interview - the following: What is time error in project management?

The aim of the above question is to understand the nature of time error according to the explanations given by the project managers. The following answers show their understanding in different ways about time error in project management.

Nine project managers believe that time error leads to a project delay, as shown in the following answers:

"I'm not familiar with this term [time error] but I think it is a type of delay" PM03.

"Let me say this time error is definitely real in projects, and it is somehow related to delay" PM09.

"It [time error] is a delay time that can happen during a project life cycle" PM01.

"It's an interesting question; let me say that the sum of time errors during a project life cycle leads to a delay in project management" PM10.

"I don't use this term [time error] very often. For me it [time error] means a delay in project schedules" PM11.

"I believe that time error is a delay in project completion time" PM07.

"I think any delay in project work can be defined as time error in project management" PM13.

"Time error is a delay in project delivery" PM04.

"I think any mistake in project schedule means delay or time error" PM05.

According to the above answers, this group of project managers has a general view about time error in project management which is related to delay time in project completion. They represent about $69.2 \%$ of the interview sample in Yanbu, Saudi Arabia. Delay is the keyword which is used to define time error in project management by these project managers.

Four project managers think that time error is an uncertainty that may contribute to project schedule problems, as shown in the following responses:

"I think time error is an uncertainty factor which cannot be estimated due to many reasons" PM02.

"I think no one can give an accurate definition for time error in project management, but it [time error] can occur if there is an uncertainty during the decision-making process" PM06.

"I can define time error as an issue of uncertainty in project time management" PM12.

"Time error is a result of trying to eliminate or reduce an uncertainty in project planning" PM08.

Regarding the above responses, this group of project managers links time error with uncertainty in project management. They represent about $30.8 \%$ of the interview sample. Uncertainty is the primary factor in defining time error according to this group. In this section, a common definition of time error is introduced by project managers. The next section presents the causes of time error in project management.

\subsubsection{Causes of Time Error in Project Management}

It is important to identify the causes of time error before discovering its influence on projects. The next interview question for the project managers was: What are the causes of time error in project management?

The answers were analyzed to explore the causes of time error. The replies can be classified into two categories: 1) time error due to managerial factors and 2) time error due to technical factors.

Table 2 summarizes the causes of time error identified by the project managers in Yanbu, Saudi Arabia. 
Table 2. Causes of Time Errors

\begin{tabular}{|c|c|c|c|c|}
\hline No & Causes of Time Error & Managerial & Technical & Industrial Field \\
\hline 1 & Lowest bid wins & $\bullet$ & & $(\mathrm{G}),(\mathrm{C})$ \\
\hline 2 & Changes in orders & $\bullet$ & & (C), (IT) \\
\hline 3 & Poor communication & $\bullet$ & & $(\mathrm{IT}),(\mathrm{G}),(\mathrm{C}),(\mathrm{P})$ \\
\hline 4 & Turnover & • & & (IT), (G) \\
\hline 5 & Shortage of labor & - & & $(\mathrm{C}),(\mathrm{P})$ \\
\hline 6 & New technology & & • & (P), (IT) \\
\hline 7 & Poor leadership & $\bullet$ & & $(\mathrm{C}),(\mathrm{G}),(\mathrm{P}),(\mathrm{IT})$ \\
\hline 8 & Conflict and friction between client and contractor & $\bullet$ & & $(\mathrm{C}),(\mathrm{P})$ \\
\hline 9 & Late payments to contractors & $\bullet$ & & $(\mathrm{G}),(\mathrm{C})$ \\
\hline 10 & Poor design & & • & $(\mathrm{C}),(\mathrm{G}),(\mathrm{P}),(\mathrm{IT})$ \\
\hline 11 & Unrealistic time schedules & & • & $(\mathrm{C}),(\mathrm{P}),(\mathrm{IT}),(\mathrm{G})$ \\
\hline 12 & Litigation issues & $\bullet$ & & (C), (G) \\
\hline 13 & Misunderstanding end-user requirements & $\bullet$ & & (IT) \\
\hline 14 & Wrong testing tools & & - & (P), (IT) \\
\hline 15 & Bad coding practices & & $\bullet$ & (IT) \\
\hline
\end{tabular}

As shown in Table 2, ten causes of time error in project management are managerial factors and five are technical factors. In this case study, four causes of time error (poor communication, poor leadership, poor design and unrealistic time schedules) occur in all industrial fields (C, G, P, IT). Two causes (misunderstanding end-user requirements and bad coding practices) are limited to the IT industry. Thus, identifying the causes of time error can help project managers to take precautions against them. The next section presents the influence of time error on projects.

\subsubsection{The Influence of Time Error}

In the above section, the causes of time error in project management are identified by 13 project managers in Yanbu, Saudi Arabia. The third interview question for the participants was: What is the greatest effect of time error on projects?

The aim of the above question is to determine the influence of time error on projects. In exploring the influence of time error, the answers of project managers focus on the following elements:

- schedule

- cost

- scope

These elements are the triple constraints of project management. The following replies show how time error can directly affect project schedule:

"I think that the greatest effect of time error on a project is the scheduled shift start time and end time of activities" PM08.

"If time error happens in project execution, this means a scheduled delivery time will be late" PM02.

"The effect of time error on the project includes time and cost overrun" PM12.

"Let me say that time error associated with poor time management leads to many schedule issues in the project" PM06.

"At all times the suppliers are responsible for providing raw materials on time, but in many cases they fail, and as a project manager, this case is an example of time error" PM03.

"I think that time error can happen because of unimportant meetings, and of course, those meetings may lead to schedule problems" PM05.

"The margin of time error varies from case to case in the project, but the sum of cases can affect project schedule based on the size of margin" PM01.

"I think that one time error after another during the project's life can have a negative effect on time management" PM07.

The following responses show how time error can affect project cost:

"So more time errors mean more faults in budget estimate" PM04.

"Also, I think that time error is costly for any project" PM10.

"The effect of time error on the project includes time and cost overrun" PM12.

"Sometimes a project manager does not care so much about time error, but project cost will need to be estimated again" PM09. 
According to the above responses, time error has a clear effect on: i) project schedule and ii) project cost. However, it has a clearer effect on schedule. Only one of the project managers mentioned the effect of time error on project scope.

The following response shows how time error can affect project scope:

"From my experience, any error of time causes a pressure on everyone and everything to do with the project, so in many cases project scope is affected by this time error" PM13.

The next section presents the discussion and conclusions.

\section{Discussion and Conclusions}

This study aims to investigate the influence of time error on projects in Yanbu, Saudi Arabia, as a case study. It makes a valuable contribution to the literature on time error in project management research. Indeed, this paper is the first attempt to empirically examine the influence of time error on project. Based on the definitions given by the project managers in section 3.2.1, time error is a new term in the project management field. The majority of project managers in the sample think that time error in project management is a cause that leads to delay while some think that it is a result due to an uncertainty. The next figure show the relationship of three terms: time error, delay and uncertainty.

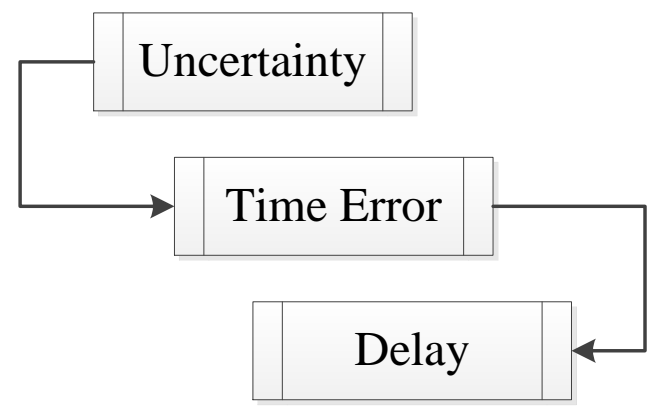

Figure 4. Definition of Time Error

As shown in Figure 4, it is clear that time error is not totally delay or uncertainty. Time error occurs after uncertainty and before delay. Thus, the justification of this definition is that when uncertainty leads to errors during project life cycle, time error occurs. However, this time error will be involved in two scenarios: a) undelayed project delivery when time error is solved and b) delayed project delivery when time error is unsolved. Also, uncertainty does not lead directly to delay.

The causes of time error are classified as follows:

a) managerial causes:

- lowest bid wins

- changes in orders

- poor communication

- turnover

- shortage of labor

- poor leadership

- conflict and friction between client and contractor

- late payments to contractors

- litigation issues

- misunderstanding end-user requirements

b) technical causes:

- new technology

- poor design

- unrealistic time schedules

- wrong testing tools

- bad coding practices

The influence of time error on projects can affect the following elements:

- schedule

- cost

- scope 
This paper adds more knowledge to the understanding of time error. No prior study has been undertaken on the effect of time error. Thus, in determining the effect of time error in project management in Yanbu, Saudi Arabia, this is an original study. It is very important that more research about time error in project management is carried out. It is significant to note that time error is a new concept in the field of project management. The limitation of this study is that the sample of project managers is small, but it presents an introduction so that academics can do further research on time error in project management.

\section{References}

Altahtooh, U., \& Emsley, M. (2014). Is a Challenged Project One of the Final Outcomes for an IT Project? System Sciences (HICSS), 2014 47th Hawaii International Conference on (pp. 4296-4304). IEEE. http://dx.doi.org/10.1109/hicss.2014.531

Boyde, J. (2012). A Down-To-Earth Guide To SDLC Project Management: Getting Your System/Software Development Life Cycle Project Successfully Across the Line Using Pmbok adaptively (2nd ed). Available at http://books.google.com

Gransberg, D. D. (1999). The Cost of Inaction: Does Massachusetts Need Public Construction Reform?. Pioneer Institute for Public Policy Research, Center for Restructuring Government, White Paper No. 7, Boston, Massachusetts.

Neuman, W. L. (1997). Social research methods: Qualitative and quantitative approaches. 3rd ed. Needham Heights, MA: Allyn and Bacon.

Project Management Institute. (2008). A Guide to the Project Management Body of Knowledge (PMBOK® Guide). 3rd ed. USA.

Ptacek, C. (2009). Using morphological content analysis to mine insights from qualitative interviews. Available at http://www.quirks.com/articles/2009/20090304.aspx

Ramakrishnan, S. (2009). Innovation and scaling up Agile software engineering projects, Issues in Informing Science and Technology, Volume 6, 557-574. http://iisit.org/Vol6/IISITv6p557-574Ramakrishnan573.pdf

Seamen C. H. C. (1987). Research Methods-Principles, Practice and Theory for Nursing. Norwalk, CT: Appleton and Lange.

\section{$(\mathrm{cc}) \mathrm{BY}$}

This work is licensed under a Creative Commons Attribution 3.0 License. 


\title{
Sustainable Development through Knowledge Management on the Example of Public Utilities Enterprise in IT Environment
}

\author{
Izabela Sztangret \\ Correspondence: Izabela Sztangret, Ph. D, University of Economics in Katowice, Poland \\ Received: December 22, 2015 Accepted: December 30, 2015 Online Published: January 8, 2016 \\ doi:10.11114/bms.v2i1.1293 \\ URL: http://dx.doi.org/10.11114/bms.v2i1.1293
}

\begin{abstract}
Identifying the sustainable development with eco-development and the principles of the concept of social welfare in the long term (strategic), with particular emphasis on the economic and environmental efficiency projects, it is worth to pay the attention to the implementation of these rules to the utilities sector. This problem becomes particularly important in the era of the Information Society and the knowledge economy, where the skillful management of the diffusion of knowledge in subsystems of partners relations platform will foster communities of creators eco-values and commercial values. The purpose of this article is identification of ways to implement the concept of sustainable development through knowledge management in the eco-system of the chosen company, a regional leader in the municipal services sector and its partners, in IT environment.
\end{abstract}

Keywords: sustainable development, knowledge management, holistic model

Kod JEL: L14

\section{Introduction}

Sustainable development is frequently identified with eco-development and the principles of the concept of social good in strategic perspective, with special focus on economic and environmental effectiveness of ventures (Cash, Clark, and othr., 2003; Kristjanson, Reid, Dickson, and othr. 2009). It seems that special attention should be paid to the method of implementation of these principles by enterprises from the sector of public utilities. The problem of sustainable development is gaining importance in the period of Information Society, knowledge economy and developing environment of IT solutions where skilful knowledge management, particularly its diffusion in sub-spheres of relationships with stakeholders, favours establishment of the platforms of creators of eco-values and commercial values.

Sustainable development also referred to as stable development or eco-development is a concept in economics that presumes the level and quality of life to be the level as guaranteed by civilizational development in particular time. The idea of sustainable development is summarised in the first sentence of WCED (The World Commission on Environment and Development, also referred to as „Brundtland Commission”) report of 1987 - „Our Common Future”: "On current civilizational level sustainable development is possible. Sustainable development is development that meets the needs of the present without compromising the ability of future generations to meet their own needs". This definition is based on two fundamental notions: the notion of ,needs”, particularly elementary needs of the poorest in the world that should be prioritised, and the notion of limitations, i.e. imposed capabilities of the environment to meet present and future needs through the level of technology and social organisation. The content of the report suggests that achieved civilizational level is possible to be retained on condition of appropriate management in the sphere of economics, environment and social welfare. According to the opinion of the Club of Rome, included in the report entitled „Limits of Growth", sustainable development of all spheres of human life and activity should be taken care of for the purpose of ensuring further existence of life on Earth and possibilities to meet elementary needs of all the people and future generations. It results from the definition included in standards and also documents of the United Nations that sustainable development of Earth is the development that meets elementary needs of all the people. It preserves, protects and restores health and integrity of Earth eco-system without a threat to the possibility to satisfy the needs of future generations and without exceeding long-term limits of the capacity of the Earth ecosystem (Stappen, 2006).

Therefore Sustainable development represents such an economic growth that leads to social coherence and increase in the quality of natural environment (Gerwin, 2008; Kozłowski, 2005). In Poland the principle of sustainable development is included in clause 5 of the Polish Constitution (Konstytucja Rzeczypospolitej Polskiej' Constitution of Poland), whereas 
the definitions of sustainable development is comprised in the Act entitled Environmental Protection Law in the following wording: [it is] such social and economic development in which the process of integration of political, economic and social activities is observed, with maintenance of natural balance and durability of elementary natural processes, for the purpose of ensuring the possibility to satisfy elementary needs of individual communities or citizens of both present and future generations (Ustawa z dnia 27 kwietnia 2001 r. Prawo ochrony środowiska: [Act of 27th April 2001 Law of environment protection] Dz. U. [Official Journal of Law] of 2001).

The ways of implement of the concept of sustainable development through knowledge management is very important in the eco-system of the chosen company, a regional leader in the municipal services sector and its partners, in IT environment. It is supposed that, the model of sustainable development through knowledge management in researched firm and partners is multi-subject, multifunctional and multi-tool.

\section{Data and Methodology}

The goal of the paper is to identify the ways of implementation of the concept of sustainable development through knowledge management in the eco-system of relationships of an example public utilities enterprise and its network partners in the environment of IT solutions.

In-depth case analysis is one of the methods applied in the research ${ }^{1}$. This method consists in a comprehensive presentation of a real situation occurring in a particular company or in regard to one of the functions realized within the company (e.g. sustainable development through knowledge management), which is treated as an individual case. It involves seeking for all necessary data enabling its in-depth analysis, formulating possible choice options and making the best possible decision, accompanied by a proper justification. The subject of research is Master - Odpady i Energia Sp. Z o.o. [Master - Waste and Energy PLC] in Tychy that provides complex services in the sphere of collection and management of municipal waste. It is one of the leaders in this sector, in Poland. It has the status of regional installation for region IV of Śląskie voivodeship. During research direct interviews with mangers of Master and its consortium members were conducted. Furthermore, websites of the companies providing municipal services and the trade organisations such as Krajowa Izba Gospodarki Odpadami [National Chamber of Waste Management] (KIGO), Polska Izba Gospodarki Odpadami [Polish Chamber of Waste Management] (PIGO), Stowarzyszenie Polskich Przedsiębiorców Gospodarki Odpadami [Association of Polish Waste Management Entrepreneurs], Ogólnopolska Izba Gospodarcza Recyklingu [All-Poland Economic Chamber of Recycling] and Polska Izba Ekologii [Polish Ecology Chamber] were analysed. Specialist trade journals of IT sector, mainly Computerworld magazine and annual issues of Computerworld TOP 200 from the period between 2000 and 2015 were also reviewed.

Table 1. Basic information about performed research

\begin{tabular}{|c|c|}
\hline Specification & Characteristics of performed study \\
\hline Research technique & $\begin{array}{l}\text { analysis of Internet pages, analysis of sponsored interviews in journals, direct } \\
\text { interviews, analysis of rankings in Computerworld TOP200 }\end{array}$ \\
\hline Sample selection & purposeful selection \\
\hline Sample size & $\begin{array}{c}1 \text { promoters of network relationship (MASTER - Odpady i Energia Sp. z o.o. } \\
\text { in Tychy) }\end{array}$ \\
\hline Criteria of selection of sample group & $\begin{array}{c}\text { The best } 200 \text { IT firms selected by Comuterworld TOP200 } \\
\text { purposeful selection, typical entities }\end{array}$ \\
\hline Spatial range of research & Poland and global range \\
\hline Time range of research & $2000-2015$ \\
\hline
\end{tabular}

\section{Sustainable Development through Knowledge Management}

The concept of sustainable development is becoming particularly important in the period of knowledge society and knowledge economy where knowledge is the reason and a driving force for comprehensive development of individuals and all economy (Roblek., Meško, and othr., 2014). In this context the notion of sustainable development, in business

\footnotetext{
${ }^{1}$ Application of the method seems justified because:

$1 /$ research concerns contemporary, dynamic phenomena and knowledge about these phenomena that is being formed;

$2 /$ it concerns research of real contexts of these phenomena at large ambiguity of borders between the very phenomena and their contexts;

$3 /$ the subject of the research is too complicated to explain cause and effect relationship by means of the survey method or experiment. (Perry, 2001; Żabińska \& Żabiński, 2007).
} 
environment is often approached as the synonym of behaviours associated with success and innovativeness ${ }^{2}$, often of pro-ecological character in relationships with various groups of stakeholders, in the process of creation of systemic values ${ }^{3}$, in IT environment.

The concept of sustainable development implemented by the entities of network relationships in knowledge environment fits in the model of holistic knowledge management (SET KM Model) that is based on three pillars: (1) company strategy, i.e. strategic concept of organisational awareness, knowledge and learning, (2) environment of knowledge creation, co-sharing and application that is dependent on the company and its partners, and on objective determinants, (3) knowledge tools that are conducive to processes of effective management, including knowledge diffusion (Choo, 1998; Nonaka \& Konno, 1998; von Krogh, Ichijo \& Nonaka, 2000; Neto, 2008).

Systemic relationships (Creech, Willard, 2001) with all entities of the environment of sustainable value creation, established on the basis of knowledge diffusion, favour implementation of the principle of 3R (Reduce, Reuse, Recycle) of the concept of sustainable development. Reduction of use of natural resources and energy, as well as waste (reduce) is a desired and rational activity within sustainable development. In the case of waste management these activities can consist in introduction of tools and solutions reducing the use of multi-material, large packaging, particularly these that do not perform usability role, but mainly marketing one, promoting reusable packaging and centres of their purchase. The latter, as well as organisation of the so-called centres of their reuse, lobbying for repeated use of resources (e.g. water for industrial purposes, devices recuperating heat), correspond to the second principle of the concept, i.e. reuse. Limited possibilities in the sphere of waste reduction and reuse bring implementation of activities in the sphere of the third principle, i.e. recycle. Its execution depends on skilful integration of selective collection of waste with its commercial reuse (Kronenberg \& Bergier, 2010).

Considering what has been said, companies providing public utilities services perform the role of the so-called promoters of relationships based on three principles of sustainable development (3R) in the system of relationships with entities representing the environment of suppliers of the stream of waste and commercial use for the purpose of acquisition of sustainable value in the form of balance between social and environmental well-being an the economic effect in long term perspective. Its success also depends on skilful knowledge management in this eco-system that builds awareness, prosumer attitudes and satisfaction from involvement. It also results from competent engagement of IT technology.

\section{Eco-system of Sustainable Relationships of the Enterprise Providing Collection and Waste Management Services}

Amending the Law on keeping cleanness and order in municipality (Dziennik Ustaw [Official Journal of Law] of 2013), changed the previous way of municipal waste management and the role of public utilities enterprise in eco-system of knowledge-based relationships that serve sustainable development. Ecological result is obtained thanks to reducing the time of application of solutions promoting the use of renewable sources of energy, implementation of selective waste collection, reducing the amount of waste dumped in unlisted landfills, formalising composting of biodegradable waste and the chance for development of areas for recycled resources, including enterprises producing fuels from municipal waste. Considering the content of the Law, public utilities enterprises, particularly of RIPOK type (Regionalna Instalacja Przetwarzania Odpadów Komunalnych oraz Odpadów Zielonych [Regional Installation of Municipal Waste and Green Waste Processing] is gaining the role of creator of the platform of knowledge diffusion that develops awareness, and activates the stakeholders in the process of sustainable values formation.

The studied enterprise - MASTER - Odpady i Energia Sp. z o.o. in Tychy provides complex services in the sphere of collection and management of municipal waste. The company is specialised in waste collection and disposal, selective collection of waste and renewable energy production. Closing the chain of waste management, from production through

${ }^{2}$ Compatibility of intelligent development and sustainable development found their reflection in the works of European Commission that indicated three priorities in the document Europe 2020. Strategy for intelligent and sustainable development favouring social inclusion:

1) intelligent development: development of knowledge and innovation based economy;

2) sustainable development: support for economy that effectively uses resources, that is more ecologically friendly and more competitive;

3) development favouring social inclusion: support for economy of high level of employment that ensures social and territorial coherence. (Europe 2020. Strategy for intelligent and sustainable development favouring social inclusion, 2010)

${ }^{3}$ More on the subject of formation of systemic values in: Żabiński, 2012 
reduction of the amount of produced waste, returning the products of waste management to economy, and finally disposal of food waste that forms a specific type of Eco-system for creation of sustainable values is one of assumptions of the company functioning. This is also because the installation MASTER-ODPADY I ENERGIA Sp. z o.o. in Tychy was given the status of INSTALACJA REGIONALNA MBP [REGIONAL INSTALLATION MBP], i.e. the installation for mechanical and biological processing of mixed municipal waste (MBP) for Region IV. This means processing municipal waste that comes from municipalities located in the southern part of Śląskie voivodeship ${ }^{4}$ (RIPOK). Three major groups of entities are distinguished as participants in this network of relationships in the Eco-system of sustainable value creation.

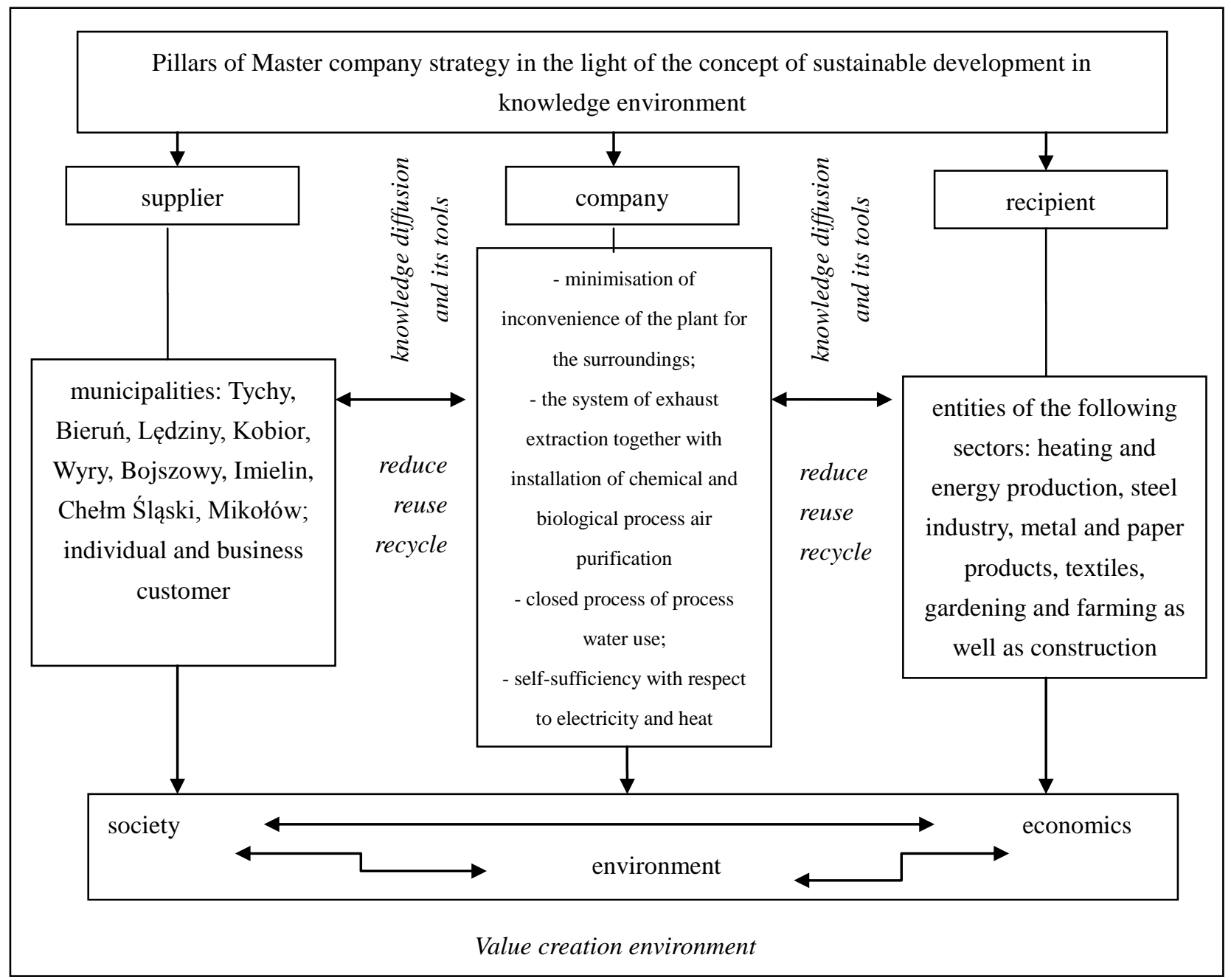

Figure 1. Pillars of Master company strategy in the light of the concept of sustainable development, in knowledge environment

Source: own case study

The company is the implementer of the concept of integral marketing with the elements of prosumer approach to customer. It is a coordinator and creator of value stream for which individual and business customer is the initiator and recipient. This fact proves systemic concept of company activity according to principles of $3 \mathrm{R}$ concept of sustainable

\footnotetext{
${ }^{4}$ With the RESOLUTION NO V/6/21/2015 of Sejmik Województwa Śląskiego [Regional Council of Śląskie Voivodeship] of 16th March 2015 on the amendment to the resolution No IV/25/2/2012 of Sejmik Województwa Śląskiego [Regional Council of Ślaskie Voivodeship] of 24th August 2012 in implementation of „Waste management plan for Śląskie voivodeship 2014" the following changes are introduced: in table „List of installations for mechanical and biological processing of mixed municipal waste (MBP)" for Region IV: Installation MASTER-ODPADY I ENERGIA SP. Z O.O. in TYCHY is given the status of REGIONAL INSTALLATION MBP.
} 
development (table 2).

Table 2. Methods of implementation of the concept of 3R sustainable development in studied company

\begin{tabular}{|c|c|c|}
\hline reduce & reuse & recycle \\
\hline $\begin{array}{c}1 / \text { use of the installation of } \\
\text { mechanical and biological waste } \\
\text { processing that allows to obtain: } \\
\text { secondary raw materials (paper, } \\
\text { cardboard, glass, plastics, metals) } \\
\text { for recycling, } \\
\text { components for production of } \\
\text { alternative RDF fuel, } \\
\text { biogas from which electricity and } \\
\text { heat are produced), } \\
\text { stabiliser (compost that dose not } \\
\text { meet fertiliser requirements), } \\
\text { soil improver obtained from } \\
\text { composting of green waste. }\end{array}$ & $\begin{array}{l}\text { 1/ cooperation with prospective } \\
\text { construction sector with respect to } \\
\text { the possibility to refine construction } \\
\text { waste and generate high-quality } \\
\text { aggregate, } \\
\text { 2/ use of by-products obtained in } \\
\text { the process of air purification in the } \\
\text { form of ammonium sulphate that } \\
\text { might be used as fertiliser in } \\
\text { agriculture, } \\
\text { 3/ organising and promoting the } \\
\text { so-called reuse Centres, } \\
\text { 4/ promoting and supporting the } \\
\text { network of repairs and reuse, } \\
\text { particularly of bulky waste, } \\
\text { 5/ solar installations for production } \\
\text { of warm usable water, } \\
\text { 6/ filling in the empty spaces that } \\
\text { occurred after coal mining in } \\
\text { protective pillars. }\end{array}$ & $\begin{array}{c}\text { 1/selective collection of waste with separation } \\
\text { of ash, } \\
\text { 2/ organisation of Centres of Selective } \\
\text { PSZOllection of Municipal Waste (the so-called } \\
\text { 3/ collection of dangerous waste, } \\
\text { 4/ municipal waste management, } \\
\text { 5/ production of alternative fuels, production } \\
\text { of electricity and heat from landfill biogas } \\
\text { OZE within installation of landfill degassing } \\
\text { and installation of biological waste processing } \\
\text { (fermentation) in the Plant. } \\
\text { 6/ application of depolymerisation processes } \\
\text { that serve processing waste from plastics, the } \\
\text { result of which is a liquid fuel component, } \\
\text { paraffin oil, } \\
\text { 7/ document disposal services with acquisition } \\
\text { of recycled paper waste, } \\
\text { 8/ gasification of residual waste from plants } \\
\text { and sludge from Regionalne Centrum } \\
\text { Gospodarki Wodnościekowej [Regional } \\
\text { Centre of Water and Waste Water } \\
\text { Management] }\end{array}$ \\
\hline
\end{tabular}

Source: Own case study

Effectiveness of the company operation is expressed in the recovery and production rate at the assumption of full working efficiency of the Plant ${ }^{5}$.

\section{Tools of Implementation of the Concept of Sustainable Development through Knowledge Management on Selected Example}

The studied company providing public utilities services establishes the community of sustainable values on the level of knowledge exchange in three subsystems of relationships with stakeholders (fig. 2).

\footnotetext{
${ }^{5}$ In the case of Master company they are the following annual amounts:

- 10 thousand tonnes of recyclable materials,

- 10 thousand tonnes of energy producing materials for production of alternative fuels RDF,

- 10 thousand tonnes of construction waste,

and production of:

- biogas production in the amount of $1980000 \mathrm{Nm}^{3} /$ year,

- electricity in the amount of $4000 \mathrm{MWh} /$ year,

- heat in the amount of $14000 \mathrm{GJ} /$ year,

- 15 thousand tonnes of stabiliser for re-cultivation,

- 2 thousand tonnes of compost from green waste.
} 


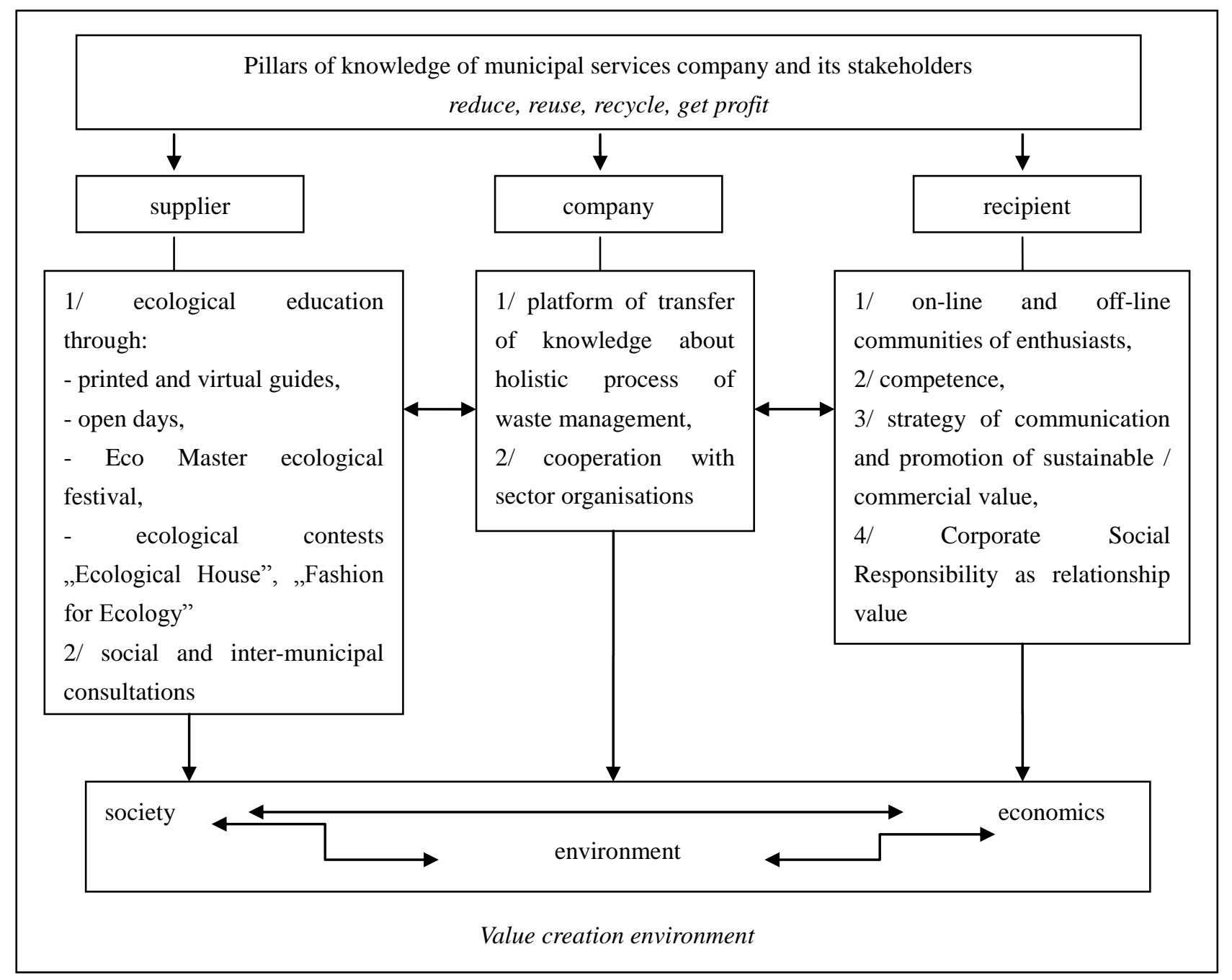

Figure 2. Knowledge pillars of public utilities company and its stakeholders

Source: own case study

Subsystem of relationships with supplier is made of targeted educational actions, and social as well as inter-municipal consultations. The company activates local community to undertake projects of strategic dimension, i.e. establishment of aware pro-ecological behaviours. The major assumption of ecological education in this case is to show the inhabitants of the city and also neighbouring communes of Śląskie voivodeship how important the idea of recycling is and how it can be applied in everyday life thorough appropriate waste management with special focus on selective collection of raw material waste, electrical and electronic equipment and also batteries.

The company's task is to create the platform of knowledge about holistic process of waste management on all levels from local to national and European Union in sub-spheres of all groups of stakeholders from municipal waste suppliers to recipients of commercial products. Suggested tools include platforms of ecological knowledge communities, seminars, conferences, social consultations with co-participation of such sector organisations as Krajowa Izba Gospodarki Odpadami [National Chamber of Waste Management] (KIGO), Polska Izba Gospodarki Odpadami [Polish Chamber of Waste Management] (PIGO), Stowarzyszenie Polskich Przedsiębiorców Gospodarki Odpadami [Association of Polish Waste Management Entrepreneurs], Ogólnopolska Izba Gospodarcza Recyklingu [All-Poland Economic Chamber of Recycling] and Polska Izba Ekologii [Polish Ecology Chamber].

The subsystem of knowledge based relationships with commercial recipient should be based on the so-called on-line and off-line communities of enthusiasts, competence centres with qualified access to knowledge with respect to the value brought to the system, strategies of communication and commercial promotion of sustainable value and activation of relationships on the basis of co-implementation of Corporate Social Responsibility. 


\section{IT Solutions for Sustainable Eco-system of Public Utility Services}

Entities of utilities sector (utility services) aim at achievement of better consolidation and control of key corporate processes including knowledge diffusion and increase in transparency of flow and centralisation of purchase and investments by means of systemic IT solutions. Tendencies that are conducive to investments of this sector in IT include:

- Information Technology and Operational Technology convergence,

- the need to streamline and standardise communication between the participants in utilities market,

- liberalisation of energy market,

- occurrence of multi-product, systemic offers, ,

- increase in the significance of RES (renewable energy sources).

According to the entities of IT sector, the needs of the sector of utilities services concern smart metering / smart grids (intelligent measuring), information hubs, systems for dynamic balancing of MDM network (Meter Data Management), solutions for SMO (Smart Measurements Operators), HAN (Home Area Network), smart management of waste streams and energy at home (Computerworld TOP200, 2007-2015). Oracle Poland, Capgemini Poland, IT.expert, SAP Poland, Unisoft were the largest suppliers of such IT solutions and services for the sector of utilities between 2010 and 2014.

Generally, mobile Internet, smart things (smart waste separators), automation of knowledge-based work, cloud computing for big data, advanced robotics, self-propelled vehicles in landfills, the next generation of genomics, 3D printing, advanced methods of exploitation of raw material deposits and advanced technologies of municipal waste processing into energy are technologies that, according to experts of McKinsey Global Institute will perform an enormous role in social and economic life until 2025. All these technologies are associated with the necessity to provide the possibility to process large amount of data which is the task for companies offering IT solutions and services (Farley, Walker, Harris, 2012).

\section{Conclusions}

Operators providing public utilities services perform a significant role in implementation of the concept of sustainable development in local and supra-local perspective. They constitute a specific type of catalyser of relationships based on knowledge transfer in three subsystems of holistic model of sustainable development: company subsystem, supplier of waste streams and recipient of commercial value. An enterprise is an implementer of the integral concept of knowledge-based activity while promoting the idea of sustainable development through closing the chain of waste management and obtaining profit. The concept of sustainable development through management of knowledge of the eco-system stakeholders, integrated by companies of utility services, are favoured by IT solutions in the sphere of improvement of the processes of waste collection and processing as well as formation of platforms of knowledge diffusion. The final conclusion is that, the model of sustainable development through knowledge management in researched firm and partners is multi-subject, multifunctional and multi-tool.

\section{References}

Alvarenga, N. R. C. D. (2008). Gestão do conhecimento em organizações: proposta de mapeamento conceitual integrativo [Knowledge management in organizations: an integrative conceptual mapping proposition]. São Paulo: Editora Saraiva (Saraiva Publishers)

Cash, D. W., Clark, W. C., Alcock, F., Dickson, N. M., Eckley, N., Guston, D. H., Jager, J., \& Mitchell, R. B. (2003). Knowledge systems for sustainable development. Science and Technology for Sustainable Development Special Feature. http://dx.doi.org/10.1073/pnas.1231332100

Choo, C. W. (1998). The Knowing Organization: How Organizations Use Information for Construct Meaning, Create Knowledge and Make Decisions. New York: Oxford Press.

Computerworld TOP200, Polski Rynek Informatyczny i Telekomunikacyjny 2007-2014 [Polish Information and Telecommunication Market, 2007-2014.

Creech, H., \& Willard, T. (2001). Strategic Intentions: Managing knowledge networks for sustainable development. International Institute for Sustainable Development Canada. https://www.iisd.org/pdf/2001/networks_strategic_intentions.pdf

Dziennik Ustaw [Official Journal of Law] 2013, p.1399

Europe 2020. Strategy for intelligent and sustainable development favouring social inclusion. Commission Communication, Brussels. 
Farley, N., Walker, D., \& Harris, R. (2012). Technological, Managerial and Organizational Core Competencies: Dynamic Innovation and Sustainable Development. Business Science, 653-674.

Gerwin, M. (2008). Plan zrównoważonego rozwoju dla Polski: lokalne inicjatywy rozwojowe, Sustainable Development Plan for Poland: Local Developmental Initiatives. http://www.sopockainicjatywa.org/earth/pdf/LIR-new.pdf

Konstytucja Rzeczypospolitej Polskiej. Constitution of Poland. http://trybunal.gov.pl/?id=106\#_Rozdzial01

Kozłowski, S. (2005). Przyszłość ekorozwoju, [The Future of Eco-Development], Lublin, KUL

Kristjanson, P., Reid, R. S., Dickson, N., Clark, W. C., Romney, D., Ranjitha, P. R., MacMillan, S., \& Grace, D. (2009). Linking international agricultural research knowledge with action for sustainable development. Sustainability Science. http://dx.doi.org/10.1073/pnas.0807414106

Kronenberg, J., \& Bergier, T. (2010). (ed.). Wyzwania zrównoważonego rozwoju w Polsce, Challenges of sustainable development in Poland, Fundacja Sendzimira, Kraków, 294-296.

Nonaka, I., \& Konno, N. (1998). The concept of „ba': building a foundation for knowledge creation, California Management Review, 40 (3) 40-54. http://dx.doi.org/10.2307/41165942

Perry, C. (2001). Case Research in Marketing. The Marketing Review, 1(305). http://dx.doi.org/10.1362/1469347002530790

Roblek, V., Meško, M., Pejić, B. M., \& Bertoncelj, A. (2014). Impact of knowledge management on sustainable development in the innovative economy.

http://www.academia.edu/5060916/Impact_of_knowledge_management_on_sustainable_development_in_the_inn ovative_economy

Stappen, R. (2006) Raport Brundtland, Nowy Jork 2006

Uchwała NR V/6/21/2015 Sejmiku Województwa Śląskiego, Regional Council of Ślaskie Voivodeship. z dnia 16 marca $2015 \mathrm{r}$.

Ustawa z dnia 27 kwietnia 2001 r. Prawo ochrony środowiska: Dz. U. z 2001 r. Nr 62, p. 627 [Act of 27th April 2001 Law of environment protection] Dz. U. [Official Journal of Law] of 2001. No 62, section. 627

Von, K. G., Ichijo, K., \& Nonaka, I. O. (2000). Enabling knowledge creation: how to unlock the mystery of tacit knowledge and release the power of innovation, Oxford; New York, Oxford University Press.

Żabińska, T., \& Żabiński, L. (2007). (ed.). Zarządzanie marketingowe. Koncepcje marketingu a praktyki zarządzania. Aspekty teoretyczne i badawcze. Marketing Management. Marketing Concepts and Management Practices. Theoretical and Research Aspects. AE Katowice, 83.

Żabiński, L. (2012). (ed.). Marketing produktów systemowych, Marketing of Systemic products. PWE, Warszawa

\section{(cc) $\mathrm{BY}$}

This work is licensed under a Creative Commons Attribution 3.0 License. 


\title{
Discourse, Strategy, and Practice of Urban Resilience against Flooding
}

\author{
Yu-Shou Su ${ }^{1 \& 2}$ \\ ${ }^{1}$ Inspector, National Development Council, Taiwan (R.O.C.) \\ ${ }^{2}$ Fellow, Penn Institute for Urban Research (Penn IUR), University of Pennsylvania, United States \\ Correspondence: Yu-Shou Su, National Development Council, 3F., No. 3 Baoqing Road, Taipei City 10020, Taiwan \\ (R.O.C.). Tel: 886-2-2316-5816.
}

\author{
Received: January 13, 2016 Accepted: January 28, 2016 Online Published: February 1, 2016 \\ doi:10.11114/bms.v2i1.1348 URL: http://dx.doi.org/10.11114/bms.v2i1.1348
}

\begin{abstract}
Resilience discourse is shifting the very meaning of "resilience" from "bouncing back" to "bouncing forward" in the twenty-first century. International policies have provoked cities to play a proactive role in applying land-use and environmental planning strategies for disaster resilience. Strategies of urban flood resilience include prevention, accommodation, fortification, protection, retreat, and green infrastructure. In general, four models of resilience against flooding are primarily adopted: the structure model, the non-structure model, the land-use and environmental planning model, and the retreat planning model. Results indicate that planning more space for the river, wetland planning, polder and retention areas, and permeable surface design do matter in reducing flood risks. Additionally, urban growth management, directing developments and populations away from floodplains, could reduce flood risks and damages. Finally, in retreat model, urban resilience stresses retreat and evacuation to reduce flood damages. Retreat strategies and alternatives, such as property buyouts, relocations, new towns for accommodations, and land swaps for less risky areas, could be applied in helping to achieve urban flood resilience.
\end{abstract}

Keywords: urban resilience, resilience planning, flood prevention, sustainability

\section{Introduction}

The number of climate-related disasters, floods and storms, has soared significantly around the world since the 1980s. Urban resilience is gaining influence. Strengthening resilience helps to achieve sustainability. Diverse concepts of resilience, including equilibrium resilience, adaptive resilience, evolutionary resilience, and social-ecological resilience, were proposed in the past three decades. However, in the spatial planning field, urban resilience is still quite a new topic with lack of practice and implementation. Some questions remain uncertain. What is resilience planning? Can resilience be planned? How is resilience implemented? How is resilience measured? Additionally, literature reviews indicate the lack of articles regarding urban resilience and resilience planning. This article fills the gap regrading urban resilience planning. First, it analyzes the discourse, international policy, and institution to understand the context and content of urban resilience. Second, this article discusses major strategies of urban resilience planning. Third, it explains four models being used to encourage urban flood resilience, including the engineering/structure model, the non-engineering/non-structure model, the land-use and environmental planning model, and the retreat planning model. These four models of urban flood resilience are not independently adopted for policies. On the contrary, the combination of these four models helps to achieve urban resilience against flooding.

\section{Discourse, Policy, and Institution of Urban Resilience}

Resilience originally meant the ability of a system to return to its original condition after a disturbance, which was defined as engineering resilience or equilibrium resilience (Holling 1973). However, the resilience discourse is shifting from equilibrium resilience to adaptive, evolutionary, and social-ecological resilience. This results in shifting the very meaning of "resilience" from "bouncing back" to "bouncing forward" in the twenty-first century. In other words, engineering or equilibrium resilience, focusing on return time, recovery, and bouncing back, has shifted to evolutionary, adaptive, and social-ecological resilience, emphasizing bouncing forward and robust function with adaptive capacity and self-organization to disturbances. Adaptive resilience for "bouncing forward" has become a core value of resilience. The more adaptive, persistent, and transformable their system, the more resilient a city is. "Urban resilience is a city that is adjustable, adaptive, and flexible to evolve in the face of uncertainty or disasters. Enhanced resilience also allows 
better anticipation of disasters and better planning to reduce disaster losses" (The National Academy of Sciences 2012). Although diverse concepts of resilience were proposed after the 1970s, some questions in the planning field remain uncertain. What is resilience planning? Can resilience be planned? How is resilience implemented? How is resilience measured? Generally, resilience planning is still quite a new topic with lack of practice and implementation. In city planning, resilience was not an emphasis until the sustainable development movement and devastating natural disasters occurred in the twenty-first century. The concept of sustainability helps resilience planning, but sustainability and resilience are different. Sustainable development mainly focuses on equity and efficiency of resource use. However, resilience planning concentrates mostly on the adaptive strategies after disasters or preventive policies for disaster risk reduction. Although sustainability and resilience are different in meaning, scope, and practice, they have a relationship of integrative dependence. As Yuzva and Zimmermann (2012) stress "a sustainable city must be a resilient city". Riasi and Pourmiri (2016) studied the relationship between sustainability, urban resilience, and tourism industry and found that cities with strong plans for urban resilience are more successful in achieving sustainability. Many other studies also found a similar relationship between resilience and sustainability (Amiri Aghdaie et al. 2012; Fiskel 2006; Milman and Short 2008; Riasi and Amiri Aghdaie 2013; Riasi and Pourmiri 2015; Rosic et al. 2009). Therefore, strengthening urban resilience helps to achieve sustainability.

Regarding urban resilience, few books and articles have promoted resilience planning since 2000. For instance, Vale and Campanella (2005), The Resilient City, explain how modern cities recover from disasters, particularly after devastating earthquakes and city fires; Birch and Wachter (2006), Rebuilding Urban Places after Disaster, written after Hurricane Katrina, describes how to rebuild, prepare for disaster risk reduction, and make cities less vulnerable by different levels of government in partnership with the private sector and public will. Regarding journal articles in planning, the Journal of the American Planning Association (JAPA) from 1999 to 2009 has published only one article with urban resilience in the title: Campanella (2006) "Urban Resilience and the Recovery of New Orleans". This article argues that urban resilience involves much more than rebuilding. No article with a title pertaining to urban resilience and resilience planning of the Journal of Planning Education and Research (JPER) in 1995-2014. However, there are 10 articles with a title related to rebuilding, post-disaster planning, and natural hazard mitigation planning during the past twenty years, mostly published after 2005. In the JAPA, there are 6 articles with a title of natural disaster, rebuilding, resilience, or recovery. Therefore, after devastating Hurricane Katrina in 2005, there are more articles discussing urban resilience. For example, there are 2 out of 9 articles in the JAPA's Spring 2006 discussing urban resilience. A new journal focused on resilience was released in 2010, the International Journal of Disaster Resilience in the Built Environment (IJDRBE). The IJDRBE's Issue 1 of 2013: "Special Issue: Making Cities Resilient". More articles discuss rebuilding experiences and disaster risk reduction, mainly developing countries' case studies.

International policies regarding resilience can help to understand the concept of urban resilience planning. Notable is the United Nations International Strategy for Disaster Reduction (UNISDR). The UNISDR indicates that "a resilient city can be planned by a more proactive role in applying land-use planning in natural disasters and hazard mitigation". In general, there are three major international policies for urban resilience: 1. Framework for Action 2005-2015: Building the Resilience of Nations and Communities to Disasters (known as HFA) and the Post-2015 Framework for Disaster Risk Reduction (known as HFA2); 2. Sustainable Development Goals (SDGs): the eleventh goal is to make cities and human settlements inclusive, safe, resilient and sustainable; and 3. Intergovernmental Panel on Climate Change (IPCC) report on Climate Change 2014: Impacts, Adaptation, and Vulnerability. In sum, the HFA, SDGs, and IPCC have provoked cities to play a proactive role in applying land-use planning strategies in disaster risk reduction (see Table 1). Mitchell et al. (2014) argue that "integrating these three frameworks of HFA, SDGs, and IPCC will provide a unique opportunity to deliver a coherent strategy and implementation plan to reduce disaster risk". They also propose a global target of reducing 50\% of deaths and 20\% of economic losses from all disasters by 2030 (Mitchell et al. 2014). 
Table 1. International policies regarding urban resilience

\begin{tabular}{|c|c|c|}
\hline International policies & $\begin{array}{l}\text { Framework for Action } \\
\text { 2005-2015: Building the } \\
\text { Resilience of Nations and } \\
\text { Communities to Disasters } \\
(H F A)\end{array}$ & $\begin{array}{l}\text { United Nations' Sustainable Intergovernmental Panel on } \\
\text { Development Goals (SDGs) Climate Change (IPCC) }\end{array}$ \\
\hline Goals & $\begin{array}{l}2005 \\
\text { - Promote a strategic and } \\
\text { systematic approach to } \\
\text { reduce vulnerabilities and } \\
\text { risks to hazards } \\
\text {-Involve community-level } \\
\text { participation } \\
\text { - Target the most vulnerable } \\
\text { populations, } \\
\text { - Integrate climate change } \\
\text { adaptation, development } \\
\text { and disaster risk } \\
\text { reduction, } \\
\text { - Strengthen } \\
\text { capacity-building of } \\
\text { financing, risk assessment, } \\
\text { and preparedness }\end{array}$ & 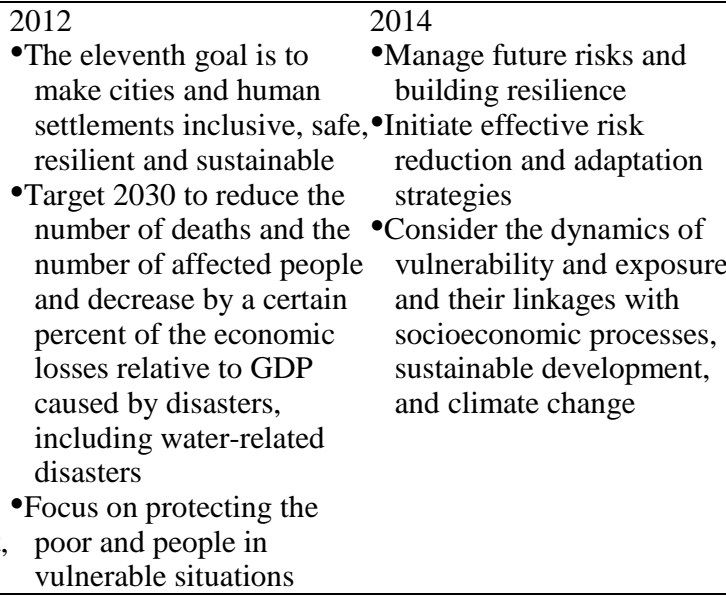 \\
\hline
\end{tabular}

The HFA puts emphasis on the importance of city planning to achieve resilience and reduce risks. The HFA's "Making Cities Resilient Campaign", launched in 2010, has provoked local governments to play a role in urban resilience. The HFA2 suggests that urban resilience focuses on community-level involvement, targeting the most vulnerable populations, integrating climate change adaptation, strengthening capacity-building of financing, risk assessment, and preparedness, and promoting political will and leadership. Additionally, the UNISDR recommends some steps to make cities resilient: 1. create and fund well-defined coordinated organizational structures; 2. prepare risk assessments, develop and enforce risk-compliant building codes and land-use planning tools; 3 . strengthen critical infrastructure and upgrade key facilities; 4. protect ecosystems and natural buffers; 5. test early-warning systems and emergency management capacities; 6. sponsor education and training programs on disaster risk reduction (UNISDR 2013). At the end of 2014, the United Nations released two reports: Post-2015 Framework for Disaster Risk Reduction: Zero Draft (known as Zero Draft) and Suggested Elements for the Post-2015 Framework for Disaster Risk Reduction. The two reports provide suggestions for local governments to implement a resilience plan, including: periodically estimate the probability of disaster risks to the population and to economic and fiscal assets; ensure that national and local plans prevent the creation of new risks, reduce existing risks and strengthen resilience; guide the public sector in addressing disaster risk; regulate and provide incentives for actions by households, communities, businesses and individuals; review existing financial and fiscal instruments; and stimulate the development of disaster risk management (United Nations 2014). In March 2015, the Third United Nations World Conference on Disaster Risk Reduction was held in Sendai, Japan. This conference stresses that disaster risk reduction inherently involves forward planning. Investments in disaster risk reduction and urban resilience can advance both sustainable development and climate action. This conference also stresses that help must be given the poorest and most vulnerable people and countries to manage disaster risk. The Implementation of the Sendai Framework for Disaster Risk Reduction over the next 15 years will require strong commitment and political leadership. Several targets are to be achieved in this framework: a reduction of disaster mortality, affected people, economic losses, and critical infrastructure; an increase in the number of countries with national and local disaster risk reduction strategies by 2020; enhanced international cooperation; and increased access to multi-hazard early warning systems and disaster risk information and assessments (UNISDR 2015).

The SDGs' eleventh goal is to make cities and human settlements inclusive, safe, resilient and sustainable. This goal is aimed to significantly reduce deaths, affected people, and economic losses caused by flood-related disasters by 2030 . The goal concentrates on protecting the poor and people in vulnerable situations. Additionally, this goal aims to increase the number of cities and human settlements adopting and implementing integrated policies towards resilience to disasters (United Nations 2013). The IPCC's report on Climate Change 2014: Impacts, Adaptation, and Vulnerability considers how the impact and risk related to climate change can be reduced through adaptation and mitigation. Effective risk reduction and adaptation strategies must consider the dynamics of vulnerability and exposure. This report indicates that some low-lying developing countries and small island states are expected to face very severe impacts. These low-lying areas must take actions to address risks and impacts.

In addition to international policies, there are international institutions promoting urban resilience: the United Nations' International Strategy for Disaster Reduction (UNISDR), the World Bank's Global Facility for Disaster Reduction and 
Recovery (GFDRR), the OECD's Risk Management Division under the Directorate for Public Governance and Territorial Development, the Centre for Research on the Epidemiology of Disasters (CRED), the European Flood Directive (FD), Global Disaster Alert and Coordination System (GDACS), Asian Disaster Reduction Center (ADRC), and Asian Disaster Preparedness Center (ADPC), presented in Table 2. The World Bank mainly concentrates on the Asian nations' case studies. The World Bank (2013) report Building Urban Resilience: Principles, Tools, and Practice stresses that resilience planning needs to be the focus for cities. This report indicates that increasing population growth, urbanization and property development in urban vulnerable areas will be the major factor of increased damages and losses from disasters in the next decades. In East Asia, the urban population is expected to double between 1994 and 2025 (Jha and Brecht 2011). Most cities, with their concentration of assets, located along the coastline, in floodplains, or along seismic rifts, are vulnerable to disasters. Rapid and unplanned urbanization in combination with poorly constructed settlements and degraded ecosystems put more people and more assets in harm's way (The World Bank 2013). Building urban resilience relies on investment decisions that prioritize spending on activities that offer alternatives that perform well in different scenarios. The goal is also to formulate a strategy in which flexible and low-regret measures can be cost-effective even when risks are uncertain. Integrating risk-based approaches into urban governance and planning processes do matter in implementing policies of urban resilience. 
Table 2. International institutions and programs regarding urban resilience and disaster risk reduction

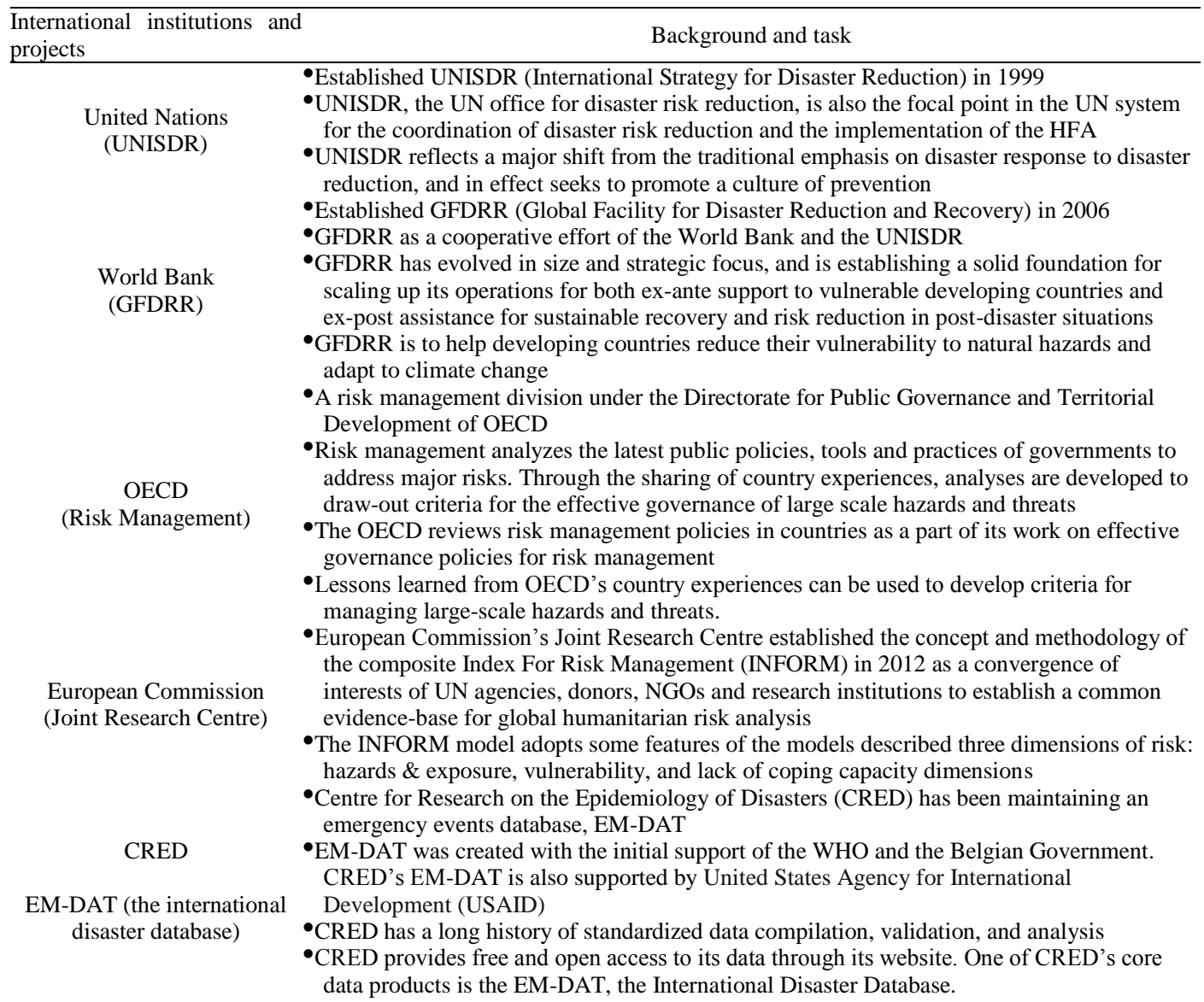

-The European Flood Directive (FD) was proposed by the European Commission in 2006 to reduce and manage the flood risk.

European Flood Directive ${ }^{\bullet}$ EU's $7^{\text {th }}$ Framework Program for Research and Technological Development (FP7) project: a

(FD) and EU's CORFU collaborative research on flood resilience in urban areas (CORFU), ongoing case studies project include: Barcelona, Beijing, Dhaka, Hamburg, Mumbai, Nice, Taipei, Incheon, and Seoul

- $\mathrm{CORFU}$ is to map the potential floods, vulnerability of the assets and humans at risk, and to take adequate and coordinated measures to reduce flood risk

$\bullet$ FRC has enabled responsible public authorities in eight cities in North West Europe to better cope with floods in urban areas

Flood Resilience City (FRC, • Ongoing eight case studies, including: Bradford, Brussels and Leuven, Dublin, Mainz, EU-funded project)

Nijmegen, Orleans, and Paris

•FRC is assessing the likelihood and consequences of current and future flooding, and the costs and benefits of different treatment options

- Global Disaster Alert and Coordination System (GDACS) is a cooperation framework under the United Nations umbrella Global Disaster Alert and
Coordination System $\quad$ GDACS includes disaster managers and disaster information systems worldwide and aims at (GDACS) filling the information and coordination gap in the first phase after major disasters

-GDACS provides real-time access to web - based disaster information systems and related coordination tools

-Promote a strategic and systematic approach to reduce vulnerabilities and risks to hazardsAsian Disaster Preparedness Center (ADPC) was established in Bangkok, Thailand, in 1986

Asian Disaster Preparedness

-ADPC has country offices in Bangladesh, Lao PDR and Myanmar. ADPC deploys disaster Center (ADPC) risk management (DRM) information and systems to reduce local, national and regional risk across Asia-Pacific.

-ADPC has a team of approximately hundred experts from 19 countries. ADPC creates a department of Resilient Cities and Urban Risk Management to assists cities and communities in managing and mitigating urban disaster risks.

- Asian Disaster Reduction Center (ADRC) was established in Kobe, Hyogo prefecture, in 1998 , in response to the 1995 Kobe earthquake.

Asian Disaster Reduction $\quad$ ADRC is to promote international cooperation and collaboration for the reduction of natural Center (ADRC) disasters in the Asian region. ADRC has 30 member countries and works to enhance disaster resilience. ADRC also addresses this issue from a global perspective in cooperation with a variety of United Nations' agencies including UNISDR. 
In Europe, two projects regarding urban flood resilience are underway: the EU's Collaborative Research on Flood Resilience in Urban Areas (CORFU) and Flood Resilience City (FRC). The CORFU project aims to map the potential floods, vulnerability of the assets and humans at risk, and to take adequate and coordinated measures to reduce flood risk. CORFU has ongoing case studies in Asia and Europe, including in Barcelona (Spain), Beijing (China), Dhaka (Bangladesh), Hamburg (Germany), Mumbai (India), Nice (France), Taipei (Taiwan), Incheon (South Korea), and Seoul (South Korea). The FRC project is to assess the likelihood and consequences of current and future flooding, and the costs and benefits of different treatment options. There are eight ongoing case studies in Europe: Bradford (UK), Brussels and Leuven (Belgium), Dublin (Ireland), Mainz (Germany), Nijmegen (Netherlands), Orleans (France), Paris (France). In Asia, there are two disaster reduction centers, the Asian Disaster Preparedness Center (ADPC) established in Bangkok in 1986, and the Asian Disaster Reduction Center (ADRC), which was established in Kobe in response to the 1995 Kobe earthquake in order to promote international cooperation and collaboration for disaster risk reduction among 30 Asian countries. These international institutions have promoted the research and policy implementation of urban resilience in the world.

\section{Strategies of Urban Resilience Planning against Flooding}

The goal of urban resilience planning is to reduce risks through planning. Generally, two types of strategy are: traditional engineering strategy and land-use planning strategy. Deyle and Butler (2013) identify 3 strategies for urban resilience on coastal hazards reduction: protest, accommodate, and avoid/ retreat (see Table 3). The Association of Bay Area Governments (2013) also describes some tools for resilience planning, including: general plans and specific plans; zoning tools such as overlay districts, nonconforming use regulations, special use permits; buyouts and financial incentives for where to build or not build. Olshansky (2009) observes that acquisition of flood-prone properties and permanent conversion of those properties to open space has become a leading federal strategy for solving serious flood problems since the 1993 floods in the Midwest of the U.SA. Further, Burby et al. (2006) point out that resilience planning includes "preventive, protection, and emergency policies". They indicate a preventive policy to limit the exposure of new development; property protection policy to retrofit buildings; and emergency services policy to reduce damages (Burby et al. 2006). They emphasize that urban planners should play a key role in preventive policies to reduce the exposure to disasters. However, with these diverse strategies of prevention, protection, and retreat, the main problem is that local governments often put a low priority on taking action unless the higher government mandates it. Because of the pro-growth and pro-development of local governments, resilient planning to reduce disaster risk is often ignored. For instance, in the U.S.A., local governments are not likely to pursue such measures vigorously without being forced to do so through mandates imposed by state governments (Burby et al. 2006). However, some state governments incentivize municipal scenario planning processes for urban resilience. Take New York State for instance, the NYS 2100 Commission (2012) suggests that the state can incentivize municipal scenario planning processes for evaluating risk to human, environmental, and economic assets from coastal storms and sea-level rise. Hence, resilience policies also need a top-down method as well as mandates and support from higher levels of government. 
Table 3. The content and strategy of resilience planning

\begin{tabular}{|c|c|}
\hline Resilience planning & Content and strategy \\
\hline Core ideas & $\begin{array}{l}\text { - An alternative plan format, a policy plan, rather a conventional plan } \\
\text { - Risk-based land use planning, instead of traditional development ignoring the } \\
\text { hazard characteristics of land }\end{array}$ \\
\hline \multirow[t]{2}{*}{ Scope } & $\begin{array}{l}\text { A regional approach for resilience planning; Long-term regional resilience } \\
\text { strategies must be developed }\end{array}$ \\
\hline & $\begin{array}{l}\text {-Integrating risk-based land use planning approach into urban governance and } \\
\text { process }\end{array}$ \\
\hline Planning process & $\begin{array}{l}\text {-Scenario planning process: providing the information, selecting complementary } \\
\text { land use and hazard-mitigation measures, and formalizing a long-term adaptation } \\
\text { strategy to effectively manage impacts }\end{array}$ \\
\hline \multirow[t]{2}{*}{ Prevention strategy } & $\begin{array}{l}\text { Preventive policies and actions, such as conservation zoning, to limit the exposure } \\
\text { of new development to losses from hazards }\end{array}$ \\
\hline & •Elevate structures \\
\hline \multirow[t]{3}{*}{ Accommodation strategy } & •Erosion-based setback \\
\hline & $\bullet$ Room for the water \\
\hline & •Shore armoring; beach nourishment \\
\hline \multirow[t]{2}{*}{ Protection strategy } & $\begin{array}{l}\text { - Property protection policies and actions, such as building standards and assistance } \\
\text { to property to owners to retrofit buildings to increase their resilience to hazards } \\
\text { - Structural protection policies and actions such as flood control works to provide } \\
\text { area-wide protection from hazards }\end{array}$ \\
\hline & -Prohibit development plus transfer of development rights \\
\hline \multirow{3}{*}{ Retreat/avoid strategy } & -Prohibit development plus acquisition \\
\hline & $\begin{array}{l}\text {-Post-disaster down-zoning planning with a tool of transfer of development rights } \\
\text {-Post-disaster plus acquisition }\end{array}$ \\
\hline & $\begin{array}{l}\text {-Rolling easements, initiated by U.S.A.'s EPA Climate Ready Estuaries Program, } \\
\text { which allow nature to take its course }\end{array}$ \\
\hline \multirow{2}{*}{$\begin{array}{l}\text { Green infrastructure } \\
\text { strategy }\end{array}$} & - A broader adoption of green infrastructure can minimize local problems with \\
\hline & $\begin{array}{l}\text {-Acquisition of flood-prone properties and permanent conversion of those } \\
\text { properties to open space. }\end{array}$ \\
\hline
\end{tabular}

In addition to resilience planning policies with cooperation among different levels of governments, a regional approach and integration is needed for urban resilience. Different cases show the importance. In New Orleans' experience, Birch and Wachter (2006) argue for a multidisciplinary approach for rebuilding after Hurricane Katrina. They point out that "the absence of an integrated approach has resulted in the pattern of ever increasing disasters and the need for cooperation across multiple levels of government". The Association of Bay Area Governments (ABAG 2013) also observes that there is no regional coordinating body currently in operation to facilitate decision-making in the aftermath of a major disaster. The ABAG indicates that "regional governance structures for coordination are well-established for disaster response". Hence, the ABAG created the Regional Resilience Initiative to build resilience through collaborative planning and jurisdictional collaboration (Association of Bay Area Governments 2013). In New York's rebuilding after Hurricane Sandy, the Hurricane Sandy Rebuilding Task Force (2013) stressed "the long-term plan for rebuilding is ensuring a regionally coordinated resilient approach to infrastructure investment because natural disasters do not respect political boundaries". Thus, rebuilding plans cannot be limited by jurisdictional boundary. Klinenberg and Ovink (2013) note this in the project Rebuild by Design which encourages plans on the regional scale, rather than the municipal or state level because many of the risks related to extreme weather events require cooperating across political boundaries.

\section{Four Models of Urban Resilience against Flooding}

The number of climate-related disasters, floods and storms, has soared significantly around the world since the 1980s (UNISDR 2013). As Kunreuther and Michel-Kerjan (2009) indicate, the $21^{\text {st }}$ century has been termed as "at war with the weather". Floods become more frequent and severely damaging because of rapid urbanization and extreme weather conditions. In both developing and developed countries, urbanization is causing change to the natural environment and threatens urban resilience. The urban poor live in more environmentally vulnerable areas in the developing countries (The World Bank 2001; 2013; Sinh et al. 2012). Urbanization in the developed countries has brought higher vulnerability and damage from flooding. In general, several models and practices being used to encourage urban flood resilience are: the engineering/structure model, the non-engineering/non-structure model, the land-use and environmental planning model, and the retreat planning model.

\subsection{Engineering/Structure Model}

Most countries adopted the engineering/structure model to reduce flood risk during the past century. This includes building costly dikes, dams, storm-surge barriers and dunes. In the United States, flood risk reduction has been dominated by the engineering strategy since the Mississippi River flooded in 1927. The Flood Control Act of 1930 
supported national structural flood control works (Brody et al. 2007, 2009). It is estimated that the U.S. Army Corps of Engineers (USACE) has spent more than $\$ 100$ billion for structural projects since the 1940s (Stein et al. 2000). An annual average of approximately $\$ 2$ billion was spent on flood control structures. However, these costly structural flood control projects often bring a false sense of security and result in encouraging new developments in and around floodplains. Once a flood event exceeds the capacity of the structure, it causes significant damage and economic loss. For instance, after the Galveston Hurricane of 1900, the city of Galveston, Texas built a seawall, 3 miles long and 17 feet high in 1902 to resist storm surges up to 15 feet high. However, seawalls cannot guarantee safety from a future storm. In 2008 Hurricane Ike's storm surge and large waves came over the seawall in Galveston. Severe losses occurred. Approximately $75 \%$ of all homes in Galveston were damaged or destroyed. Another example was the Great Mississippi Flood of 1927 where the flood proved that levee-dependence was an incontrovertibly failure. Prior to the flood, the Mississippi River Commission held the position that levees were the appropriate strategies for preventing floods. Powers (2006) describes that the 1927 flood altered the underlying theory regarding humanity's relationship with nature from one of domination to one of accommodation. Additionally, the Great Flood of 1993 tore through more than a thousand levees, causing almost $\$ 20$ billion of damage. In general, the average annual flood damage in the United States was estimated to have climbed steadily to $\$ 4$ billion (Stein et al. 2000). The USACE's annual \$2 billion investment on flood control structures can not reduce the increased annual flood damage of $\$ 4$ billion. In other words, although nationwide structural projects for controlling water were completed in the United States, urban flood resilience has not yet been achieved.

A similar situation occurred in the Netherlands, a nation with $65 \%$ of GDP produced below sea level. The well-known flood protection system, 53 dike rings, along the main rivers and coastal areas is the highest standard of flood protection facilities in the world. For example, Randstad, the economic heart of the Netherlands, is designed to resist a storm that is estimated to occur once in every 10,000 years (a probability of $0.01 \%$ annually). However, Wiering and Immink (2005) argue that the engineering strategy to reduce flood risk creates a "flood control paradox". The paradox is that strengthening dikes encourages more intensive land use. After a flood, dikes will be strengthened again. Then, higher density of land development occurs. Another flood will occur, and damages will be much more serious. This "flood control paradox" actually is a vicious cycle, and the measures to reinforce the dikes do not take away the cause of the problem, but create new risks (Wiering and Immink 2005). The Netherlands' dike ring protection structures were built with the highest standard after the devastating flood of 1953. However, severe floods still devastate Netherlands, such as the floods of 1993 and 1995. This explains why the highest level of flood protection system in the Netherlands can not guarantee absolute safety (Kolen et al. 2010).

In the United Kingdom, engineering structures to reduce flood risks are subsidized by central government, and continue to be the primary flood mitigation strategy (Penning-Rowsell and Handmer 1988). The costly facilities and repeated floods have made governments rethink the urban flood resilience policy. Studies indicate that "more money for flood defense would not be a permanent solution in the United Kingdom" (Howe and White 2010). The costly engineering structures can not guarantee safety or reduce flood damages efficiently and effectively. For instance, many flooding problems continue to threaten London after the completion of the Thames Barrier in 1982, the world's largest movable flood barriers. According to the Great London Authority (2002), the Thames tidal floodplain would have a $0.1 \%$ annual risk of flooding (a probability of $0.1 \%$ annually, or a flood in every 1,000 years), which amounts to a flood risk to property at a value of approximately $\$ 120$ billion. After numerous flood defense facilities in the U.K., floods occur in different locations, shifting the flood waters downstream (Howe and White 2010). Hence, flooding does not stop, but changes locations. In addition, the damage is worse when the defenses are eventually breached.

\subsection{Non-engineering/non-structure Model}

There are two types of non-structural model for urban flood resilience: the financial strategy and the planning strategy. The financial strategy includes rental incentives and insurance incentives. An example in Asia is Mumbai's rent control policy resulting in the lack of proper housing maintenance and severe damages from flooding. Stecko and Barber (2007) indicate that "many apartment buildings are subject to rent control which prohibits landlords from increasing rents in Mumbai. The rent control has constrained the willingness and ability of landlords to maintain rental accommodations, leading to inadequate housing". More and more buildings are dilapidated and crumbling due to the lack of proper maintenance (Stecko and Barber 2007). When a natural disaster occurs, the damage is severe. Thus, providing a financial incentive for landlords to increase rental in Mumbai would improve building maintenance and strengthen urban flood resilience. The financial incentive could also allow landlords to spend part of rent income for purchasing flood insurance.

Another financial strategy is flood insurance. Among flood insurance programs, the National Flood Insurance Program (NFIP) is most widely implemented in the United States and has been adopted by other countries. The NFIP was established in 1968 under the Federal Emergency Management Agency (FEMA) as an attempt to reduce flood losses. 
The NFIP provides insurance to those living in vulnerable areas as long as local jurisdictions adopt some minimum level of protection. FEMA creates the community's flood map and the flood insurance rate map (FIRM) to evaluate potential flood risk. In addition, FEMA's community rating system (CRS), adopted in the early 1990's, encourages communities to go beyond the NFIP's minimum standards for floodplain management by providing discounts of up to $45 \%$ on flood insurance premiums for residents of participating communities. However, there are some problems with NFIP, including increasing debt, out-of-date information on flood maps, and the encouragement of new developments in floodplains. Huber (2012) states that "The NFIP insures approximately 5.6 million American homeowners and has \$1 trillion in assets. The premiums collected have not been sufficient to cover losses, resulting in a current debt to the United States. Treasury of more than $\$ 18$ billion”. He suggests adjusting premiums, improving flood mitigation measures, and preparing for the catastrophic risk of events like Hurricane Katrina (Huber 2012). In addition, out-of-date information on flood maps from FEMA affects which homeowners should purchase flood insurance. After Hurricane Sandy devastated New York City in 2012, New York City's report, A Stronger, More Resilient New York (2013), indicates that more than 50\% of all buildings in the area flooded by Hurricane Sandy were outside of FEMA's 100-year floodplain map created in 1983. Another criticism is that the effectiveness of the NFIP encouraged floodplain development and generated repetitive losses with high financial costs (Brody et al. 2009). Discounting insurance premiums by the CRS system makes it less expensive for people to live in a 100-year floodplain, resulting in development in the most vulnerable areas to flooding (Brody et al. 2007). Furthermore, the lack of public awareness of floods remains. In the case of Hurricane Sandy, less than 50 percent of residential buildings in the pre-Sandy 100-year floodplain had flood insurance (The City of New York 2013). Therefore, the effort of flood risk awareness and communication needs to be more emphasized. Non-engineering strategy such as NFIP, provide financial incentives for homeowners to reduce their flood risks and losses. However, the incentive shouldn't increase the vulnerability of people living close to or in floodplains. Besides, flood insurance transfers risk and reduces homeowners' losses, but flooding risk doesn't disappear or ebb. Hence, another non-engineering strategy, land-use or environmental planning, becomes necessary to reduce vulnerability.

\subsection{Land-use and Environmental Planning Model}

In the last century, flood risk reduction around the world primarily relied on engineering structures. Historic floods indicate that flood resilience can not be achieved completely without land-use and environmental planning strategies. However, conventional land-use planning often ignores the hazard characteristics of the land. How to enhance risk-based land-use and environmental planning will play a role in reducing flood risk. Jha et al. (2013) emphasize "risk-based land-use planning", explaining that "integrating the risk-based land use planning approach into urban governance and process can help to make more sustainable ways to increase resilience" (Jha et al. 2013). However, flood risk reduction or water resource management is often not integrated with land-use planning. Woltjer and $\mathrm{Al}$ (2007) indicate "most water management decisions in the Netherlands are made without reference to spatial planning". They suggest the water impact assessment in municipal land use plans is a strategy for linking water management and spatial planning. The Luino et al. (2012) case study in Italy also indicates that "flood-prone areas have been conducted for years without considering land use" and that "urban development has not been controlled by careful land management that considers natural threats". Nonetheless, after the failure of the engineering strategy and the costly price of not integrating water management and land-use planning in reducing flood risks, the land-use and environmental planning strategy becomes more imminent. Hawkins (2013) stresses the importance of the connection between local comprehensive planning and disaster management. When members of organizations become more engaged in exchanging information among organizations within their planning network, they are more likely to have a favorable perception of the comprehensive plan in improving disaster resilience (Hawkins 2013).

In Europe, the European Commission's Flood Directive (2007) indicates that "flood risk management plans should focus on prevention, protection and preparedness, with a view to giving rivers more space". The European Commission's Water Framework Directive promotes a "river-basin approach" and "refers explicitly to interrelations between water management and land use". Flood management in Europe is shifting from building dikes (separating water from land use) to "space for the river" by land-use and environmental planning. Moreover, expanding the floodplain is a necessary planning strategy. Bye and Horner (1998) indicate "the defense flooding of a 1 in 100 year severity may only provide defense against floods of up to 1 in 30 year severity in the future" because of frequent extreme conditions and the global warming scenario. Woltjer and Al (2007) suggest "enlarging the floodplain area available to accommodate Rhine River waters during floods by converting land from urban and agricultural uses to a land use called water area." Hence, floodplains needs to be adjusted and expanded to accommodate water, and then reduce flood risk. Damages would also be decreased by allowing less development density in or adjacent to floodplains.

In addition to planning more space for the river to increase urban flood resilience, research indicates that wetland planning, polder and retention areas, and permeable surface design matter in reducing flood risks. The disappearance of 
wetlands and the increase in impervious surfaces due to rapid urbanization have increased the runoff and flood risk around the world. Research indicates that wetlands have a significant effect on flood risk reduction, and explains that basins with 5\% lake and wetland area may have $40 \%$ to $60 \%$ lower flood peaks than comparable basins without such hydrologic features (Novitski 1985). Brody et al. (2007) also studied the relationship of alteration of naturally occurring wetlands and flood damage through analyzing 383 flood events across 54 coastal counties in Florida from 1997 to 2001, and found that the alteration of naturally occurring wetlands significantly increases the property damage caused by floods. They also found that " $56 \%$ of all wetland alteration permits in research samples were located in 100 -year floodplains" (Brody et al. 2007). This means more wetlands were converted into new developments in floodplains in Florida. The disappearance of a large amount of wetlands as well as the occurrence of new developments in floodplains cause a higher vulnerability to floods. Brody and Gunn (2013) note that the percent of wetland loss matters in floods after examining environmental factors contributing to resilience along the Gulf of Mexico coast. Another example was Hurricane Katrina, as Dean (2006) indicates that the wetlands east of the Mississippi River lost $25 \%$ of their land area, but after Katrina, people finally understood the value of wetlands as a form of protection from hurricanes. Costanza et al. (2008) studied 34 major hurricanes in the U.S.A. since 1980, and found that "coastal wetlands reduce the damaging effects of hurricanes on coastal communities". They estimated that a loss of 1 hectare of wetland corresponded to an average $\$ 33,000$ increase in storm damage. Costanza et al. (2008) describe the coastal wetlands function as "horizontal levees for storm protection", and their restoration and preservation is an extremely cost-effective strategy (Costanza et al. 2008).

Polder systems and retention area planning also can reduce flood risks. Engkagul's Thailand case study indicates that planning for polder systems and retention areas would help reduce flood risk in larger areas (Engkagul 1993). Further, it is estimated that a 10-20\% increase of impervious surface within a drainage basin corresponds to doubling the runoff (Arnold and Gibbons 1996). The impermeable surface causes higher flood risk because of the increased runoff. Reducing the impervious surface would reduce flood risks. Therefore, land-use and environmental planning concentrating on wetland areas, water retention areas, and permeable surface design will provide a strategy for reducing flood risks. Woltjer and $\mathrm{Al}$ (2007) suggest a 10\% area in land use plans be for measures such as ponds and streams for emergency conveyance and storage of rain water, and permeable surfaces and grass-covered roofs to hold rain and allow soil infiltration.

Some case studies indicate that a significant flood risk comes from drainage flooding. Notable is the London case study. The Great London Authority (2002) evaluated London flood risks and identified three main types of flood risk: tidal, river, and drainage flooding. The result shows that "the most immediate and significant flood risk to London comes from drainage flooding" (Great London Authority 2002). Hence, integrating drainage systems with land-use planning provides another planning strategy to create robust flood resilience. In the United Kingdom, the Environment Agency (EA) is actively promoting the use of sustainable urban drainage systems (SUDS) to reduce levels of surface runoff. As Swan (2010) indicates "the SUDS approach, including green roofs, soak-aways, swales, infiltration basins and ponds, is intended to replace and/or augment an existing (combined or separate) drainage system within a developed catchment" (Swan 2010). The use of SUDS within a 'planning-based' approach, seeks to progressively impose green-field runoff restrictions to all new planning proposals (Swan 2010). Hence, SUDS can reduce the flood risk through retaining the flood volume temporarily and releasing it slowly at a lower flow-rate (Butler and Davies 2011). Howe and White (2010) also indicate that SUDS can help to attenuate water flow and prevent surface run-off, which can reduce flood risk. Swan (2010) stresses that urban planning has a key role to play in delivering more integrated and sustainable urban drainage systems in further urban regeneration over the next 50 years. He suggests that urban planning progressively retrofitting sustainable drainage to existing urban catchments needs to be more widely recognized. This will result in the reduction of flood risks and damages.

Another land-use and environmental planning policy, urban growth management, directing developments and populations away from floodplains, could reduce flood risks and damages. The United States case study in Florida indicates that urban growth management is an appropriate policy to reduce damages from hurricane flooding. Chapin et al. (2006) indicate that one of the main concerns of Florida's Growth Management Act in 1985 was to reduce damages from hurricane flooding. Since 1990, comprehensive plans require coastal communities to include policies that limit development in and direct populations away from coastal high hazard areas (CHHAs). Chapin et al. (2006) indicate "the more stringent policies for directing population concentrations away from CHHAs were associated with lower post-plan growth rates and growth densities". Hence, urban growth management to directing development away from floodplains and reducing its growth rate or density could provide a good strategy to reduce flood risks and vulnerability.

\subsection{Retreat and Evacuation Planning Model}

Some research of urban resilience stresses retreat and evacuation to reduce flood damage and its impact. A strategic retreat from hazardous coastal areas and alternatives, such as voluntary property buyouts, relocations, and land swaps 
for less risky areas should be explored to reduce flood risks and damages (Stein et al. 2000). Deyle and Butler (2013) also suggest a retreat model for flood risk reduction. Some strategies such as prohibiting development as well as the transfer of development rights (TDR), land acquisition, and down-zoning can be implemented. Additionally, an efficient evacuation plan is needed to reduce damages once severe floods do come. However, Kolen et al. (2010) indicate that one major issue is people's ability and willingness to evacuate. A plan needs to address the issue of people who do not or can not evacuate the area. In the U.S.A.'s case after Hurricane Katrina, it has been estimated that between 100,000 and 300,000 people did not or could not be evacuated from New Orleans. A large number of them were the city's poor populations, with 112,000 people not having access to personal vehicles (Wolshon 2006). Hence, helping the urban poor to evacuate demands the cooperation of government and non-profit organizations. Another factor is traffic capacity. Traffic management reduces the time required for evacuation. A Netherlands case study shows that "at least $20 \%$ of the people are still in the flooding area after 24 hours" (Kolen et al. 2010). Insufficient traffic capacity prevents the evacuation goal of 24 hours for coastal areas. In the U.S.A.'s experience after Hurricane Katrina, transportation infrastructure in New Orleans wasn't designed to accommodate the evacuation-level demand, and the traffic exit capacity is roughly $67 \%$, meaning that if the evacuation goes smoothly, the roads outside of New Orleans will only be able to take two-thirds of the people in 24 hours (Wolshon 2006). One-third of the people are in flooding areas. Hence, efficient traffic management becomes an important part of retreat and evacuation planning to reduce flood damage.

\section{Concluding Remarks}

The number of climate-related disasters, floods and storms, has soared significantly around the world since the 1980s. Urban resilience to flooding is gaining influence. Strengthening urban resilience also helps to achieve sustainability. Urban resilience planning concentrates mostly on the adaptive strategies. The more adaptive urban systems, the more resilient a city is. International policies regarding urban flood resilience are: United Nations' Post-2015 Framework for Disaster Risk Reduction (HFA), Sustainable Development Goals (SDGs), and Intergovernmental Panel on Climate Change (IPCC) report on Climate Change. These policies have provoked cities to play a proactive role in applying land-use and environmental planning strategies for disaster resilience. In general, there are four models around the world are primarily adopted for urban flood resilience: the engineering/structure model, the non-engineering/non-structure model, the land-use and environmental planning model, and the retreat planning model. In the engineering model, United States' costly structural projects for controlling water were completed mostly by the U.S. Army Corps of Engineers. However, flood control structures can not reduce the increased annual flood damage of $\$ 4$ billion in United States. In the Netherlands, the engineering model to reduce flood risk creates a flood control paradox, resulting in more intensive land use and higher vulnerability. In the non-engineering model, financial incentives and flood insurance are major strategies, moving housing away from vulnerable areas. In the land-use and environmental planning model, it has become more imminent after the failure of the engineering strategy and the costly price of not integrating water management and land-use planning in reducing flood risks. Planning more space for the river, wetland planning, polder and retention areas, and permeable surface design to increase urban flood resilience do matter in reducing flood risks. The United Kingdom is promoting sustainable urban drainage systems since a significant flood risk comes from drainage flooding. Additionally, the policy of urban growth management, directing developments and populations away from floodplains, could reduce flood risks and damages. In the retreat planning model, urban resilience stresses retreat and evacuation to reduce flood damage and its impact. These four models of urban flood resilience are not independently adopted. On the contrary, the combination of these four models helps to achieve urban resilience to flooding.

\section{Acknowledgments}

This study is part of Yu-Shou Su's Ph.D. Dissertation at University of Pennsylvania, United States. A special gratitude to Dr. Eugénie L. Birch, Chair of the Graduate Group in City and Regional Planning at University of Pennsylvania, for her professionalism, enthusiasm, and encouragement that have helped this research.

\section{References}

Aerts, J., Major, D. C., Bowman, M. J., Dircke, P., \& Marfai, M. A. (2009). Connecting Delta Cities. VU University Press, Amsterdam, Netherlands.

Amiri, A. S. F., Seidi, M., \& Riasi, A. (2012). Identifying the Barriers to Iran's Saffron Export by Using Porter's Diamond Model. International Journal of Marketing Studies, 4(5), 129-138.

Arnold, C. L., Jr., \& Gibbons, C. J. (1996). Impervious surface cover- age: The emergence of a key environmental indicator. Journal of the American Planning Association, 62(2), 243-258. http://dx.doi.org/10.1080/01944369608975688

Association of Bay Area Governments. (2013). Regional Resilience Initiative: Policy Agenda for Recovery 
Berke, P. R., Lyles, W., \& Smith, G. (2014). Impacts of Federal and State Hazard Mitigation Policies on Local Land Use Policy, Journal of Planning Education and Research 2014, 34(1) 60-76. http://dx.doi.org/10.1177/0739456X13517004

Birch, E. L., \& Wachter, S. M. (ed.). (2006). Rebuilding Urban Places after Disaster: Lessons from Hurricane Katrina. University of Pennsylvania Press.

Brody, S. D., \& Gunn, J. R. (2013). Examining Environmental Factors Contributing to Community Resilience along the Gulf of Mexico Coast. Disaster Resilience: Interdisciplinary Perspectives, Routledge, NY.

Brody, S. D., Kang, J. E., \& Bernhardt, S. (2009). Identifying factors influencing flood mitigation at the local level in Texas and Florida: the role of organizational capacity, Nat. Hazards., (2010) 52, 167-184

Brody, S. D., Zahran, S., Maghelal, P., Grover, H., \& Highfield, W. E. (2007). The Rising Costs of Floods- Examining the Impact of Planning and Development Decisions on Property Damage in Florida. Journal of the American Planning Association, 73(3), 330-345. http://dx.doi.org/10.1080/01944360708977981

Burby, R. J., Nelson, A. C., \& Sanchez, T. W. (2006). The Problems of Containment and the Promise of Planning. Rebuilding Urban Places after Disaster: Lessons from Hurricane Katrina. University of Pennsylvania Press.

Butler, D., \& Davies, J. W. (2011) Urban Drainage, 3rd Edition, Spon Press, London.

Bye, P., \& Horner, M. (1998). Easter 1998 Floods-Final Assessment by the Independent Review Team, Report to the Board of the Environment Agency, September.

Campanella, T. J. (2006). Urban Resilience and the Recovery of New Orleans. Journal of the American Planning Association, Spring 2006, 72(2). http://dx.doi.org/10.1080/01944360608976734

Chapin, T., Deyle, R., \& Baker, J. (2006). Assessing the Effectiveness of Comprehensive Plans in Mitigating Exposure of Florida Coastal Communities to Hurricane Flooding. Policy Brief, 23, Florida State University

City of New York. (2013). PlaNYC: A Stronger, More Resilient New York. City of New York.

Costanza, R., Pe'rez-Maqueo, O., Martinez, M. L., Sutton, P., Anderson, S. J., \& Mulder, K. (2008). The Value of Coastal Wetlands for Hurricane Protection. A Journal of the Human Environment, 37(4), 241-248. http://dx.doi.org/10.1579/0044-7447(2008)37[241:TVOCWF]2.0.CO;2

Dean, R. G. (2006). The Bridge: New Orleans and the Wetlands of Southern Louisiana, National Academy of Engineering.

Deyle, R. E., \& Butler, W. H. (2013). Resilience Planning in the Face of Uncertainty: Adapting to Climate Change Effects on Coastal Hazards. Disaster Resilience: Interdisciplinary Perspectives, Routledge, NY

Engkagul, S. (1993). Flooding Features in Bangkok and Vicinity: Geographical Approach, Geo Journal, 31(4), (December 1993), 335-338.

Environment Agency. (2001). Lessons learned Autumn 2000 floods.

Environment Agency. (2012). Managing flood risk through London and the Thames estuary, Thames Estuary 2100 (TE2100) Plan.

European Commission. (2007). Directive 2007/60/EC of the European Parliament and of the Council of 23 October 2007 on the assessment and management of flood risks, Official Journal of the European Union, Retrieved from http://ec.europa.eu/environment/water/flood_risk/key_docs.htm\#Directive

European Commission. (2012). Report from the Commission to the European Parliament and the Council on the Implementation of the Water Framework Directive (2000/60/EC) River Basin Management Plans.

Federal Emergency Management Agency. (2013). Hazus-MH: Flood User Manual. http://www.fema.gov/media-library-data/20130726-1820-25045-8814/hzmh2_1_fl_um.pdf

Fiksel, J. (2006). Sustainability and resilience: toward a systems approach. Sustainability: Science Practice and Policy, 2(2), 14-21.

Greater London Authority. (2002). Flooding in London A London Assembly Scrutiny Report November 2002.

Greater London Authority. (2009). London Regional Flood Risk Appraisal

Greater London Authority. (2012). London Strategic Flood Framework., Retrieved from http://www.london.gov.uk/sites/default/files/archives/london-prepared-London-Strategic-Flood-Framework-V2.pdf

Greater

London

Authority.

(2014).

Retrieved

from 
https://www.london.gov.uk/media/assembly-press-releases/2014/04/revive-rivers-to-reduce-flood-risk-in-london

Hawkins, C. V. (2013). Networks, Collaborative Planning, and Perceived Quality of Comprehensive Plans. Disaster Resilience: Interdisciplinary Perspectives, Routledge, NY

Howe, J., and White, I. (2010). Flooding- Are We Ignoring the Real Problem and Solution?, Regional Studies, 35:4, 368-370. http://dx.doi.org/10.1080/713693820

Huber, D. (2012). Fixing a Broken National Flood Insurance Program: Risk and Potential Reforms, Center for Climate and Energy Solutions (C2ES formerly the Pew Center on Global Climate Change), Retrieved from http://www.c2es.org/docUploads/flood-insurance-brief.pdf

Hurricane Sandy Rebuilding Task Force. (2013). Hurricane Sandy Rebuilding Strategy: Stronger Communities, A Resilient Region.

IPCC. (2007). "Climate Change 2007: Synthesis Report. Contribution of Working Groups I, II and III to the Fourth Assessment Report”, Retrieved from http://www.ipcc.ch/pdf/assessment-report/ar4/syr/ar4_syr.pdf.

IPCC. (2014). Summary for Policymakers. IPCC Working Group III Contribution to AR5.

Jha, A. K., Miner, T. W., \& Stanton-Geddes, Z. (2013). Building Urban Resilience: Principles, Tools, and Practice. The World Bank. http://dx.doi.org/10.1596/978-0-8213-8865-5

Joint Research Centre of the European Commission. (2015). Index for Risk Management (INFORM): Concept and Methodology. Luxembourg: Publications Office of the European Union

Klinenberg, E., \& Ovink, H. (2013). The Quest for the Best Designs for a Post-Sandy World, Retrieved from http://www.citylab.com/design/2013/09/quest-best-designs-post-sandy-world/6838/

Kolen, B., Holterman, S., Zuilekom, K., Friso, K., \& Helsloot, I. (2010). If things do go wrong- influence of road capacity on mass evacuation in the event of extreme flooding in The Netherlands, http://www.hkv.nl/site/hkv/upload/publication/

Kunreuther, H., \& Michel-Kerjan, E. O. (2009). At war with the weather: managing large-scale risks in a new era of catastrophes. Massachusetts Institute of Technology. http://dx.doi.org/10.7551/mitpress/9780262012829.001.0001

Kunreuther, H., \& Roth, R. (1998). Paying the Price: The Status and Role of Insurance Against Natural Disasters in the United States. Washington, DC: Joseph Henry Press.

Lang, R. E. (2006). Measuring Katrina’s Impacts on the Gulf Megapolitan Area. Rebuilding Urban Places After Disaster: Lessons from Hurricane Katrina. University of Pennsylvania Press.

London Assembly Environment Committee. (2014). Flood Risks in London: Summary of Findings. Retrieved from https://www.london.gov.uk/sites/default/files/14-04-07-Flood\%20risk\%20slide\%20pack\%20-\%20FINAL.pdf

Luino, F., Turconi, L. , Petrea, C., \& Nigrelli, G. (2009). Uncorrected land-use planning highlighted by flooding- the Alba case study (Piedmont, Italy), Natural Hazards and Earth System Sciences, 12, 2329-2346, 2012, www.nat-hazards-earth-syst-sci.net/12/2329/2012/

Milman, A., \& Short, A. (2008). Incorporating resilience into sustainability indicators: An example for the urban water sector. Global Environmental Change, 18(4), 758-767.

Mitchell, J. K. (1999). Crucibles of Hazard: Mega-cities and Disasters in Transition. United Nations University Press

Mitchell, T., Guha-Sapir, D., Hall, J., Lovell, E., Muir-Wood, R., Norris, A., Scott, L., \& Wallemacq, P. (2014). Setting, Measuring and Monitoring Targets for Reducing Disaster Risk: Recommendations for Post-2015 International Policy Frameworks. London: ODI.

Novitski, R. P. (1985). The effects of lakes and wetlands on flood flows and base flows in selected northern and eastern states. Proceedings of the Conference on Wetlands of the Chesapeake (pp. 143-154). Easton, MD: Environmental Law Institute.

OECD. (2014). OECD Reviews of Risk Management Policies: Seine Basin, Ile-de-France, 2014 Resilience to Major Floods

OECD. (2014). Water Governance in the Netherlands: Fit for the Future? OECD Studies on Water, OECD Publishing. http://dx.doi.org/10.1787/9789264102637-en

OECD. Poverty and Climate Change Reducing the Vulnerability of the Poor through Adaptation, http://www.oecd.org/env/cc/2502872.pdf

Olshansky, R. B. (2001). Land Use Planning for Seismic Safety: The Los Angeles County Experience, 1971-1994, 
Journal of the American Planning Association, 67(2). http://dx.doi.org/10.1080/01944360108976227

Olshansky, R. B. (2006). Longer View: Planning After Hurricane Katrina, Journal of the American Planning Association, 72(2). http://dx.doi.org/10.1080/01944360608976735

Olshansky, R. B. (2009). Planning for natural hazards. Local planning: contemporary principles and practice. ICMA.

Olshansky, R. B., Johnson, L. A., Horne, J., \& Nee, B. (2008). Longer View: Planning for the Rebuilding of New Orleans, Journal of the American Planning Association, 74(3). http://dx.doi.org/10.1080/01944360802140835

Penning-Rowsell, E. C., \& Handmer, J. W. (1988). Flood Hazard Management in Britain- A Changing Scene, The Geographical Journal, 154(2), 209-220. http://dx.doi.org/10.2307/633847

Powers, M. P. (2006). A Matter of Choice: Historical Lessons for Disaster Recovery. Hartman, Chester and Squires, Gregory D. (Eds). There Is No Such Thing As A Natural Disaster. Routledge New York and London.

Riasi, A., \& Amiri Aghdaie, S. F. (2013). Effects of a Hypothetical Iranian Accession to the World Trade Organization on Iran's Flower Industry. Consilience: The Journal of Sustainable Development, 10(1), 99-110.

Riasi, A., \& Pourmiri, S. (2015). Effects of online marketing on Iranian ecotourism industry: Economic, sociological, and cultural aspects. Management Science Letters, 5(10), 915-926.

Riasi, A., \& Pourmiri, S. (2016). Examples of Unsustainable Tourism in Middle East. Environmental Management and Sustainable Development, 5(1), 69-85.

Rosic, H., Bauer, G., \& Jammernegg, W. (2009). A framework for economic and environmental sustainability and resilience of supply chains. In Rapid modelling for increasing competitiveness (pp. 91-104). Springer London.

Sinh, B. T., Bhat, G. K., Moench, M., \& Gawler, S. (2012). Building Resilience in Asian Cities. Otto-Zimmermann (ed.). 2012. Resilient Cities 2: Cities and Adaptation to Climate Change-Proceedings of the Global Forum 2011. Springer: Dordrecht, Heidelberg, New York, London. http://dx.doi.org/10.1007/978-94-007-4223-9_24

Stecko, S., \& Barber, N. (2007). Exposing Vulnerabilities: Monsoon Floods in Mumbai, India: Case study prepared for Revisiting Urban Planning: Global Report on Human Settlements 2007 http://www.unhabitat.org/grhs/2007

Stein, J., Moreno, P., Conrad, D., \& Ellis, S. (2000). Troubled waters: Congress, the Corps of Engineers, and wasteful water projects. Washington, DC: Taxpayers for Common Sense and National Wildlife Federation.

The British Geological Survey. Retrieved from http://www.bgs.ac.uk/suds/

The City of New York. (2013). PlaNYC: A Stronger, More Resilient New York

The Minister of Transport, Public Works and Water Management (MTPWM). (2005). Flood Risks and Safety in the Netherlands. http://ec.europa.eu/ourcoast/download.cfm?fileID=1058

The Minister of Transport, Public Works and Water Management (MTPWM). (2007). Room for the River Plan. http://www.ruimtevoorderivier.nl/english/room-for-the-river-programme/

The Ministry of Transport, Public Works and Water Management (MTPWM). (2008). Flood risk: Understanding concepts. Ministry of Transport, Directorate-General of Water Affairs, Netherlands.

The National Academy of Sciences. (2012). Disaster Resilience: A National Imperative, The National Academies Press: Washington, D.C.

The National Academy of Sciences. (2013). Levees and the National Flood Insurance Program: Improving Policies and Practices, The National Academies Press: Washington, D.C.

The NYS 2100 Commission. (2013). Recommendations to Improve the Strength and Resilience of the Empire State's Infrastructure

The World Bank. (2001). World Development Report 2000/2001: Attacking Poverty. New York: Oxford University Press

The World Bank. (2013). Building Urban Resilience: Principles, Tools, and Practice.

The World Bank. (2013). Turn Down Heat the Climate Extremes, Regional Impacts, and the Case for Resilience.

Thompson, J. Phillip. (2009). Response to "Post-Disaster Planning in New Orleans, Journal of Planning Education and Research March 2009.

United Nations International Strategy for Disaster Reduction (UNISDR). (2005). Hyogo Framework for Action 2005-2015: Building the Resilience of Nations and Communities to Disasters.

United Nations International Strategy for Disaster Reduction (UNISDR). (2013). Making Cities Resilient: Summary for 
Policymakers. United Nations.

United Nations International Strategy for Disaster Reduction (UNISDR). (2012) ANNUAL REPORT 2011.

United Nations International Strategy for Disaster Reduction (UNISDR). (2015). World Conference Adopts New International Framework for Disaster Risk Reduction after Marathon Negotiations, Press release 18 March 2015UNISDR 2015/19

United Nations. (2012). World Urbanization Prospects, the 2011 Revision: Highlights. United Nations Department of Economic and Social Affairs, Population Division. New York

United Nations. (2013). The Global Assessment Report on Disaster Risk Reduction (GAR) 2013.

United Nations. (2014). Post-2015 framework for disaster risk reduction: Zero draft submitted by the co-Chairs of the Preparatory Committee. Third United Nations World Conference on Disaster Risk Reduction Preparatory Committee Second session, Geneva, 17-18 November 2014.

United Nations. (2014). Suggested elements for the post-2015 framework for disaster risk reduction. Third United Nations World Conference on Disaster Risk Reduction Preparatory Committee First session, Geneva, 14-15 July 2014

United Nations. (2015). The Global Assessment Report on Disaster Risk Reduction (GAR) 2015.

Vale, L. J., \& Campanella, T. J. (2005). The Resilient City: How Modern Cities Recover from Disaster. Oxford University Press.

Wahlström, M. (2015). How can the world better prepare for natural disasters? World Economic Forum, Agenda, March 122015 https://agenda.weforum.org/2015/03/how-can-the-world-better-prepare-for-natural-disasters/

White, I. (2010). Water and the City: Risk, Resilience and Planning for a Sustainable Future. London, Routledge.

White, M. D., \& Greer, K. A. (2006). The effects of watershed urbanization on the stream hydrology and riparian vegetation of Los Peñasquitos Creek, California. Landscape and Urban Planning, 74 (2), $125-138$. http://dx.doi.org/10.1016/j.landurbplan.2004.11.015

Wiering, M., \& Immink, I. (2006). When water management meets spatial planning: a policy-arrangements perspective. Environment and Planning C: Government and Policy 2006, 24, 423-438. http://dx.doi.org/10.1068/c0417j

Wolshon, B. (2006). The Bridge: Evacuation Planning and Engineering for Hurricane Katrina, National Academy of Engineering.

Woltjer, J., \& Al, N. (2007). Integrating Water Management and Spatial Planning, Journal of the American Planning Association, 73(2), Spring 2007.

\footnotetext{
Notes

Note 1. HFA (Framework for Action 2005-2015): In January 2005, 168 Governments adopted a 10-year plan to make the world safer from natural hazards at the World Conference on Disaster Reduction, held in Kobe, Hyogo, Japan.

Note 2. By 2050, the United Nations expects $80 \%$ of the world's population living in urban areas. Resilience planning needs to be the focus for cities.

Note 3. There are 3,455 floods and 2,689 storms in 1980-2011, an average of approximately 200 floods and storms annually over the last three decades.

Note 4. According to U.K. Environment Agency (one of the thirty-six agencies belong to the U.K. Cabinet's Department for Environment Food \& Rural Affairs), Thames Bar spans 520 meters across the River, and it protects 125 square kilometers of central London from flooding. Main gates stand as high as a 5- story building. The construction cost is approximately $\$ 796$ million (535 million GBP) in 1982. This cost is estimated at $\$ 2$ billion (1.4 billion GBP) at today's prices.

Note 5. According to U.S. Federal Emergency Management Agency (FEMA), more recent flood map products include digital flood insurance rate maps (FIRMs), which are created using digital methods and can be incorporated into a community's Geographic Information System (GIS).

Note 6. The European Flood Directive (FD) was proposed by the European Commission in 2006 to reduce and manage the flood risk. Note 7. The European Water Framework Directive (WFD) was established in 2000 as a policy platform in both quantitative water issues (cross-border flood management, water-supply management, and groundwater control) and qualitative aspects.
}

\section{(cc) BY}

This work is licensed under a Creative Commons Attribution 3.0 License. 


\title{
Innovation Front and Technology Linkage
}

\author{
Mari Jibu ${ }^{1} \&$ Yoshiyuki Osabe ${ }^{2}$ \\ ${ }^{1}$ Japan Science and Technology Agency (JST) (5-3 Yonbancho Chiyoda-ku, Tokyo 102-8666), Japan \\ ${ }^{2}$ Japan Patent Office (3-4-3 Kasumigaseki Chiyoda-ku, Tokyo 100-8915), Japan \\ Correspondence: Mari Jibu, Japan Science and Technology Agency (JST) (5-3 Yonbancho Chiyoda-ku, Tokyo \\ 102-8666), Japan
}

Received: February 2, 2016 Accepted: February 16, 2016 Online Published: February 21, 2016

doi:10.11114/bms.v2i1.1393 URL: http://dx.doi.org/10.11114/bms.v2i1.1393

\begin{abstract}
This paper presents new indicators of knowledge flows by linking scientific articles to patents. The citations between scientific articles and patents have been analyzed since Narin started the study of science linkage, which is seen in administrative process as patent examiners refer scientific articles in examining a patent (Narin, 1988, 1997). The new indicators introduced in this paper, "Innovation Front" and "Technology Linkage," are considered important, especially for policy-makers and strategy planners. These new indicators show that innovation in biotechnology field depends on a wide range of scientific knowledge and elicit a new geography of innovation hot spots.
\end{abstract}

Keywords: bibliometric analysis, patent analysis, cluster analysis, co-citation analysis, knowledge flow, innovation

\section{Introduction}

\subsection{Introduce the Problem}

Japan Science and Technology Agency (hereafter JST) is one of the funding agencies in Japan with aim of promoting technology transfers and innovation. In order to provide appropriate funding to the right place, development of new indicators for evaluation of funding effects is key issue. This made JST start the evaluation project.

Japan 4th Science and Technology Basic Plan was approved by the government in 2011, focusing on the evidence-based policymaking. It reads that the government shall promote a "Science for Science, Technology and Innovation policy" in order to plan new policies based on objective grounds (evidence) and use the results of the evaluation and verification for PDCA cycle. This reflected the criticism that policies had not been implemented based on scientific evidence. This is because a systematic database for policy making was non-existent and not available at the time. Each governmental agency or committee conducts a research of evaluation system in terms of policy making and planning. In spite of the urgent need to evaluation study, JST has successfully been able to meet the requirements because we were preparing for this kind of needs in anticipation of the 4th Science and Technology Basic Plan.

JST is a funding agency to support the technology transfer and creation of innovation. As such, it is important to take a look at the contribution of its funding. JST takes the view that Non-patent literature (NPL) in patents is considered to provide an indicator of knowledge flows between science base and innovation system. JST has developed as such an indicator, the "Technology Linkage" for analysis of the impact of research papers on patent applications. JST has also developed the "Innovation Front" for viewing specific research areas where science significantly influences technology by calculating co-citation between patents and research papers (Jibu 2011). Furthermore, JST develops analytical methods to enable visualization of the Technology Linkage and Innovation Front.

\subsection{Innovation Processes}

In order to promote innovation, it is necessary to analyze the process of innovation. The process of innovation is a chain process of the two intellectual activities, "knowledge embodiment (development)" and "knowledge creation (research)" by Yamaguchi (Yamaguchi 2010). He facilitates the visualization of innovation process in so-called "innovation diagram" by dividing the innovation process into 2 axis, that is, in the axis of the "knowledge embodiment" and in the axis of the "knowledge creation" (See Fig.1). When the development of technology becomes deadlocked (A' in Fig.1), it is necessary to review the knowledge in science level ("Induction" in Fig.1) and push forward with science research ("Abduction" in Fig.1) in order to overcome the deadlock and to generate new innovation (A* in Fig.1). It will be 
possible to make a breakthrough and generate innovation by following the actions above. Moreover, by linking science to technology, we can analyze the innovation process from A' to $A^{*}$ via $S$ and $\mathrm{P}$ in Fig.1

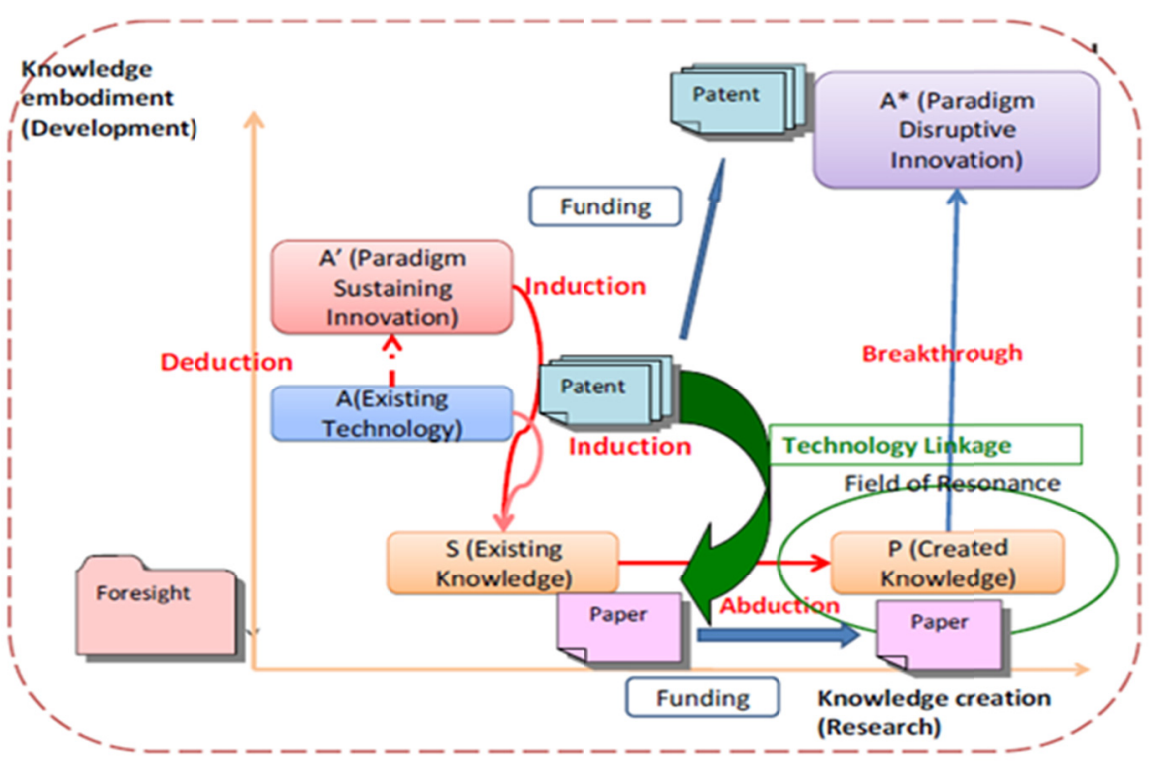

Figure 1. Innovation Process and Scientometrics

Fig. 1 shows an attempt to comprehensively understand and visualize the innovation process by embedding the functions such as bibliometric analysis, patent analysis and cluster analysis into innovation diagram. The linkage between patents and papers is important to gain an evidence-based understanding of the innovation process such as the review of science from existing technology ("Induction" in Fig.1). In the reference cited by patent examiners, we can create an index called the science linkage index, such as the share of non-patent literature (NPL) citations and the number of forward citations per cited patents, which may show whether a patent is science-oriented or technology-oriented. It is saying that backward citations to NPL show how close a patented invention is to scientific knowledge, whereas forward patent citations show the importance of a patent for the development of new technologies.

Our "Technology Linkage" can give the information on which category or area cited papers are classified into, by matching each of cited papers with the bibliography of Thomson Reuters "Web of Science", which is not only analysis use but provides a list of references in patent families. Technology Linkage makes the analysis following possible: for example, scientific knowledge linked with specific technology areas, or scientific knowledge linked with a patent family which is highly influential in the technology world (Jibu 2011).

\section{Methodology}

\subsection{Database}

The databases and technologies used in the Technology Linkage and Innovation Front are as follows:

Papers: Thomson Reuters "Web of Science”, "Essential Science Indicators"

Patents: Thomson Reuters "Derwent World Patents Index", "Derwent World Patents Citation Index"

\subsection{Classification}

\subsubsection{Papers}

(1) 272 subjects from Thomson Reuters "Web of Science" for Technology Linkage

(2) 22 category codes from Thomson Reuters "Essential Science Indicators" for Innovation Front

\subsubsection{Patents}

(1) IPC Codes for ICT, biotechnology, environment-related technologies, nuclear energy and fuel cells (OECD, 2008).

(2) ECLA codes for nanotechnology (OECD, 2008)

\subsection{Technology Linkage}

Patents were extracted from Derwent World Patents Index using the International Patent Classification (IPC) system. Patents in biotechnology are extracted by using the list of IPC codes, which is identified for the biotechnology patents by OECD (OECD, 2008). Cited articles of the patents (backward citation to NPL) were linked with papers of Web of 
Science by Thomson Reuters.

\subsection{Innovation Front}

(1) Extract two arbitrary papers which published between 2006 and 2010 from "Essential Science Indicators," calculate the forward co-citation frequency by patents in "Derwent World Patents Citation Index" and calculate frequencies of forward citations patents in the two arbitrary papers.

(2) Derive cosine coefficient $\mathrm{N}$ from (1.1).

$$
N=F(A, B) / \sqrt{F(A) \times F(B)}
$$

$$
F(A, B)>=2
$$

where A, B represent arbitrary papers, F (A), F (B) represent the cited frequency of the arbitrary papers, F (A, B) represents the co-cited frequency of the arbitrary papers. Define $\mathrm{F}(\mathrm{A}, \mathrm{B})$ is larger than or equal to 2 .

(3) Define $\mathrm{N}>=0.3$. ( $\mathrm{N}$ is larger than or equal to 0.3 )

(4) Compile the papers extracted under condition (3) as nodes, connect the linkage relationship between papers with the edge function, and visualize the network, using Cytoscape Web.

\section{Analytical Results}

\subsection{Technology Linkage}

Technology Linkage can be useful in analyzing the relationship between patents and papers. It contributes understanding the relationship between technological areas of patent family and scientific subjects of cited papers. "Technology-science linkages" of patents have also been discussed at OECD in the section of "Connecting to Knowledge" in OECD Science, Technology and Industry Scoreboard 2011 (OECD, 2011). OECD developed indicators such as the share of non-patent literature (NPL) citations and the number of forward citations per cited patent. It is saying that backward citations to NPL show how close a patented invention is to scientific knowledge. OECD analyzes that, since the proportion of backward citations to NPL is the highest in biotechnology, patented inventions in biotechnology have a close linkage to scientific knowledge comparing to those in other technologies. According to our study, the proportion of backward citations to scientific articles by patents in biotechnology account for $97 \%$. In "Technology Linkage", cited articles are classified into each category or area, by matching each of cited articles with the bibliography of Thomson Reuters "Web of Science", which is not only analysis use but provides a list of references in patent families. Technology Linkage makes the analyses following possible: for example, scientific knowledge linked with specific technology areas, or scientific knowledge linked with patent family which is highly influential in the technology world.

Subjects link with Biotechnology Patents

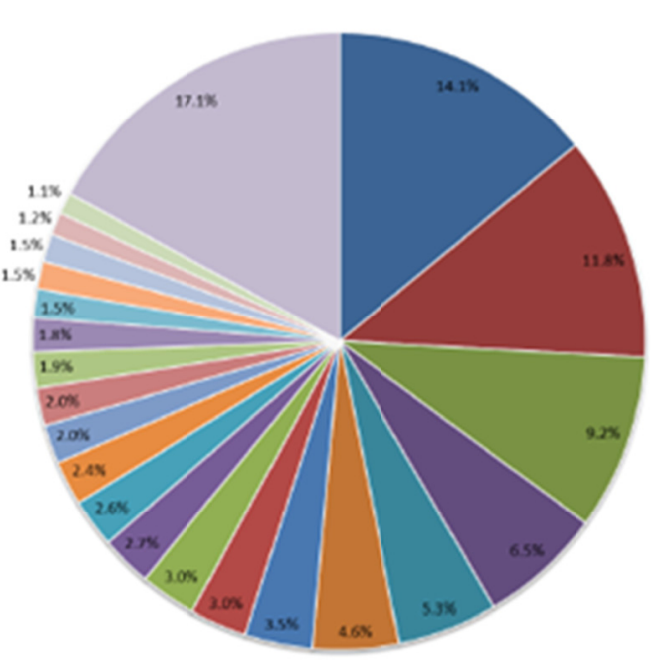

Source: Thansoon Revters "Web of Science," "Derwent World Patents inder" and "Dermet Patents Civion inder"

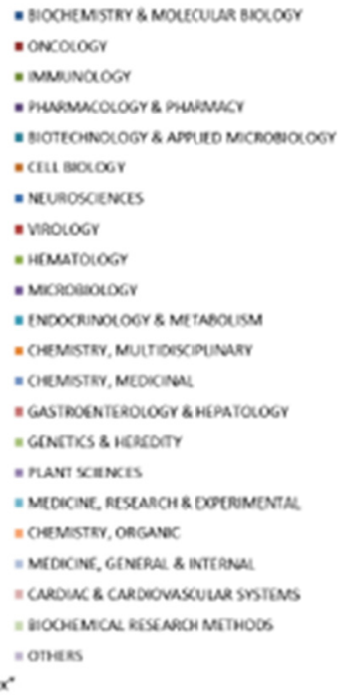

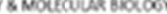

- nuvenucologrs mulawar

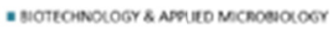

- vinotocr

- homatocos

- enoconnotoer s metranouse

- coevestar, multiolscipumer

- onensing, meocina

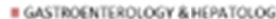

- Gonctics s icarodr

AMCH S DOTUNEVTA:

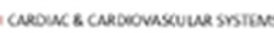

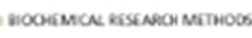

Figure 2. Subjects linked with Biotechnology Patents (2006-2010) 
Fig.2 shows which science subjects link with biotechnology patents from 2006-2010. The ratio of the number of papers in "biochemistry \& molecular biology" is the highest which accounts for $14.3 \%$, followed by "oncology" and "immunology" which account for $11.3 \%$ and $9.2 \%$ respectively. It is found that patent classified in biotechnology have highly strong linkage with these subjects.

Table 1. The number of combinations, subjects of papers and IPC code.

\begin{tabular}{|c|c|c|c|}
\hline Rank & Subject & IPC & Number \\
\hline 1 & Oncology & A61P-35/00 & 1902 \\
\hline 2 & Oncology & C12Q-1/68 & 1716 \\
\hline 3 & $\begin{array}{l}\text { Biochemistry \& } \\
\text { Molecular Biology }\end{array}$ & C12N-15/09 & 1419 \\
\hline 4 & Oncology & G01N-33/574 & 1222 \\
\hline 5 & $\begin{array}{l}\text { Biochemistry \& } \\
\text { Molecular Biology }\end{array}$ & C12Q-1/68 & 1197 \\
\hline 6 & Oncology & C12N-15/09 & 1073 \\
\hline 7 & Oncology & G01N-33/53 & 1024 \\
\hline 8 & $\begin{array}{l}\text { Biochemistry \& } \\
\text { Molecular Biology }\end{array}$ & $\mathrm{C} 07 \mathrm{H}-21 / 00$ & 1018 \\
\hline 9 & Oncology & A61K-39/395 & 1016 \\
\hline 10 & $\begin{array}{l}\text { Biochemistry \& } \\
\text { Molecular Biology }\end{array}$ & A61P-35/00 & 945 \\
\hline 11 & $\begin{array}{l}\text { Biochemistry \& } \\
\text { Molecular Biology }\end{array}$ & $\mathrm{C} 07 \mathrm{H}-21 / 04$ & 894 \\
\hline 12 & $\begin{array}{l}\text { Biochemistry \& } \\
\text { Molecular Biology }\end{array}$ & $\mathrm{C} 12 \mathrm{~N}-5 / 10$ & 884 \\
\hline 13 & Immunology & A61K-39/00 & 852 \\
\hline 14 & $\begin{array}{l}\text { Biochemistry \& } \\
\text { Molecular Biology }\end{array}$ & G01N-33/53 & 851 \\
\hline 15 & $\begin{array}{l}\text { Biochemistry \& } \\
\text { Molecular Biology }\end{array}$ & C07K-14/435 & 839 \\
\hline 16 & $\begin{array}{l}\text { Biochemistry \& } \\
\text { Molecular Biology }\end{array}$ & A61K-38/00 & 811 \\
\hline 17 & Oncology & C07H-21/00 & 799 \\
\hline 18 & Oncology & A61K-38/00 & 791 \\
\hline 19 & Oncology & A61P-43/00 & 776 \\
\hline 20 & Immunology & C12N-15/09 & 755 \\
\hline
\end{tabular}

Table 1 shows the number of combinations, subjects of papers and IPC Codes. The highest number of combinations is (A61P35/00, Oncology), followed by (C12Q1/68, Oncology) and (C12N15/09, Biochemistry \& Molecular Biology) ${ }^{1}$.

According to the chain-linked model of innovation, basic research in the first and foremost stage contributes not only to existing knowledge but also innovation coming, especially it is of particular note in the biotechnology field. Research in oncology directly and indirectly influences on technologies of Antineoplastic agents and measuring or testing processes involving enzymes or micro-organism.

\subsection{Innovation Front}

"Innovation Front" analyzes articles cited in patent families by co-citation analysis. Since articles cited in patent families are close to technology, it is possible to find major researchers and scientific specialties of articles which influence technology. Thomson Reuters publishes papers with high impact in Science Watch by assigning them as a research front based on the analysis of co-citation frequency of papers. By using the same approach, JST clusters the top $1 \%$ of the most-cited papers which are co-cited by patents and facilitates their visualization as a cluster having an effect on technology and innovation. It has christened the papers having an effect on technology with "Innovation Front". The figure 3 shows the result of the Innovation Front.

\footnotetext{
${ }^{1}$ A61P: SPECIFIC THERAPEUTIC ACTIVITY OF CHEMICAL COMPOUNDS OR MEDICINAL PREPARATIONS A61P35/00: Antineoplastic agents C12Q: MEASURING OR TESTING PROCESSES INVOLVING ENZYMES OR MICRO-ORGANISMS

C12Q1/68: involving nucleic acids C12N: MICRO-ORGANISMS OR ENZYMES; COMPOSITIONS THEREOF

C12N15/09: Recombinant DNA-technology

For other IPCs, see the URL below:

http://www.wipo.int/classifications/ipc/en/
} 


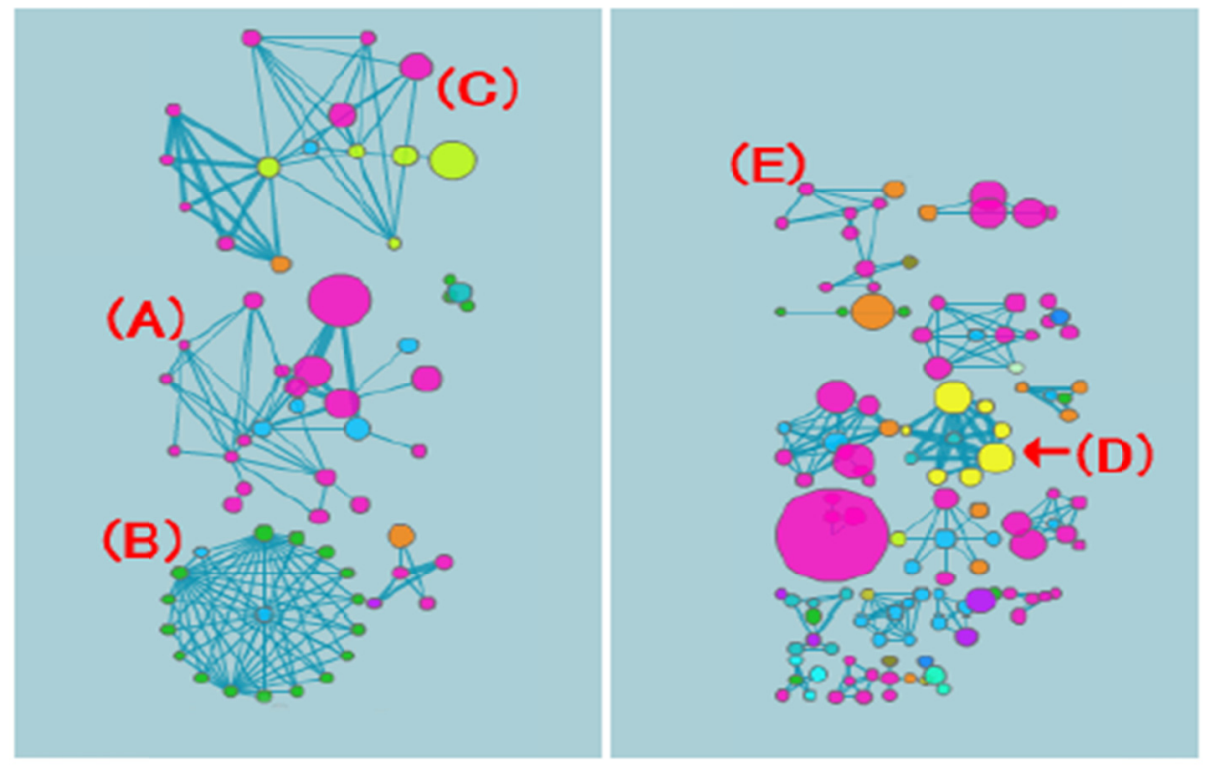

Figure 3. Innovation Front

Nodes express papers and the colours of the nodes represent 22 fields. The size of the nodes represents the number of citations in papers. The line width of edge represents the number of co-citations by patent families. As a result, 24 clusters consisting of 183 papers in total were created. Total citations of patent families are 1,095 and those of papers are 46,038. By looking at the categories, the clinical medicine category is the largest with 83 articles, followed chemistry category with 26 , and the biology/biochemistry category with 24 . The most frequently published journal is Science, with 18 articles followed by NATURE 17, Journal of American Chemical Society 12. Concerning subjects of papers in clusters of Innovation Front: the largest subject is clinical medicine which account for $45.4 \%$, followed by chemistry which accounts for $14.2 \%$.

Cluster (A) is the science field of induced pluripotent stem cells (iPS cells), composed by 22 articles. The core article's title is "Induction of Pluripotent Stem Cells from Adult Human Fibroblasts by Defined Factors", written by Takahashi, K. et. al. and published in Cell, 2007. Cluster (B) is the science field of Aptamor, composed by 18 articles in engineering and chemistry. The core article's title is "Colorimetric Detection of Mercuric Ion (Hg2+) in Aqueous Media using DNA-Functionalized Gold Nanoparticles" written by Lee, J. S. et. al. in NORTHWESTERN University and published in Angewandte Chemie International Edition, 2007. Cluster (C) is the science field of Adipo-cytokine, composed by 15 articles in clinical medicine, Immunology, biology/biochemistry. The core article's title is "TGF beta in the context of an inflammatory cytokine milieu supports de novo differentiation of IL-17-producing T cells" written by Veldhoen, M. et. al. in National Institute for Medical Research and published in Immunity, 2006. Cluster (D) is the science field of Meta-material, composed by 9 articles in physics. The core article's title is "Controlling electromagnetic fields" written by Pendry J. B. et. al. in Imperial College London and published in Science, 2006. Cluster (E) is the science field of MicroRNA and Cardiac Hypertrophy, composed 9 articles in clinical medicine and neuroscience and behavior. The core article's title is "Regulation of cardiac hypertrophy by intracellular signaling pathways", written by Heineke in University of Cincinnati. This Article is published in Nature Reviews Molecular Cell Biology, 2006. 


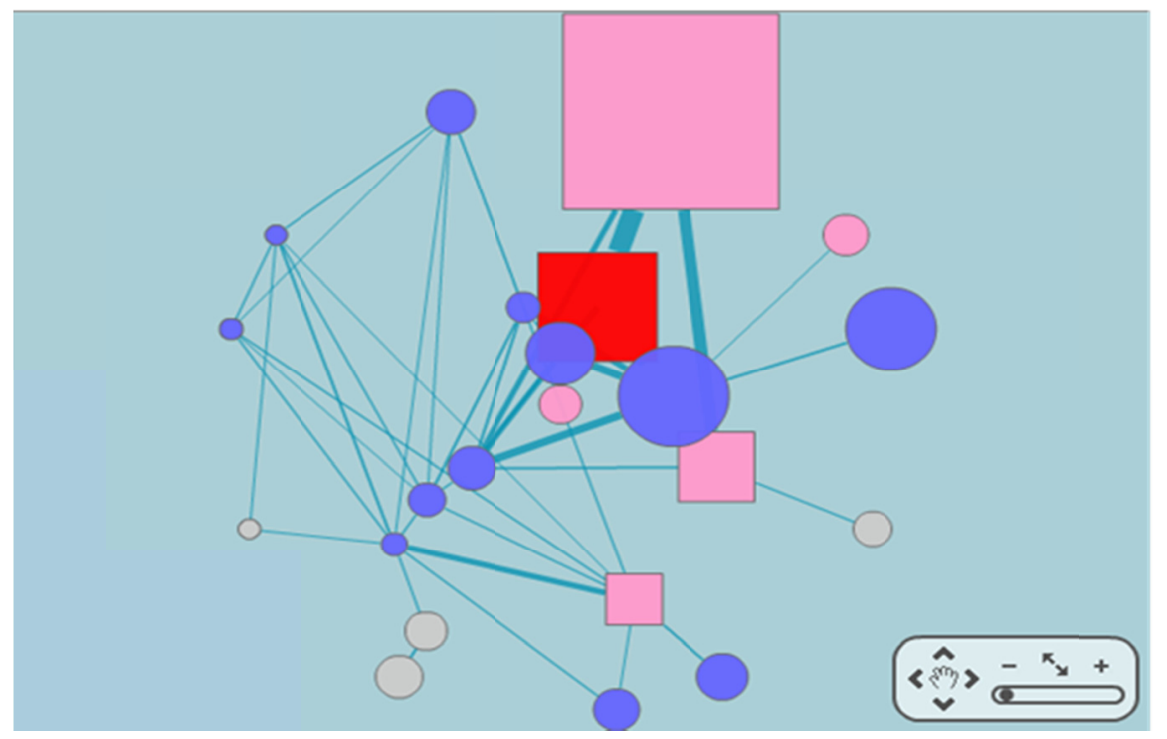

Figure 4. iPS cells cluster in Innovation Front

Fig.4 shows the details of cluster A which is the specific scientific field of iPS cells composed by 22 papers and the number of citations of the papers are 7,517. Squares indicate papers written by Yamanaka group and the Largest square, the core article is "Induction of Pluripotent Stem Cells from Adult Human Fibroblasts by Defined Factors", written by Yamanaka Shinya. This article was published in Cell, 2007. The Nobel Prize in Physiology or Medicine 2012 was awarded jointly to Sir John B. Gurdon and Shinya Yamanaka "for the discovery that mature cells can be reprogrammed to become pluripotent". The Press Release by the Nobel Assembly at Karolinska Institute announced "Induction of pluripotent stem cells from mouse embryonic and adult fibroblast cultures by defined factors" by Takahashi, $\mathrm{K}$ and Yamanaka, S. as one of key publications (The Press Release o by the Nobel Assembly, 2012). This article's target is the iPS cells derived from mouse embryonic and adult fibroblast cultures. On the other hand, the core article of Innovation Front is "Induction of Pluripotent Stem Cells from Adult Human Fibroblasts by Defined Factors" by Takahashi, K and Yamanaka, S. The core article's target of Innovation Front is the iPS cells derived from human fibroblasts. Subjects for study change from in vitro, in vivo, mice, apes and to humans, as the study advances from basic to practical research. Innovation Front is able to find hot scientific papers and specific fields (clusters) composed by the papers that affect the technology close to practical stage. This is the reason why core paper of Innovation Front is the paper that target humans instead of mice or in vitro study. Other papers of iPS cells research also target humans. Papers composed of Innovation Front are almost 6 groups as follows:

Articles of Node 1 were written by International Consortium of Stem Cell Networks which is a consortium of researchers from around the world for making benchmarks for human embryonic stem cell research. Articles of Node 2 were written by Yamanaka S. (Kyoto University) group. Yamanaka group succeeded in converting mice cells and human skin cells into iPS cells. Articles of Node 3 were written by Thomson J. A. (University of Wisconsin) group. Thomson group succeeded in isolating the first human embryonic stem (ES) cells in 1998 and converting human skin cells into iPS cells at almost the same time as Yamanaka group, 2007. Articles of Node 4 were written by Schoeler H. R. (Max Planck Institute) group. Schoeler groups succeeded in reprogramming of adult mouse neural stem cells to pluripotency by requiring Oct4 instead of Oct4, Klf4, c-Myc and Sox2.

Articles of Node 5 were written by Jaenisch R. (MIT) group. Jaenisch group succeeded in reprograming from mature, differentiated mouse B cells to iPS cells and finding alternatives to the potentially cancer-causing retroviruses used to transform the adults cells into iPS cells. Articles of Node 6 were written by Hochedlinger, K. (Harvard University) group. Hoshcedlinger group used an adenovirus to transport the requisite four transcription factors into the DNA of skin and liver cells.

\section{Conclusion}

This paper proposes new indicators: "Technology Linkage" and "Innovation Front" for measuring knowledge flows. Technology Linkage shows the relationship between technology and scientific knowledge, especially what kind of scientific knowledge a technology is based on. Innovation Front shows "new geography of innovation hot spots."

Our main findings from indicators, Innovation Front and Technology Linkage, are as follows; 
(1) Citations to scientific articles by patents in biotechnology account for $97 \%$.

(2) Technologies in biotechnology are based on a wide range of scientific knowledge: the largest subject is Biochemistry \& Molecular Biology which accounts for 14.3\%, followed by Oncology and Immunology which account for $11.3 \%$ and $9.2 \%$ respectively.

(3) The diversity of scientific sources contributes to innovation in biotechnology.

(4) Subjects of papers in clusters of Innovation Front: the largest subject is clinical medicine which accounts for 45.4\%, followed by chemistry which accounts for $14.2 \%$.

(5) Specific science areas recognized as innovation hot spots 2006-2010 are induced pluripotent stem cells, Adipo-cytokine and MicroRNA and Cardiac Hypertrophy.

Taken together, we consider our results help illuminate new indicators for knowledge flow for innovation. Future work will be built on our result with other valuable data, for example, product data and intangible assets.

\section{Addendum}

Note that the opinions expressed in this paper are those of the authors and do not represent those of the institutions that the authors belong to.

\section{References}

Booth, B., \& Zemmel, R. (2004). Prospects for Productivity. Nature Reviews Drug Discovery, 3, 451-456. http://dx.doi.org/10.1038/nrd1384

Jibu, M. (2011). Analysis Achievements of JST Operations through Scientific Patenting: Linkage between Patents and Scientific Papers. Atlanta conference on Science and Innovation Policy, IEEE. 214-220. http://dx.doi.org/10.1109/acsip.2011.6064473

Jibu, M., \& Osabe, Y. (2014). Refined R\&D Indicators for Pharmaceutical Industry. Future Information Technology, Lecutre Notes in Electrical Engineering, 309, 549-554. http://dx.doi.org/10.1007/978-3-642-55038-6_86

Lerner, J. (1994). The Importance of Patent Scope: An Empirical Analysis. The RAND Journal of Economics. 25(2), 219-333. http://dx.doi.org/10.2307/2555833

Narin, F., \& Pozek, R. P. (1988). Bibliometric Analysis of US Pharmaceutical Industry Research Performance, Research Policy, 17, 317-330. http://dx.doi.org/10.1016/0048-7333(88)90039-X

Narin, F., Hamilton, K., \& Olibastro, D., (1997). The increasing linkage between US technology and public science. Research Policy 26, 317-330. http://dx.doi.org/10.1016/S0048-7333(97)00013-9

OECD. (2008). Compendium of Patent Statistics, 2008. Organization for Economic Co-operation and Development.

OECD. (2011). OECD Science, Technology and Industry Scoreboard 2011: Innovation and Growth in Knowledge Economics. Organization for Economic Co-operation and Development.

http://dx.doi.org/10.1787/sti_scoreboard-2011-en

OECD. (2013). OECD Science, Technoogy and Industry Scoreboard 2013: Innovation for Growth. Paris, France OECD Publishing. http://dx.doi.org/10.1787/sti_scoreboard-2013-en

Porter, A. L., \& Ashton, W. B. "Foresight in the USA" in The Handbook of Technology Foresight edited by Luke Georghiou, Jennifer C. Harper, Michael Keenn, Ian Miles and Rafael Popper Edward Elgar Publishing Limited p154 2008.

The Nobel Assembly at Karolinska Institute. (2012), Press Release. The Nobel Assembly at Karolinska Institute. http://www.nobelprize.org/nobel_prizes/medicine/laureates/2012/press.html Accessed 1, February 2016

Yamaguchi, E. (2010). Innovation theory leading to breakthrough -How will the memory device industry face the "post-Moore" future?, Oyo Buturi, 79(12), 1077-1083.

\section{(cc) $\mathrm{EY}$}

This work is licensed under a Creative Commons Attribution 3.0 License. 


\title{
Impact of Corporate Advertising on Consumers' Attitudes toward Products
}

\author{
Benedikt Spangardt \\ Correspondence: Benedikt Spangardt, University of Würzburg, Media and Business Communication, Os- \\ wald-Külpe-Weg 82, 97074 Würzburg, Germany
}

\author{
Received: February 14, 2016 Accepted: February 16, 2016 Online Published: February 21, 2016 \\ doi:10.11114/bms.v2i1.1394 URL: http://dx.doi.org/10.11114/bms.v2i1.1394
}

\begin{abstract}
Corporate advertising - advertising designed to build and maintain corporate image rather than to promote sales - is becoming increasingly important for many companies. In addition to the questions regarding whether, and, if so, how corporate advertising contributes to the goal of building and maintaining corporate image, one could also ask if it influences other areas of a company. In this study, corporate advertising was assumed to affect consumer attitudes toward company products, even if the advertising promoted the company in general terms but did not feature any products. The results of an online survey involving 408 participants indicate that corporate advertising has a marked effect on consumer attitudes toward company products, and that this effect could be influenced by product involvement.
\end{abstract}

Keywords: corporate advertising, marketing, corporate communications, involvement, heuristics

\section{Introduction}

Corporate advertising has gained increasing importance in recent years. Many companies invest in advertising primarily designed to boost corporate image as opposed to sales. Even large multinational corporations and holdings such as Procter \& Gamble and Unilever are increasingly focusing on brand image (Marshall \& Wise, 2013). This is not a new phenomenon, at least with regard to the Anglo-American market; between 1970 and 1990, a small number of studies were published on this issue (Schumann, Hathcote, \& West, 1991). In the 1980s it was stated that 'corporate advertising has received greater attention over the past decade' (Crane, 1990, p. 31), while in the 1990s, a triennial study conducted by the Association of National Advertisers revealed that between 1995 and 1997, two-thirds of all US-owned companies employed corporate advertising to the sum of approximately US\$16 million (Cardona, 1998). In 2004, corporate advertising generated approximately 11 billion dollars in profit for the advertising industry (Belch \& Belch, 2004). The last notable research review that explicitly discussed corporate advertising was that of Schumann et al. (1991).

As far back as the eighties, Patti and McDonald (1985) predicted that corporate advertising would become more important; however, scientific analysis of this issue remains rare, generally dealing with very specific phenomena. As previously noted, 'the use of corporate advertising [...] has increased, but only limited research has been done to explore the nature of it' (Kim, Haley, \& Koo, 2009, p. 67).

During the past 30 years, research has e.g. examined corporate advertising messages (Ho \& Hallahan, 2004; Hwang, McMillan, \& Lee, 2003), its objectives of influencing corporate image (Haley 1996; Jørgensen \& Isaksson, 2008; Schumann, Hathcote, \& West, 1991), and its effects on perceptions and attitudes (Burgoon, Pfau, \& Birk, 1995; Javalgi, Taylor, Gross, \& Lampman, 1994; Kim \& Choi, 2014; Pashupati, Arpan, \& Nikolaev, 2002; Winters 1986). However, few studies have examined corporate advertising in markets outside the US (Frauscher \& Signitzer, 1991; McLeod \& Kunita, 1994).

Results from studies by Sheinin and Biehal (1999), Gürhan-Canli and Batra (2004), Biehal and Sheinin (2007), Kim, Haley and Lee (2008) and Kim et al. (2009) suggest that there is a relationship between corporate advertising and consumers' attitude toward product ads, product images and products of the same company in general. Corporate advertising seems to have an influence on consumers' attitudes toward products. However, the nature of this influence remains unclear. The aim of this paper is to contribute to its clarification. Therefore, this paper examines whether presenting a corporate ad or not affects consumer's general perception of a product. Furthermore, the influence of product involvement is analyzed.

This paper begins by discussing the term corporate advertising, as a variety of definitions of corporate advertising have been suggested. Then, the theoretical background on the relationship between corporate advertising and consumers' 
attitudes toward products is briefly outlined and leads toward the hypotheses. The remaining part of the paper shows how the hypotheses were tested by means of an online experimental study. Results are presented and discussed at the end.

\subsection{Corporate Advertising}

Corporate advertising comprises a complex set of facets, and is therefore difficult to define in a specific and consistent way (Garbett, 1981, 1983; Kerr, 2003; Schumann et al., 1991). Kerr (2003) uses the term 'corporate advertising' as a matter of course, but in fact the meaning is commonly somewhat unclear. To avoid confusion and provide a clear definition of the term used within the scope of the present study, a short overview of the various forms and definitions of 'corporate advertising' is provided below.

It is difficult to find a common term that describes the phenomenon whereby companies employ advertising not only for their products and services, but also for themselves. Currently, various forms of corporate advertising, including 'institutional advertising', 'image advertising', 'issue advertising', and 'umbrella advertising' exist in parallel and are not sufficiently differentiated one from one another (Crane, 1990; McLeod \& Kunita, 1994; Patti \& MacDonald, 1985).

As mentioned above, a common consensus regarding the definition of 'corporate advertising' is that it is not employed to promote services or products (Garbett, 1983; Rau \& Preble, 1988). Corporate Advertising is also not designed to ask some action on the part of the audience beyond passive approval and a favorable attitude towards the company (Sethi, 1979). Contrary to classical product or consumer advertising, corporate advertising is often referred to as a form of communication designed to influence the 'corporate-social environment' (McLeod \& Kunita, 1994, p. 13). The primary goals of corporate advertising are to build and maintain a specific corporate image (Pashupati et al., 2002; Schumann et al., 1991), as well as a strong reputation (Jørgensen \& Isaaksson, 2008). Corporate advertising also seeks to help companies gain the trust of consumers (Smith, Smith, \& Dunbar, 2014). Corporate advertising can clearly be seen residing at the junction between classical advertising (as part of marketing strategy) and public relations, because notwithstanding the term advertising and the use of paid media space and classical forms of advertising, trust becomes a central tenet. The concept of using communication to build trust towards an organization is well known from research in the field of public relations (Broom, 2012; Ledingham \& Bruning, 1998).

Furthermore, due to its supposed proximity to public relations, corporate advertising is seen as a tool for crisis communication (Kerr, 2003). Previous research in this field by Kim and Choi (2014) suggested that corporate advertising is used when the company is criticized; i.e., when public sentiment regarding the company (or other types of organizations, cf. Ho \& Hallahan, 2004) becomes negative. In this context, previous studies have examined whether corporate advertising can help minimize the damage to a company's brand image and reputation as the result of a crisis, serving as a type of buffer against negative news (Pashupati et al., 2002; Smith et al., 2014; Winters, 1986). Therefore, research on corporate advertising is often conducted using examples of businesses with an increased risk of damage to their public image, such as companies in the energy (oil) sector (Kerr, 2003; Smith et al., 2014; Winters, 1983, 1986) or financial services industries (Bobinski \& Ramirez, 1994; Crane, 1990; Jørgensen \& Isaaksson, 2008).

However, most of these studies share the common belief that corporate advertising is not employed to improve sales. This sets the foundation for the following definition of corporate advertising, which will be employed in the remainder of this paper: Corporate advertising is a planned process of communication designed to convey a certain corporate image to the recipients and intended to create and maintain acceptance, credibility, and trust for and in the company. For these purposes, corporate advertising uses the (classical) means of advertising, and is usually distributed using paid media space. The content of such ads typically involves descriptions and delineations of the self-image and the actions of the company, never for a specific product. If products do appear in the ads, they are not specifically referred to, emphasized, or set in the foreground.

\subsection{Pass-through onto Products}

Although corporate advertising is often described as a type of advertising that does not promote a specific product, the position of this paper is that a corporation cannot be regarded as independent of its products. In most cases, consumers are conscious to some extent of the company and its products, thereby firmly linking the two. Among consumers, knowledge about and attitudes toward a company have been reported to influence their knowledge about and attitudes toward products newly introduced to the market (Brown \& Dacin, 1997).

It is generally assumed that advertising influences stakeholders beyond those who are actually targeted. For example, recruitment advertising can strengthen brands in general, even among individuals who are not potential employees (Collins \& Stevens, 2002; Wilden, Gudergan, \& Lings, 2010). Kerr (2003) reported that a corporate ad campaign by Shell positively affected their product sales, and Rosengren and Bondesson (2014) found that product or consumer advertising can have an impact on other stakeholders such as financial investors or job applicants. Roughly speaking, 
this is the 'reverse' effect of that which the present study aims to explain - the impact of corporate advertising on a particular group of stakeholders, namely consumers.

Consumers retain the knowledge they gain from a corporate ad and integrate it with their knowledge of the company (Homer, 1990; MacKenzie, Lutz, \& Belch, 1986). This would substantially support one of the goals of corporate advertising listed above, which is to build and maintain a positive corporate image (Schumann et al., 1991). Additionally, Kelly and Edwards (1998) have reported that consumers generally prefer image ads over product advertisements. The former were liked better and were considered as more persuasive by the participants.

Similar to brand knowledge, knowledge about a company includes attitudes, opinions, and effects (Garbett, 1981; Keller, 2001; MacKenzie et al., 1986). Each of these factors can influence consumer attitudes toward products; these attitudes result from a combination of spontaneous impressions and knowledge retrieved from memory. Knowledge retrieval is influenced by retrieval cues such as brand names and logos (Keller, 1987; Biehal \& Sheinin, 1998), and this retrieved knowledge can influence new and old attitudes alike (Sheinin \& Biehal, 1999). However, Sheinin and Biehal also assumed that corporate advertising previously seen by consumers affected their reaction to a product presented by that company; therefore, they only examined the effects of corporate advertising on attitudes toward product ads, not the actual product itself, and thus only asked subjects to assess print ads for products after showing them corporate ads.

\subsection{Hypotheses}

These considerations lead to the following question: when a product is presented to consumers, do they assess it differently based on whether they have been shown a corporate ad from the company? This question is the basis for the first hypothesis:

$\mathrm{H}_{1}$ : Consumers who are shown a corporate ad assess a product manufactured by the company in the ad differently than those who are not shown a corporate ad.

As described above, the retrieval of information gained from corporate advertising can be viewed as a heuristic process in terms of the Elaboration Likelihood Model (ELM). According to the ELM, individuals fall back to such a heuristic approach when the strength of elaboration during product assessment is not high (i.e., if it is a low-involvement product for the consumer). If a company places a retrieval cue on a product, it will serve as a peripheral cue during the mental assessment of that product (Petty, Brinol, \& Priester, 2011; Petty \& Cacioppo, 1986), which causes the consumer to regress to the information gained from corporate advertising. These considerations lead to the second hypothesis of this study:

$\mathrm{H}_{2}$ : The effect proposed in $\mathrm{H}_{1}$ is stronger during assessment of a low-involvement product compared with a high-involvement product.

\section{Method}

\subsection{Design}

An online experiment was designed as a $2 \times 2$ between-subject experiment. The participants were recruited through various channels on the Internet and followed a link to an online survey form. After a short introduction, approximately half of the participants were shown a TV spot that included a corporate ad. Within this group, approximately $50 \%$ watched a corporate ad for Samsung, while the other half watched a corporate ad for Nestlé. Neither of the spots featured a specific company product. In fact, both ads contained various statements about the company's general aims, atmosphere, or traditions. Next, the participants were asked to judge a product manufactured by each of the companies. One product ('Smarties', a chocolate confectionery produced by Nestlé) was intended to represent a low-involvement product, while the other product ('Galaxy Tab 3', a tablet computer manufactured by Samsung) was intended to represent a high-involvement product.

Participants in the second group were also asked to assess each of these products, but without having viewed any type of corporate advertising beforehand. The product images were chosen such that the recipients could clearly recognize the logo of the company as a retrieval cue (Keller, 1987; Biehal \& Sheinin, 1998).

The questionnaire was filled in by 613 persons. Participants were randomly assigned to the two groups using survey software ('Unipark' by QuestBack GmbH, Cologne). After excluding 205 cases due to irregularities such as missing information, not completing the questionnaire or taking either too much or not enough time to fill in the questionnaire, a total of 408 cases $\left(61.3 \%\right.$ female; mean age $\left[M_{\text {age }}\right]=27.12$ years, standard deviation $[S D]=12.13$ years $)$ were analyzed. 
Table 1 . The $2 \times 2$ between-subject design used in the present study

\begin{tabular}{|c|c|c|}
\hline & $\begin{array}{l}\text { low involvement product } \\
\text { 'Smarties' }\end{array}$ & $\begin{array}{l}\text { high involvement product } \\
\text { 'Galaxy Tab 3' }\end{array}$ \\
\hline \multirow{3}{*}{$\begin{array}{l}\text { without } \\
\text { corporate advertising }\end{array}$} & control group 1 & control group 2 \\
\hline & (low involvement) & (high involvement) \\
\hline & $N=105$ & $N=105$ \\
\hline \multirow{3}{*}{$\begin{array}{c}\text { with } \\
\text { corporate advertising }\end{array}$} & experimental group 1 (low & experimental group 2 (high \\
\hline & involvement) & involvement) \\
\hline & $N=116$ & $N=82$ \\
\hline
\end{tabular}

\subsection{Measures}

The independent variable 'product involvement' was measured using a scale slightly modified from that used by Zaichowski (1985). Participants were shown a four-point semantic differential with 10 bipolar adjectives (with ' 1 ' representing the negative end of the scale and ' 4 ' representing the positive end). An index was formed using these 10 variables (Cronbach's $\alpha=.91$ ). For a manipulation check to assess whether the two products actually matched the hypothesis of being high- or low-involvement products, differences in involvement were assessed. The tablet computer was shown to be a significantly higher-involvement product $(M=2.76 ; S D=.66)$ than the chocolate confectionery $(M=2.29 ; S D$ $=.58 ; t(371.34)=-7.54 ; p=.00)$.

The dependent variable 'attitude toward the product' was measured using 20 items on a four-point Likert scale from 'completely false' (1) to 'completely true' (4). Items were taken from Benedek and Miner (2002) and complemented with additional items. To achieve dimension reduction, principal factor analysis was conducted on the 20 items. Because we expected the factors not to be completely independent of each other, and orthogonal rotation is not recommended when correlated factors are expected, we conducted the analysis using oblique rotation (direct oblimin) as suggested by Fabrigar, Wegener, MacCallum and Strahan (1999) and Russell (2002). The Kaiser-Meyer-Olkin (KMO) criterion verified the adequacy of the variables in the sample $(K M O=.911$; 'marvelous' according to Hutcheson and Sofroniou, 1999).

Taken together, the four factors listed in Table 2 explain $63.84 \%$ of the variance after rotation. Factor 1 represented the attitude toward the product as 'attractive'. Factor 2 was labeled 'social', Factor 3 'exciting', and Factor 4 'emotional'. The corresponding indices were formed, yielding satisfactory reliabilities as follows: $\alpha_{\text {attractive }}=.83, \alpha_{\text {social }}=.80, \alpha_{\text {exciting }}$ $=.77$ and $\alpha_{\text {emotional }}=.79$.

Table 2. Pattern matrix of a factor analysis for 20 items of attitude towards products (principal axis factoring extraction with oblimin rotation)

\section{Results}

\begin{tabular}{|c|c|c|c|c|}
\hline \multirow{2}{*}{$\begin{array}{l}\text { item } \\
\text { (attitude toward product) }\end{array}$} & \multicolumn{4}{|c|}{ factor } \\
\hline & 1 & 2 & 3 & 4 \\
\hline reliable & .762 & & & \\
\hline high quality & .753 & & & \\
\hline useful & .746 & & & \\
\hline appealing & .567 & & & \\
\hline trustworthy & .562 & & & \\
\hline innovative & .559 & & & \\
\hline sustainable & .465 & & & \\
\hline traditional & & .825 & & \\
\hline family-oriented & & .754 & & \\
\hline familiar & & .621 & & \\
\hline collaborative & & .520 & & \\
\hline fun & & & .845 & \\
\hline exciting & & & .735 & \\
\hline desirable & & & .555 & \\
\hline emotional & & & & -.837 \\
\hline passionate & & & & -.835 \\
\hline creative & & & & -.497 \\
\hline
\end{tabular}

$\mathrm{H}_{1}$ states that participants who are shown a corporate ad will assess a product related to the respective company differently than those who are not exposed to a corporate ad. To test this hypothesis, mean differences between the experimental and control groups were analyzed for each of the four dimensions of attitude toward the relevant product. Significant differences with small to medium effect sizes were found in every dimension; after being exposed to a TV spot that included a corporate ad, participants assessed the product as being significantly more attractive, social, and emotional, and less exciting (Table 3). The considerable mean differences and medium effect sizes in the 'social' and 'emotional' dimensions could be explained based on the content of the TV spots focusing on social living, family, and tradi- 
tion. Without conducting an actual content analysis of the TV spot, it could be stated that the spot induced a quiet and comfortable atmosphere. This could have influenced the attitude toward the product as being less exciting among the members of the control group. However, $\mathrm{H}_{1}$ is considered verified because the predicted effect was found: corporate advertising significantly affects consumer attitudes toward a product manufactured by that company.

Table 3. Differences in attitudes toward products with and without prior exposure to corporate advertising

\begin{tabular}{|c|c|c|c|c|c|c|c|c|}
\hline \multirow{2}{*}{$\begin{array}{l}\text { attitude toward } \\
\text { the product }\end{array}$} & \multicolumn{2}{|c|}{$\begin{array}{c}\text { Group 1 } \\
\text { (with corporate ad) }\end{array}$} & \multicolumn{2}{|c|}{$\begin{array}{c}\text { Group } 2 \\
\text { (without corporate ad) }\end{array}$} & \multirow[b]{2}{*}{$d f$} & \multirow[b]{2}{*}{$t$} & \multirow[b]{2}{*}{$p$} & \multirow[b]{2}{*}{$d$} \\
\hline & $M$ & $S D$ & $M$ & $S D$ & & & & \\
\hline 'attractive' & 2.72 & .64 & 2.60 & .57 & 406 & 1.98 & .048 & .20 \\
\hline 'social' & 2.61 & .82 & 2.33 & .86 & 406 & 3.41 & .001 & .33 \\
\hline 'exciting’ & 2.59 & .71 & 2.78 & .64 & 406 & -2.72 & .007 & .28 \\
\hline 'emotional' & 2.60 & .80 & 2.19 & .68 & 386.11 & 5.49 & $\leq .001$ & .55 \\
\hline
\end{tabular}

Note. $\mathrm{n}_{\text {Group } 1}=198, \mathrm{n}_{\text {Group } 2}=210$; 'Attitude toward the product' was measured on a four-point scale from $1=$ not at all true, to 4 = completely true; $d=$ measure of effect size 'Cohen's d';

$\mathrm{H}_{2}$ stated that differences in attitudes toward products between the experimental and control groups would be stronger under the condition of low- than high-product involvement. This was true for the dependent variables 'attractive' and 'exciting'. While the attitude toward the product showed little variation between the two groups under the condition of high-product involvement, a mean difference was evident under the condition of low-product involvement (cf. Figures 1 and 2).

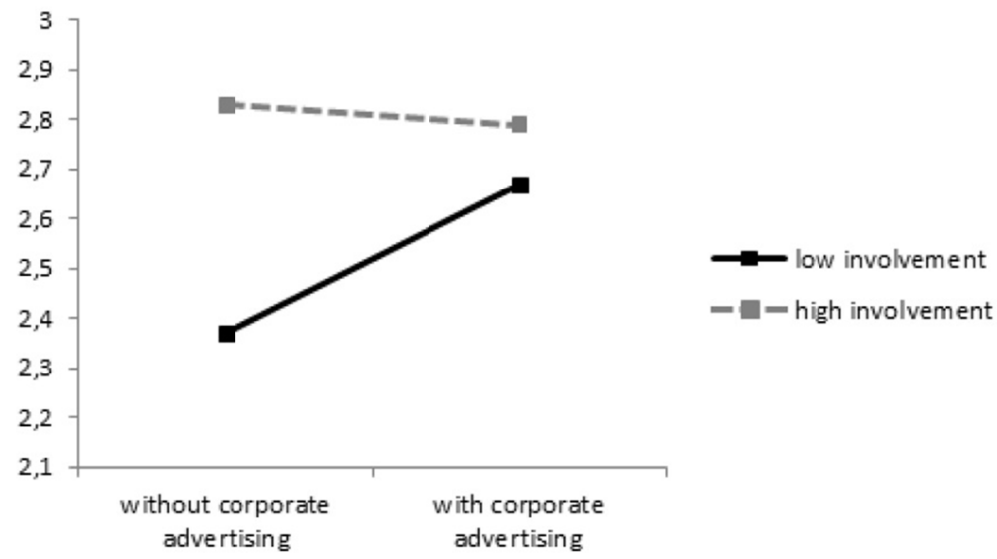

Figure 1. Attitudes toward products viewed as 'attractive': differences based on involvement and presence or absence of corporate advertising.

Note. Vertical axis shows the extent to which participants judged the product as 'attractive' (1-to-4-scale). The interaction effect was significant $\left(F(1,404)=8.66 ; p<0.01\right.$; partial $\left.\eta^{2}=.021\right)$.

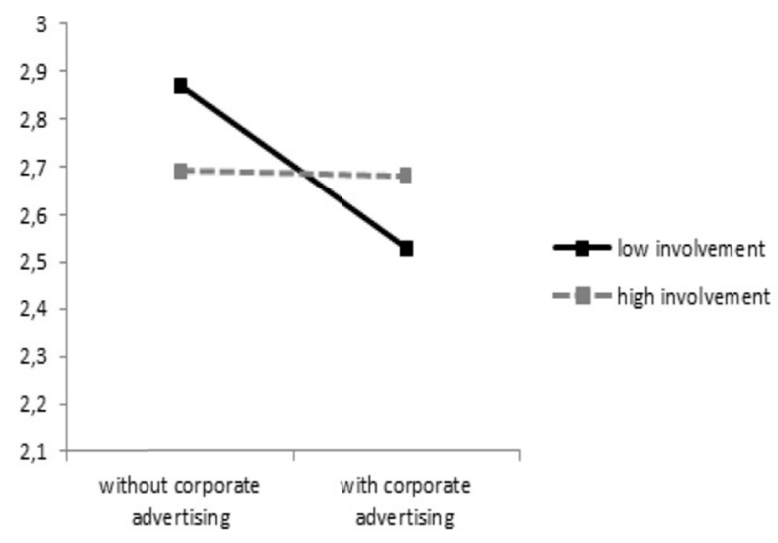

Figure 2. Attitudes toward products viewed as 'exciting': differences based on involvement and presence or absence of corporate advertising.

Note: Vertical axis shows the extent to which participants judged the product as 'exciting' (1-to-4-scale). The interaction effect was significant $\left(F(1,404)=6.15 ; p<0.05 ;\right.$ partial $\left.\eta^{2}=.015\right)$. 
An interaction effect was also found for the dependent variable 'social' $\left(F(1,404)=8.30 ; p<0.01 ;\right.$ partial $\left.\eta^{2}=.020\right)$, although opposite to that expected: a mean difference was evident in the high-involvement group, but the difference was close to zero in the low-involvement group. This unexpected result may reflect the fact that the two products presented to the participants differ in terms of the attitude dimension 'social'. The confectionery is generally seen as a family-oriented product. Perhaps in this case, even if the involvement is low, no heuristics, and hence no knowledge retrieval, are necessary to assess this product in the 'social' dimension. On the other hand, the tablet computer is a somewhat technical and 'cold' product, and is thereby difficult to assess in the 'social' dimension. Even if the product involvement was high, the participants needed heuristics when asked to what extent they considered the tablet as 'social'.

No interaction effects were found for the fourth dimension, 'emotional', and no differences were observed between the low- and high-involvement groups. Apparently, both groups were drawn to the delineated heuristic regardless of their involvement. Similar to what was expounded regarding the 'social' dimension, it was suspected that participants found it difficult to assess products in the 'emotional' dimension. This could be linked to the single items in this category that may not have been completely suitable for the task. Consequently, both the low- and high-involvement groups sought support to assess the product in terms of the 'emotional' dimension and therefore drew knowledge from the TV spots.

\section{Discussion}

While $\mathrm{H}_{1}$ was fully supported, $\mathrm{H}_{2}$ is only partially accepted. Above all, it is clear that corporate advertising affects consumer attitudes toward products manufactured by the company shown in the respective ad. In fact, consistent with the findings of Collins and Stevens (2002), the effects of advertising are not restricted to the target group, which in the case of corporate advertising can be, but is not limited to, the consumer. The present study furthers the work of Sheinin and Biehal (1999) because the participants were asked about their attitudes toward the products as opposed to the product ads.

Consistent with Keller and Edward's (1998) finding that image ads can influence purchase intentions and Kerr's (2003) assumption that a corporate ad campaign can affect sales, mostly positive shifts were found in the experimental group in terms of attitudes toward products. The interpretation that this shift leads to a higher willingness to buy is not far-fetched, but is beyond that supported by the positive effect of the stimulus on the 'attractiveness' dimension. Nevertheless, it must be kept in mind that participants were not asked about their purchase intentions, but rather for their attitudes toward the products. Further studies should examine the effects of corporate ads not only on attitudes, but also on purchase intentions or even concrete purchase decisions.

In line with Biehal and Sheinin (1998) and Biehal and Sheinin (2007) the present results suggest that a variety of factors influence the association between brand knowledge and knowledge drawn from corporate ads. Biehal and Sheinin suggest that the same processes by which these two kinds of knowledge influence each other should be further examined; however, little if any research has been done to explore these effects. This study answered their call for assessment of the role of customer involvement with the product; as a result, the existence of effects that verify $\mathrm{H}_{1}$ was confirmed. In addition, evidence that these effects are influenced by product involvement and therefore by the strength of elaboration was found. This became clear in the course of analyzing the data used to test $\mathrm{H}_{2}$, which assumed the influence of product involvement. Additional influencing factors, including the placement and size of retrieval cues (e.g., brand names and logos), parasocial interactions with and relationships to characters in the TV spot, the period of advertisement exposition, and elapsed time between watching the TV spot and assessing the product, can also be imagined; these should be systematically examined in future studies. In contrast to Biehal and Sheinin (2007), we asked the participants single products instead of a broader product portfolio. This was convenient on the one hand as the two single products differed clearly in terms of product involvement. On the other hand, it makes the generalization of the results harder.

The failure to confirm $\mathrm{H}_{2}$ might reflect the fact that the stimulus had a range of effects on the identified 'attitude' dimensions toward the product. Possible reasons for this, in terms of difficulties in judging the products in certain dimensions, are discussed above. Aside from this, it could be considered a weakness of the study design that even if the TV spots (stimuli) shared similar values, they were inevitably different. Future research should strive to control the content of the stimulus better or to analyze the content of the ads and incorporate the resulting data in the analysis of effects on the various dimensions of attitudes toward the products. Additionally, further research should incorporate the participants' previous knowledge about and attitudes towards the companies. We made sure that the participants did not know the advertisements but did not control for foreknowledge on the products or the companies. Other corporate advertisements or even product messages may have influenced the participants' judgements. As e.g. Sheinin and Biehal (2007) point out, a kind of "product-to-product spillover" (p. 22) may occur when participants are asked to assess a product they did not know until then. This means that participants could rely to their experiences with similar products of the same company (or even to similar products of competitor) as a knowledge source. The random assignment of participants to the groups in this study should have minimized the bias resulting from preexistent knowledge and attitudes but 
still, further research should try to control these factors.

Above all, upcoming research must clarify how trends in attitudes toward the products (i.e., whether they become more negative or more positive, which was not considered in this study), can be affected. A deeper look into the content of the stimulus would also be beneficial.

The study results should not be seen as representative of the general population because it was conducted as an online survey that allowed the participants to choose whether they would complete the questionnaire. In addition, the study design meant that the environment and other external influences that may have affected the participants' reception of the stimulation could not be controlled. These are typical sources of bias in online experiment designs (Groves, 2011; Wright, 2005) and thus need to be taken into account. Conducting a survey using this design was time- and cost-efficient, and resulted in a high number of completed questionnaires compared with an on-site design. It also facilitated the recruitment of participants, especially those for whom the computer and the Internet are key parts of their everyday lives (van Selm \& Jankowski, 2006). The advantages of this study design outweigh the disadvantages, and few difficulties arise as long as the interpretation of the results considers the limitations of the chosen design.

The findings of this study support the general assumption that corporate advertising can influence consumers' attitudes toward a company's products. There is evidence that the product involvement plays a role in the process of assessing a product under the influence of a corporate message. However, as there is no clear finding regarding this role, further research is required. Given the interesting findings of this study and their implications, as well as their limitations, continuing research into the phenomenon of corporate advertising and its effects is ongoing.

\section{References}

Belch, G. E., \& Belch, M. A. (2004). Advertising and promotion: An integrated marketing communications perspective. New York: McGraw-Hill.

Benedek, J., \& Miner, T. (2002). Measuring Desirability: New methods for evaluation in a usability lab setting. Retrieved from: http://www.microsoft.com/usability/UEPostings/DesirabilityToolkit.doc [02-16-16].

Biehal, G. J., \& Sheinin, D. A. (1998). Managing the brand in a corporate advertising environment: A decision-making framework for brand managers. Journal of Advertising, 27(2), 99-110. http://dx.doi.org/10.1080/00913367.1998.10673555

Biehal, G. J., \& Sheinin, D. A. (2007). The influence of corporate messages on the product portfolio. Journal of Marketing, 71(2), 12-25. http://dx.doi.org/10.1509/jmkg.71.2.12

Bobinski, G., \& Ramirez, G. (1994). Advertising to Investors: The Effect of Financial-Relations Advertising on Stock Volume and Price. Journal of Advertising, 23(4), 13-28. http://dx.doi.org/10.1080/00913367.1943.10673456

Broom, G. (2012). Cutlips and Center's Effective Public Relations. New York: Prentice Hall.

Brown, T., \& Dacin, P. (1997). The Company and the Product: Corporate Associations and Consumer Product Responses. Journal of Marketing, 61, 68-84. http://dx.doi.org/10.2307/1252190

Burgoon, M., Pfau, M., \& Birk, T. S. (1995). An Inoculation Theory Explanation for the Effects of Corporate Issue/Advocacy Advertising Campaigns. Communication Research, 22(4), 485-505. http://dx.doi.org/10.1177/009365095022004006

Cardona, M. (1998). Corporate-Ad Budgets at Record High: ANA Survey. Advertising Age, 69(17), 36.

Collins, C., \& Stevens, C. (2002). The relationship between early recruitment related activities and the application decisions of new labor-market entrants: a brand equity approach to recruitment. Journal of Applied Psychology, 87, 1121-1133. http://dx.doi.org/10.1037/0021-9010.87.6.1121

Crane, F. (1990). The Need for Corporate Advertising in the Financial Services Industry: a Case Study Illustration. Journal of Services Marketing, 4(2), 31-37. http://dx.doi.org/10.1108/EUM0000000002509

Fabrigar, L. R., Wegener, D. T., MacCallum, R. C., \& Strahan, E. J. (1999). Evaluating the use of exploratory factor analysis in psychological research. Psychological Methods, 4, 272-299. doi:10.1037/1082-989X.4.3.272

Frauscher, C., \& Signitzer, B. (1991). Unternehmenswerbung - Eine neue Form von Werbung setzt sich durch. [Corporate advertising. A new form of advertising asserts itself.]. Media Perspektiven, 5(1991), 291-296

Garbett, T. F. (1981). Corporate Advertising: The What, the Why, and the How. New York: McGraw-Hill.

Garbett, T. F. (1983). Researching Corporate Avertising. Journal of Advertising Research, 23, 1, 33-37.

Groves, R. (2011). Three Eras of Survey Research. Public Opinion Quarterly, 75(5), 861-871. http://dx.doi.org/10.1093/poq/nfr057 
Gürhan-Canli, Z., \& Batra, R. (2004). When corporate image affects product evaluations: The moderating role of perceived risk. Journal of marketing research, 4l(2), 197-205. http://dx.doi.org/10.1509/jmkr.41.2.197.28667

Haley, E. J. (1996). Exploring the Construct of Organization as Source: Consumers' Understandings of Organizational Sponsorship of Advocacy Advertising. Journal of Advertising, 25(2), 19-36. http://dx.doi.org/10.1080/00913367.1996.10673497

Ho, F. \& Hallahan, K. (2004). Post-earthquake communications in Taiwan: An examination of corporate advertising and strategy motives. Journal of Communication Management, 8(3), 291-306. http://dx.doi.org/10.1108/13632540410807709

Homer, P. (1990). The mediating role of attitude toward the ad. Some additional evidence. Journal of Marketing Research, 27, 78-86. http://dx.doi.org/10.2307/3172553

Hutcheson, G., \& Sofroniou, N. (1999). The multivariate social scientist. London: Sage.

Hwang, J. S., McMillan, S. J., \& Lee, G. (2003). Corporate web sites as advertising: An analysis of function, audience, and message strategy. Journal of Interactive Advertising, 3(2), 10-23. http://dx.doi.org/10.1080/15252019.2003.10722070

Javalgi, R., Taylor, M., Gross, A., \& Lampman, A. (1994). Awareness of Sponsorship and Corporate Image: An Empirical Investigation. Journal of Advertising, 23(4), 47-58.

Jørgensen, P., \& Isaksson, M. (2008). Building credibility in international banking and financial markets: A study of how corporate reputations are managed through image advertising. Corporate Communications, 13, 365-379. http://dx.doi.org/10.1108/13563280810914801

Keller, K. (1987). Memory Factors in Advertising: The Effect of Advertising Retrieval Cues on Brand Evaluations. Journal of Consumer Research, 14, 316-333. http://dx.doi.org/10.1086/209116

Keller, K. (2001). Building customer-based brand equity. Marketing management, 10(2), 14-21.

Kelly, K. J., \& Edwards, R. W. (1998). Image advertisements for alcohol products: Is their appeal associated with adolescents' intention to consume alcohol? Adolescence, 33(129), 47-60.

Kerr, D. (2003). Corporate advertising - does the public care? Admap, 38(7), 32-35.

Kim, S., \& Choi, S. M. (2014). Is Corporate Advertising Effective in a Crisis? The Effects of Crisis Type and Evaluative Tone of News Coverage. Journal of Promotion Management, 20, 97-114. http://dx.doi.org/10.1080/10496491.2013.872216

Kim, S., Haley, E., \& Koo, G. Y. (2009). Comparison of the paths from consumer involvement types to ad responses between corporate advertising and product advertising. Journal of Advertising, 38(3), 67-80. http://dx.doi.org/10.2753/JOA0091-3367380305

Kim, S., Haley, E., \& Lee, Y. J. (2008). Does consumers' product-related involvement matter when it comes to corporate ads? Journal of Current Issues \& Research in Advertising, 30(2), 37-48. http://dx.doi.org/10.1080/10641734.2008.10505246

Ledingham, J., \& Bruning, S. (1998). Relationship management in public relations: dimensions of an organization-public relationship. Public Relations Review, 24(1), 55-65. http://dx.doi.org/10.1016/S0363-8111(98)80020-9

MacKenzie, S., Lutz, R., \& Belch, G. (1986). The Role of Attitude Toward the Ad as a Mediator of Advertising Effectiveness: A Test of Competing Hypotheses. Journal of Marketing Research, 23, 130-143. http://dx.doi.org/10.2307/3151660

Marshall, J., \& Wise, R. (2013). The Resurgence of the Corporate Brand. Advertising Age, retrieved from http://adage.com/article/cmo-strategy/resurgence-corporate-brand/240855/ [02-16-2016]

McLeod, D., \& Kunita, M. (1994). A comparative analysis of the use of corporate advertising in the United States and Japan. International Journal of Advertising, 13, 137-137.

Pashupati, K., Arpan, L., \& Nikolaev, A. (2002). Corporate Advertising as Inoculation Against Negative News: An Experimental Investigation of Efficacy and Presentation Order Effects. Journal of Current Issues and Research in Advertising, 24(2), 1-15. http://dx.doi.org/10.1080/10641734.2002.10505131

Patti, C., \& McDonald, J. (1985). Corporate Advertising: Process, Practices and Perspectives (1970-1989). Journal of Advertising, 14(1), 42-49. http://dx.doi.org/10.1080/00913367.1985.10672929

Petty, R. E., \& Cacioppo, J. T. (1986). The Elaboration Likelihood Model of persuasion. Advances in Experimental 
Social Psychology, 19, 124-205. http://dx.doi.org/10.1016/S0065-2601(08)60214-2

Petty, R. E., Brinol, R., \& Priester, J. (2009). Mass Media Attitude Change. Implications of the Elaboration Likelihood Model of Persuasion. In J. Bryant \& M.B. Oliver, Media Effects. Advances in Theory and Research. New York: Routledge.

Rau, P., \& Preble, J. (1988). Corporate public issue advertising: an analysis of the attitudes of chief executives. International Journal of Advertising, 7(4), 293-306.

Rosengren, S., \& Bondesson, N. (2014). Consumer advertising as a signal of employer attractiveness. International Journal of Advertising, 33(2), 253-269. http://dx.doi.org/10.2501/IJA-33-2-253-269

Russell, D. W. (2002). In search of underlying dimensions: The use (and abuse) of factor analysis. Personality and Social Psychology Bulletin, 28, 1629-1646. http://dx.doi.org/10.1177/014616702237645

Schumann, D., Hathcote, J., \& West, S. (1991). Corporate Advertising in America: A Review of Published Studies On Use, Measurement, and Effectiveness. Journal of Advertising, 20(3), 35-56. http://dx.doi.org/10.1080/00913367.1991.10673346

Sethi, S. P. (1979). Institutional/image advertising and idea/issue advertising as marketing tools: Some public policy issues. Journal of Marketing, 43(1), 68-78.

Sheinin, D. A., \& Biehal, G. J. (1999). Corporate advertising pass-through onto the brand: Some experimental evidence. Marketing Letters, 10(1), 63-74. http://dx.doi.org/10.1023/A:1008087108223

Smith K., Smith, L., \& Dunbar, S. (2014). Using corporate advertising to improve public perception of energy companies. Journal of Strategic Marketing, 22(4), 347-356. http://dx.doi.org/10.1080/0965254X.2013.876080

Van Selm, M., \& Jankowski, N. (2006). Conducting Online Surveys. Quality \& Quantity, 40, 435-456. doi:10.1007/s11135-005-8081-8

Wilden, R., Gudergan, S., \& Lings, I. (2010). Employer branding: strategic implications for staff recruitment. Journal of Marketing Management, 26(1), 56-73. http://dx.doi.org/10.1080/02672570903577091

Winters, L. (1983). Comparing pretesting and posttesting of corporate advertising. Journal of Advertising Research, 23(1), 25-32.

Winters, L. (1986). The Effect of Brand Advertising on Company Image: Implications for Corporate Advertising. Journal of Advertising Research, 26(2), 54-59.

Wright, K. (2005). Researching Internet-Based Populations: Advantages and Disadvantages of Online Survey Research, Online Questionnaire Authoring Software Packages, and Web Survey Services. Journal of Computer - Mediated Communication, 10. http://dx.doi.org/10.1111/j.1083-6101.2005.tb00259.x

Zaichkowsky, J. L. (1985). Measuring the involvement construct. Journal of consumer research, 12, 341-352. http://dx.doi.org/10.1086/208520

\section{(cc) EY}

This work is licensed under a Creative Commons Attribution 3.0 License. 


\title{
Relationships among Job Satisfaction, Organizational Commitment, and Turnover Intention: Evidence from the Gambling Industry in Macau
}

\author{
Jen Hung Wang ${ }^{1}$, Kuan Chen Tsai ${ }^{2}$, Luo Jia Ru Lei ${ }^{1}$, Im Fan Chio ${ }^{1}$, Sut Kam Lai ${ }^{1}$ \\ ${ }^{1}$ School of Management, City University of Macau, Macau, China \\ ${ }^{2}$ Faculty of Humanities and Social Sciences, City University of Macau, Macau, China \\ Correspondence: Kuan Chen Tsai, Faculty of Humanities and Social Sciences, City University of Macau, Avenida Padre \\ Tomás Pereira Taipa, Macau, China
}

Received: January 4, 2016 Accepted: February 14, 2601 Online Published: February 22, 2016

doi:10.11114/bms.v2i1.1280

URL: http://dx.doi.org/10.11114/bms.v2i1.1280

\begin{abstract}
The purpose of this study was to examine the relationships among job satisfaction, organizational commitment, and turnover intention of workers in two casinos in Macau. The current study was a correlational study and used convenience sampling, and a total of 105 surveys were retrieved from employees working in two casinos in Macau. For our sample, we found that job satisfaction had a significant and positive correlation with organizational commitment. We also found that the association between job satisfaction and turnover intention was positive but not significant and the association between organizational commitment and turnover intention was negative but not significant. Finally, the regression model indicated that job satisfaction and organizational commitment were effective predictors of employees' turnover intention.
\end{abstract}

Keywords: job satisfaction, organizational commitment, turnover intention

\section{Introduction}

Employees are the type of capital most important capital to organizational survival (Short \& Harris, 2010). Huang and Hsiao (2007) found that the better the working conditions, the higher the levels of employees' organizational commitment - i.e., how strongly they want to be a part of the organization - and their job satisfaction. If people stay in one organization long enough to gain experience that benefits them in their efforts to obtain promotion and/or work of a more interesting nature, they will be more satisfied with their jobs and have stronger commitment to them (Meyer \& Allen, 1991). As such, how to improve employees' job satisfaction and organizational commitment and decrease employee turnover rates are vital issues for organizational development.

The gambling industry is the backbone of Macau's economy, and involves an estimated $25 \%$ of the working population (Chi \& Zheng, 2009). Demand for high-quality human resources is increasing in this industry. Consequently, the purpose of the current study was to examine the relationships among job satisfaction, organizational commitment, and turnover intention of workers in two casinos in Macau. In addition, the unique of this study was to help Macau government and gambling industry regulate necessary policies in order to cultivate employees' job environment being more friendly.

\section{Literature Review}

\subsection{Job Satisfaction}

Job satisfaction is neither completely contingent upon personality characteristics nor upon external working conditions; rather, it is an attitude and feeling formed by the interplay between individual personal factors and the environment (Hoppock, 1935; Vroom, 1964). For Locke (1969), job satisfaction depended on the discrepancy an individual perceived between her real possession and her expectations: if this discrepancy is small or nonexistent, then the individual will feel satisfaction, and if it is large, she will feel dissatisfaction. Following this line of argument, Wanous and Lawler (1972) declared that real possession has more, and longer-term, influence than expectations do. That is, the level of job satisfaction is determined by how employees define the discrepancy, and everyone will therefore have different perceptions of job satisfaction with regard to the same job. 
Scholars have varying perspectives on the relationship between job satisfaction and organizational commitment. Porter et al. (1974) pointed out that job satisfaction is an important component of organizational commitment, with the former being closely related to working environment and therefore more changeable than organizational commitment is. Because job satisfaction is characterized by instability and variability, it can be viewed as a causal factor vis-à-vis organizational commitment, with Currivan (2000) suggested that the higher people job satisfaction, the higher their organizational commitment. Williams and Hazer (1986) argue that organizational commitment is contingent upon the individual's assessment of perceived interest and suggested that job satisfaction is an antecedent of organizational commitment. Other empirical studies also show similar results (e.g., Kah Loong, 2011; Lambert, Hogan, \& Keena, 2015).

\subsection{Organizational Commitment}

Organizational commitment is a multi-factor construct (Cohen, 2003) for which scholars have proposed several competing typologies. For example, Staw (1978) classifies it into attitude commitment and behavior commitment. The former refers to people recognizing the goals and values of the organization and being willing to work hard to fulfill its mission; individuals anticipate the cost of leaving the organization because (e.g., status, pension, friendships with colleagues), and making psychological adjustments to maintain the consistency of their manners. For Meyer and Allen (1991), there are three kinds of organizational commitment: (a) emotional commitment, which refers to a person's attachment to a specific organization; (b) continuous commitment, a person staying in an organization because of his beliefs; and (c) normative commitment, a person staying within an organization out of a sense of responsibility or obligation.

Organizational commitment generally refers to the level of employees' loyalty, involvement, and recognition. For employees, the higher the organizational commitment, the closer the tie to the organizational vision and beliefs, and in turn the lower the tendency toward turnover (Sušanj \& Jakopec, 2012). Turnover refers to a broken relationship between employer and employee, regardless of which party causes it to happens (Ferguson \& Ferguson, 1986). Several studies have found a negative relationship between organizational commitment and turnover intention (Sarah \& Daniel, 2000; Sousa-Poza \& Henneberger, 2004; Timothy, 2000). Mobley, Horner, and Hollingsworth (1978) reported that organizational commitment has a more important effect on turnover intention than job satisfaction does. The greater a person's age and experience level, the higher the level of organizational commitment that they tend to have. When people stay in an organization for a lengthy period of time, they will invest more time and energy in it, so for those who are senior in the organization will be reluctant to leave their jobs and display higher levels of organizational commitment (Salancik, 1977).

\subsection{Turnover}

Turnover can be grouped into two types: voluntary turnover and involuntary turnover. The results from employees factors such as retirement, health issues, the continuation of education, and promotion, while the latter is caused by employers, and includes discharges and layoffs (Wanous, 1979). Turnover intention is the last stage of a series of withdrawal cognition processes undergone by dissatisfied employees, and has been viewed as an antecedent variable that predicts real leaving behavior (Iverson \& Deery, 1997; Lance, 1991).

The turnover process, as long as an interactive relationship between employees and employers is not expected, or the employee has a negative impression of the job they do, will cause the termination of this relationship, which in turn affects the organization, society, and economy to some extent. Consequently, it is expected that a high turnover of employees represents an obstacle to the quality of service provided by an organization and leads to negative effects on organizational performance.

A number of studies have revealed a negative connection between job satisfaction and turnover intention (Biswas, 2009; Karatepe et al., 2007; Yang, 2008). People with lower levels of job satisfaction are often uninterested in their jobs, and do not receive recognition from others.

\section{Method}

\subsection{Participants}

We used convenience sampling, and a total of 111 questionnaires were initially distributed to employees working in two casinos in Macau. In all, 105 valid copies were retrieved, 42 of them completed by males and 63 by females. A large majority of the respondents (69.5\%) were aged 35 or younger, with $39 \%$ aged 26 to 35. Most participants (72.4\%) had not been educated beyond high school, and $48.6 \%$ had 1-5 years of experience in this industry.

\subsection{Instrument and Procedure}

The survey used in the current study consisted of four parts: background information, job satisfaction, organizational 
commitment, and turnover intention. All survey items were answered via a six-point Likert scale, ranging from 1, "completely disagree" to 6, "completely agree." Background information included age, gender, education, and years of experience.

The section dealing with job satisfaction included 17 questions, of which eight were drawn from Chang (2010), four from Chiang (2005), and five from Zhang (2004). One sample item from this section was, "I have opportunities to work independently." Cronbach's $\alpha$ for the job-satisfaction items was .870 .

The section covering organizational commitment included 13 statements, of which six were adopted from Chung (2005), four from Lo (2009), and three from Hou (2008). One sample item from this part was, "I can fully develop my abilities while working in this organization." Cronbach's $\alpha$ for the organizational-commitment items was .907.

The part of the survey dealing with turnover intention comprised eight questions, all adopted from Huang (2007); for example, "If I leave, I will easily find a suitable position in another organization." Cronbach's $\alpha$ for the turnover-intention items was .844 , and for all 38 non-background items was .901 , indicating that the instrument has a good overall reliability.

\subsection{Data Analysis}

The current study was correlational in nature. In order to examine the relationships among the job satisfaction, organizational commitment, and turnover intentions of employees from two casinos in Macau, we first used Pearson correlation, followed by regression analysis to examine whether or not job satisfaction and organizational commitment were valid predictors of turnover intention. The prediction model treated job satisfaction and organizational commitment as independent variables, and turnover intention as the dependent variable. Finally, in order to examine the effects of employees' age and years of experience on job satisfaction, organizational commitment, and turnover intention, a series of two-way Analysis of Variance (ANOVA) were computed.

\section{Results}

\subsection{Correlations}

Table 1 presents means, standard deviations, and zero-order correlations among job satisfaction, organizational commitment, and turnover intention. The Spearman's rho coefficients reveal a significant and positive association between job satisfaction and organizational commitment $(r=.667, p<.01)$, while the association between job satisfaction and turnover intention was positive but not significant $(r=.069, p=.485)$. Finally, the association between organizational commitment and turnover intention was negative but not significant $(r=-.107, p=.275)$. We therefore accept H1a, as this correlation was strong, and partially accept H2a, in which the correlation was negative but weak, but not significant. However, we reject H3a because contrary to expectations, the correlation between job satisfaction and turnover intention was positive.

Table 1. Means, standard deviations, and intercorrelations among three measures

\begin{tabular}{llllll}
\hline \multicolumn{1}{c}{ Measure } & $M$ & $S D$ & 1 & 2 & 3 \\
\hline 1. Job satisfaction & 4.21 & .611 & -- & & \\
2. Organizational commitment & 4.08 & .737 & $.667 * *$ & - & - \\
3. Turnover intention & 4.21 & .753 & .069 & -.107 & - \\
\hline$* * p<.01$. & & & &
\end{tabular}

\subsection{Predictive Relationships}

Standard multiple regression was used to assess the relations between turnover intention as a criterion variable and organizational commitment and job satisfaction as predictor variables. The model indicates that $F(2,102)=4.71, p$ $=.011, R^{2}=.08$. In addition, as shown in Table 2 , organizational commitment $(\beta=.312)$ and job satisfaction $(\beta=-.406)$ were both valid predictors. For our sample, the more satisfied with her job a person is, the more likely she was to leave it; but the more committed to the organization she was, the lower her likelihood of leaving. These findings lead us to accept $\mathrm{H} 2 \mathrm{~b}$ and $\mathrm{H} 3 \mathrm{~b}$. Nevertheless, this model only accounts for $8 \%$ of variance in turnover intention.

Table 2. Regression analysis summary for two variables predicting turnover intention

\begin{tabular}{lccccc}
\hline \multicolumn{1}{c}{ Variable } & $B$ & $S E B$ & $\beta$ & $t$ & $p$ \\
\hline Job satisfaction & .385 & .164 & .312 & 2.35 & .021 \\
Organizational commitment & -.415 & .136 & -.406 & -3.05 & .003 \\
\hline
\end{tabular}

Note. $R^{2}=.08$

\subsection{The Influence of Age and Experience}

The results of our investigation using two-way ANOVA of the possible effects of age and years of experience on job satisfaction, organizational commitment, and turnover intention are presented in Tables 3, Table 4, and Table 5. Age and years of experience were coded as categorical variables, with four age groups being used (i.e., under 25, 26-35, 
36-45, and 46+). These four groups were further subdivided according to years of experience (under 1, 1-5, 6-10, and $11+)$. Table 3 shows that age did not produce a significant main effect with respect to job satisfaction, $F(3,94)=.221$, $p=.882$. A non-significant main effect was founded for years of experience, $F(3,94)=.053, p=.984$. A non-significant interaction effect between age and years of experience, $F(4,94)=1.591, p=.183$, was also observed.

Table 4 presents the relationships of the respondents' ages and years of experience to their levels of organizational commitment. Again, neither age $(F(3,94)=.518, p=.671)$ nor years of experience $(F(3,94)=.057, p=.982)$ had significant main effects, nor did they produce a significant interaction effect with organizational commitment $(F(4,94)$ $=.706, p=.590$ ).

With regard to the effects of age and years of experience on turnover intention, Table 5 shows that the two independent variables produced non-significant main effects (age: $F(3,94)=2.405, p=.072$; years of experience: $F(3,94)=.312$, $p=.817)$, and that their interaction was also not significant, $F(4,94)=.723, p=.579$. Based on these observations, we must reject $\mathrm{H} 1 \mathrm{~b}, \mathrm{H} 2 \mathrm{c}$, and $\mathrm{H} 3 \mathrm{c}$.

Table 3. Summary table for two-way analysis of variance of the effects of age and experience on job satisfaction

\begin{tabular}{lcccccc}
\hline \multicolumn{1}{c}{ Source } & $d f$ & $S S$ & $M S$ & $F$ & $p$ & $\eta^{2}$ \\
\hline Age & 3 & .242 & .081 & .221 & .882 & .007 \\
Experience & 3 & .058 & .019 & .053 & .984 & .002 \\
Age x Experience & 4 & 2.326 & .582 & 1.591 & .183 & .063 \\
Within cells & 94 & 34.353 & .365 & & & \\
Total & 105 & 1899.412 & & & & \\
\hline
\end{tabular}

Table 4. Summary table for two-way analysis of variance of the effects of age and experience on organizational commitment

\begin{tabular}{lcccccc}
\hline \multicolumn{1}{c}{ Source } & $d f$ & $S S$ & $M S$ & $F$ & $p$ & $\eta^{2}$ \\
\hline Age & 3 & .840 & .280 & .518 & .671 & .016 \\
Experience & 3 & .093 & .031 & .057 & .982 & .002 \\
Age x Experience & 4 & 1.527 & .382 & .706 & .590 & .029 \\
Within cells & 94 & 50.843 & .541 & & & \\
Total & 105 & 1806.716 & & & & \\
\hline
\end{tabular}

Table 5. Summary table for two-way analysis of variance of the effects of age and experience on turnover intention

\begin{tabular}{lcccccc}
\hline \multicolumn{1}{c}{ Source } & $d f$ & $S S$ & $M S$ & $F$ & $p$ & $\eta^{2}$ \\
\hline Age & 3 & 3.598 & 1.199 & 2.405 & .072 & .071 \\
Experience & 3 & .466 & .155 & .312 & .817 & .010 \\
Age x Experience & 4 & 1.441 & .360 & .723 & .579 & .030 \\
Within cells & 94 & 46.870 & .499 & & & \\
Total & 105 & 1923.813 & & & & \\
\hline
\end{tabular}

\section{Discussion}

For our sample, job satisfaction had a significant and positive relationship with organizational commitment, and this correlation was strong $(r=.701)$. This finding is in line with previous studies' suggestions that the more satisfied employees are with their jobs, the greater their commitment to their organization will be (Baranik, Rolling, \& Eby, 2010; Lim, 2010). However, the results did not fully support our hypothesis that organizational commitment will have a significant and negative relationship on turnover intention: we did find a negative association $(r=-.187)$, but it was not significant. It should be noted in this context that the majority of our participants (48.6\%) had between one and five years of experience, and thus might not have developed a strong organizational commitment.

We also found that the more satisfied our respondents said they were with their current jobs, the more likely they were to report planning to leave. This unexpected finding contradicts the previous literature. One possible explanation is that, as Carsteon and Spector (1987) suggested, the availability of job opportunities is an important reason for turnover. Because Macau has abundance of job openings in the gambling industry, it is relatively easy to find an equivalent or even a higher-paid job at a different casino. Even people who are satisfied with their current positions, if they have a chance to receive a higher salary elsewhere, are reasonably likely to leave their organizations.

It should also be taken into consideration that the gambling industry is perhaps uniquely profit-driven, so job satisfaction may not have a direct impact on turnover intention. In addition, the industry in Macau operates on a three-shift system, which may lead employees with high levels of job satisfaction and organizational commitment to nevertheless leave their organizations because their shift schedules are detrimental to their physical wellness and/or interfere with family responsibilities.

When we examined the extent to which job satisfaction and organizational commitment can impact employees' turnover intention, the regression model indicated that both variables were effective predictors. The higher the organizational commitment, the lower the turnover intention $(\beta=-.406)$; however, the greater the job satisfaction, the 
higher the turnover intention $(\beta=.312$ ). As previously discussed, unique features of the gambling industry render the relationship between job satisfaction and turnover intention complicated and far from crystal clear. Additionally, the current study's regression model accounts for a mere $8 \%$ of total variance in turnover intention. This result suggests that other factors may be more important in driving turnover intention, and carries useful implications for other researchers investigating the gambling industry.

With regard to the interaction of age and years of experience with job satisfaction, organizational commitment, and turnover intention, our ANOVA analyses found neither main nor interaction effects. In other words, it was not possible to identify significant differences between age groups or between groups based on years of experience.

\section{Limitations and Possible Future Directions}

When interpreting the results of this study, it should be remembered that only two casinos were involved. For the results to be generalizable, a larger sample size including employees from a larger number of casinos would need to be studied. For example, future researchers might conduct cross-cultural studies, examining employees' attitudes toward the casino industry in Macau, Singapore, and the United States. Another possible issue is that participants may have been in a state of fatigue when responding the survey: even though the instrument contained only 38 simple statements, the unique pressures of their working environment may have meant that they did not have an appropriate amount of time in which to respond to it. Future researchers should consider better methods of distributing surveys to this unusual group. Finally, the current study was a correlational study, which might affect its empirical validity. Including more variables and using covariate techniques to control confounding variables are promising avenues for future study.

\section{Conclusion}

In our study, we found that employees in Macau gambling industry their job satisfaction had a significant and positive relationship with organizational commitment. Organizational commitment had a negative but not significant correlation with turnover intention. Finally, the correlation between job satisfaction and turnover intention was positive but not significant. Based on the regression model, we also found that employees' organizational commitment and job satisfaction can predict their turnover intention. In addition, people's age and experience did not have an influence on their job satisfaction, on their levels of organizational commitment, and on their turnover intention.

The unique contribution of the current study was that, when we examined employees' attitudes toward two casinos in Macau, a positive relationship was found between job satisfaction and organizational commitment, and a positive relationship was found between job satisfaction and turnover intention. It would be expected, both based on the prior literature and intuitively, that a negative relationship between job satisfaction and turnover intention would be found, but we obtained the opposite result. This may have resulted from three causes: that the unemployment rate in Macau is very low, at $1.8 \%$ (Statistics and Census Service, 2015); that salary may be an unusually or disproportionately major consideration for Macau casino employees; and that job opportunities in the gambling industry are abundant and easy to move between.

A number of our participants mentioned that opportunities for promotion in the casinos were rare, and usually based on certain number of years of experience, leading many employees to job-hop in search of higher salaries. It seems that, at least in this particular context, organizational commitment is not a high priority in career development. As far as education is concerned, the majority of employees have only high school diplomas, and consider that this disadvantages them in any job market other than the gambling industry.

Taken as a whole, our research carries several implications for the gambling industry in Macau. First, in order to understand employees' perceptions of their working environment, it is recommended that employee opinion surveys be distributed routinely, and the data thus gathered used as a basis for future corporate policymaking. Second, organizations should provide a sound welfare system and set up bonus schemes to lessen turnover rates. Finally, education and training programs are needed, especially for less experienced workers, to assist them to develop career plans. For example, a casino could work with local universities to provide its employees with a chance of obtaining higher-education diplomas, thereby improving the quality of its own human resources as well as the employees' overall career prospects.

\section{References}

Anderson, C. A., Gentile, D. A., \& Buckley, K. E. (2007). Violent video game effects on children and adolescents: Theory, research and public policy. http://dx.doi.org/10.1093/acprof:oso/9780195309836.001.0001

Baranik, L. E., Rolling, E. A., \& Eby, L. T. (2010). Why does mentoring work? The role of perceived organizational support. Journal of Vocational Behavior, 76(3), 366-373. http://dx.doi.org/10.1016/j.jvb.2009.07.004

Biswas, S. (2009). Job satisfaction and job involvement as mediators of the relationship between psychological climate 
and turnover intention. South Asian Journal of Management, 16, 27-43.

Carsten, J. M., \& Spector, P. E. (1987). Unemployment, job satisfaction, and employee turnover: A meta-analytic test of the Muchinsky model. Journal of Applied Psychology, 72, 374-381. http://dx.doi.org/10.1037/0021-9010.72.3.374

Chang, Y. P. (2010). Short-term employment in work attitude and job performance study: A case study of Miaoli county elementary and junior high school. Unpublished Master's Thesis, http://handle.ncl.edu.tw/11296/ndltd/05570496529780760993

Chi, S. S., \& Zheng, G. (2009). Drivers of job satisfaction as related to work performance on Macao casino hotels: An investigation based on employee survey. International Journal of Contemporary Hospitality Management, 21(5), 561-578. http://dx.doi.org/10.1108/09596110910967809

Chiang, H. C. (2005). A study of leadership behaviors of manager and job characteristics on job satisfaction and organizational commitment of employee: A case study of banks in Tainan. Unpublished Master's Thesis, http://handle.ncl.edu.tw/11296/ndltd/54027885646580021230

Chung, W. L. (2005). The relationship among job satisfaction, organizational commitment, job search, and turnover intention of flight attendant: A case study of an airline in Taiwan. Unpublished Master's Thesis, http://handle.ncl.edu.tw/11296/ndltd/73483761478696068955

Cohen, A. (2003). Multiple commitments in the workplace: An integrative approach. Hillside, NJ: Erlbaum.

Currivan, D. B. (2000). The causal order of job satisfaction and organizational commitment in models of employee turnover. Human Resource Management Review, 9(4), 495-524. http://dx.doi.org/10.1016/S1053-4822(99)00031-5

Ferguson, G. H., \& Ferguson, W. F. (1986). Distinguishing voluntary from involuntary nurse turnover. Nursing Management, 17(12), 43-44. http://dx.doi.org/10.1097/00006247-198612000-00018

Hoppock, R. (1935). Job satisfaction. New York, NY: Harper.

Hou, W. J. (2008). The effect of pay satisfaction and pay equity on the engineer work attitude. Unpublished Master's Thesis, available at http://handle.ncl.edu.tw/11296/ndltd/66293396805608438061

Huang, H. H. (2007). The relationships between job satisfaction and turnover intention of care workers in welfare institutions for the Unsabled. Master's Thesis, http://handle.ncl.edu.tw/11296/ndltd/20006122593489799898

Huang, T. C., \& Hsiao, W. J. (2007). The causal relationship between job satisfaction and organization commitment. Social Behavior and Personality, 35(9), 1265-1276. http://dx.doi.org/10.2224/sbp.2007.35.9.1265

Iverson, R. D., \& Deery, M. (1997). Turnover culture in the hospitality industry. Human Resource Management Journal, 7(4), 71-82. http://dx.doi.org/10.1111/j.1748-8583.1997.tb00290.x

Kah, L. L. (2011). The organizational commitment: The study of mentoring and leader-member exchange (LMX) among auditors in Malaysia-moderating effects of gender. International Journal of Interdisciplinary Social Sciences, 6, 123-146.

Karatepe, O. M., Yavas, U., \& Babakus, E. (2007). The effects of customer orientation and job resources on frontline employees' job outcomes services. Marketing Quarterly, 29, 61-79. http://dx.doi.org/10.1300/J396v29n01_04

Lambert, E. G., Hogan, N. L., \& Keena, L. D. (2015). The impact of job attitudes on private correctional staff's continuance and affective organizational commitment. Journal of Applied Security Research,10, 1-22. http://dx.doi.org/10.1080/19361610.2015.972260

Lance, C. E. (1991). Evaluation of a structural model relating job satisfaction, organizational commitment, and precursors to voluntary turnover. Multivariate Behavioral Research, 26, 137-162. http://dx.doi.org/10.1207/s15327906mbr2601_7

Lim, T. (2010). Relationships among organizational commitment, job satisfaction, and learning organization culture in one Korean private organization. Asia Pacific Education Review, 11(3), 311-320. http://dx.doi.org/10.1007/s12564-010-9087-z

Lo, C. W. (2009). The impact of airlines organizational culture and commitment on service quality. Unpublished Master's Thesis, http://handle.ncl.edu.tw/11296/ndltd/50795780906299490546

Locke, E. A. (1969). What is job satisfaction? Organizational Behavior and Human Performance, 4, $309-336$. http://dx.doi.org/10.1016/0030-5073(69)90013-0

Meyer, J. P., \& Allen, N. J. (1991). A three-component conceptualization of organizational commitment. Human 
Resource Management Review, 1, 61-89. http://dx.doi.org/10.1016/1053-4822(91)90011-Z

Mobley, W. H., Horner, S. O., \& Hollingsworth, A. T. (1978). An evaluation of precursors of hospital employee turnover. Journal of Applied Psychology, 63(4), 408-414. http://dx.doi.org/10.1037/0021-9010.63.4.408

Porter, L. W., Steers, R. M., Mowday, R. T., \& Boulian, N. (1974). Organizational commitment, job satisfaction, and turnover among psychiatric technicians. Journal of Applied Psychology, 59(5), 603-609. http://dx.doi.org/10.1037/h0037335

Salancik, G. R. (1977). Commitment and the control of organizational behavior and belief. In Staw, B. W. \& Salancik, G. R. (Eds.), New Directions in Organizational Behavior (pp. 1-54). Chicago, IL: St. Clair.

Sarah, L. B., \& Daniel, S. J. (2000). Organizational socialization in the host country: The missing link in reducing expatriate turnover. International Journal of Organizational Analysis, 8(4), 380-400. http://dx.doi.org/10.1108/eb028924

Short, T., \& Harris, R. (2010). Challenges in aligning workplace learning with business goals: A perspective from HRD professionals in New Zealand. Australian Journal of Adult Learning, 50(2), 358-386.

Sousa-Poza, A., \& Henneberger, F. (2004). Analyzing job mobility with job turnover intentions: An international comparative study. Journal of Economic, 8, 113-137. http://dx.doi.org/10.1080/00213624.2004.11506667

Statistics and Census Service (2015). Principal indicators. http://www.dsec.gov.mo/default.aspx?lang=en-US

Staw, B. M. (1978). Commitment to a policy decision: A multi-theoretical perspective. Administrative Science Quarterly, 23, 40-64. http://dx.doi.org/10.2307/2392433

Sušanj, Z., \& Jakopec A. (2012). Fairness perceptions and job satisfaction as mediators of the relationship between leadership style and organizational commitment. Psychological Topics, 21(3), 509-526.

Timothy, F. J. (2000). Socialization and organizational outcomes in large public accounting firms. Journal of Managerial Issues, 12, 13-33.

Vroom, V. H. (1964).Work and motivation. New York, NY: John Wiley \& Sons.

Wanous, J. P. (1979). Job survival of new employee. Personnel Psychology, 32(4), 651-662. http://dx.doi.org/10.1111/j.1744-6570.1979.tb02338.x

Wanous, J., \& Lawler, E. E. (1972). Measurement and meaning of job satisfaction. Journal of Applied Psychology, 56, 95-105. http://dx.doi.org/10.1037/h0032664

Williams, L. J., \& Hazer, J. R. (1986). Antecedents and consequences of satisfaction and commitment in turnover models: A reanalysis using latent variable structural equation methods. Journal of Applied psychology, 71(2), 219-231. http://dx.doi.org/10.1037/0021-9010.71.2.219

Yang, J. T. (2008). Effect of newcomer socialization on organizational commitment, job satisfaction, and turnover intention in the hotel industry. Journal of Service Industries, 28(4), 429-443. http://dx.doi.org/10.1080/02642060801917430

Zhang, S. H. (2004). A study of the personality traits, job satisfaction, and tendencies in turnover of temporary post-secondary school employees. Unpublished Master's Thesis, http://handle.ncl.edu.tw/11296/ndltd/79817623516218551915

This work is licensed under a Creative Commons Attribution 3.0 License. 


\title{
Resolving Tensions among Creative Departments through Brand Identity Definition: The Case Study of Pininfarina
}

\author{
Gérald Mazzalovo \\ Correspondence: Gérald Mazzalovo, Brand specialist, Member of the Center for Engaged Management Research \\ (CEMR) at Paris-Dauphine University, France
}

\author{
Received: January 15, 2016 Accepted: February 1, 2016 Online Published: February 26, 2016 \\ doi:10.11114/bms.v2i1.1414 \\ URL: http://dx.doi.org/10.11114/bms.v2i1.1414
}

\begin{abstract}
In 2007, the famous Italian car design firm Pininfarina decided to develop its own mono-branded finished goods business. The jump from exclusively B2B activities to B2C was a major strategic move. The project initiated with the formalization of a possible brand identity as being the necessary preliminary exercise. Through the study of all the design activities over 80 years of history and following a semiotic approach, brand aesthetics and ethics invariants were identified.

Four different design teams were involved in the project and 5 main findings were identified in the course of the project:

Tensions exist among the various design teams because of the lack of coherence in design and each pretends to interpret the brand in a more consistent way

The creative teams feel the need for a well-defined and formalized brand identity, providing some missing common creative guidelines characterizing he brand

The design teams participated actively and enthusiastically to the process of brand identity definition

The President's positive attitude towards the project and his direct involvement have been essential in the project success

The tensions among the design teams have decreased by the brand identity definition process and results

The study had direct academic and operational implications:

It proved the validity of the semiotic approach to the formalization of brand identity

A diagnostic tool was created to measure the degree of consistency of any designed brand manifestation (car, advertising, architecture, car show installations...) with respect to the defined brand ethics and aesthetics.

Finally, Pininfarina presented a special concept car (Sintesi) at the Geneva car show in 2008 that integrated all the elements of the newly defined brand identity.
\end{abstract}

Keywords: designer, brand identity, semiotics, tensions reduction

\section{Introduction}

In December 2006, Andrea Pininfarina (AP), President and CEO of one of the oldest and worldwide leading Italian car design firm invited a few brand specialists to a meeting at the company's headquarters in Cambiano (a town in the Province of Turin in the Italian region) in order to explore the possibilities to develop the brand of Pininfarina. He started the meeting declaring: "I want to make money with my brand, just as Ferrari is doing with his." At that time, Pininfarina had never designed and sold mono-branded products under its own brand. This was the starting of a consultancy project, which started with the definition and formalization of the Pininfarina possible brand identity and concluded in 2008, with a detailed business plan to launch mono-branded products and services.

In this particular context of a project intended to develop "Business to Consumer" (B2C) activities for a product Designer exclusively servicing other brands, this paper shows how the definition of the brand identity helps to reduce

\footnotetext{
${ }^{1}$ In 2006, Ferrari was already invoicing more with derivative objects (Clothing, accessories, books, games, etc.) than with the approximately 6000 cars sold yearly.
} 
existing pressures among the creative, business and engineering sensibilities (Chiapello, 1998; Johansson \& Holm, 2006; Michlewski, 2008).

\subsection{A Brief History of Pininfarina ${ }^{2}$}

Battista "Pinin" Farina was born in Turin during 1893. He began to work at age 11, in his older brother's car body shop. He founded Carrozzeria Pinin Farina in 1930 in order to design, engineer and assemble cars. It is the beginning of a long story of car design and development for most of the famous car brands: Alfa Romeo, Ferrari, Fiat, Lancia, Maserati, Peugeot, Cadillac, GM, Bentley, Volvo, Mercedes, etc. and now the Chinese brands such as AviChina, Chery, Changfeng, Brilliance and JAC. The privileged relationship with Ferrari has marked both firms history. During the period of 1950s to 2014, all of the Ferrari cars (except one by Bertone) have been designed by Pininfarina. The current President is Paolo Pininfarina, grandson of the founder. In 2006 the company is experiencing a restructuration of its activities. A manufacturing site has been closed and the group is refocusing on "industrial design, sustainable mobility and extracting value from the brand". The company has evolved from a car body-maker ${ }^{3}$ to a company involved in design, engineering and niche manufacturing for third-party companies. It is a service company active into a B2B environment.

Adding a mono-branded business targeted to the consumer market to the traditional B2B activities is a case of business diversification (Stern \& Henderson, 2004) as well as brand extension (Monga \& John, 2010). This is indeed very similar to what Ferrari did, when it started developing its derivative business in the early period of 2000: New products for new consumers. Pininfarina can be categorized as a designer brand (C.M. Moore, J. Fernie \& $\underline{S}$ Burt, 2000), but not exactly in the sense used for the fashion designers as it is exclusively active in a context of B2B environment. However, it meets all the requirements of a brand as defined by Lendrevie, (2009): it has a name, characteristic signs (logo, calligraphy...) and it can trigger emotions and mental representations with its customers ${ }^{4}$. What makes this desired transformation particularly relevant to the brand specialists is the fact that so far, Pininfarina has designed models for other companies and therefore acted essentially as the interpreter of someone else identity.

\subsection{Organization of the Design Function in Pininfarina}

As most of the leading traditional Italian car body-makers (Bertone, Giugiaro...), Pininfarina offers a full range of services from conception, design, engineering and manufacturing of cars. Its manufacturing and engineering competencies directly contribute to its design capability which in any case remains the foundation of the company reputation. The five Directors report to the President: Design, Image and Communication, Corporate Finance, the Centre of Aerodynamic and Acoustic Research and the General Manager who has the responsibility for Production, Engineering, Human Resources and Commercial activities.

The three Chief Designers report to The Design Director. The distribution of specific projects to each team is based on the skills and history of each of them. The team specialized by clients (Ferrari, Lancia, Peugeot, and Chinese car companies), car typology (Concept car, convertible, sedan, trucks), or specific parts (interior or exterior), etc. The team is composed of 6 to 7 car designers led by a design team leader (See Figure 1).

\footnotetext{
${ }^{2}$ Source: www.pininfarina.com [accessed August $15^{\text {th }} 2014$ ]

3 "Carozziere" in Italian is also translated as Coachbuilder (source: Carrozzieri Italiani 2008, published by ANFIA. Associazione Nazionale Filiera Industria Automobilistica.)

${ }^{4}$ A good demonstration of the emotions that the cars designed by Pininfarina can generate may be found in the proliferation of the clubs of owners of the Peugeot 406 Coupe. Almost 110000 cars were sold from 1996 till 2004. They still generate enthusiasm with their owners (refer to the sites www.406coupeclub.org for UK, www.clubcoupe406.net for France and many Internet forums).
} 


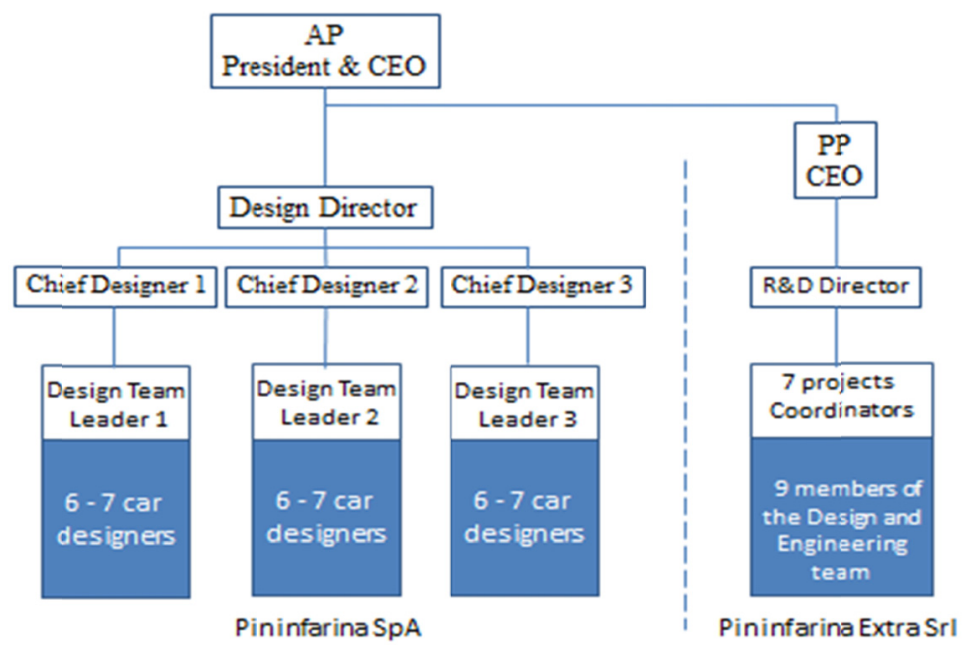

Figure 1. Pininfarina Schematic Design Organization (2007)

Pininfarina Extra $\mathrm{Srl}$ is a fully owned subsidiary created to develop design services for projects not related to the automotive industry (EXTRA: EXcept TRAnsport). Under the R\&D (Research and Development) Director there are 7 Project Coordinators and 9 members of the Design and Engineering team. He reports to the CEO (Paolo Pininfarina (PF), Andrea's brother).

We can therefore consider that we have 4 designing teams ( 3 automotive and 1 Extra) which work separately on specific projects. No specific training is planned for the newly hired designers. In the same way as the painting workshops of the renaissance painters were organized (Janson, 1995), the newly hired team learn by observing and participating in the projects, initially being involved in minor works and then progressively allowed into increasing amounts of creative participation through the recognition by his peers and team leaders of his capacities to contribute creatively and adequately to the projects.

\section{Methodology}

The study is based on a consultancy assignment resulting from a request from AP in 2007 to improve the financial results of the company through the conception, design and commercialization of Pininfarina mono-branded products. One of the paper's co-author led the consulting assignment. A process-focused qualitative case study design was selected (Eisenhardt, 1989; Langley, 2011) in order to concentrate on the change process which led to a reduction of the pressures, stress and tensions among the design departments. Koch (2014) quotes Dawson (2012) for a definition of process research as a "... real time study of changes as-it-happens over time defining the process research through the observed, documented and lived experiences of people as they seek to make sense and give sense individually and collectively to decision and non-decision making activities."

This was an ideal opportunity to apply the principles of process-focused qualitative research as through interviews of the main actors, their involvement in the definition and formalization of the Brand Identity and their consequential utilization of the results, we were able to observe and documents live experiences and changes of attitudes over time.

This article is also an example of Engaged Management Research design as supported by Van de Ven, (2007) who wrote that "Engaged scholarship is a participative form of research for obtaining the advice and perspectives of key stakeholders." In our case the stakeholders involved are some of the owners (AP and PP), the management, the designers and the researchers.

\subsection{Project Description}

The project team was composed of 3 consultants and the Communication and Image Director who functioned as the key interface for the internal project organization. PP served as Special Counsel to the team, in order to make sure that the point of view of the Extra team would be taken into account.

Regular reporting was made to AP during the 3 months of the first phase of the project.

The consultancy assignment required gaining the support of the several design teams. One way to ensure this support has been the inclusion in the project team, as one of the 3 consultants, of an external professional designer who through his intimate knowledge of the car design world, would contribute to gaining respect from the interlocutors and ensure the use of a proper tone and vocabulary in the interviews and questionnaires.

The corpus was made of pictures of cars and other objects designed since 1930, car shows stands designs, advertising 
campaigns, books [including the founder's biography, (1968)], architecture concepts of the headquarters and of the 3 assembly sites, specialized websites as well as financial reports, organograms, markets' data, customers, competition and design trends, press articles, etc.

Data were also gathered through 25 inside interviews (mainly of designers), guided by open questionnaires. We also performed some interviews outside the firm with Executives of Design institutions in Turin.

The project was structured into 2 main phases with the following objectives (See Figure 2):

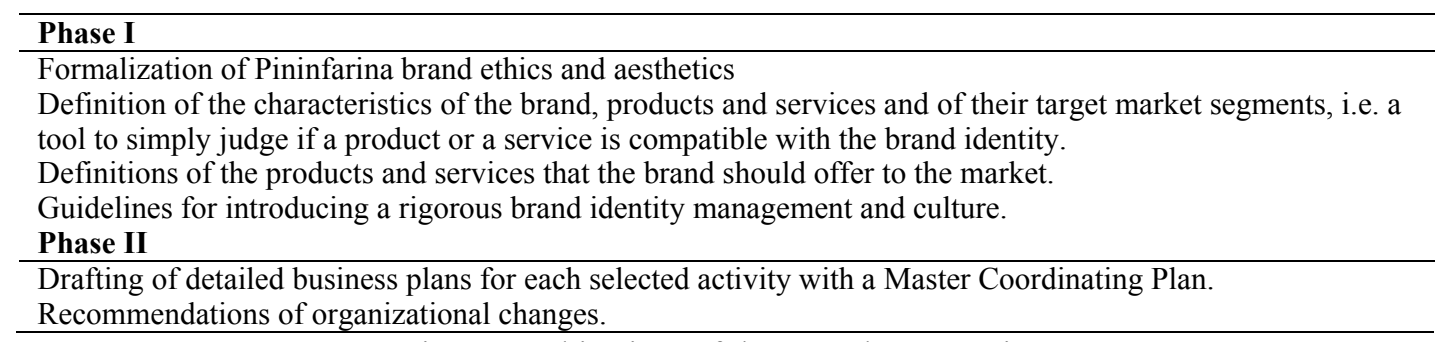

Figure 2. Objectives of the consultancy project

\subsection{Brand Identity}

The first objective of phase 1 was the formalization of the brand identity. We considered that at a time of developing mono-branded products, the formalization of Pininfarina brand identity was not only a significantly important reflexion process but also the first necessary methodological step. So far, the brand management logics were not really developed at Pininfarina; deciding to go after the B2C market with mono-branded products made the need for brand management unavoidable.

The identity-based brand management approach has developed strong support since early 1990's (Kapferer, 1992; Upshaw, 1995; Aaker, 1996; de Chernatony, 2006). According to Burmann and Al, (2009) consider the notion of brand identity as the theoretical basis of their brand equity model. As per the O'Shaughnessy, (1987) is quoted by Burmann and Al, (2009) as stating that: "Brand identity constitutes a necessary condition for maintaining buyer's trust, which in turn is the basis for long-term customer relationship and brand loyalty."

We also consider (Chevalier \& Mazzalovo, 2004 and 2012; Mazzalovo, 2012), as per the findings of these studies are going to confirm that a clearly formalized brand identity is a major federating tool for all the creative and communicating departments, ensuring a strong coherence in all of the brand manifestations.

The last reason which led us to choose to start the project by a brand identity definition is due to the fact that the identity issues are at the heart of the nature of the design activities. The designer needs to constantly resolve the dilemma existing between the brand own identity and his own "point of view". As he is supposed to interpret the clients brand identity without renouncing his own. Ferrari, like Peugeot, comes to Pininfarina for its specific way of designing cars, for its unique interpretation of their brand within the context of a particular project. Haute Couture and Ready-to-Wear, because many designers work both on a brand collection as well as on their own, offer various examples on how the identity dilemma is resolved. In general, Couturiers are either good interpreters of the brand they design for, or strong designer of their own brand. Karl Lagerfeld is a virtuoso interpreter of Chanel. The collection he markets under his own name has never known a great recognition. We could say the same for Galliano when he was designing Dior collections, whereas Narcisso Rodriguez has experienced better success with his own collections than for his work for Loewe in the late 1990's.

Theoretically, the formulation of Pininfarina own brand identity was developed using Floch's semiotic approach (1990 and 1995). Floch was a leading member of what has been called l'Ecole de Paris (Coquet, 1982), or the school of narrative semiotics (Groupe $\mu$, 1992) rooted in structuralist teachings of Greimas in the 1970's. Floch's brand identity scheme is based on Saussure's (1916) approach to sign (signifier and signified), then taken up by Hjelmslev, (1971). Floch's contribution is his focus on the invariant parts of the 2 levels of expression and content, in line also with Ricoeur's, (1990) notion of narrative identity. The scheme, later on called the brand identity hinge, has been taken up to illustrate specific brand issues by Heilbrunn, (2000); Semprini (1992 and 2005); Chevalier \& Mazzalovo, (2004 and 2012) and Mazzalovo \& Darpy, (2014) fundamental hypothesis of all the researchers who use the semiotic approach to brand identity is that brands need to produce meaning in order to be competitive.

\section{Findings}

Five key and interrelated findings were put as evidence:

1) Existence of Tensions Among the Design Teams 
There is a widespread feeling within the organization that the recent Pinifarina design projects may not have been as characteristic and homogeneously focused as before. Design team leader (3) declares: "In the past 15 years, our designs have been less coherent than before". The Deputy Communication Director is even more explicit: "In the past car body-makers used to have both the eye and the hand... I have sometimes the impression that we are left with the hand, how to recuperate the eye?"

This lack of coherence in design triggers tensions among the design teams. They respectively feel that they understand and interpret Pininfarina brand better, as expressed (very often with caution) in some interviews. Critics on design coherence focus primarily on the extra non-automotive design projects:

"Extra is designing beautiful objects... however not necessarily Pininfarina (Design Team Leader 3)

"There is a lot of heterogeneity in the non-automotive designs... It is pointless to try to systematically apply automotive lines and shapes to non-automotive products."

"I do not know them (Extra) well... we are very much apart." (Design Director)

"The Extra contract with Keating to design a hotel in California should have been managed more rigorously. The Ferrari red which has been used in the decoration is not a characteristic of Pininfarina."

"The small objects (Extra) are often over-designed."

"The design of the jet interior reflects ostentatious, old luxury, without soul."

"There is no common vision between Extra and the car design teams yet what is the difference between a car and a jet plane interior design?" (Deputy Communication Director).

"In their field (Extra), you can design without being a specialist and therefore perhaps being more innovative. However, beware of gratuitous design." (Chief Designer 3)

"The contracts of Extra with its clients do not include clauses related to Pininfarina image (e.g. Snaidero)." (Communication and Image Director).

"There is a gap between the worlds of Car Design and Extra."

"Extra has the tendency to transfer a specific car design language into other objects."(Director of a Turin Design School)

\section{These perceptions are also shared by some Extra's employees:}

"Certain objects have been overdesigned (divani Nieri) and certain projects insufficiently controlled (Keating hotel)." (Extra R\&D Director)

These tensions are often expressed as a lack of communication among the design teams:

"There is an iron curtain in between the design departments." (Extra Commercial Director)

"It is a pity we do not work more together" (Chief Designer)

These communication difficulties among creative departments are reinforced by the professional project secrecy that the nature of the design work imposes as the Director of Communication and Image recognizes it: "The culture of secret creates difficulties for the communication department." It naturally affects also the rapports among the various design teams.

The organizational tensions go beyond the realm of the design departments. A few comments relate to the rapports Design has with the Engineering department:

"We are not integrated enough with the engineering."

"Even engineers need to have that sensibility... They are not very creative." (Design Team Leader 3)

"Engineers are not creative enough" (Head Designer for special projects)

\section{2) The Creative Team Feel the Need For a Well-defined Brand Identity}

Creative teams do not show any type of reticence with respect to brand logics, especially when exposed to the semiotic vocabulary and notions related to brand identity. There was already a strong awareness of the lack of guidelines for the management of the Pininfarina brand, hence the call from the Designers for more stringent and formalized guidelines that they expect the brand identity would provide. Some of the comments were quite explicit in expressing the need for a formalized brand:

"We never had any brand management as such; we relied on the exceptional individuals of the family." (Special projects Director). 
"Today we do not have a branding culture."

"There are obvious organizational issues in managing the brand. Who is supposed to have the best sensitivity to Pininfarina image?" (Deputy Communication Director).

"We all believe in the strength and potential of the brand". (Design Team Leader 3)".

"We have lack a proper discourse on the brand... We need a strong and coherent brand".

"A formalized brand is necessary for the car design teams, but is even more important for the Extra team".

(Vice-Director Business Development for Style and Engineering).

\section{3) The Design Teams Actively Participate to the Process of the Brand Identity Definition}

All of the contributions of designers have been essential in the formalization of the brand identity. They took the opportunity of the project to express their own vision on the brand. Their inputs brought vital contributions not only to the aesthetic dimension as it was expected but also on the ethics invariants.

We have gathered some examples of their input which contributed to the final formalization of the brand identity as can be seen on Figure: 4 which show the synthetic results, positioned on a brand hinge according to Floch's scheme.

"Pininfarina creates the most beautifully proportioned cars."

"Pininfarina has a unique holistic approach."

"Balance, iconic simplicity, elegance, sporty nature" (Head Designer for Special Projects. Design team 2)

"reserved, subdued... Piemontese."

"air..., aerodynamism”.

"Never a casual (or gratuitous) design." (Design Team Leader 3)

"Excellence, a particular relationship with time, Italian, proposing a dream." (Vice-Director Business Development for Style and Engineering).

"Harmonious proportions; cleanliness of the shapes; timelessness."

"It is not cosmetic design"

"Make the object expressive" (Design Team Leader 2)

"We are a luxury brand". (Managing Director)

"Air flow on surface... interfaces with nature... fluency, tension, balance, dynamism, nature, freedom..."

"Technological innovation as an aesthetic opportunity"

"Volumes/proportions... nothing casual or gratuitous... It is the whole which makes sense, not the single factor... geometric consistency..."

"Not only a style, a philosophy."

"Pininfarina, as a mediator, resolves the dialectic between earth and air".

“The Florida II (Figure 3), Pinin's personal car, is the ultimate symbol of Pininfarina philosophy: elegance, innovation, simplicity, refinement and dynamism." (Presentation on 19.1.2007 in occasion of the Mitomacchina exhibition) 


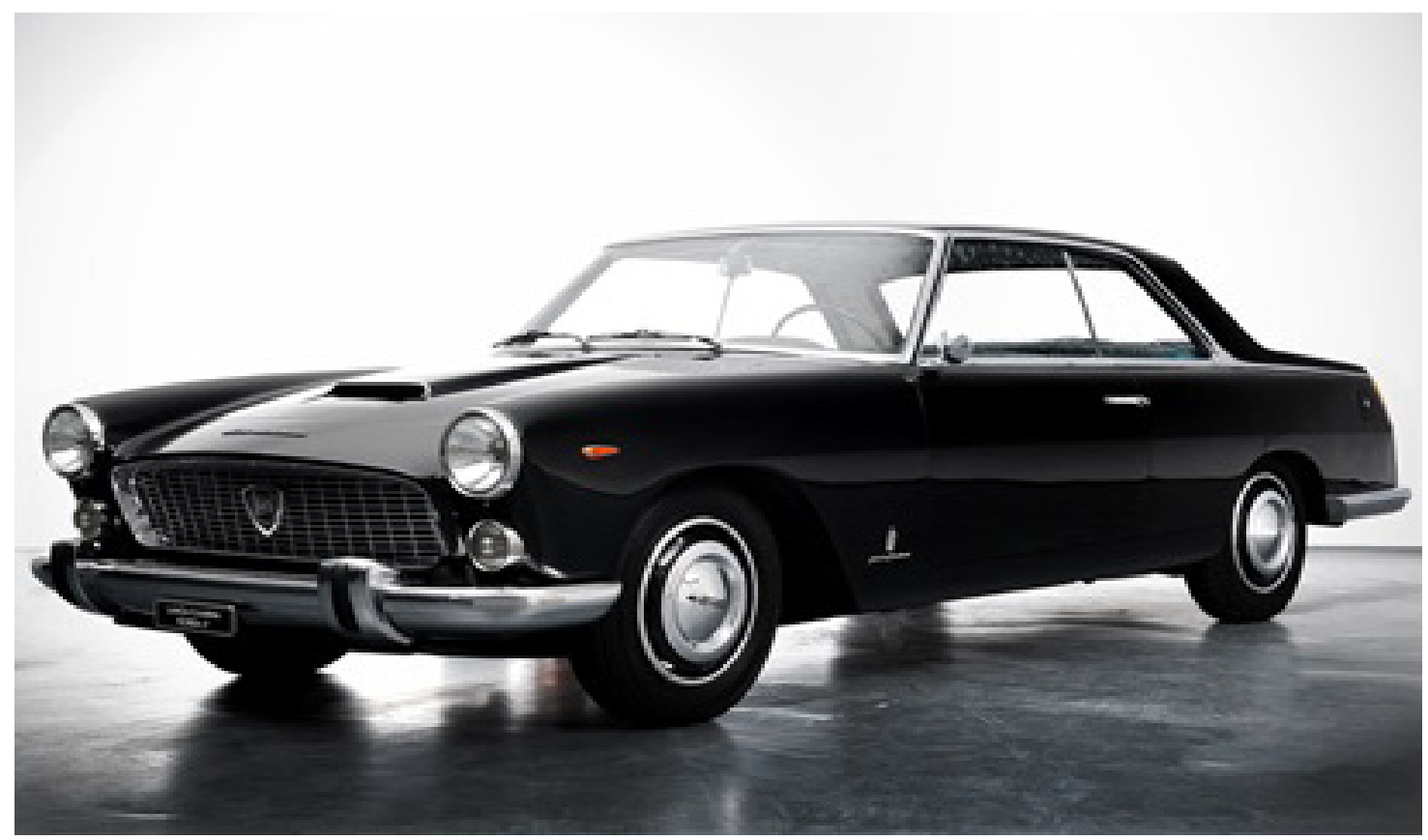

Figure 3. The Lancia Florida II Designed and Built by Pininfarina (1957)

"In this approach, we do not only create consistency in geometry but also in the character and the personality of the cars. And that what brings transparency and honesty in our approach, which keeps Pininfarina's cars current over time."

"Pininfarina's design is both simple and complex at the same time. The complexity is expressed in the volumes distribution, in the harmony of proportions, in the internal geometries of the shape... whereas the simplicity allows for an immediate communication of the car personality." (Design Director)

"Soft lines with tension, round shapes and corners, care in the treatment of surfaces, balance of volumes, innovative texture, dynamism that mean different front and rear view."

"Aerodynamics was and is in the heart of design through the generations"

"Elegance, essentiality, innovation." (PP)

"A perceived lightness" (AP)

"Dynamic, fluid, aerodynamics, lines of strong character, innovation, classicism, universal sporty, elegant, simple."

"Natural union of form and function."

"Always a serious intellectual project, never just aesthetic."

"Thinking forms according to social concern." (Chief Designer 1)

"Aesthetics that lasts; ethics of seriousness."

"We innovate, we find new aesthetic solutions."

"Smooth, classic and strong shapes the right curved surface ${ }^{5}$. the quality of the surface."

"Overcoming the constraints through aesthetics as a solution to technical and financial issues." (Chief Designer 3)

"Strong Piedmonteses culture... absence of a communication culture."

"A serious Piedmonteses engineer, great technical know-how; anti-fashion; very innovative, even if it may not seem to a non-specialist.” External observer (PR of Torino 2008. World design Capital).

"Un monstre sacré"

5 "Il bombato giusto" 
«Designers must be touched by nature genius.” External observer (Direttore dell'Istituto Europeo di Design) Torino

All of the staff interviewed insisted that their profession was the one of a car body-maker ${ }^{6}$, which is why we have included in the ethical invariants, the belief that Pininfarina is the ultimate car body-maker. From being a factual status, it becomes a value of the brand, a commitment applied to all creative and decision-making activities.

The comments and indications given by the interviewees were discussed in groups. The ultimate rationalization was prepared by the consulting team.

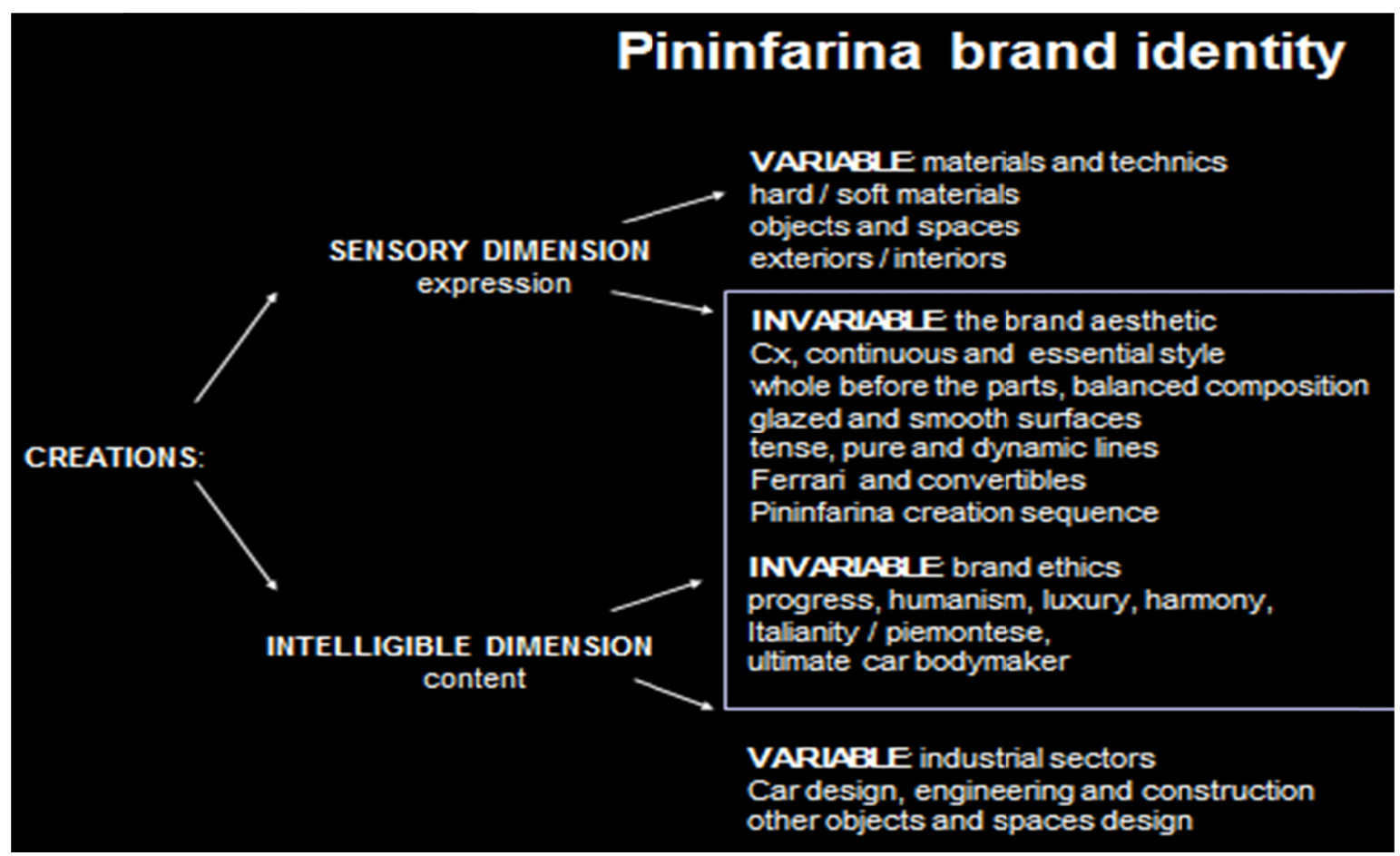

Figure 4. Pininfarina's Brand Identity Expressed According to Floch's Hinge

Another determining source of the brand identity has been the biography of Battista (Pinin) Farina, (1968). This document which had been somewhat forgotten if not never read by most of the designers, was welcomed as a fundamental basis for the brand aesthetics as it clearly characterized the founder's purpose. Battista declares:

"In my work in these times I thought about the line of the wind. Going in winter in the mountains I could see how the wind was shaping the snow at the edge of the road, sculpting either curved or sharp shapes... I wanted to copy those lines for my projects." (Page: 201).

"It was necessary to use new forms maybe copying from nature which is always modern and relevant; see the shapes of the birds, the beautiful profiles of certain fish, and also of certain fantastic insects." (Page: 55).

"I went often to the banks of the Po to observe the beautiful boats, their profile that never changes that I was seeing always as new in its slender simplicity." (Page: 33).

"I liked the cars with simple lines, sober, rather than with rich ornaments, artistic intentions." (Page: 23).

These statements allowed us to establish clearly what was to be called "The air connivance" (See Figure: 5) as the major organizing principles of the brand aesthetics which was subsequently used in the definition of the future mon-branded products and services.

Concluding on this third essential finding, we can also sustain that, beyond the obvious benefits of a strongly desired formalized Pininfarina brand identity that will be developed in the implication parts, the sheer participation of the design teams into the process of the brand identity definition has contributed greatly to the tension reduction among them. As it often happens, the process of participation of the protagonists acquires as much importance as the results themselves.

\footnotetext{
6 "Siamo carrozziere"
} 


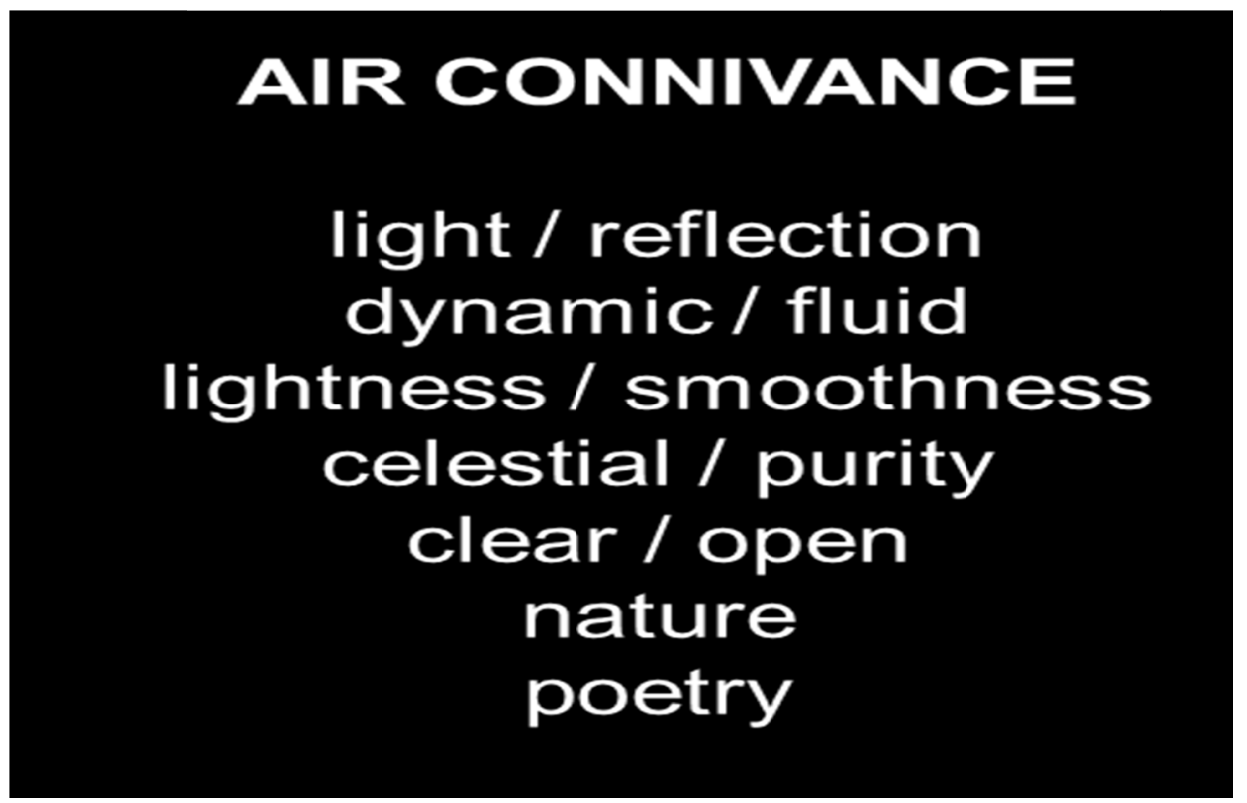

Figure 5. "Air Connivance" as the Organizing Principles of the Design of the Mono-branded Products

\section{4) The President's Attitude and Involvement has been Essential for the Success of Project}

By explaining the strategic importance of the project and showing his strong personal commitment, AP contributed to the Designers' motivation. The Pininfarina brand project was launched by AP in a formal meeting. In all occasions, he demonstrated how crucial the project was for the company's future. For instance, in a company monthly Design meeting, AP declared: "If we look at the 40 design projects we carried out in 2006, it appears clearly that we have to strive for a more integrated designs. Our own "writing" should be felt in all our creations. The brand definition project should not only help in developing our own mono-branded products but also give us clear guidelines in all our design works for other brands."

\section{5) Tensions Among the Design Teams are Resolved or at Least Reduced by the Brand Identity Definition} Process and Results

Strong evidence of tension reductions came in when we started using the results of the initial phase of the project. The Brand Identity definition was somewhat "institutionalized" after having been presented and accepted by the Board of Directors. Each Designer directly participated to the Brand Identity elaboration and could recognize his own contribution in the final version. The process gave a strong legitimacy to the results of the project and all participants felt committed to it.

The Brand Identity hinge was then developed into a diagnostic tool (the ESTET diagram, see Figures: 6 and 7) allowing for the measure of the degree of consistency of specific brand manifestations with the ethics and aesthetics invariants. It is a simple diagram made of two axes measuring the degree of consistency of a specific brand manifestation respectively with the aesthetic and ethic invariants. We organized several meetings with the design teams in order to make a judgement of coherence of the designs of past cars and objects with respect to the defined Brand Identity. All the Design teams agreed on the final results presented in Figures 6 and 7, demonstrating a capacity to work jointly and discuss rationally on aesthetics and ethics considerations on Pininfarina's designs. The process was applied also to the advertising, logos, etc. 


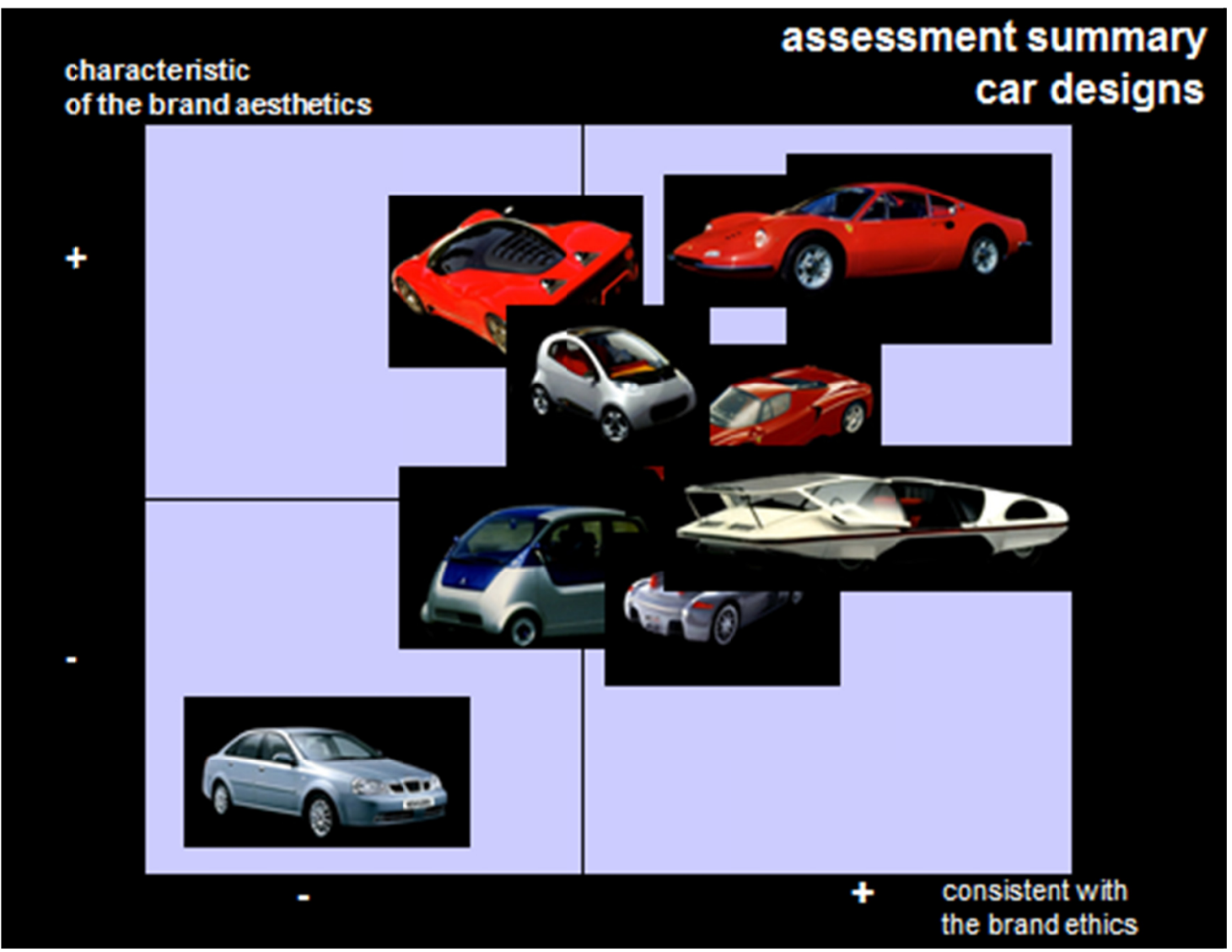

Figure 6. Evaluation of the Consistency of Various Historical Automotive Designs in Terms of Ethics and Aesthetics

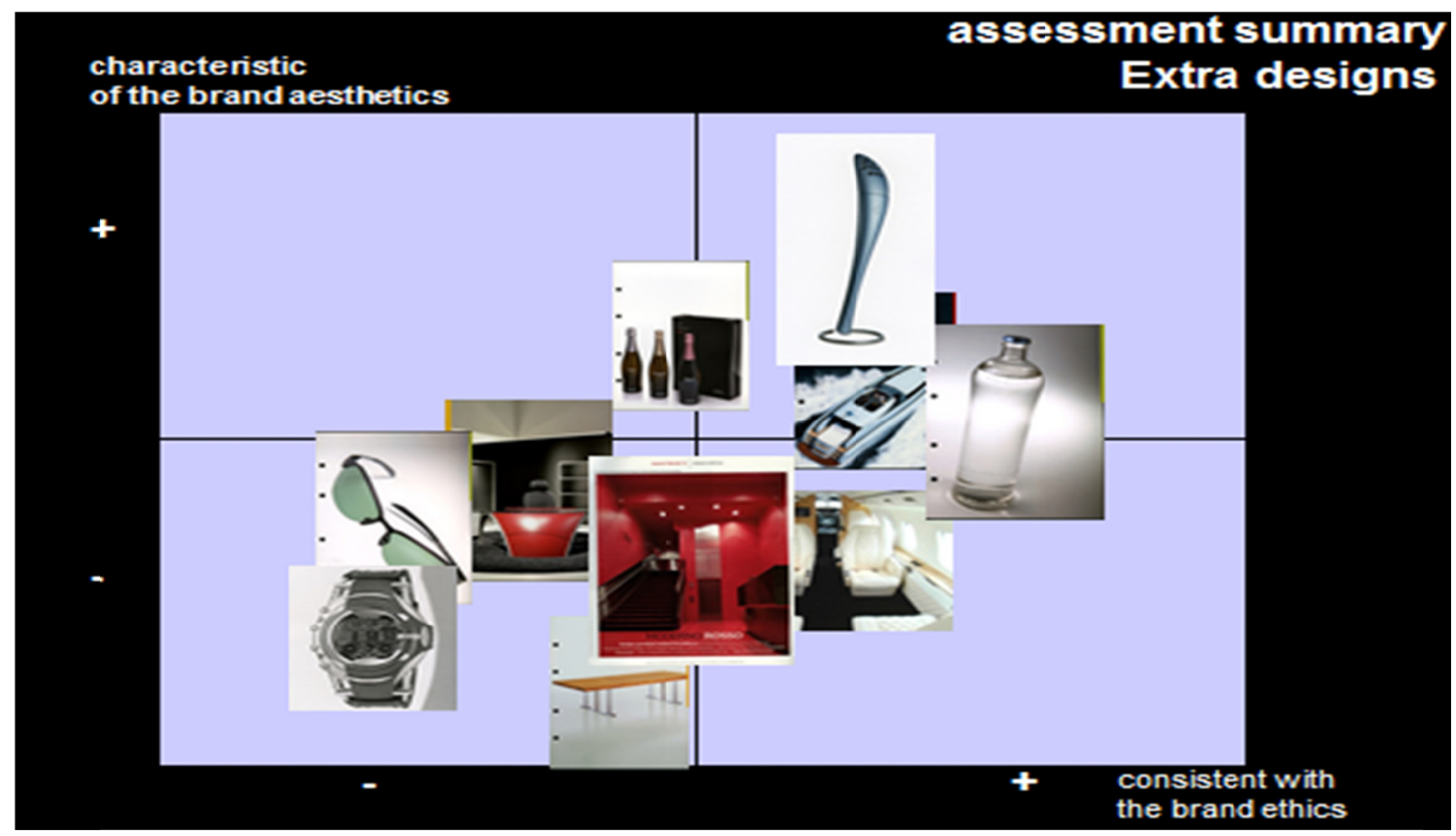

Figures 7. Evaluation of the Consistency of Various Historical Extra Objects Designs in Terms of Ethics and Aesthetics 3.1 Practical Implications

In addition to having demonstrated the usefulness of a clearly defined brand identity in appeased interrelationships among creative departments. The following tools and methodologies were developed:

A semiotic-based methodology to formalize a possible brand identity.

A diagnostic tool to measure the degree of coherence of any brand manifestation with respect to the ethic and aesthetic 
dimensions of a pursued brand identity (the EST-ET diagram).

\subsection{At Pininfarina's Level, There are Strategic and Operational Implications:}

The identity of the possible Pininfarina's brand has been defined in terms of ethics and aesthetics invariants.

The brand identity elements which came out of the formalization process have been integrated into the company communication and the creation of the concept car "Sintesi" (See Figure 8) and the electrical car (Bluecar) developed with the Bolloré Group's batteries. They serve as basic guidelines for all future projects.
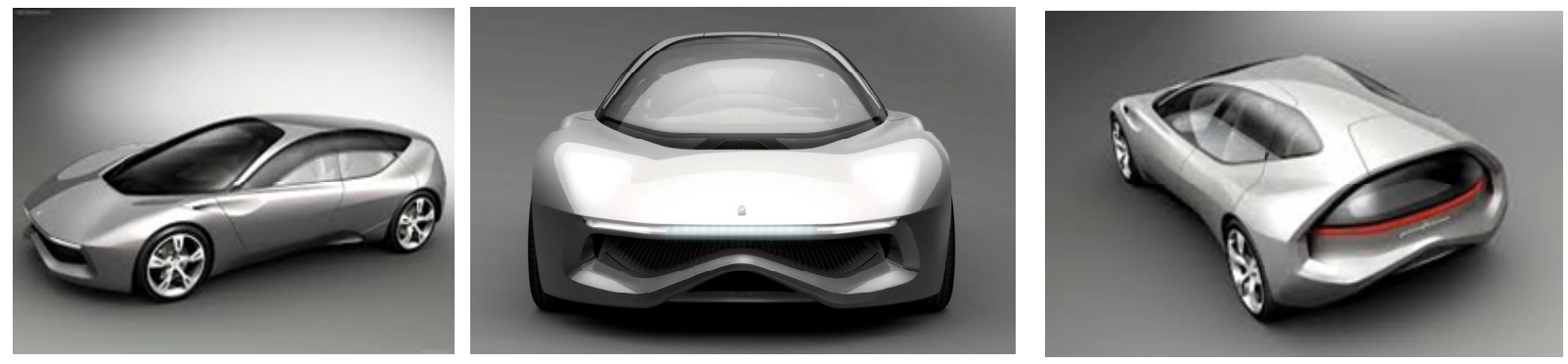

Figure 8. Pininfarina "Sintesi" Concept Car, (2008)

The Brand Identity study led to the development of a detailed possible brand universe which served as a basis to the strategic development plan of the new Pininfarina brand activities (product and service categories). See Figure 9.

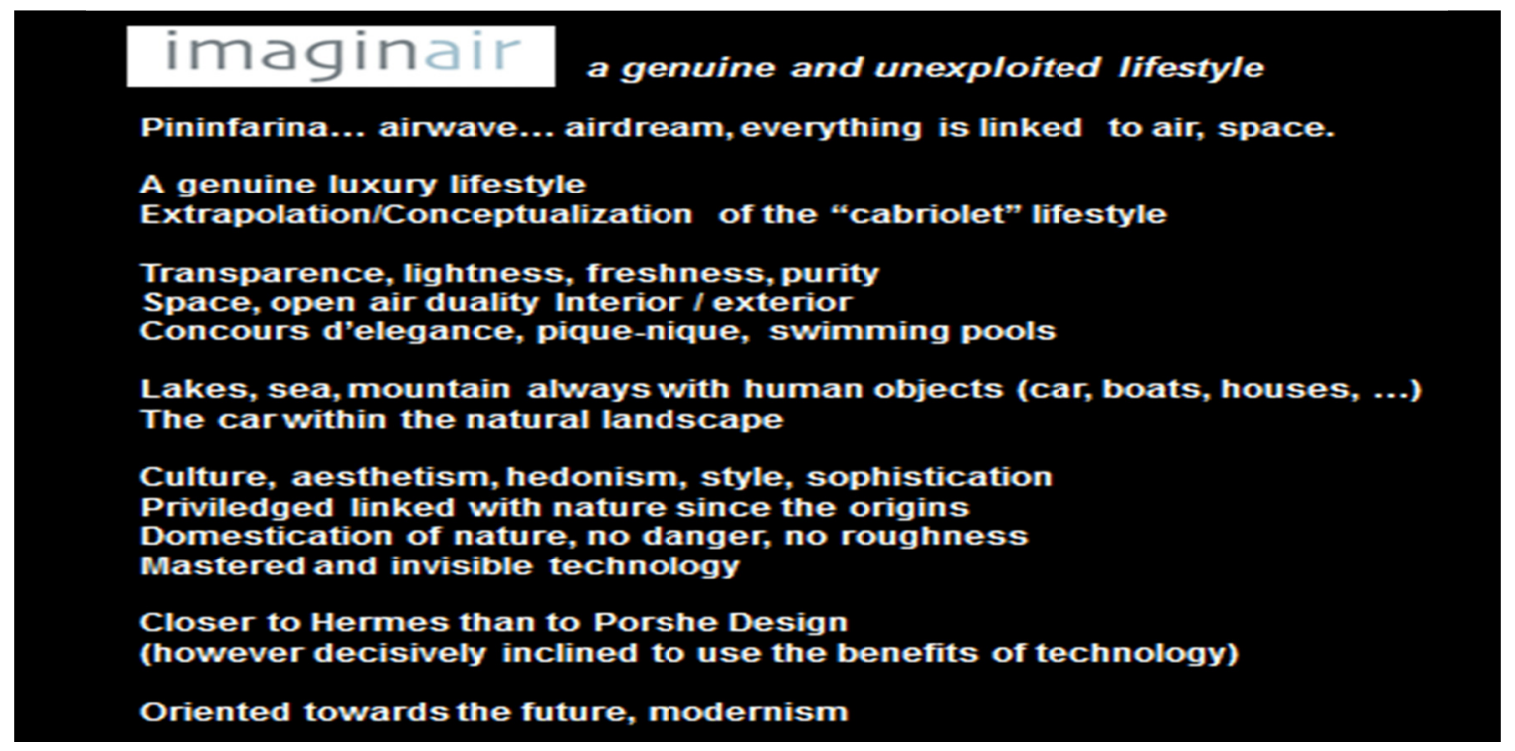

Figure 9. Pininfarina Brand Universe: Imaginair

These Pininfarina implications can possibly be inferred to similar cases of transformation from B2B designer to B2C brand.

\section{Limitations}

This research paper has all the limits of case studies (Flyvbjerg, 2006; Hodkinson \& Hodkinson, 2001):

The complexity of the reality observed is necessarily oversimplified by the analytical schemes applied. The notion of brand identity, for example, cannot grasp all of the wealth of defining characteristics of a brand.

The lessons derived from the study are not necessarily generalizable to other cases, the context being unique and irreproducible.

The enormous amount of data available has been a source of analytical difficulties. The 80 years of well-documented Pininfarina's car designs and communication required making choices on what looked to us as the most meaningful. We were also limited by the 3 month time framework of the project.

Moreover, we have chosen the notion of brand identity rather than brand personality in order to create a managing instrument to offer guidelines all persons who would promote the brand through creation and communication. The 2 approaches are currently used by academics and practitioners. Along with Azoulay \& Kapferer, (2003), who write: "Brand personality is a useful concept, but brand identity has more facets than 
the personality facet alone." we believe that the notion of identity is richer and more rigorous especially in its semiotic approach.

\section{Originality/Values}

There are no documented examples of the passage from B2B designer to B2C Company. This has been a unique opportunity to be called by one of the greatest car designer, in order to help in this transition. We had this rare chance of grounding our study in an actual ground reality, revealing all the complexity of design projects and helping us in understanding the complex inter-relationships of design teams.

Furthermore, this study has proven that in a case of inter-departments tensions, participation to common projects may help in their resolution. However, two conditions seem indispensable:

The top Management support to the project is fundamental.

The department teams need to be convinced of the usefulness of the project results.

This has also been a unique opportunity to apply to its fullest extent a semiotic approach to brand definition and management. The results have been presented up to the board level and accepted (and used) by the staff and executives in communication and design. The process has also confirmed the validity of the ESTET diagram as a diagnostic tool of coherence of brand manifestations with respect to brand identities.

\section{Conclusion}

One axis of further research would be return to the same company a few years later and observe whether the consensus built during the common project lasted over time.

Comparisons with similar common projects in different fields as strategy, organization, and diversification could also be fruitful in our understanding of the processes of attitudes changes in corporate environment.

As for Pininfarina Company, the case study had a major direct and lasting impact on the management. It served as a guideline to all the company development and communication activities. The most spectacular has been the concept car "Sintesi" presented at the Geneva car show in 2008. The project had been conceived by the Chief Designer and AP to present and respect all the factors of the Pininfarina's brand identity as formalized by the study.

The website (accessed on October $24^{\text {th }} 2014$ ) language shows also that the results of the work done on the brand identity are present in the brand communication. We can read for instance that: "Pininfarina DNA today is the same as in the thirties: the centrality of the design, the aesthetic sensibility capable of creating timeless beauty, the constant striving for innovation, the strength of a tradition that brings together industry, technology, and stylistic research, the ability to interpret the client's needs without altering the brand identity."

Since Andrea Pininfarina's death on August 7th 2008 in a Vespa accident, the brand development project has been held, waiting for new investors to restructure the group and mobilize the necessary financial resources to launch the implementation of the brand in terms of mono-branded products and services.

\section{Acknowledgments}

We are grateful to the late Andrea Pininfarina who was the enthusiastic initiator of the project and his brother Paolo who is now the President of the company.

The Design Director Lowie Veermersch was an essential contributor to the final results of the project as well as a key motivator of the design teams. Special thanks to Jean-Christophe Villain, the Design specialist of the consulting team without him the project could not have prospered.

\section{References}

Aaker, D. A. (1996). Building Strong Brands. New York: The Free Press.

Azoulay, A., \& Kapferer, J. F. (2003). Do Brand Personality Scales Really Measure Brand Personality? Brand Management, 11(2), 143-155. http://dx.doi.org/10.1057/palgrave.bm.2540162

Burmann, C., Jost-Benz, M., \& Riley, N. (3009). Towards an Identity-based Brand Equity Model. Journal of Business Research, 62, 390-397. http://dx.doi.org/10.1016/j.jbusres.2008.06.009

Chevalier, M., \& Mazzalovo, G. (2004). Pro Logo: Brands as a Factor of Progress. UK: Palgrave MacMillan.

Chevalier, M., \& Mazzalovo, G. (2012). Luxury Brand Management. Singapore, Wiley \& Sons (second edition). http://dx.doi.org/10.1002/9781119199168

\footnotetext{
${ }^{7}$ Understood here as "brand identity invariants"
} 
Chiapello, E. (1998). Artistes versus Managers. Paris : Editions Métaillé.

Coquet, J. C. (1982). Sémiotique: L'Ecole de Paris. Paris : Hachette Université.

De Chernatony, L. (2006). From Brand Vision to Brand Evaluation. The Strategic Process of Growing and Strengthening Brands. 2ed. Oxford: Butterworth-Heinemann.

Dion, D., \& De Boissieu, E. (2013). Construction et mise en scène d'un lignage : le cas des chefs dans la haute cuisine. Décision Marketing, 70. http://dx.doi.org/10.7193/dm.070.25.42

Eisenhardt, K. M. (1989). Building Theories from Case Study Research. Academy of Management Review, 14(4).

Floch, J. M. (1990). Sémiotique, Marketing et Communication. Sous les signes, les stratégies. Paris: Presses Universitaires de France.

Floch, J. M. (1995). Identités visuelles. Paris : Presses Universitaires de France.

Flyvbjerg, B. (2006). Five Misunderstandings about Case-Study Research. Qualitative Enquiry, 12(2). http://dx.doi.org/10.1177/1077800405284363

Groupe, U. (1992). Traite du Signe Visuel : Pour une Réthorique de l'Image. Paris: Seuil.

Heilbrunn, B. (2000). La Marque : Métaphore Vive Ou Métaphore Vide ? Conférence Le tendenze del Marketing in Euopa. Università Ca'Foscari. Venezia..

Hjelmslev, L. (1971). Essais linguistiques. Paris : Editions de Minuit.

Hodkinson, P., \& Hodkinson, H. (2001). The Strengths and Limitations of Case Study Research. Paper presented to the Learning and Skills Development Agency conference" Making an Impact on Policy and Practice". [online] Cambridge, 5-7 December 2001. http://education.exeter.ac.uk/tlc/docs/publications/LE_PH_PUB_05.12.01.rtf [accessed 22 October 2014].

Janson, H. W. (1995) History of Art. 5th edition. Revised and expanded by Anthony F. Janson. London: Thames \& Hudson

Johansson, U., \& Holm, L. S. (2006). Brand Management and Design Management. In: Brand culture by Schroeder J. and Salzer-Moerling M. New York: Routledge.

Kapferer, J. N. (1992). Strategic Brand Management: New Approaches to Creating and Evaluating Brand Equity. London: Kogan Page.

Koch, C. H. (2014). Corporate Brand Positioning: Case Studies across Firm Levels and Over Time. Lund University, School of Economics and Management.

Langley, A. (2011). Studying Process In and Around Organizations. In D.Buchanan, \& A.Bryman (Eds.). The Sage handbook of organizational research methods. London, UK: Sage publications.

Lendrevie, J., Levy, J., \& Lindon D. (2009). Mercator : Théories et nouvelles pratiques du Marketing. Paris: Dunod.

Mazzalovo, G. (2012). Brand Aesthetics. London: Palgrave Macmillan. http://dx.doi.org/10.1057/9781137025609

Mazzalovo, G., \& Darpy, D. (2014). Gestion Expressive des Marques dans un Contexte de Baroquisation. Décisions Marketing, DM 74, 83 - 96.

Michlewski, K. (2008). Uncovering Design Attitude: Inside the Culture of Designers. Organization Studies, 29 (3), 373-392. http://dx.doi.org/10.1177/0170840607088019

Monga, A. B., \& John, D. R. (2010). What Makes Brands Elastic? The Influence of Brand Concept and Styles of Thinking on Brand Extension Evaluation. Journal of Marketing, 74(3), 80-92. http://dx.doi.org/10.1509/jmkg.74.3.80

Moore, C. M., Fernie, J., \& Burt, S. (2000). Brands without boundaries. The internationalization of the designer retailer's brand. European Journal of Marketing, 34(8), 919-936. http://dx.doi.org/10.1108/03090560010331414

O’Shaughnessy, J. (1987). Why People Buy. Oxford: University Press.

Pininfarina, B. (1968). Pininfarina. Nato con l'Automobile. Memorie raccolte da Ernesto Caballo. Milano: Palazzi Editore.

Ricœur, P. (1990). Soi-même comme un autre. Paris : Editions du Seuil.

Saussure de, F. [1916 (2005)]. Cours de linguistique générale. Paris : Payot. 
Semprini, A. (1997). Le Marketing de la marque. Paris : Editions Liaisons..

Semprini, A. (2005). La marque, une puissance fragile. Paris: Vuibert.

Stern, I., \& Henderson, D. A. (2004). Within Business Diversification in Technology Intensive Industries. Strategic Management Journal, 25(5), 487-505. http://dx.doi.org/10.1002/smj.400

Upshaw, L. B. (1995). Building Brand Identity: a Strategy for Success in a Hostile Market Place. New York: John Wiley \& Sons.

Van De Ven, A. H. (2007). Engaged Scholarship. A Guide for Organizational and Social Research. Oxford, Oxford University Press.

This work is licensed under a Creative Commons Attribution 3.0 License. 